\title{
Performance Indicators
}

for

1st Quarter CY 1993
AEC..,

Ros $10:$

C...

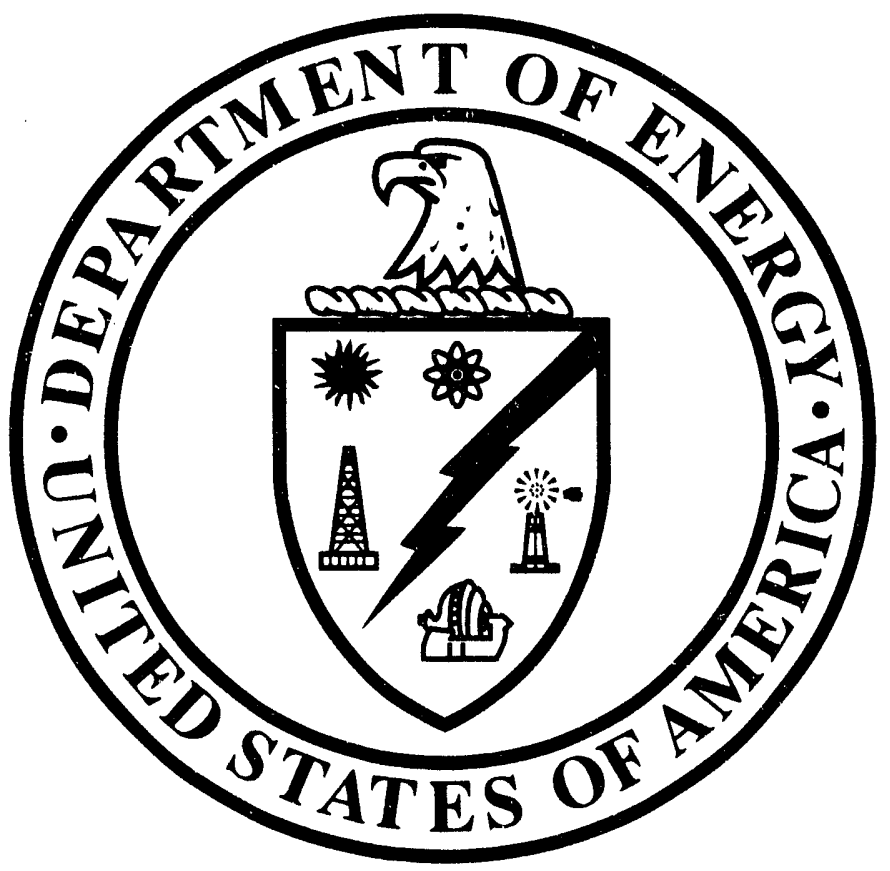

EG\&G Idaho, Inc.

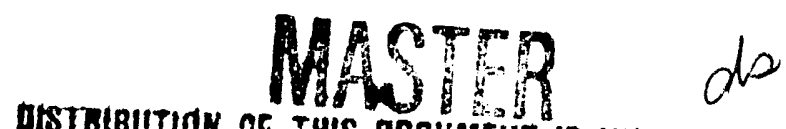




\section{CONTENTS}

Acronyms

1. Management Summary …................................................ $\quad 1-1$

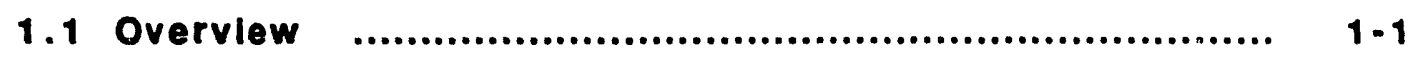

1.2 Performance Inltlatives ............................................... 1 1-5

1.3 Good Practices ........................................................ 1.5

2. Overview by Performance Indicator ................................... 2.1

2.1 Performance Indicators ................................................. 2.3

2.2 Root Causes...................................................... $2-23$

\section{APPENDICES}
A. Summary of Performance by Performance Indicator
$A-1$
B. Performance Indicator Charts for the ATR Faclilty.
B.1
C. Performance Indicator Charts for the RWMC Facility.
C.1
D. Performance Indicator Charts for the WERF Facllity.
D.1
E. Performance Indicator Charts for the TRA Hot Cells Facillty...
E-1
F. Performance Indicator Summary
F-1
G. Performance Indicator Definitions
G.1 


\section{ACRONYMS}

\begin{tabular}{|c|c|}
\hline ALARA & As Low As Reasonably Achievable \\
\hline ARMF & Advanced Reactivity Measurements Facility \\
\hline ATR & Advanced Test Reactor \\
\hline ATRC & Advanced Test Reactor Critical (facility) \\
\hline CAM & Continuous Air Monitor \\
\hline CFRMF & Coupled Fast Reactivity Measurement Facility \\
\hline Cin & Corrective Maintenance \\
\hline CTS & Commitment Tracking System \\
\hline CY & Calendar Year \\
\hline DOE & Department of Energy \\
\hline DOE-ID & Department of Energy Field Office, Idaho \\
\hline ER\&WM & Environmental Restoration and Waste Management \\
\hline ES\&H & Environment, Safety, and Health \\
\hline FY & Fiscal Year \\
\hline HQ & Department of Energy, Headquarters \\
\hline LLW & Low Level Waste \\
\hline NE-1 & Assistant Secretary for Nuclear Energy \\
\hline NPDES & National Pollutant Discharge Elimination System \\
\hline OR & Occurrence Report \\
\hline ORR & Operational Readiness Review \\
\hline OSHA & Occupational Safety and Health Act \\
\hline OSR & Operational Safety Review \\
\hline PI & Performance Indivator \\
\hline PM & Preventive Maintenance \\
\hline PSO & Program Secretary Office \\
\hline RWMC & Radioactive Waste Management Complex \\
\hline SEN & Secretary of Energy Notice \\
\hline SAR & Safety Analysis Report \\
\hline SARA & Superfund Amendments and Reauthorization Act of 1986 \\
\hline SDA & Subsurface Disposal Area \\
\hline TLD & Thermoluminescent Dosimeter \\
\hline TRA & Test Fieactor Area \\
\hline UOR & Unusual Occurrence Report \\
\hline WACCC & Waste Acceptance Criteria Certification Committee \\
\hline WERF & Waste Experimental Reduction Facility \\
\hline WIPP & Waste Isolation Pilot Plant \\
\hline
\end{tabular}




\section{MANAGEMENT SUMMARY}

\section{Introduction}

The Department of Energy (DOE) has established a Department-wide Performance Indicator (PI) Program for trending and analysis of operational data as directed by DOE Order 5480.26. The PI Program was established to provide a means for monitoring the environment, safety, and health (ES\&H) performance of the DOE at the Secretary and other management levels. This is the ninth in a series of quarterly reports generated for the Department of Energy Field Office, Idaho (DOE-ID) by EG\&G Idaho, Inc. to meet the requirements of the PI Program as directed by the DOE Standard (DOE-STD-1048-92).

"It is important to recognize the diverse nature of the types, missions, and staffing levels of the facilities participating in the DOE Performance Indicator Program. Because of these differences, direct comparison of the facilities and their PI values is not appropriate and may lead to erroneous or suspect judgments regarding performance." (DOE Pefformance Indicators Guidance Document, DOE-STD-1048-92, December, 1992, page 1)

\subsection{Overview}

The information in this ninth quarterly repont, while contributing to a historical database for supporting future trending analysis, does not at this time provide a sound basis for developing trend-related conclusions. In the future, it is expected that trending and analysis of operational data will enhance the safety culture in both DOE and contractor organizations by providing an early warning of deteriorating environmental, safety, and health conditions.

DOE-STD-1048-92 identifies four general areas of PIs. They are:

- Personnel Safety

- Operational Incidents

- Environment

Management

These four areas have been subdivided into 26 performance indicators. Approximately 115 performance indicator contrnl and distribution charts comprise the body of this report A brief summary of Pls contained in each of these general areas is provided in the following pages.

The four EG\&G facilities whose performance is charted herein are as follows:

1. The Advanced Test Reactor (ATR)

2. The Radioactive Waste Management Complex (RWMC)

3. The Waste Experimental Reduction Facility (WERF)

4. The Test Reactor Area (TRA) Hot Cells

During the first quarter of 1993, the Critical Facilities [the Advanced Reactivity Measurements Facility (ARMF), the Coupled Fast Reactivity Measurements Facility (CFRMF), and the Advanced Test Reactor Critical facility (ATRC)] received DOE and PSO (NE) concurrence that reporting under the PI Program was no longer required.

EG\&G underwent a Tiger Team review during the fourth quarter of CY 1991, however, issues identified during the review were not reported for either the fourth quarter of 1991 or the first quarter of 1992 for PI 
4.1. The Tiger Team report was finalized during the second quarter of 1992 and the findings that still remain open are contained in this report.

For the performance indicator control charts included in this report, a diamond shape is used to denote the reported value. However, for those indicators with an observed value of zero during the reporting period, only half of the diamond symbol is visible.

Central lines $\bar{x}$, (i.e., average (mean) of all data) and upper and lower control limits (UCL and $L C L$, respectively) are calculated for the control charts for those indicators as directed by DOE-STD-1048-92. For those indicators whose LCL is less than zero, the limit is not shown on the chart.

\section{- Facility Status}

The Advanced Test Reactor (ATR) continued its mission of test material irradiations and isotope production during the reporting period at an approximate $65 \%, 71 \%$, and $54 \%$ equivalent availability for the months of January, February, and March respectively.

The Test Reactor Area (TRA) Hot Cells continued operation on a limited basis for processing Iridium from the ATR.

The Radioactive Waste Management Complex (RWMC) was fully operational during the first quarter of 1993.

The Waste Experimental Reduction Facility (WERF) is currently in a shutdown condition, and has been since February 1991. Activities at the WERF are limited to those required for safe receipt and storage of low-level radioactive waste (LLW) for future processing and tasks associated with restarting the facility. The WERF will not be ready for operational startup until all safety, health, and environmental concerns have been addressed to the satisfaction of the Department of Energy. Currently restart project personnel are rewriting procedures and attending to work control and maintenance backlog issues. The restart activity is expected to be completed early in the second quarter of 1993. Pending the successful conclusion of operational readiness inspections, WERF is expected to restart operations no later than the fourth quarter of 1993.

\section{- Personnel Safety}

Both shallow and deep radiation dose exposures show an decrease attributed to the types and quantity of outage work at the ATR during the first quarter of 1993. The radiation exposures at all facilities remain well within the 1993 ALARA goals.

Only a single skin/clothing contamination event occurred during the firs? quarter of 1993 at the EG\&G facilities. The event occurred at the TRA Hot Cells and was attributable to inadequate procedures resulting in several particles being picked up on a worker's company furnished clothes during the discharge of a sample from the Hot Cells (ID--EGG-TRAHC-1993-0002). The relatively low number of skin contamination events is reflective of the increased EG\&G radiological control activities.

There have been no radioactive or hazardous material overexposures at any of the EG\&G facilities during the nine quarters of the PI program.

Although eighteen lost work day events occurred at EG\&G facilities during the first quarter of 1993, the lost work day case rate dropped from 1.72 events/100 person years in the sourth quarter of 1992 to 1.58 events/100 person years in the first quarter of 1993. This compares to an average lost time accident rate (including lost and restricted work days) of 1.7 for the DOE system ${ }^{\mathrm{a}}$, and 4.1 for U.S. industry regulated by

a. Source: Occupational Injury and Property Damage Summary Report, January - December 1992, Office of Safety and Quality Assurance. 
OSHA ${ }^{b}$. The majority of these events are strains $(65 \%)$ and cumulative trauma disorders (12\%). The EG\&G goal for the lost work day case rate for FY-93 is 1.29 events/100 person years.

Although 43 injury/illness cases occurred at EG\&G facilities during the first quarter of 1993, the injury/iliness rate dropped from 4.16 events/100 person years in the fourth quarter of 1992 to 3.77 events/100 person years in the first quarter of 1993. This compares to an average injury/illness rate of 3.7 for the DOE system, and 8.8 for U.S. industry regulated by OSHA. The majority of these cases are strains $(36 \%)$ and cumulative trauma disorders $(29 \%)$. The EG\&G goal for the recordable injury/illness rate is 3.18 events/100 person years.

\section{- Operational Incidents}

There were no unplanned safety function actuations at any of the EG\&G facilities during the first quarter of 1993.

The number of violations of operating procedures increased from two events in each of the four previous quarters to three violations at the EG\&G facilities in the first quarter of 1993. All three violations occurred at the ATR and involved 1) the improper mounting of an experimental loop pump base (ID--EGG-ATR-19930004); 2) a failure to fully understand and perform a loop shutdown test (ID--EGG-ATR-1993-0008); and 3) the inadvertent removal of a check source (ID--EGG-ATR-1993-0009). The increase from two to three violations is not significant and can not be attributed to any generic cause.

The number of unplanned shutdowns at EG\&G facilities remained at three for the first quarter of 1993. All three of the first quarter unplanned shutdowns occurred at the ATR with two of the three reactor shutdowns resulting from equipment failures. One of the equipment failures was a manually initiated shutdown of the ATR when the reactor control cylinders failed to function normally (ID--EGG-ATR-19930006) and was also reported as an Unusual Occurrence (PI 2.4). The other equipment failure involved the failure of an experimental loop instrument (ID--EGG-ATR-1993-0005). The third ATR outage was a reactor scram initiated from an experimental loop as a result of an operator error due to a training deficiency (ID-. EG\&G-1993-0001).

A single Unusual Occurrence Report (UOR) was issued by the EG\&G facilities during the first quarter of 1993. The single UOR was the result of an equipment failure which necessitated a manual shutdown of the ATR when the reactor control cylinders failed to function normally (ID--EGG-ATR-1993-0006). This was also reported as an unplanned shutdown (PI 2.3).

No substance abuse incidents occurred at EG\&G during the first quarter of 1993.

\section{- Environment}

The majority of the airborne effluent is from the ATR nuclear fission reactor and is due to the activated argon-41 in the low pressure, low temperature primary coolant system water. The activated argon has a short half-life of 1.82 hours. An ATR design change in process will delay the release of argon allowing a substantial amount to decay before being released. Even though the ATR experienced increased megawatt-day production (power and on-stream time), the slightly lower releases during the first quarter of CY 1993 ware due to the previous higher releases due to a pinhole leak in the cladding of a fuel element in Cycle 98B 1 during the fourth quarter of 1992.

The liquid radioactive effluent release is from the ATR nuclear fission reactor and is due to the tritium $(96 \%)$ in the primary coolant system water. The tritium levels are expected to continue to increase due to the beryllium reflector continuing its predicted aging and cracking. The higher releases during the first quarter of CY 1993 were due to increased megawatt-day production (power and on-stream time).

No airborne or liquid hazardous substances or regulated pollutants were released by any of the EG\&G facilities during the first quarter of 1993.

b. Source: National Safety Council, The Accident Facts, 1992 edition. 


\section{1st Quarter CY93}

No environmental incidents occurred at any of the EG\&G facilities during the first quarter of 1993.

The amount of low level radioactive waste generated in this reporting period decreased primarily due to concentrated efforts during the fourth quarter of 1992 by the ATR to collect, characterize, and ship waste from various ATR accumulation areas. In addition, the fourth quarter of 1992 also contained the low level radioactive waste that was generated by RWMC due to decontamination activities at the Certified and Segregated Waste Storage Building. The low level hazardous waste that was generated in the first quarter of CY 1993 was three industrial lead acid batteries from the RWMC that were returned for recycling. No mixed waste was generated at any of the EG\&G facilities during the first quarter of 1993.

\section{- Management}

The DOE Audit Issue PI was previously defined as a facility total of the number of open DOE Audit Issues at the end of the quarter. It is now defined as a contractor total of the number of DOE Audit Issues that have been open greater than 90 days at the end of the quarter. It was not possible to backfit data for this indicator as the information has been kept at the facilities and only as the number of issues open rather than the number of issues open greater than 90 days. Therefore, data are only presented in this report for first quarter 1993. A total of 199 contractor issues had been open greater than 90 days at the end of the first quarter.

Two open external organization recommendations were identified at RWMC during the Waste Isolation Pilot Plant (WIPP) audits by the Waste Acceptance Criteria Certification Committee (WACCC) in the third quarter of 1991. This PI was previously a facility total of the number of open External Organization Issues at the end of the quarter. It is now a contractor total of the number of External Organization Issues that have been open greater than 90 days at the end of the quarter. No additional issues were identified when this indicator became a contractor total.

The definition for the OSH Noncompliance PI was changed from the number of OSH violations identified at the facilities during the quarter to the number of $\mathrm{OSH}$ noncompliances open greater than 90 days for the contractor at the end of the quarter. It was not possible to backfit this indicator as the information has been kept at the facilities and only as the number of issues identified duririg the current quarter rather than the number of issues open greater than 90 days. Additionally, no company level system exists to track the information as currently required. Therefore, reporting for this indicator will continue to be a facility total until such time as a system is in place to track these issues at a company level. It is currently planned to have a tracking system in place and functional by the first quarter of 1994. For first quarter 1993, 131 issues remained open greater than 90 days at the end of the quarter.

During the fourth quarter of 1992 at EG\&G facilities, there were 142 CM items open greater than three months versus a total of 413 open (34\%). For the first quarter of 1993, the total number of open items increased to 423 , with $237 \mathrm{CM}$ items open longer than three months $(56 \%)$. The corrective maintenance backlog increased during the first quarter of 1993 because the ATR assigned priority work towards the preparation for the Process Control Upgrade outage scheduled for the second quarter of 1993.

During the fourth quarter of 1992 at EG\&G facilities, 3.04\% of the scheduled PM items were not completed within the originally scheduled interval (25 of 822 ). For the first quarter of $1993,4.05 \%$ of the scheduled PM items were not completed within the originally scheduled interval (24 of 592).

At the close of the first quarter, 24 Final Occurrence Reports (ORs) had open corrective acticns at EG\&G facilities (ATR-14, RWMC-6, and WERF-4). The increased number of occurrence reports reflects the increased emphasis on finalizing ORs. 


\section{- Conclusions}

The overall evaluation of the performance indicators continues to indicate proactive performance. Deficiencies are being worked off in accordance with an established priority system. Incomplete corrective and preventive maintenance activities are being reviewed, and their effect on equipment and operations is evaluated and resolved at the proper management level.

\subsection{Performance Initiatives}

As of the first quarter CY 1993 reporting period, emphasis is still being placed on establishing administrative systems and processes for implementing the DOE Order 5480.26 quarterly reporting requirements. As a performance initiative, the EG\&G Power Reactor Programs Department continues to work on strengthening all radiation contamination controls at their participating facilities, specifically the TRA Hot Cells in preparation for a full restart in FY 1993. The reduction for the past three quarters in the number of contaminations reported by the TRA Hot Cells for PI 1.2, Skin Contaminations, is at least partially attributable to these efforts.

A Corrective Action Team was formed at the RWMC to develop and evaluate a system for priority-based scheduling. Weekly planning meetings will be upgraded to achieve priority-based scheduling. These efforts are directed at improving the corrective and preventive maintenance, OSH deficiency correction, and the Occurrence Report corrective action processes.

\subsection{Geod Practices}

As stated above, this program is new and a limited database has been established. Trends are still developing, but appropriate actions are being taken on the initial trends.

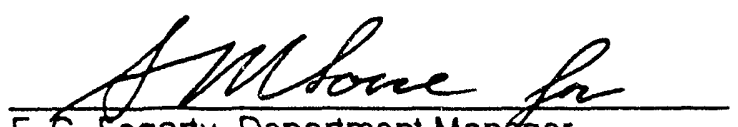

F. C. Fogarty, Department Mankger

Power Reactor Programs

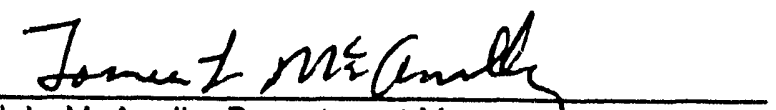

J.L. McAnally, Department Manager

Environmental Restoration and

Waste Management Department 
Management Summary DQE Performance Indicators - EG\&G Idaho. Inc. 1st Quarter CY93 


\section{OVERVIEW BY PERFORMANCE INDICATOR}

The following charts provide a summary of the performance indicator data from the first quarter of calendar year 1991 through the first quarter of 1993 from EG\&G Idaho, Inc. More detailed data on the performance indicators for each facility is provided in the Appendices to this report.

This section presents the data reported by EG\&G and the four facilities participating in the PI Program for the 26 performance indicators identified in DOE-STD-1048-92 as of the first quarter of CY 1993. As prescribed by the PI Program, two types of charts are used to present the contractor facility data. These include control and root cause charts.

The first type of chart for each PI is a control chart showing the sum of the reported values for that PI from either the EG\&G contractor total or the total of the four EG\&G facilities. This chart contains the data from the current reporting period as well as previous reporting periods and, when sufficient data exist, will be used for irend analysis. Starting with the 1st quarter of CY 1993 report, control lines were added to all PI control chiarts as directed by DOE-STD-1048-92. When making interpretations from these charts, additional care should be taken; control lines for these charts have been calculated using only nine data points. As such, a data value outside the control lines does not necessarily indicate a significant problem with the PI.

Central lines $\bar{x}$, (i.e., average (mean) of all data) and upper and lower control limits (UCL and $L C L$, respectively) are calculated for the control charts for those indicators as directed by DOE-STD-1048-92. For those indicators whose LCL is less than zero, the limit is not shown on the chant.

Root cause charts only apply to the five PIs related to DOE occurrence reporting requirements defined in DOE Order 5000.3A. These charts provide a comparison of root causes for the respective PI events and are based on cumulative data in the DOE Occurrence Reporting and Processing System from the current quarter and the preceding five quarters. Therefore, data included in the root cause charts will not necessarily correspond to the data shown on the respective PI control charts. The five PIs for which root cause data are reported and charted are as follows:

$\begin{array}{lll}\square & \text { PI 1.2 } & \text { Skin/Clothing Contaminations } \\ \square & \text { PI } 2.1 & \text { Unplanned Salety Function Actuations } \\ \square & \text { PI } 2.2 & \text { Violations of Operating Procedures } \\ \square & \text { PI } 2.3 & \text { Unplanned Shutdowns } \\ \square & \text { PI } 3.3 & \text { Environmental Incidents }\end{array}$

"It is important to recognize the diverse nature of the types, missions, and staffing levels of the facilities participating in the DOE Performance Indicator Program. Because of these differences, direct comparison of the facilities and their PI values is not appropriate and may lead to erroneous or suspect judgments regarding performance." (DOE Peformance Indicators Guidance Document, DOE-STD-1048-92, December, 1992, page 1) 


\subsection{OVERVIEW BY PERFORMANCE INDICATOR}

\subsection{PERSONNEL SAFETY}

\subsection{Collective Radiation Dose}

Definltion: The total external whole-body dose received by all facility personnel (including subcontractors and visitors) as measured by the primary dosimeter, i.e., thermoluninescent dosimeter (TLD), or film badge. Exposure measured by direct reading dosimeters should be included only for those periods or situations when more accurate data are not available. Radiation dose is reported in units of person-rem and is presented separately by deep and shallow dose. (Facility Total)

\subsubsection{Shallow Dose}

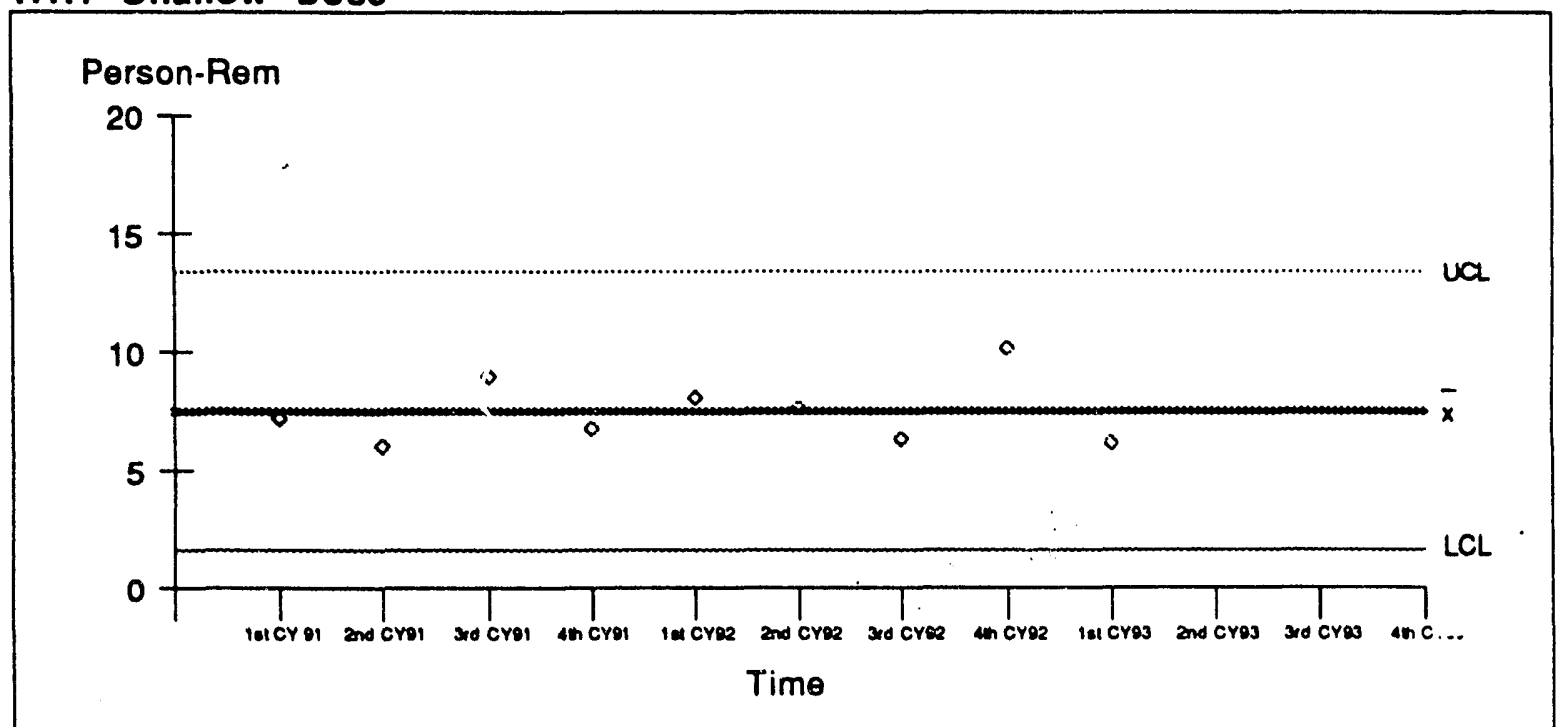

The decrease in shallow dose radiation exposures reflects the types and quantity of outage work at the ATR during the first quarter of 1993. The radiation exposures remain at levels below the ALARA goals for the year.

\subsubsection{Deep Dose}

Person-Rem

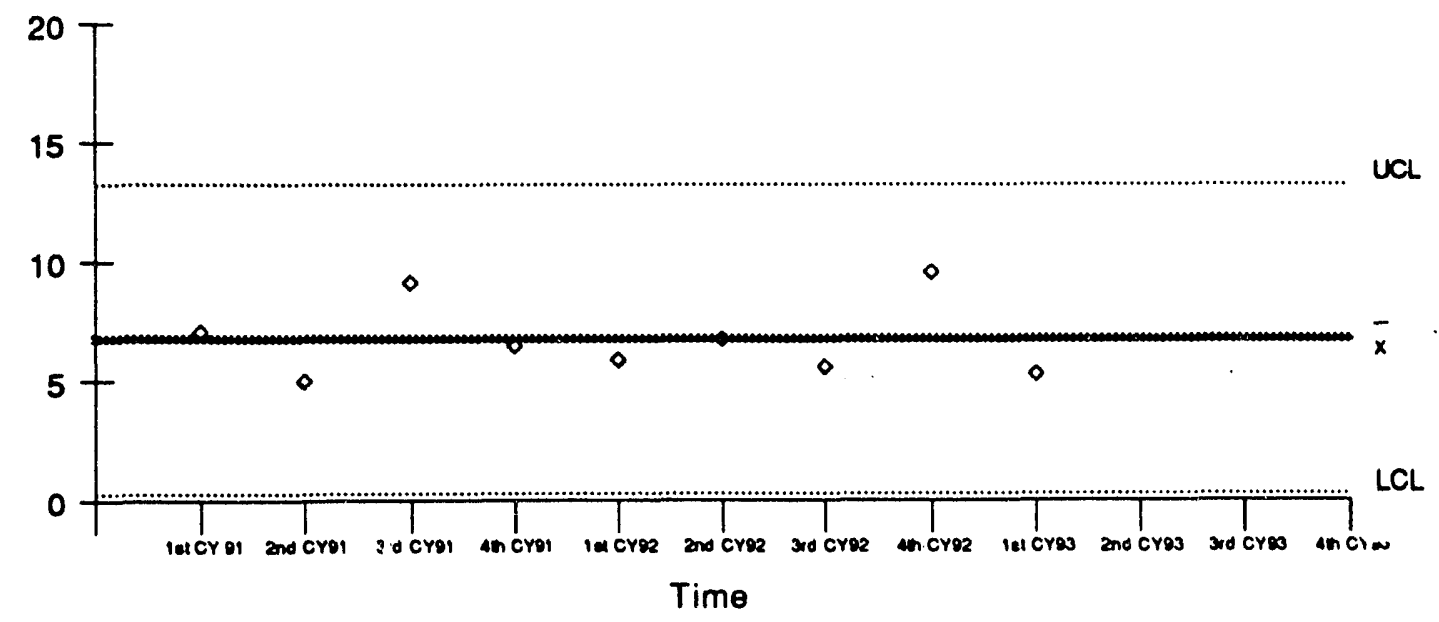

The decrease in deep dose radiation exposures reflects the types and quantity of outage work at the ATR during the first quarter of 1993. The radiation exposures remain at levels below the ALARA goals for the year. 


\section{$1.2 \mathrm{Sk} / \mathrm{n} / \mathrm{Clothing}$ Contaminations}

Definltlen: The total number of confirmed skin and personal clothing contaminations for all facility personnel, including subcontractors and visitors. Skin or clothing contaminations due to radioactive noble gases or naturally occurring radon gas are not included. (Facility Total)

Number of Events

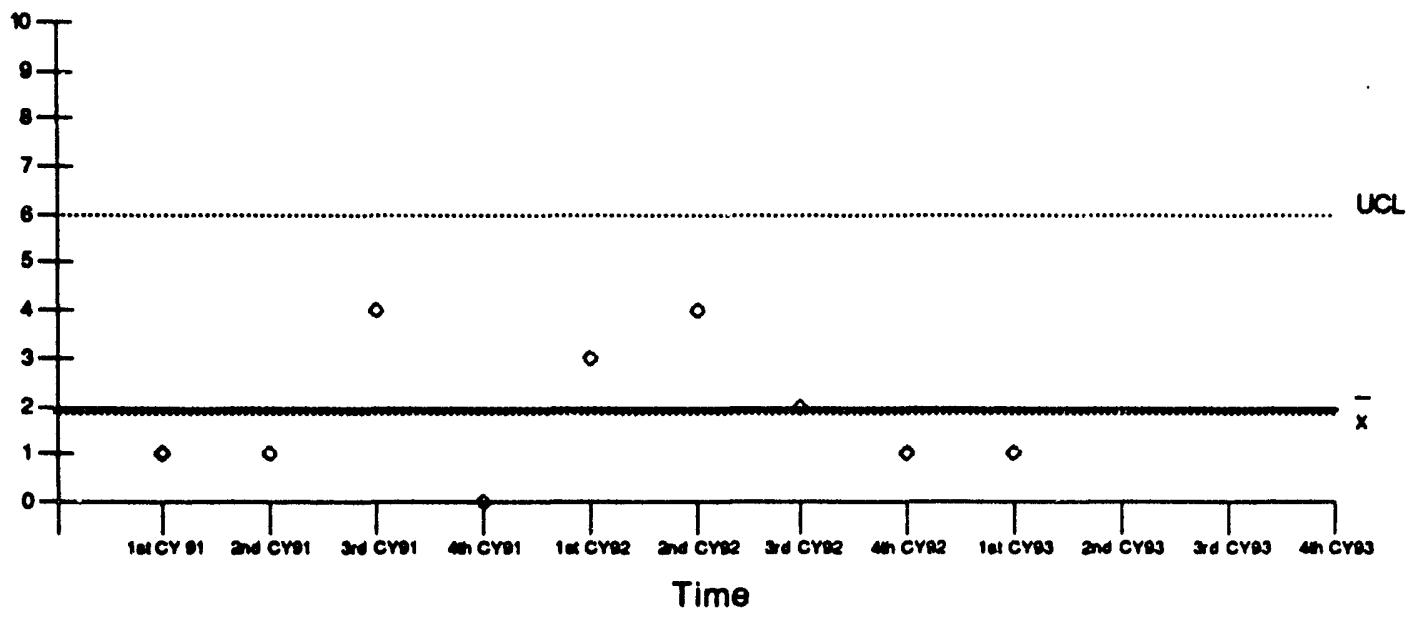

Only a single skin/clothing contamination event occurred during the first quarter of 1993 at the EG\&G facilities. The event occurred at the TRA Hot Cells and was attributable to inadequate procedures resulting in several particles being picked up on a worker's company furnished clothes during the discharge of a sample from the Hot Cells (ID--EGG-TRAHC-1993-0002). The relatively low number of skin contamination events is reflective of the increased EG\&G radiological control activities.

\subsection{Internal Contaminations}

Definition: The total number of confirmed intakes of radioactive material for all facility personnel, including subcontractors and visitors, occurring during the reporting period. (Facility Total)

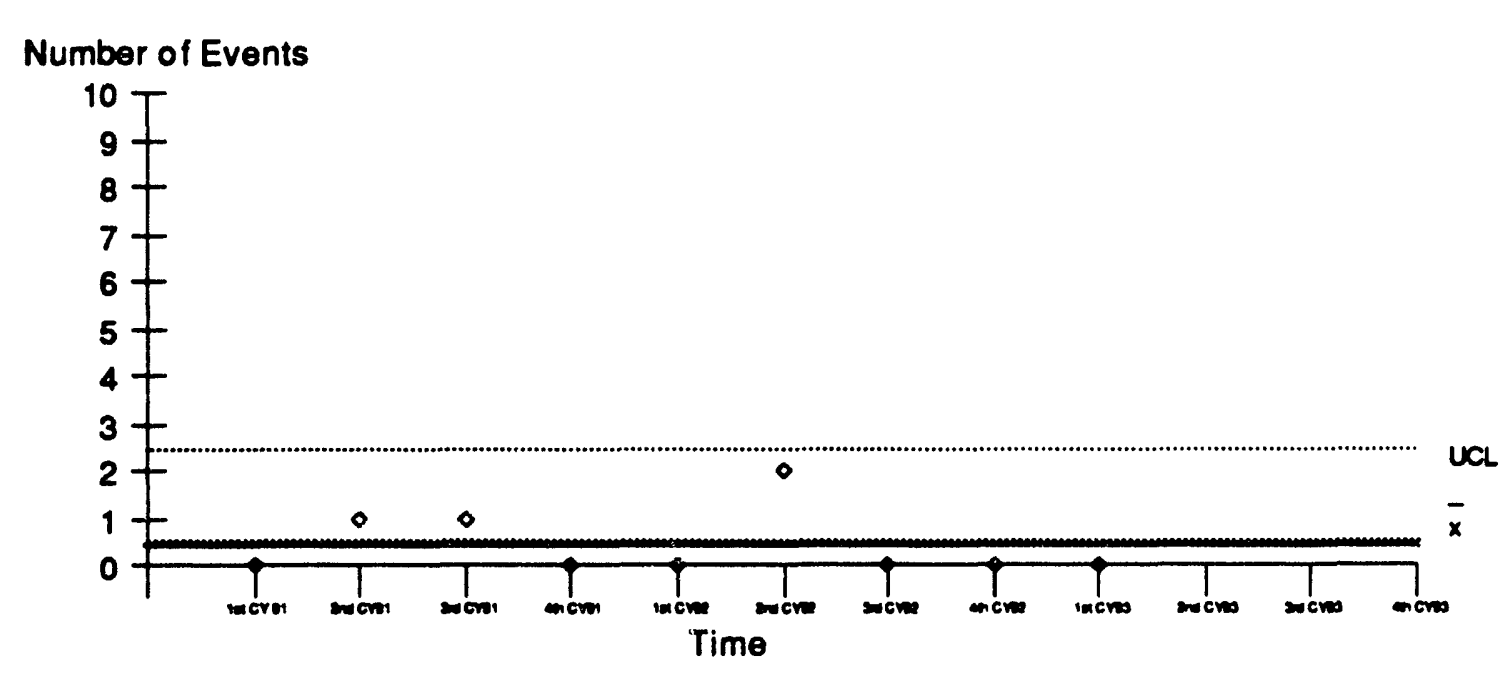

No internal contamination events occurred at any of the EG\&G facilities during the first quarter of 1993. 


\subsection{Radloactive/Hazardous Materlal Overexposures}

Definition: The number of reportable occurrences resulting from a personnel exposure (for all facility personnel, including subcontractors and visitors) to radioactive or hazardous materials in excess of limits established in DCE Orders. (Facility Total)

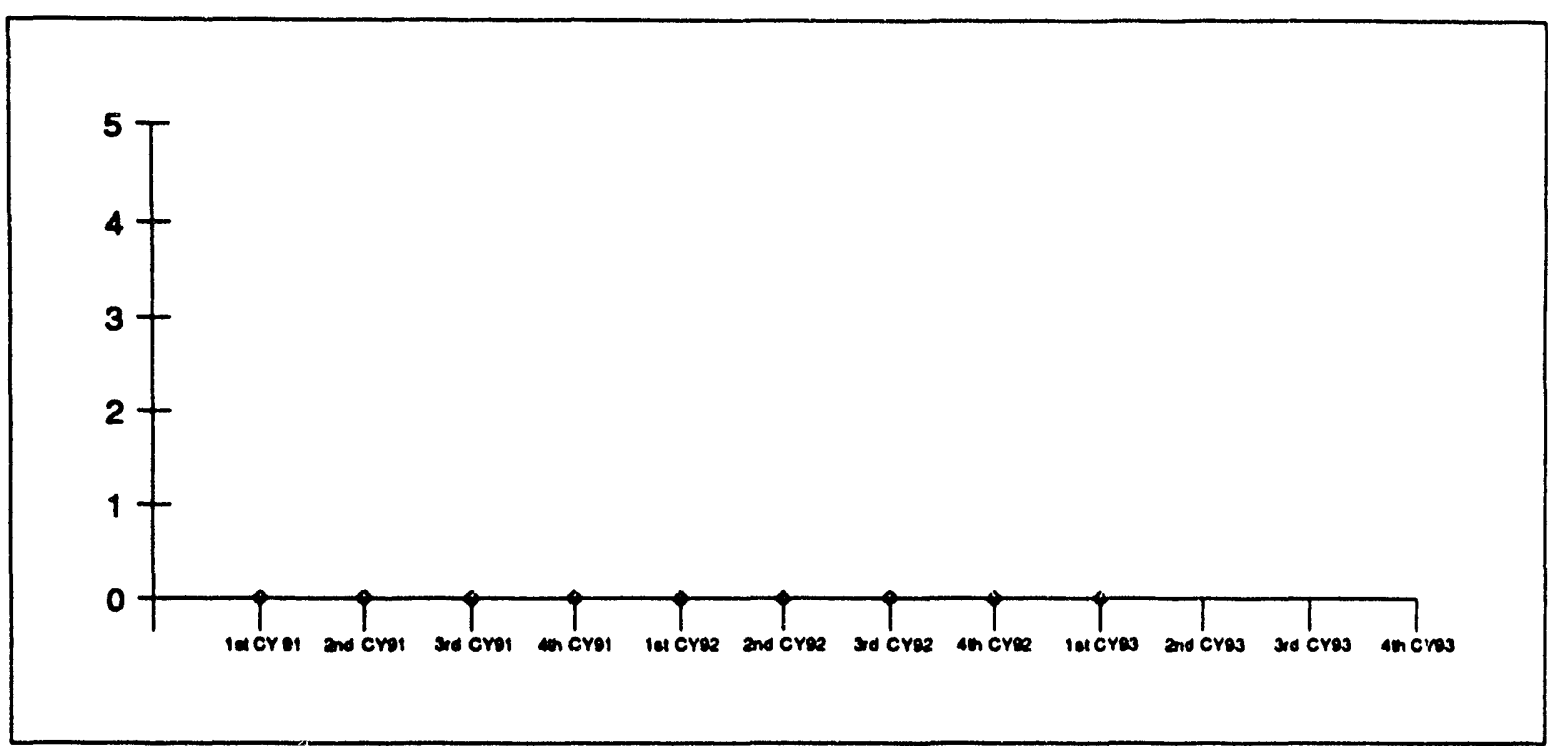

- No radioactive or hazardous material overexposures occurred at any of the EG\&G facilities during the firs quarter of 1993.

\subsection{Lost Work Day Case Rate}

Definltion: Number of incidents for all facility personnel involving days away from work per 200,000 person hours worked (100person/years). (Contractor Total)

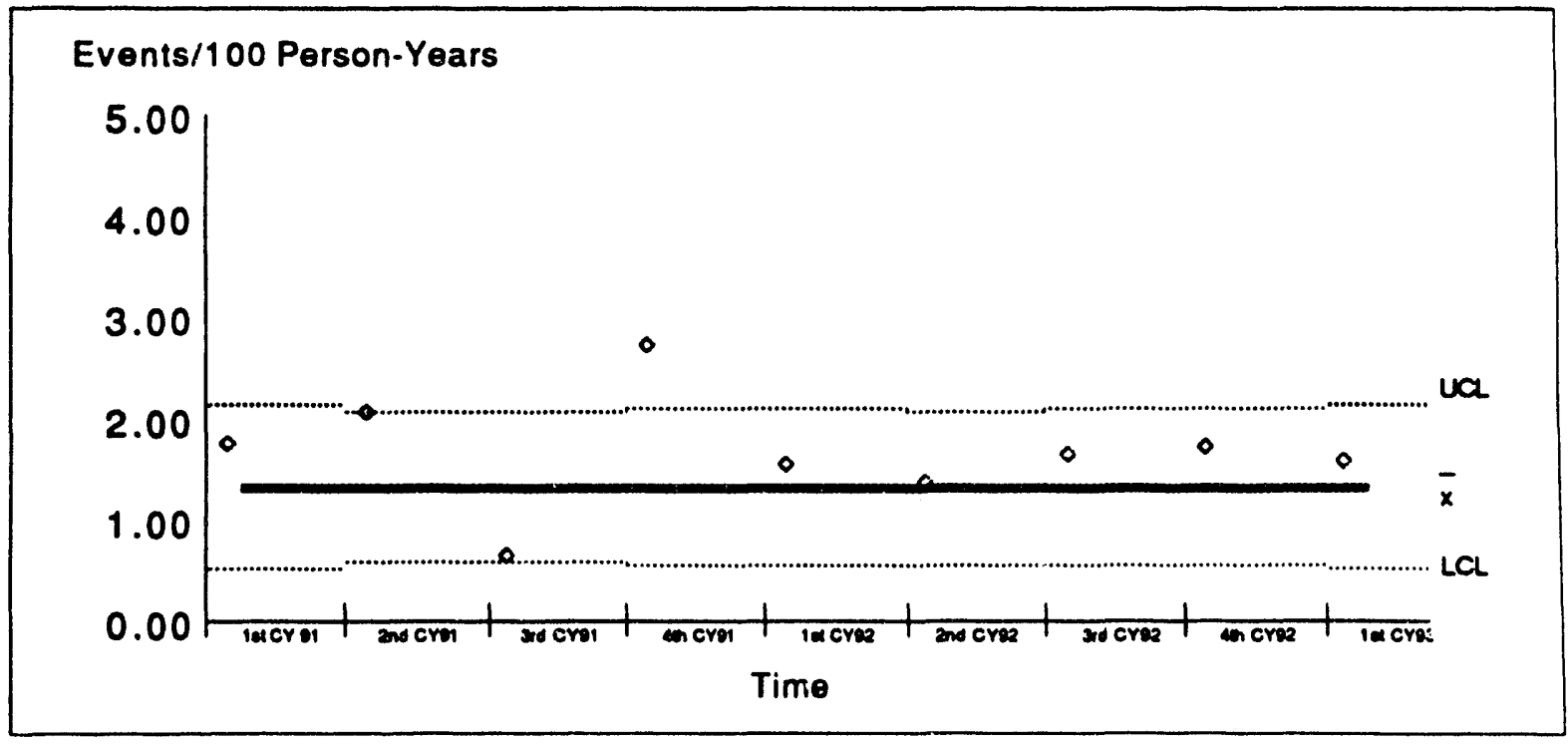

Atthough eighteen lost work day events occurred at EG\&G facilities during the first quarter of 1993, the lost work day case rate dropped from 1.72 events/100 person years in the fourth quarter of 1992 to 1.58 events/100 person years in the first quarter of 1993. This compares to an average lost time accident rate (including lost and restricted work days) of 1.7 for the DOE system, and 4.1 for U.S. industry regulated by OSHA. The majority of these events are strains (65\%) and cumulative trauma disorders (12\%). The EG\&G goal for the lost work day case rate for FY-93 is 1.29 events/100 person years. 


\subsection{Recordable Injury / IIIness Rate}

Definition: Total number of injuries or illness instances resulting from on-the-job activities that are recordable in accordance with OSHA standards, per 200,000 person-hours worked. (Contractor Total)

\section{Events/100 Person-Years}

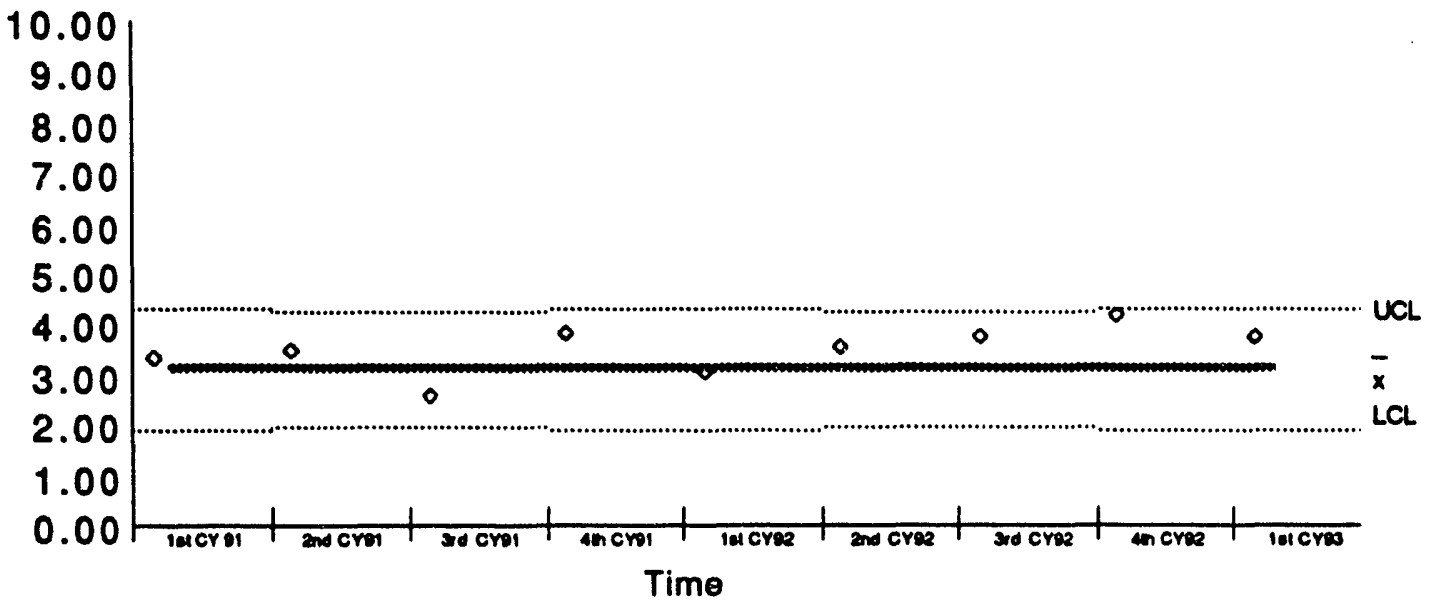

Although 43 injuryfillness cases occurred at EG\&G facilities during the first quarter of 1993, the injury/illness rate dropped from 4.16 events/100 person years in the fourth quarter of 1992 to 3.77 cases $/ 100$ person years in the first quarter of 1993. This compares to an average injury/illness rate of 3.7 for the DOE system ${ }^{a}$, and $\mathbf{8 . 8}$ for U.S. industry regulated by OSHA ${ }^{b}$. The majority of these cases are strains $(36 \%)$ and cumulative trauma disorders $(29 \%)$. The EG\&G goal for the recordable injuryfillness rate is 3.18 events/100 person years. 


\subsection{OPERATIONAL INCIDENTS}

\subsection{Unplanned Safety Function Actuations}

Definltion: The number of unplanned actuations of any safety function or facility safety systems that occur when an actuation setpoint for a safety function is reached or when a spurious or inadvertent signal is generated, and major equipment is actuated or demanded. Unplanned means that the actuation was not part of a planned test or evaluation. (Facility Total)

Number of Events

10
$9 t$
$8 t$
$7 t$
$6 t$
$5 t$
$4 t$
$3 t$
$2 t$
$1 \pm$
$0+$

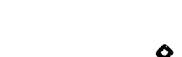

$\bullet$

No unplanned safety function actuations occurred at any of the EG\&G facilities during the first quarter of 1993.

\subsection{Violations of Operating Procedures}

Deflnltion: The number of instances where a failure of personnel to follow operating procedures resulted in a reportable occurrence. (Facility Total)

Number of Events

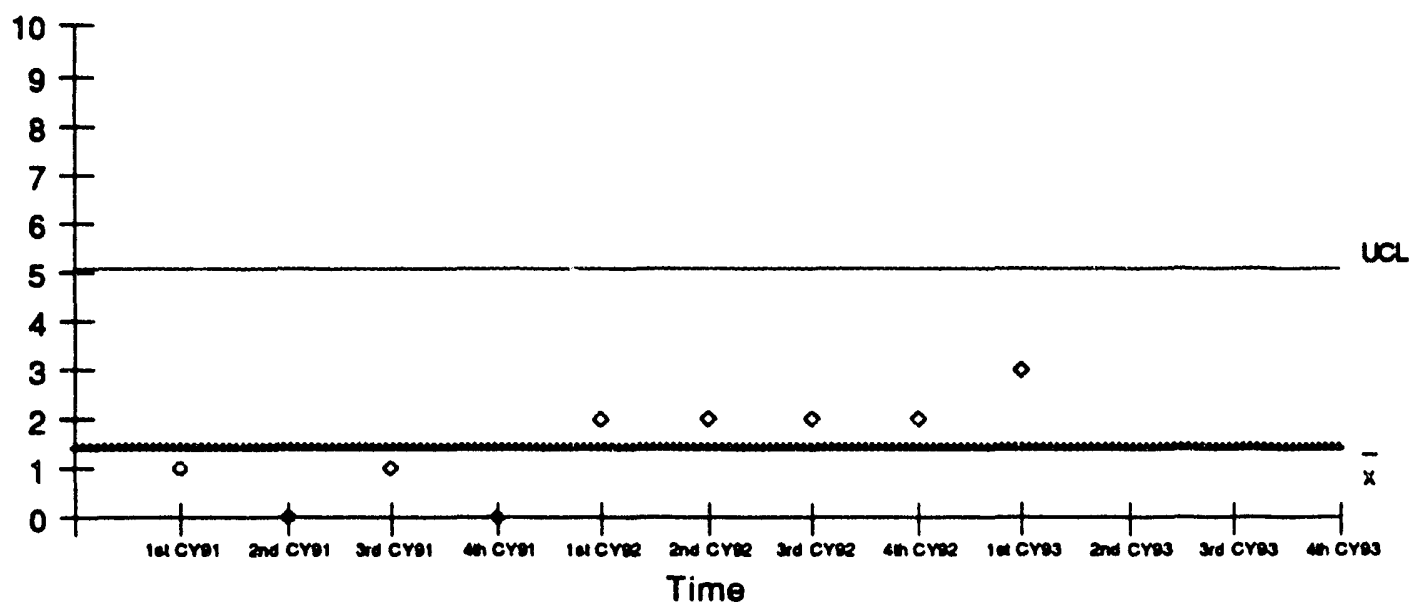

The number of violations of operating procedures increased from two events in each of the four previous quarters to three violations at the EG\&G facilities in the first quarter of 1993. All three violations occurred at the ATR and involved 1) the improper mounting of an experimental loop pump base (ID--EGG-ATR-19930004); 2) a failure to fully understand and perform a loop shutdown test (ID-.EGG-ATR-1993-0008); and 3) the inadvertent removal of a check source (ID--EGG-ATR-1993-0009). The increase from two to three violations is not signiticant and can not be attributed to any generic cause. 


\subsection{Unplanned Shutdowns}

Definition: The number of unscheduled shutdowns of a facility, process or operation. (Facility Total)

\section{Number of Events}

$$
\begin{array}{r}
20 \\
18 \\
16 \\
14 \\
12 \\
10 \\
8 \\
6 \\
4 \\
2 \\
0
\end{array}
$$

20
18
16
14
12
10
8
$6-$
$4-$
$2-$
$0 †$

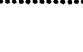

$\bullet$

$\bullet$ va

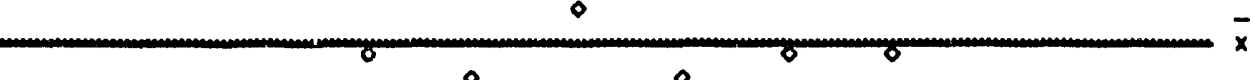

$\bar{x}$

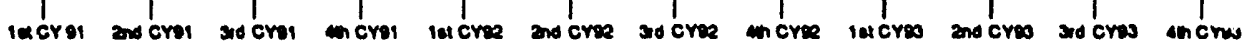

Time

The number of unplanned shutdowns at EG\&G facilities remained at three for the first quarter of 1993. All three of the first quarter unplanned shutdowns occurred at the ATR with two of the three reactor shutdowns resulting from equipment failures. One of the equipment failures was a manually initiated shutdown of the ATR when the reactor control cylinders failed to function normally (ID--EGG-ATR-1993-0006) and was also reported as an Unusual Occurrence (PI 2.4). The other equipment failure involved the failure of an experimental loop instrument (ID--EGG-ATR-1993-0005). The third ATR outage was a reactor scram initiated from an experimental loop as a result of an operator error due to a training deficiency (ID--EG\&G1993-0001).

\subsection{Emergency And Unusual Occurrences}

Definitlon: The number of Emergency and Unusual Occurrences reported in accordance with DOE Order 5000.3A, "Occurrence Reporting and Processing of Operations Information." (Facility Total)

Number of Events

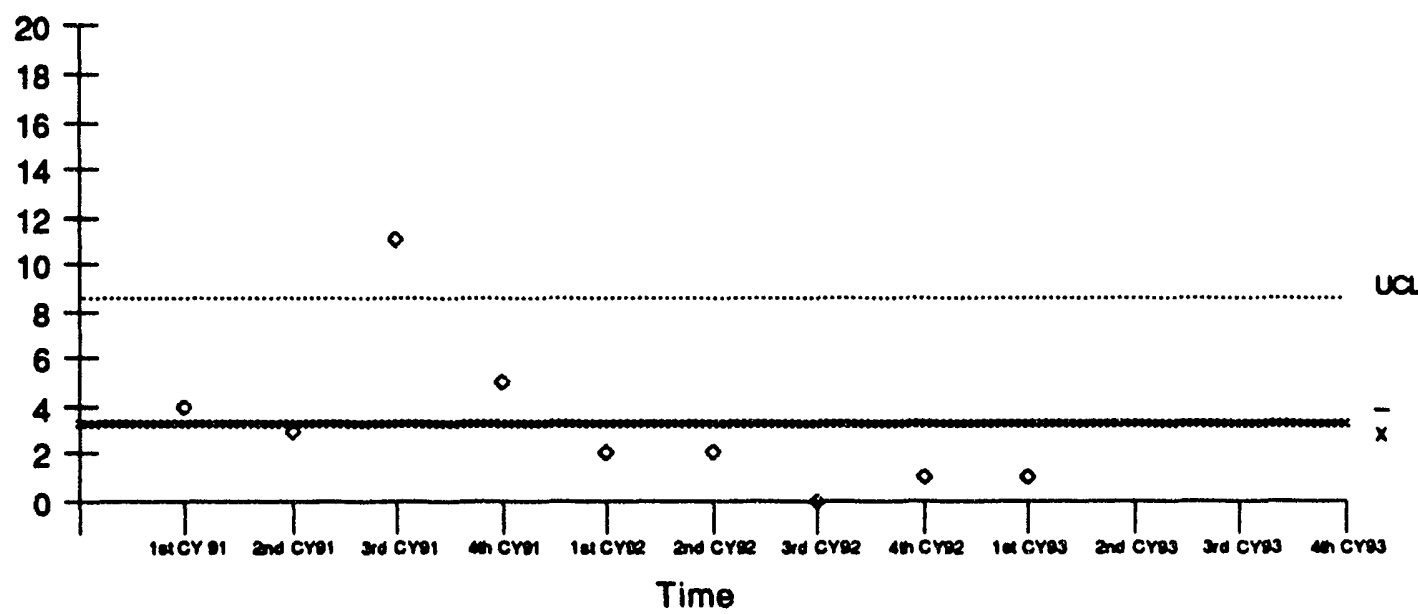

A single Unusual Occurrence Report (UOR) was issued by the EG\&G facilities during the first quarter of 1993. The single UOR was the result of an equipment failure which necessitated a manual shutdown of the ATR when the reactor control cylinders failed to function normally (ID--EGG-ATR-1993-0006). This was also reported as an unplanned shutdown (PI 2.3). 


\subsection{Substance Abuse Incldents}

Definltion: The number of reportable occurrences involving personnel use, possession or involvement of/with controlled substances, e.g., drugs, alcohol, etc. (Contractor Total)

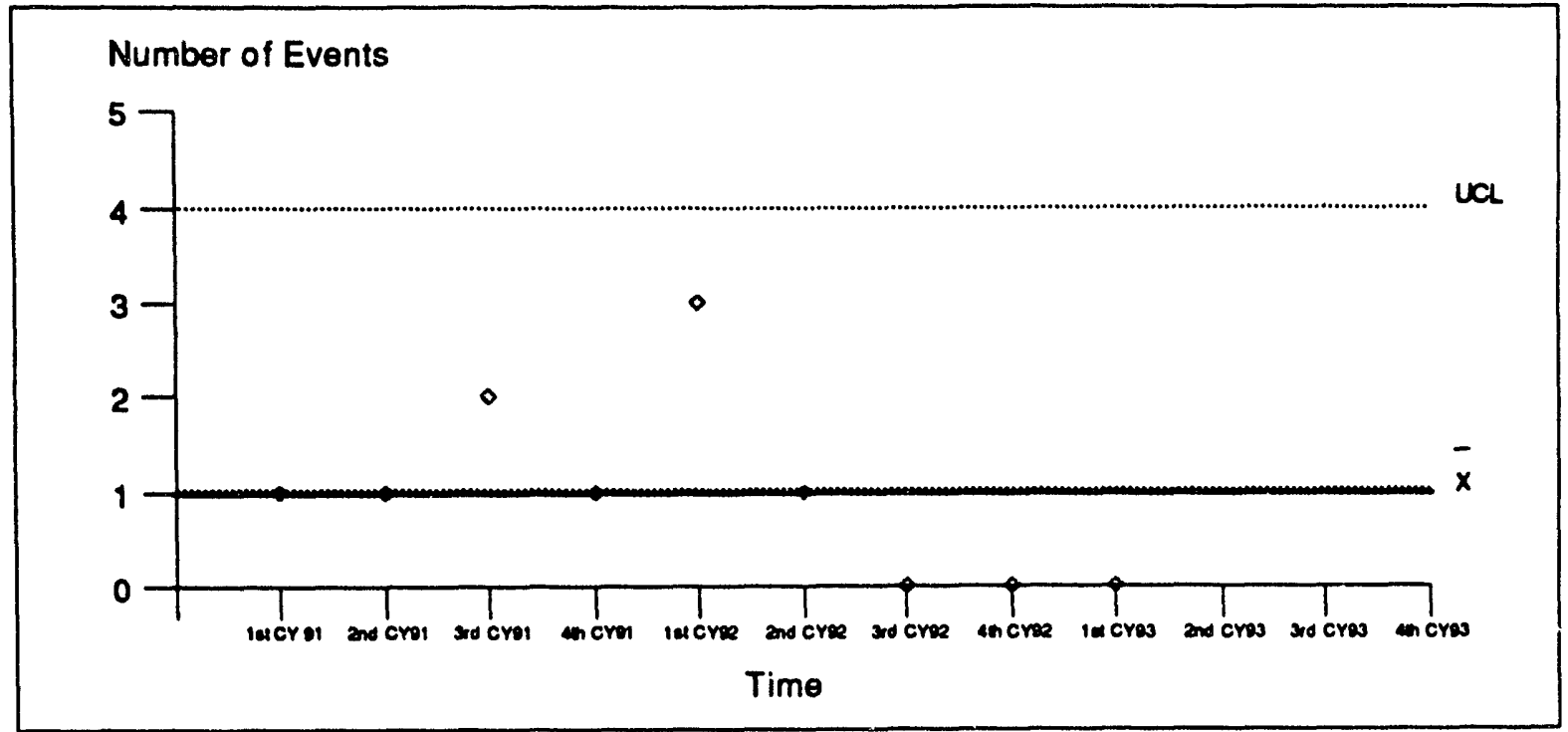

- No substance abuse incidents occurred at EG\&G during the first quarter of 1993. 
Oyenclew by $\mathrm{Pl}$ DOE Performance Indicators - EG\&G Idaho. Inc. 1st Quarter CY93 


\subsection{ENVIRONMENT}

\subsection{Radionuclide Effluent}

Definition: Separate reporting for airborne and liquid releases to the environment, as measured at the point of release, for the following radionuclides: plutonium, uranium, noble gases, particulates (including radiocesiums and radiostrontium, and activation products), radioiodine, tritium, and other actinides. (Facility Total)

\subsubsection{Alrborne}

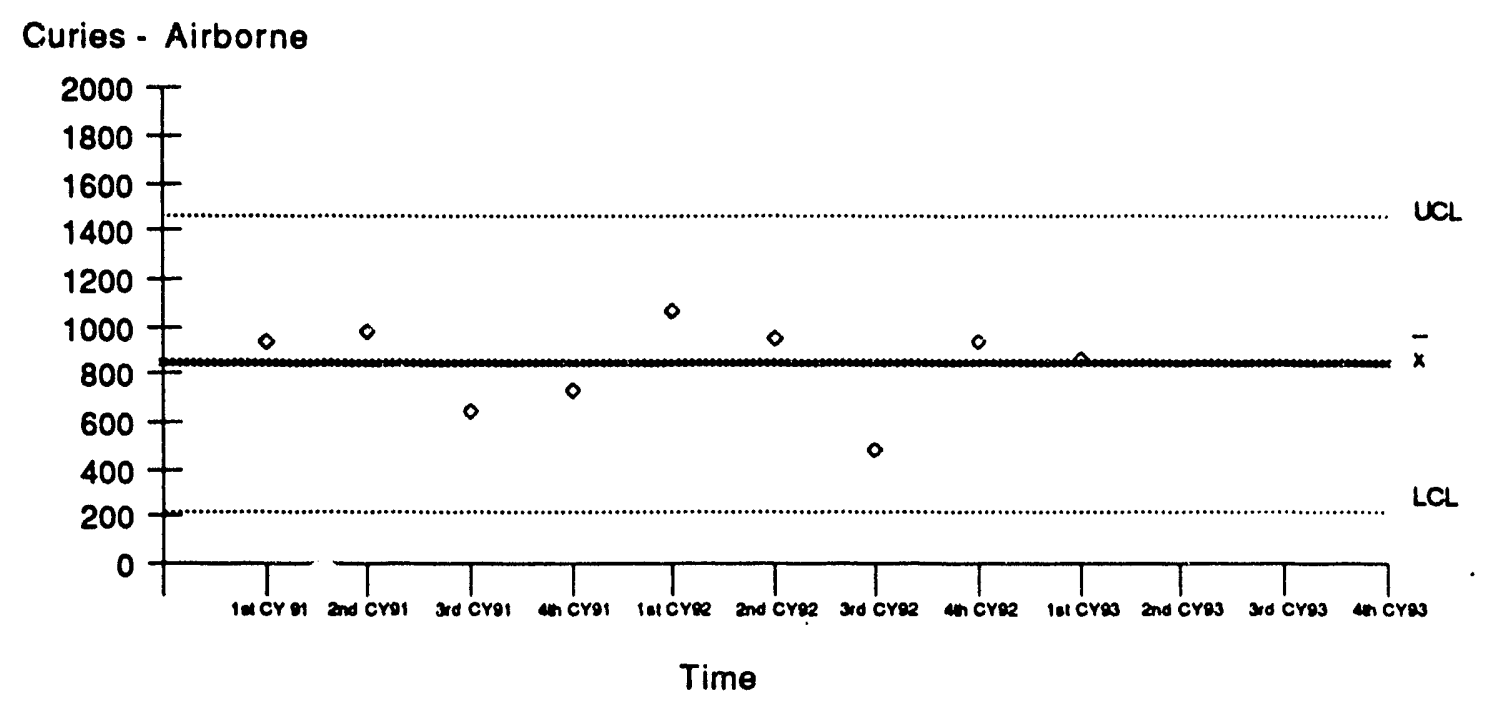

- The majority of the aiborne effluent is from the ATR nuclear fission reactor and is due to the activated argon -41 in the low pressure, low temperature primary coolant system water. The activated argon has a short half-life of 1.82 hours. An ATR design change in process will delay the release of argon allowing a substantial amount to decay before being released. Even though the ATR experienced increased megawatt-day production (power and on-stream time), the slightly lower releases during the first quarter of CY 1993 were due to the previous higher releases due to a pinhole leak in the cladding of a fuel element in Cycle 98B-1 during the fourth quarter of 1992. The TRA Hot Cells contributed $1.73 E^{-67}$ curies during the first quarter of 1993. 
1st Quarter CY93

\subsubsection{Llauld}

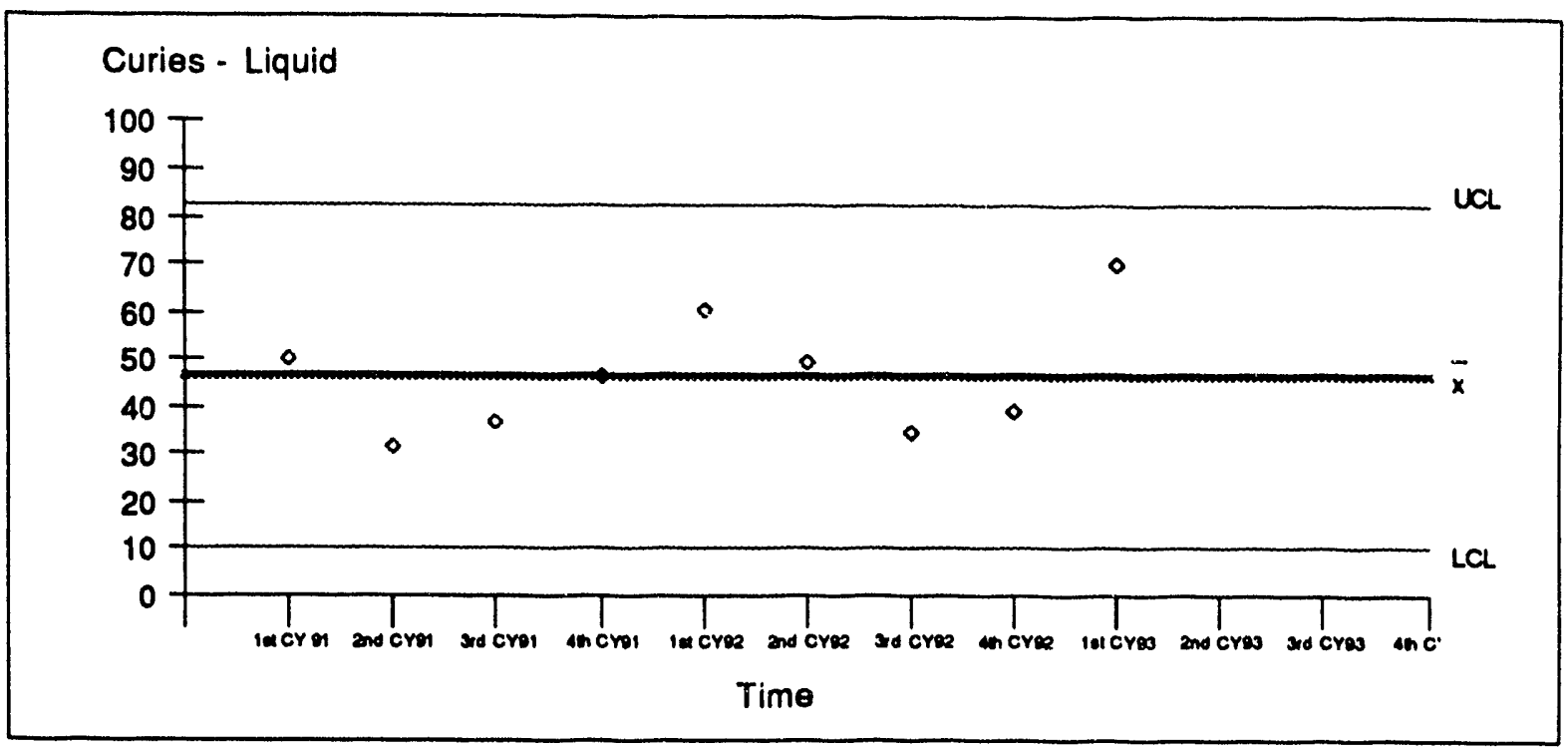

The liquid radioactive effluent release is from the ATR nuclear fission reactor and is due to the tritium (96\%) in the primary coolant system water. The tritium levels are expected to continue to increase due to the beryllium reflector continuing its predicted aging and cracking. The higher releases during the first quarter of CY 1993 were due to increased megawatt-day production (power and on-stream time). 


\subsection{Hazardous Substances/Regulated Pollutant Effluent}

Definition: Separate reporting of the amounts of "permitted" airborne and liquid nonradioactive releases. All hazardous substances and regulated pollutants that are listed in permits (e.g., Clean Air Act or NPDES permits) or otherwise reported to regulators (e.g., through SARA Title III, Section 313 reporting requirements) are included. Data shall be cumulative over is: reporting period and reported in units of pounds or gallons.(Facility Total)

\subsubsection{Alrborne}

Pounds - Airborne

10
9
8
7
6
6
5
4
$3-$
2
1
0

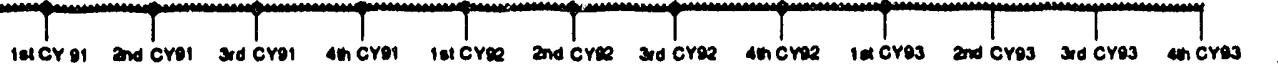

Time

No airborne hazardous substances or reguiated pollutants were released by any of the EG\&G facilities during the first quarter of 1993.

\subsubsection{Llquid}

Liquid - pounds

$$
\begin{gathered}
10 \\
9 \\
8 \\
7 \\
6 \\
5 \\
4 \\
3 \\
2 \\
1 \\
0
\end{gathered}
$$
va

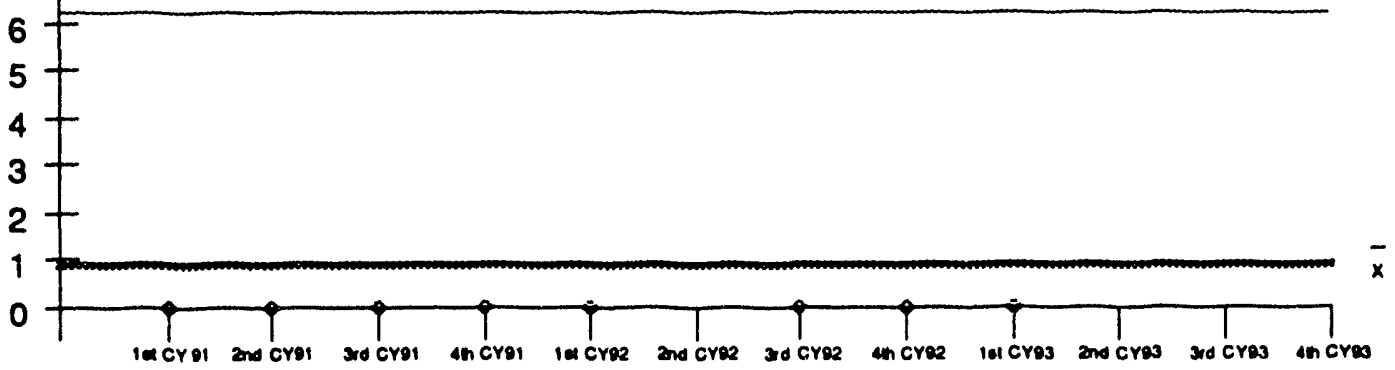

Time

No liquid hazardous substances or regulated pollutants were released by any of the EG\&G facilities during the first quarter of 1993. 


\subsection{Environmental Incidents}

Definltion: The number of reportable occurrences, both on-site and off-site, involving an inadvertent radioactive or hazardous material spill or release. (Facility Total)

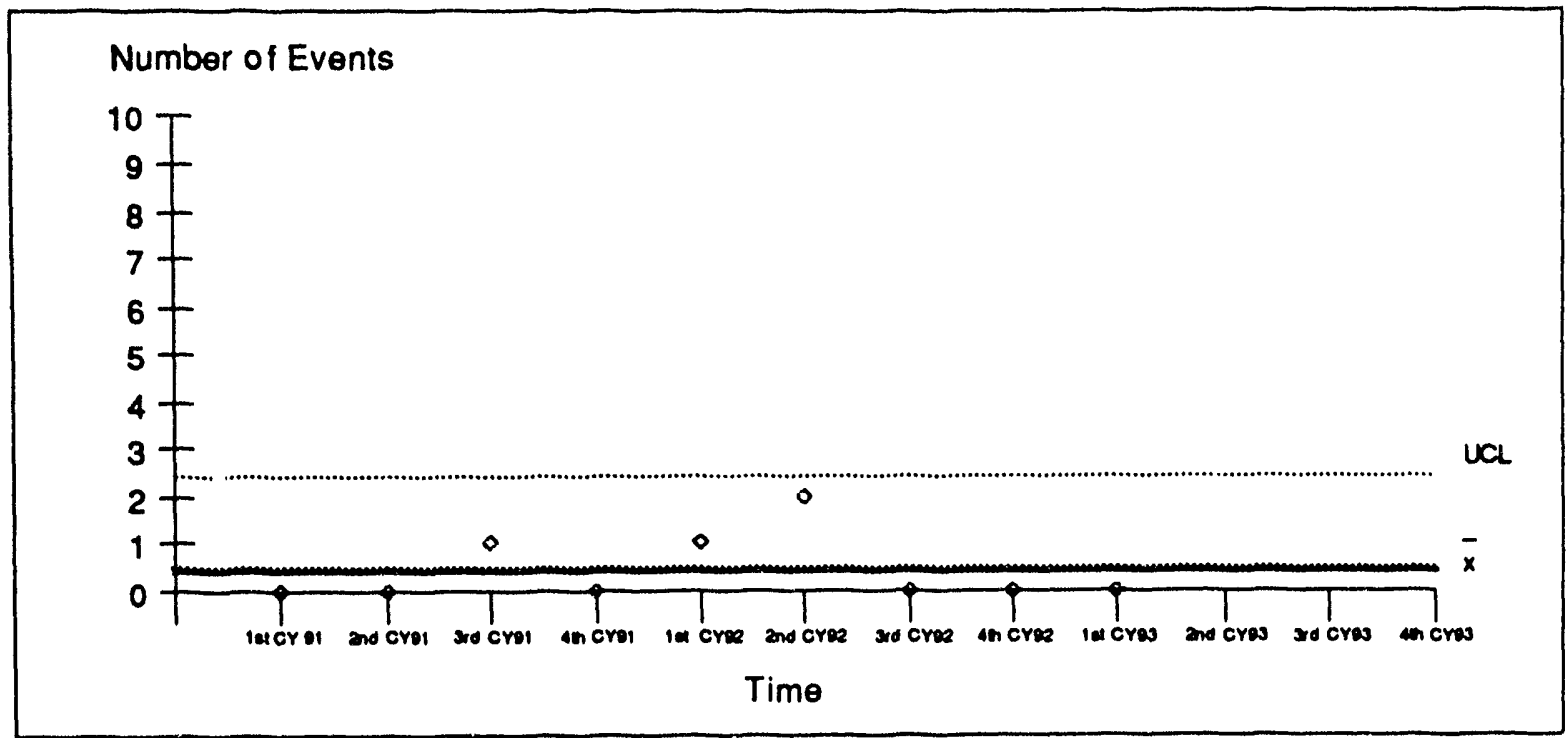

- No environmental incidents occurred at any of the EG\&G facilities during the first quarter of 1993.

\subsection{Solid Low Level Waste Generated}

Definition: The total volume, in cubic feet, of solid low level radioactive and/or hazardous and/or mixed waste generated during the reporting period. (Facility Total)

\subsubsection{Radloactlve waste}

Cubic Feet

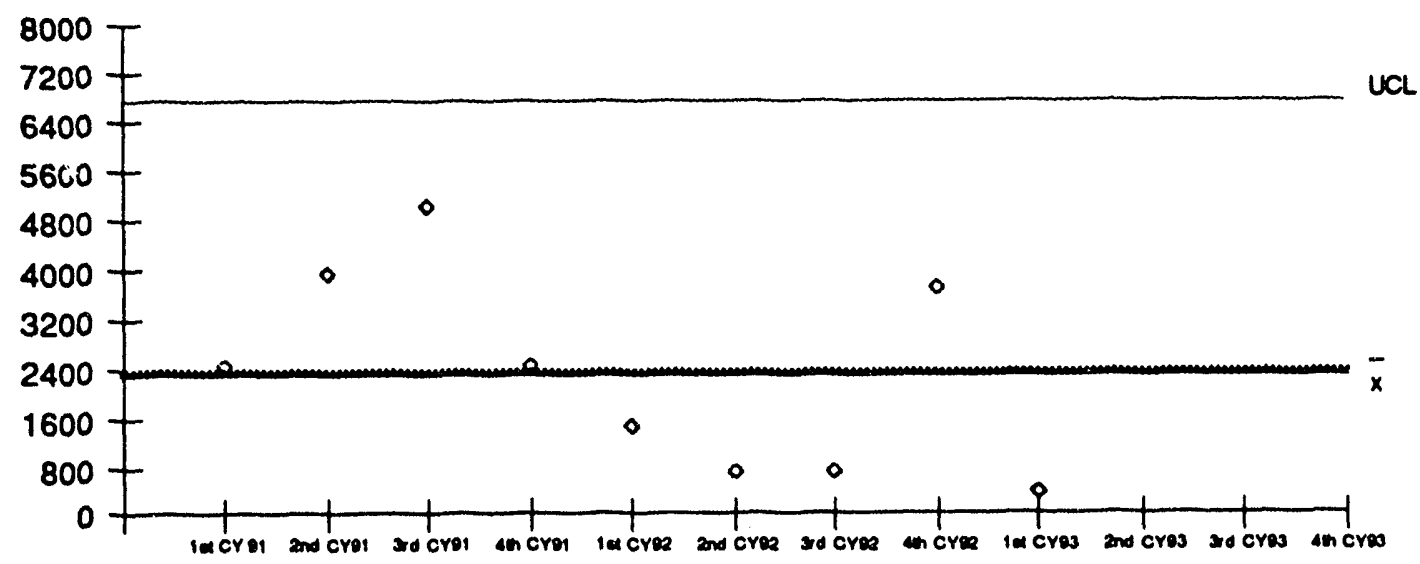

Time

- The amount of low level radioactive waste generated in this reporting period decreased primarily due to concentrated efforts during the fourth quarter of 1992 by the ATR to collect, characterize, and ship waste from various ATR accumulation areas. In addition, the fourth quarter of 1992 also contained the low level radioactive waste generated by the RWMC during decontamination activities at the Certified and Segregated Waste Storage Building. The first quarter of 1993 low level radioactive waste was generated by the WERF during incinerator refractory replacement and at the other facilikies during routine operations. 


\subsubsection{Hazardous waste}

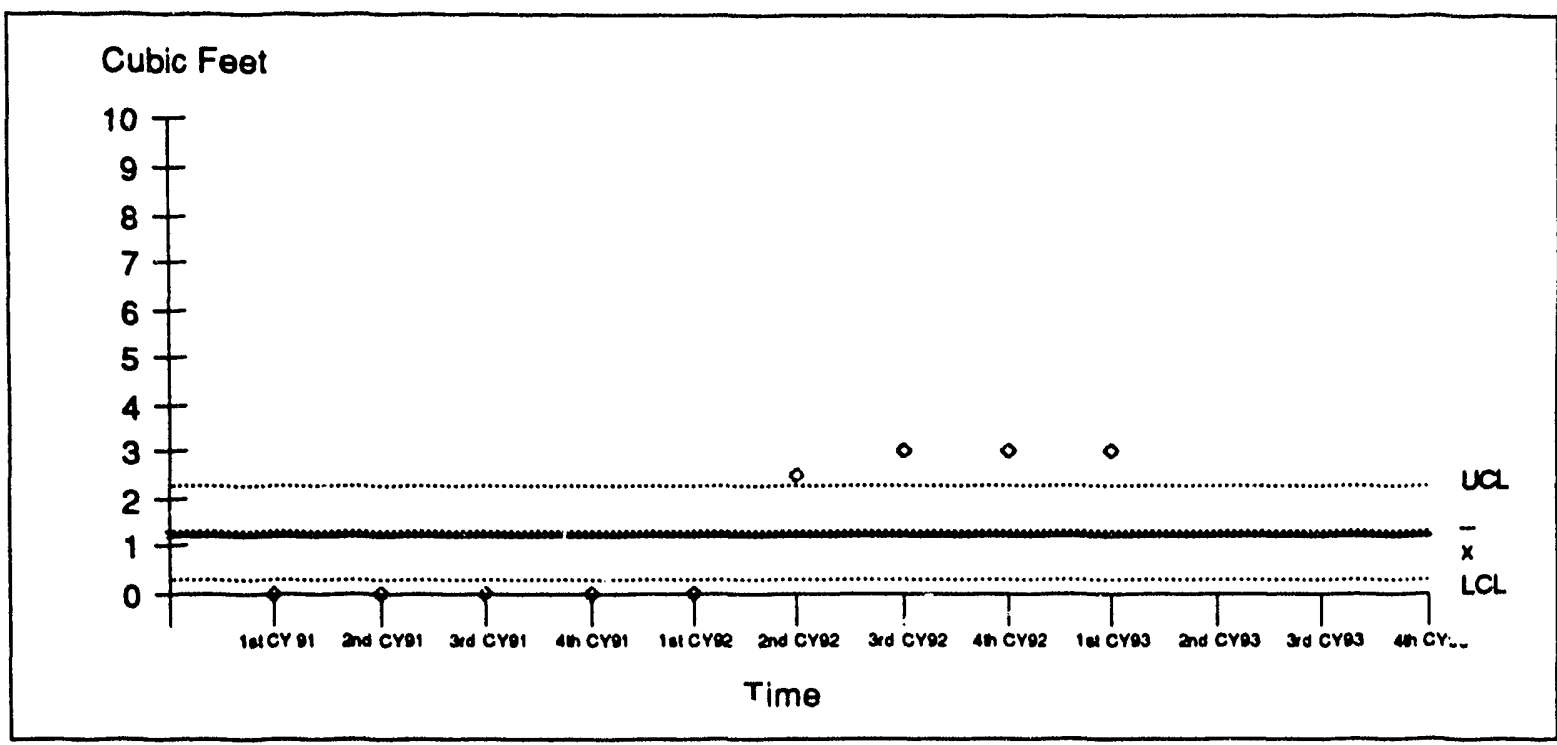

The low level hazardous waste that was generated in the first quarter of CY 1993 was three industrial lead acid batteries from the RWMC that were returned for recycling.

\subsubsection{Mixed waste}

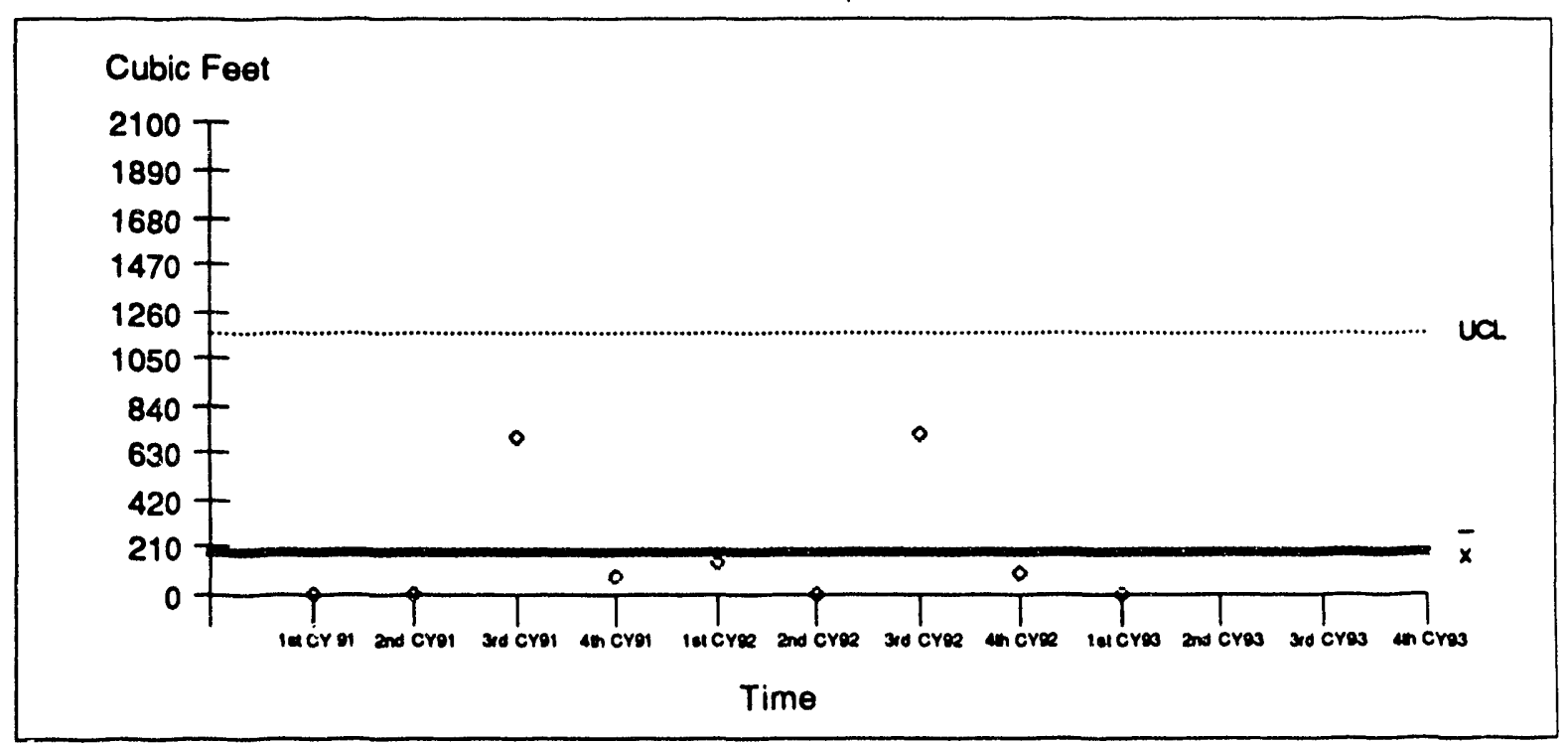

- No mixed waste was generated at any of the EG\&G facilities during the first quarter of 1993. 


\subsection{MANAGEMENT}

\subsection{DOE Audit Issues}

Definition: The total number of findings, including concerns and recommendations requiring corrective actions, by oversight assessments and line program self-assessments for which contractor corrective actions have not been completed at the time of the report. (Contractor Total)

Number of Issues

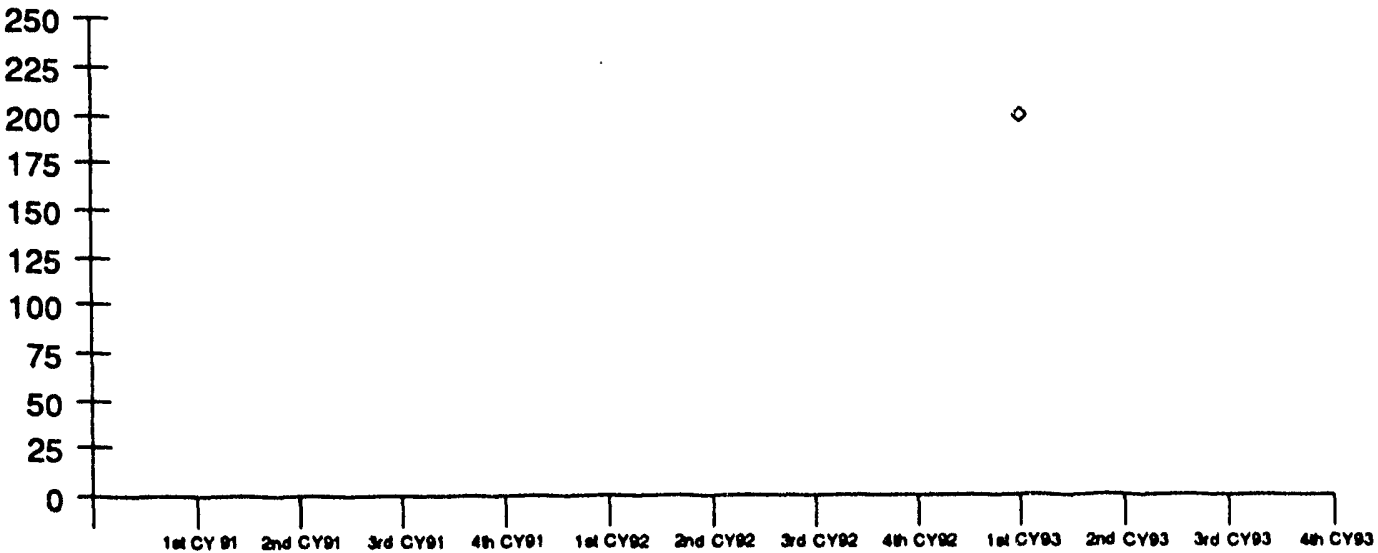

Time

This PI was previously defined as a facility total of the number of open DOE Audit Issues at the end of the quarter. It is now defined as a contractor total of the number of DOE Audit Issues that have been open greater than 90 days at the end of the quarter. It was not possible to backfit data for this indicator as the information has been kept at the facilities and only as the number of issues open rather than the number of issues open greater than 90 days. Tharefore, data for this indicator are only charted from first quarter 1993 forward and, due to the limited amount of data, no control lines are computed. Trend determinations will be made once sufficient data exist for this indicator as currently defined. 
1st Quarter CY93

\subsection{External Organization Issues}

Definition: The total number of recommendations by external organizations, such as the Advisory Committee on Nuclear Facility Safety, the Defense Nuclear Facility Safety Board, the National Academy of Sciences, etc., directed to specific contractors or their facility operations, for which contractor corrective actions have not been completed at the time of the report. (Contractor Total)

Number of Recommendations

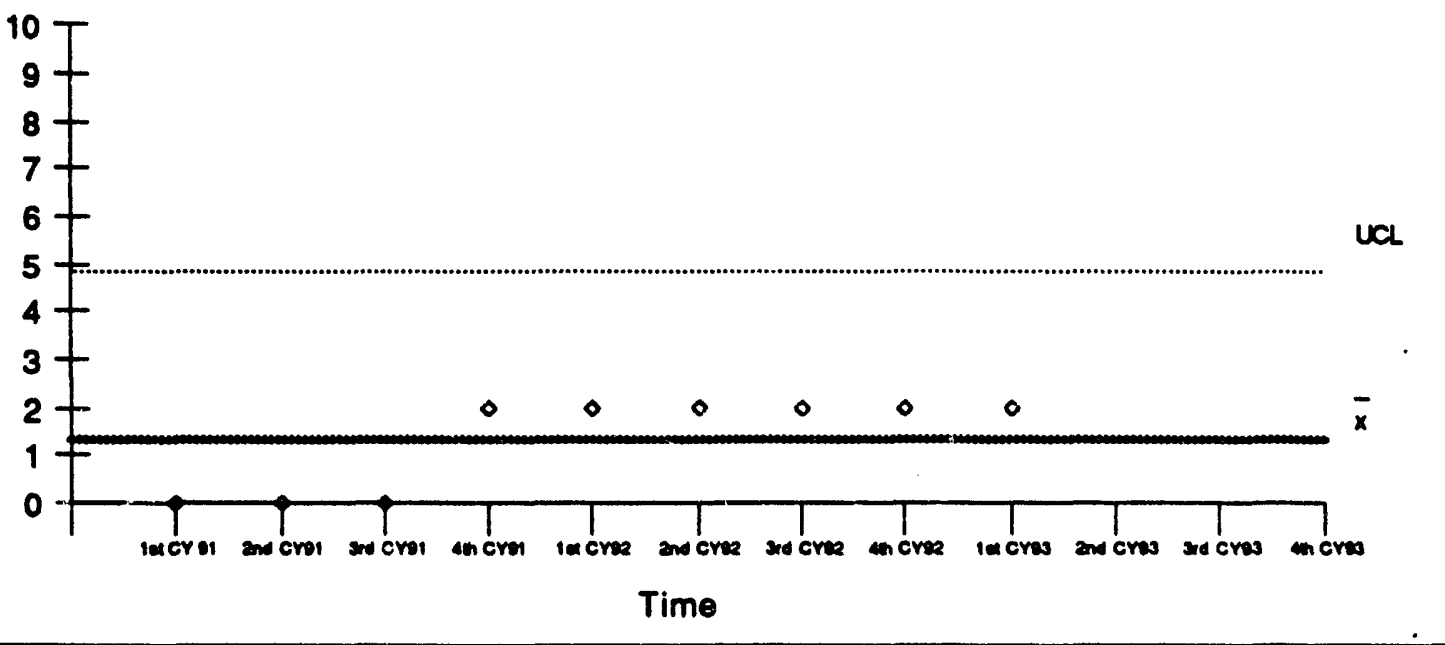

The two open external organization recommendations were identified at RWMC during the Waste Isolation Pibt Plant (WIPP) audits by the Waste Acceptance Criteria Certification Committee (WACCC) in the third quarter of 1991. This PI was previously a tacility total of the number of open External Organization Issues at the end of the quarter. It is now a contractor total of the number of External Organization Issues that heve been open greater than 90 days at the end of the quarter. No additional issues were identified when this indicator became a contractor total. However, the data for the third quarter of 1991 is now 0 instead of 2 , since these issues had not yet been open greater than 90 days. 


\subsection{OSH Noncompllance}

Definltion: The total number of items of noncompliance with OSHA standards. (Contractor Total)

Number of Events

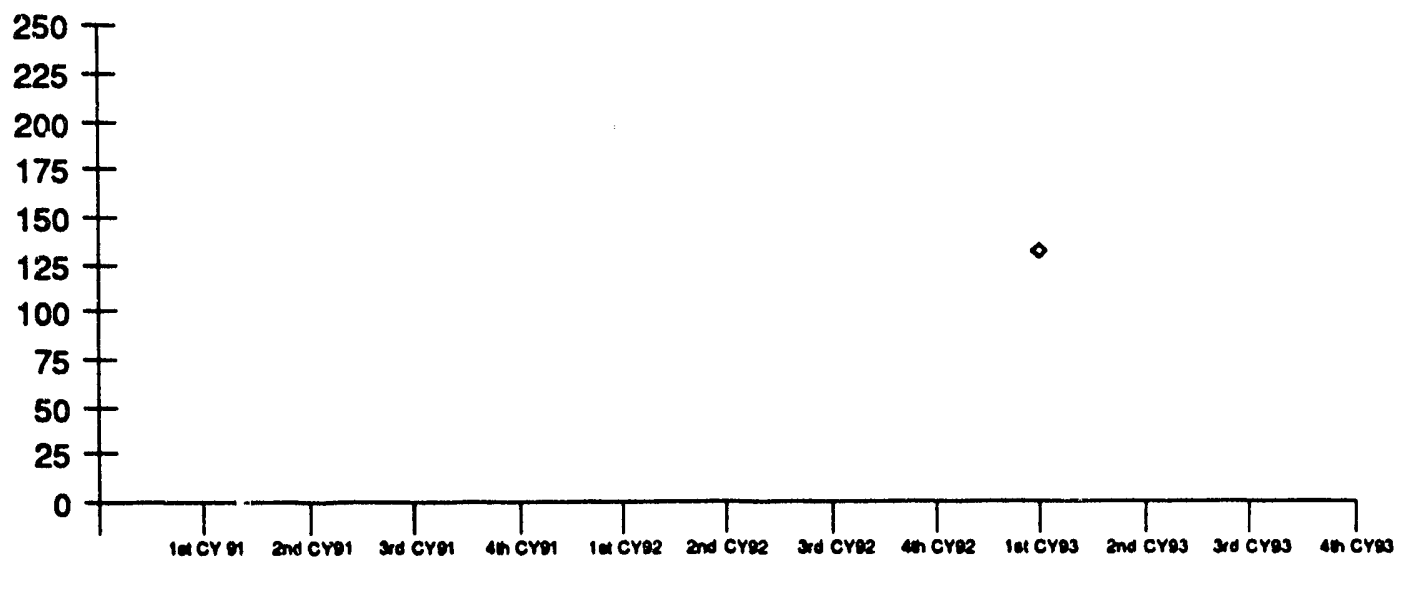

Time

The definition for this indicator was changed from the number of OSH violations identified at the facilities during the quarter to the number of OSH noncompliances open greater than 90 days for the contractor at the end of the quarter. It was not possible to backfit data for this indicator as the information has been kept at the facilities and only as the number of issues identified during the current quarter rather than the number of issues open greater than 90 days. Additionally, no company level system exists to track the information as currently required. Therefore, reporting for this indicator will continue to be a facility total until such time as a system is in place to track these issues at a company level. It is currently planned to have a tracking system in place and functional by the first quarter of 1994.

Ar shown in the chart above, data for this indicator are only charted from first quarter 1993 forward and, due to the limited data, no control lines are computed. 


\section{1 st Quarter CY93}

\subsection{Corrective Maintenance Backlog}

Definition: The percentage of open corrective maintenance work requests, including those requiring facility or process shutdown, that are greater than three months old at the end of the reporting period. Corrective maintenance may include minor modifications if performed under a corrective maintenance work request. (Facility Total)

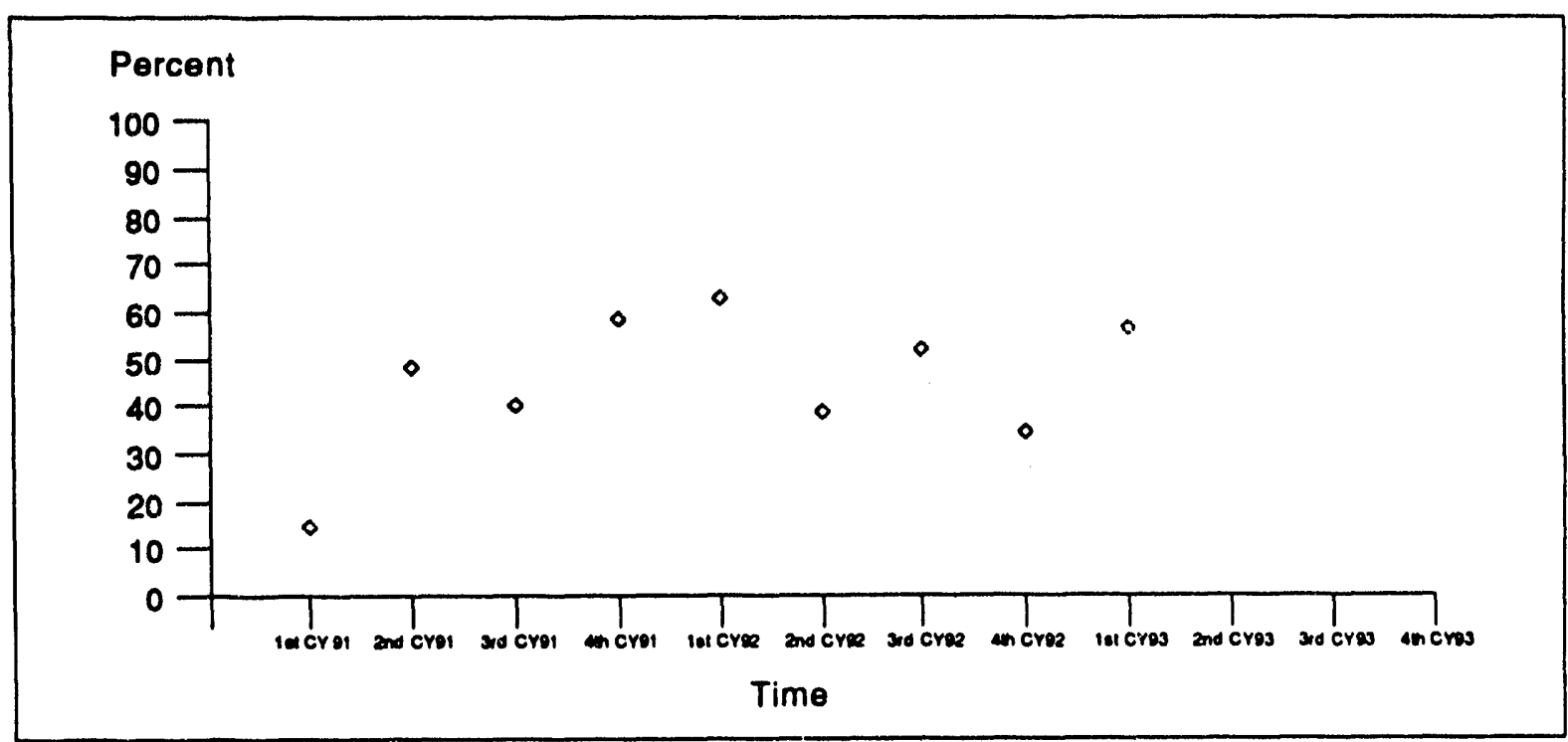

During the fourth quarter of 1992 at EG\&G facilities, there were $142 \mathrm{CM}$ items open greater than three months versus a total of 413 open $(34 \%)$. For the first quarter of 1993, the total number of open items increased to 423 , with $237 \mathrm{CM}$ items open longer than three months $(56 \%)$. The corrective maintenance backlog increased during the first quarter of 1993 because the ATR assigned priority work towards the preparation for the Process Control Upgrade outage in the second quarter of 1993.

\subsection{Preventlve MaIntenance Overdue}

Definition: The percentage of preventive maintenance items that were not completed within the original scheduled interval.(Facility Total)

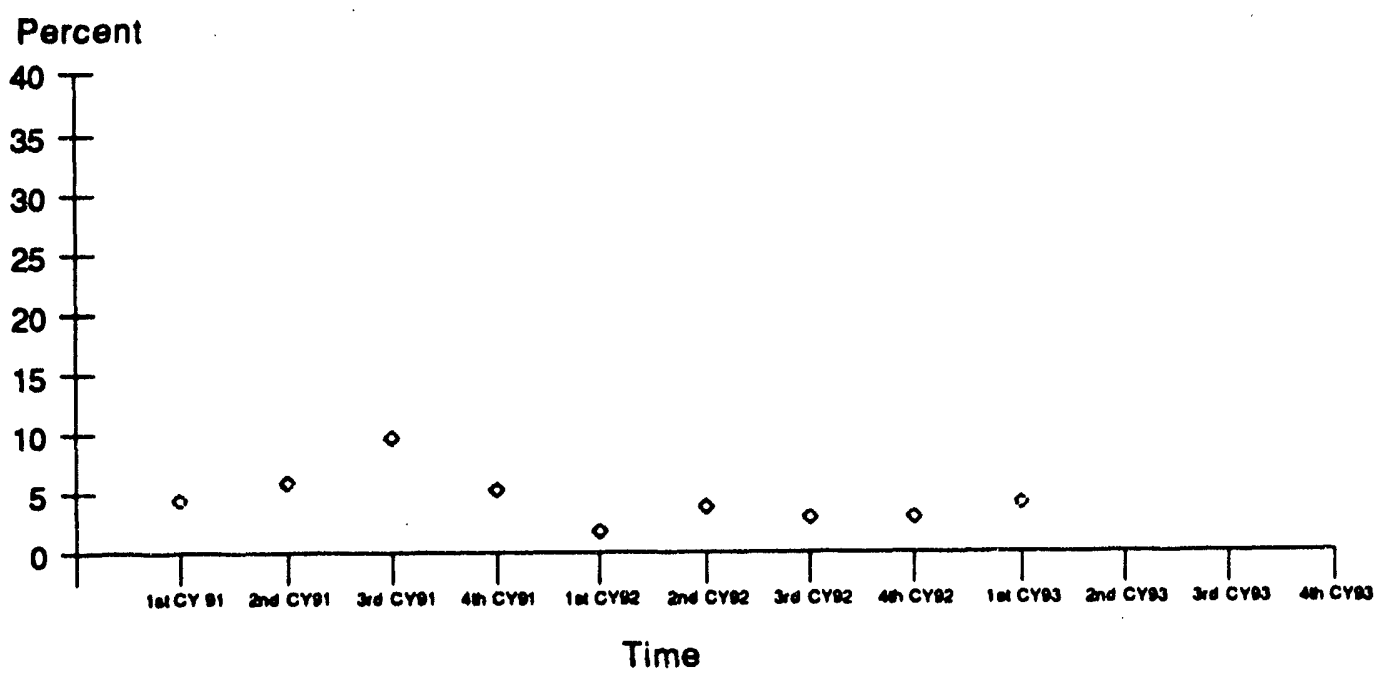

During the fourth quarter of 1992 at EG\&G facilities, 3.04\% of the scheduled PM items were not completed within the originally scheduled interval (25 of 822$)$. For the first quarter of $1993,4.05 \%$ of the scheduled PM items were not cornpleted within the originally scheduled interval (24 of 592). 


\subsection{Occurrence Reports With Open Corrective Action}

Definition: The number of Final Occurrence Reports for which all corrective actions have not been completed at the time of the report. (Facility Total)

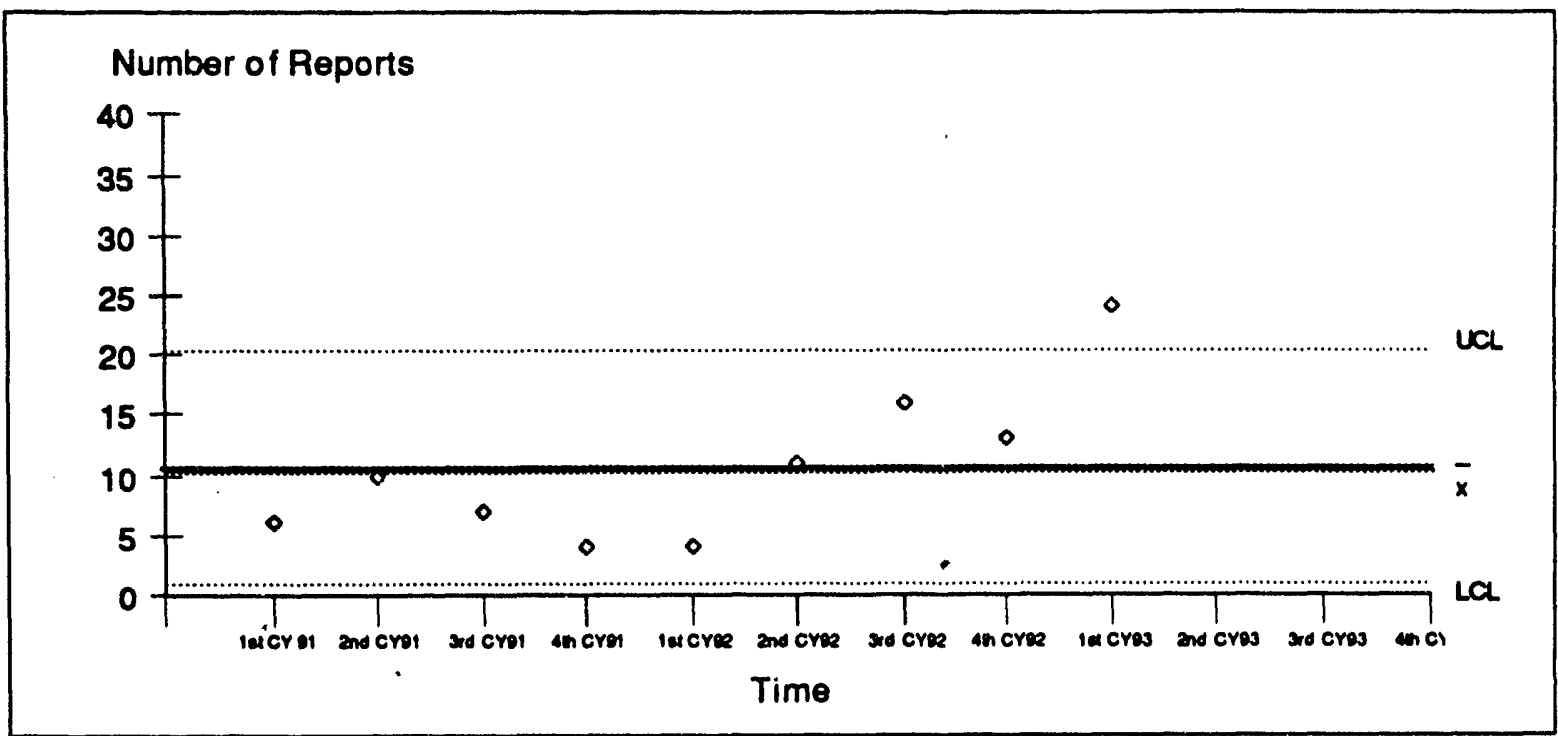

At the close of the first quarter, 24 Final Occurrence Reports (ORs) had open corrective actions at EG\&G facilities (ATR-14, RWMC-6, and WERF-4). The increased number of occurrence reports reflects the increased emphasis on finalizing ORs. 


\subsection{OVERVIEW BY ROOT CAUSE}

\section{Boot Cause Charts}

The remaining chart type, the root cause chart, only applies to the five PIs related to DOE occurrence reporting requirements defined in DOE Order 5000.3A. These charts provide a comparison of determined root causes for the respective $\mathrm{PI}$ events and are based on cumulative data in the DOE Occurrence Reporting and Processing System from the current quarter and the previous five quarters. Therefore, data included in the root cause charts will not necessarily correspond to the data shown on the respective PI control charts. The five PIs for which root cause data are reported and charted are as follows:

$\begin{array}{lll}\square & \text { PI 1.2 } & \text { Skin/Clothing Contaminations } \\ \square & \text { PI } 2.1 & \text { Unplanned Safety Function Actuations } \\ \square & \text { PI } 2.2 & \text { Violations of Operating Procedures } \\ \square & \text { PI } 2.3 & \text { Unplanned Shutdowns } \\ \square & \text { PI } 3.3 & \text { Environmental Incidents }\end{array}$

"It is important to recognize the diverse nature of the types, missions, and staffing levels of the facilities participating in the DOE Performance Indicator Program. Because of these differences, direct comparison of the facilities and their PI values is not appropriate and may lead to erroneous or suspect judgments regarding performance." (DOE Pefformance Indicators Guidance Document, DOE-STD-1048-92, December, 1992, page 1)

\subsection{PERSONNEL SAFETY}

\subsection{Skin/Clothing Contaminations}

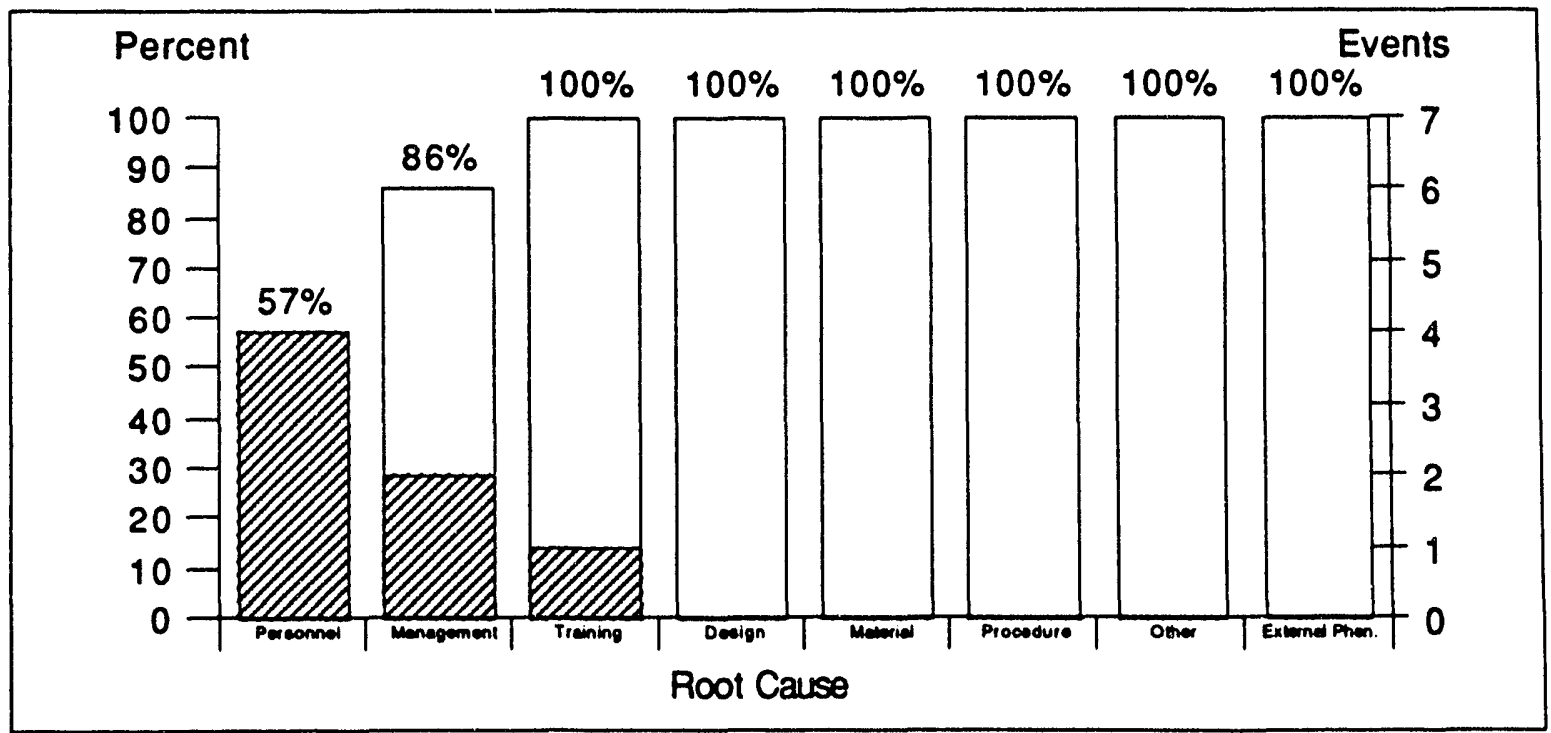


Overview by PI

1st Quarter CY93

DOE Performance Indicators - EG\&G Idaho. Inc.

2.0 OPERATIONAL INCIDENTS

\subsection{Unplanned Safety Function Actuations}

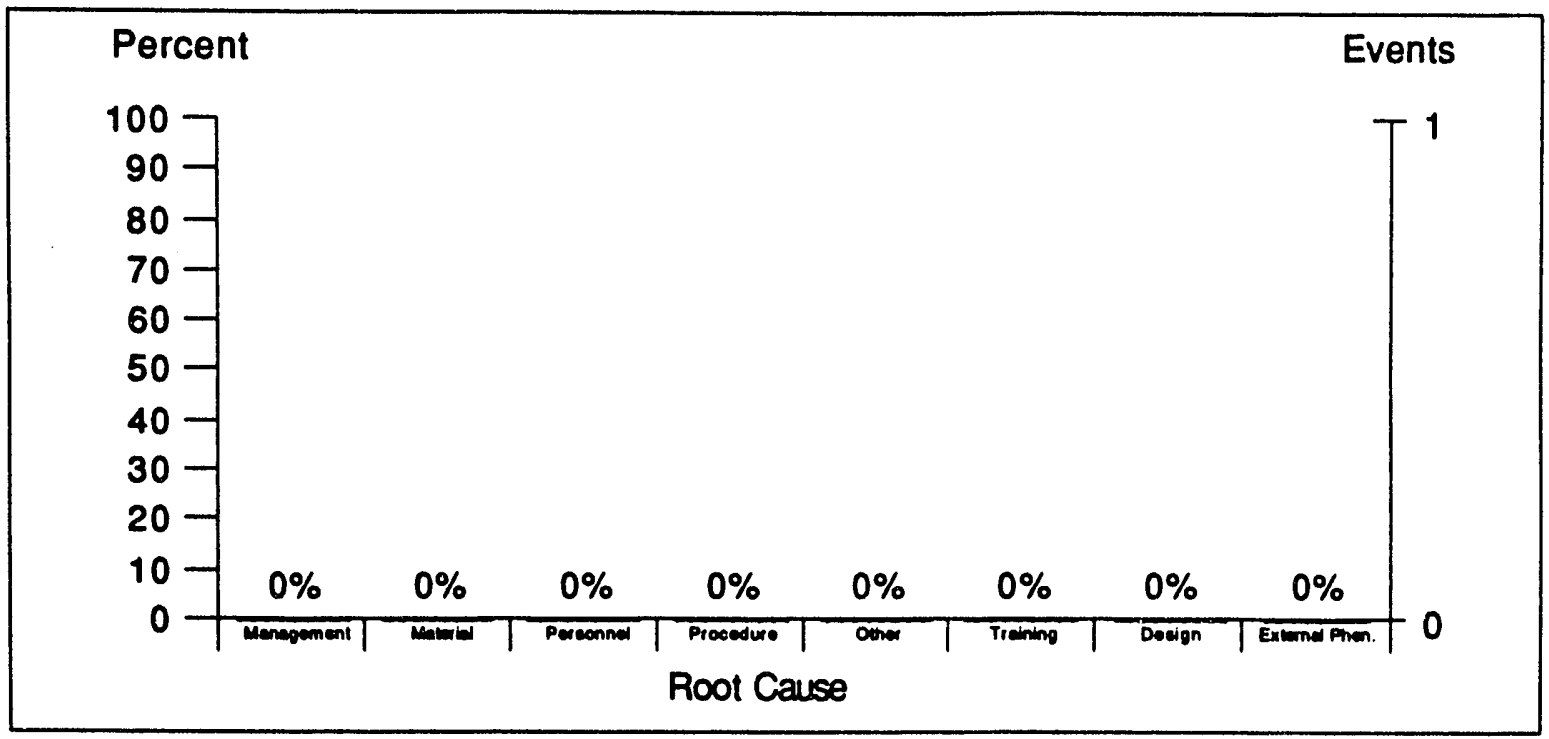

\subsection{Violations of Operating Procedures}

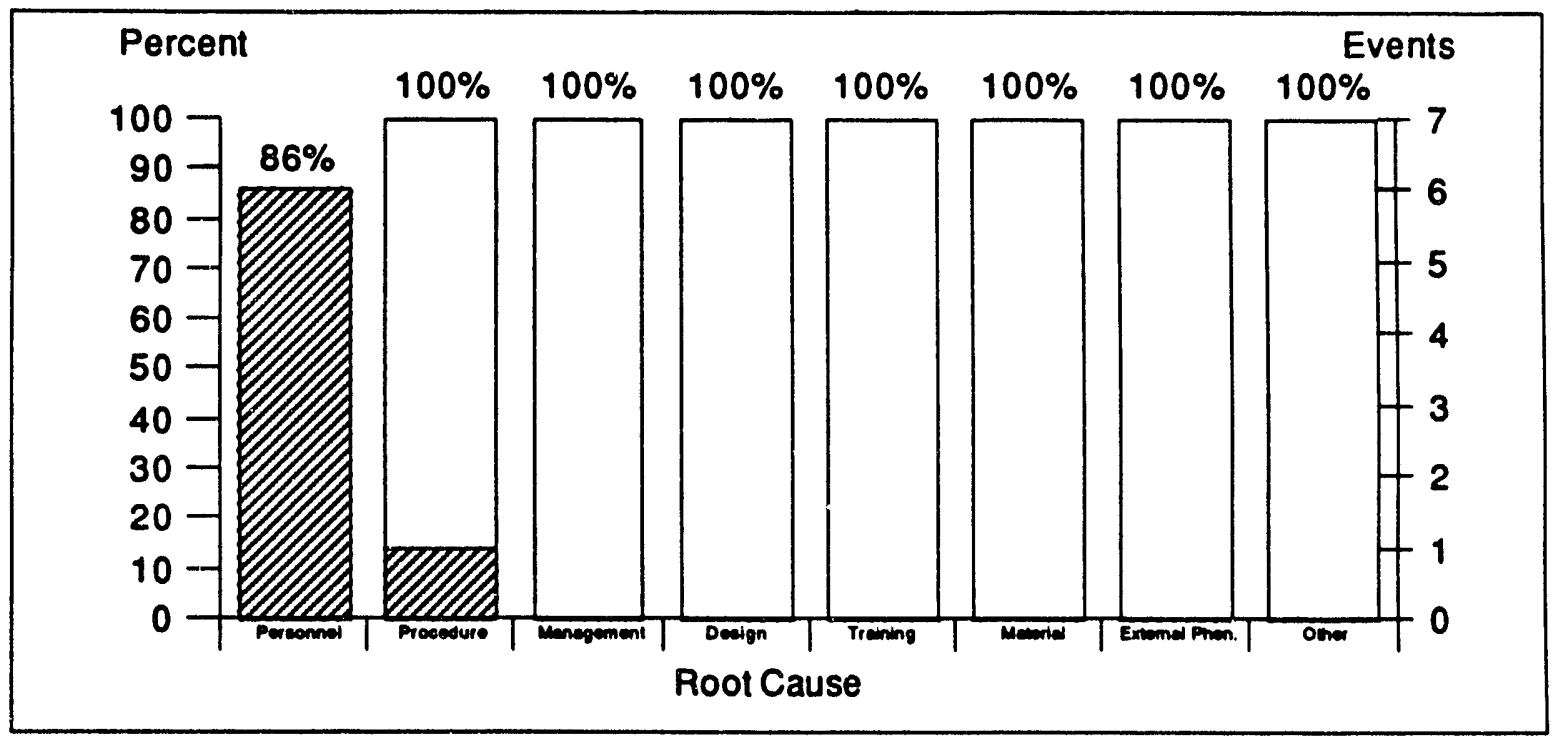


DOE Performance Indicators - EG\&G Idaho. Inc. Overview by $P$ 1st Quarter CY93

\subsection{Unplanned Shutdowns}

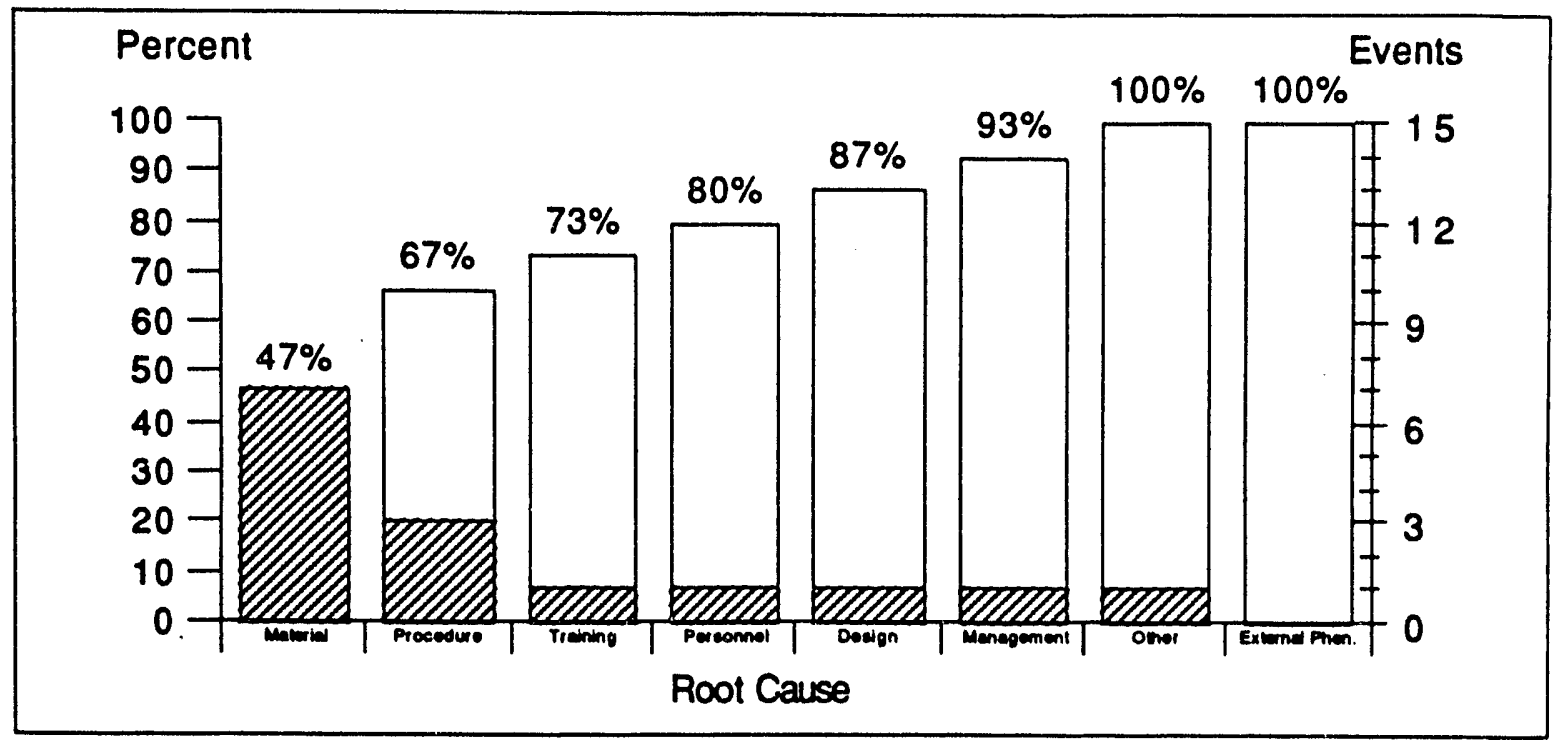

\subsection{ENVIRONMENT}

\subsection{Environmental Incidents}

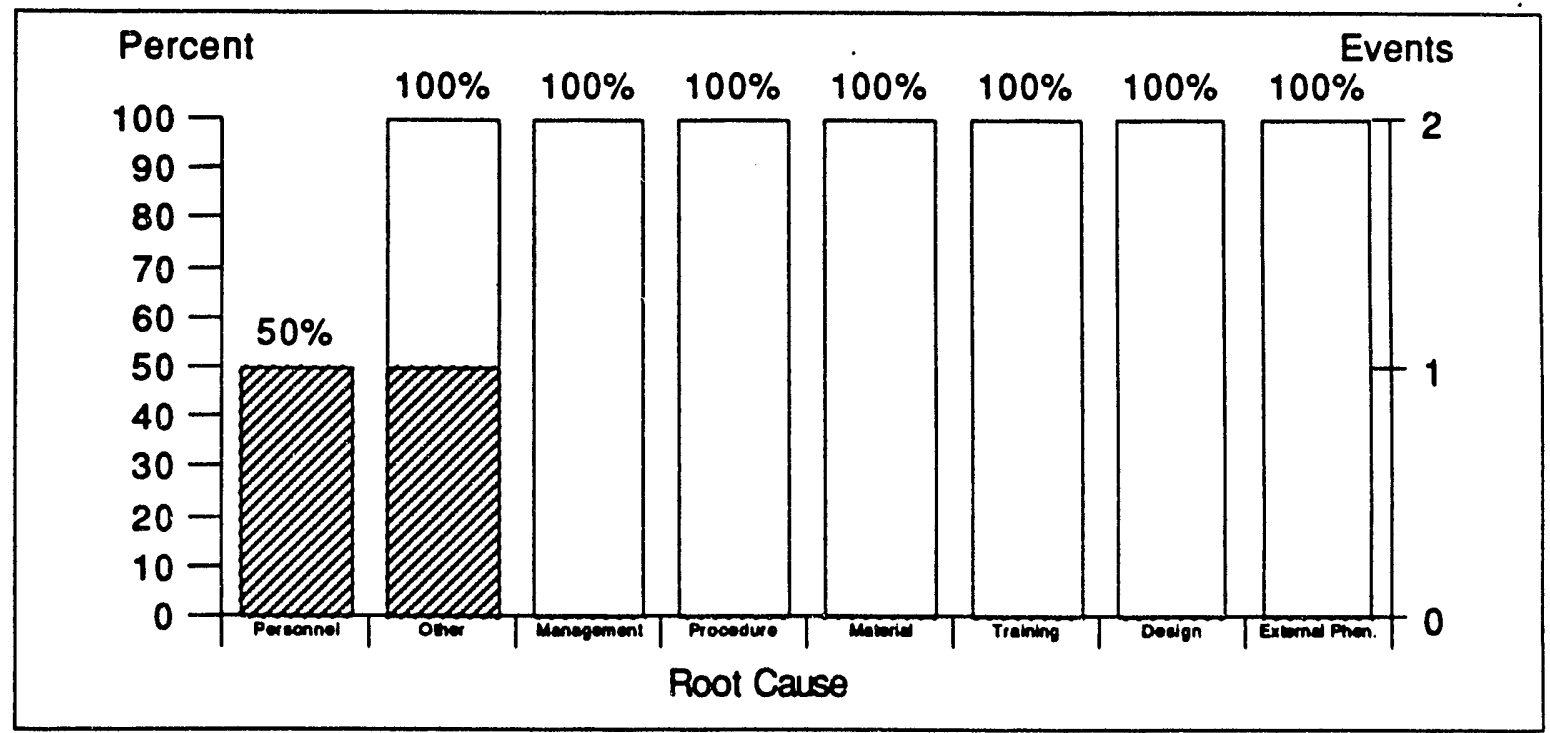


Overvlew by $P I$ DOE Performance Indicators - EG\&G Idahe. Inc. 1 st Quarter CY93 


\section{Appendix A - Summary of Performance by Performance Indicator}

This appendix is intended to provide analysis summaries and conclusions pertinent to EG\&G facility/contractor performance for each performance indicator. As with the past eight reports, this report is based on limited historical contractor and facility data and therefore includes little trending information. Additional trending analysis and conclusions will be provided in future quarterly reports as the historical data base grows. In many cases, the indicators are influenced primarily by the operational status of the facilities.

\subsection{PERSONNEL SAFETY}

\section{Collectlve Radlation Dose (Facility Total)}

The decrease in shallow dose radiation exposures reflects the types and quantity of outage work at the ATR during the first quarter of 1993. The radiation exposures remain at levels below the ALARA goals for the year.

The decrease in deep dose radiation exposures reflects the types and quantity of outage work at the ATR during the first quarter of 1993 . The radiation exposures remain at levels below the ALARA goals for the year.

Trending and bounds (upper and lower control limits) for these indicators have little, if any meaning. This is due to the operational/maintenance cycles of the ATR influencing the radiation exposure.

\subsection{Skin/Clothing Contaminations (Facility Total)}

Only a single skin/clothing contamination event occurred during the first quarter of 1993 at the EG\&G facilities. The event occurred at the TRA Hot Cells and was attributable to inadequate procedures resulting in several particles being picked up on a worker's company furnished clothes during the discharge of a sample from the Hot Cells (ID--EGG-TRAHC-1993-0002).. The relatively low number of skin contamination events is reflective of the increased EG\&G radiological control activities.

\subsection{Internal Contaminatlons (Facility Total)}

No internal contamination events occurred at any of the EG\&G facilities during the first quarter of 1993.

\subsection{Radloactive Or Hazardous Materlal Overexposures (Facility Total)}

No radioactive or hazardous material overexposures occurred at any of the EG\&G facilities during the first quarter of 1993.

\subsection{Lest Work Day Case Rate (Contractor Total)}

Although eighteen lost work day events occurred at EG\&G facilities during the first quarter of 1993, the lost work day case rate dropped from 1.72 events/100 person years in the fourth quarter of 1992 to 1.58 events $/ 100$ person years in the first quarter of 1993. This compares to an average lost time accident rate (including lost and restricted work days) of 1.7 for the DOE system ${ }^{\mathrm{a}}$, and 4.1 for U.S. industry regulated by OSHAb. The majority of these events are strains $(65 \%)$ and cumulative trauma disorders $(12 \%)$. The EG\&G goal for the lost work day case rate for FY -93 is 1.29 events/100 person years.

\subsection{Recordable Iniuryllilness Rate (Contractor Total)}

Although 43 injury/illness cases occurred at EG\&G facilities during the first quarter of 1993, the injury/iliness rate dropped from 4.16 events/100 person years in the fourth quarter of 1992 to 3.77 cases/100 person years in the first quarter of 1993. This compares to an average injury/illness rate of 3.7 for the DOE system ${ }^{a}$, and 8.8 for U.S. industry regulated by OSHA ${ }^{b}$. The majority of these cases are strains $(36 \%)$ and cumulative trauma disorders $(29 \%)$. The EG\&G goal for the recordable injuryfillness rate is 3.18 events/100 person years.

a. Source: Occupational Injury and Property Damage Summary Repont, January - December 1992, Office of Safety and Quality Assurance.

b. Source: National Salety Council, The Accident Facts, 1992 edition. 


\subsection{OPERATIONAL INCIDENTS}

\subsection{Unplanned Safety Function Actuations (Facility Total)}

- No unplanned safety function actuations occurred at any of the EG\&G facilities during the first quarter of 1993.

\subsection{Vielations of Operating Procedures (Facility Total)}

The number of violations of operating procedures increased from two events in each of the four previous quarters to three violations at the EG\&G facilities in the first quarter of 1993. All three violations occurred at the ATR and involved 1) the improper mounting of an experimental loop pump base (ID--EGG-ATR-19930004); 2) a failure to fully understand and perform a loop shutdown test (ID--EGG-ATR-1993-0008); and 3) the inadvertent removal of a check source (ID--EGG-ATR-1993-0009). The increase from two to three violations is not significant and can not be attributed to any generic cause.

\subsection{Unplanned Shutdowns (Facility Total)}

The number of unplanned shutdowns at EG\&G facilities remained at three for the first quarter of 1993. All three of the first quarter unplanned shutdowns occurred at the ATR with two of the three reactor shutdowns resulting from equipment failures. One of the equipment failures was a manually initiated shutdown of the ATR when the reactor control cylinders failed to function normally (ID--EGG-ATR-1993-0006) and was also reported as an Unusual Occurrence (PI 2.4). The other equipment failure involved the failure of an experimental loop instrument (ID--EGG-ATR-1993-0005). The third ATR outage was a reactor scram initiated from an experimental loop as a result of an operator error due to a training deficiency (ID-.-EG\&G. 1993-0001).

\section{Emergency And Unusual Qccurrences (Facility Total)}

A single Unusual Occurrence Report (UOR) was issued by the EG\&G facilities during the first quarter of 1993. The single UOR was the result of an equipment failure which necessitated a manual shutdown of the ATR when the reactor control cylinders failed to function normally (ID--EGG-ATR-1993-0006). This was also reported as an unplanned shutdown (PI 2.3).

\subsection{Substance Abuse incidents (Contractor Total)}

No substance abuse incidents occurred at EG\&G during the first quarter of 1993.

\subsection{ENVIRONMENT}

\subsection{Radlonucllde Effluent (Facility Total)}

The majority of the airborne effluent is from the ATR nuclear fission reactor and is due to the activated argon-41 in the low pressure, low temperature primary coolant system water. The activated argon has a short half-life of 1.82 hours. An ATR design change in process will delay the release of argon allowing a substantial amount to decay betore being released. Even though the ATR experienced increased megawatt-day production (power and on-stream time), the slightly lower releases during the first quarter of CY 1993 were due to the previous higher releases due to a pinhole leak in the cladding of a fuel element in Cycle 98B-1 during the fourth quarter of 1992.

The liquid radioactive effluent release is from the ATR nuclear fission reactor and is due to the tritium (96\%) in the primary coolant system water. The tritium levels are expected to continue to increase due to the beryllium reflector continuing its predicted aging and cracking. The higher releases during the first quarter of CY 1993 were due to increased megawatt-day production (power and on-stream time).

Trending and bounds (upper and lower control limits) for these indicators have little, if any meaning. This is due to the operationalmaintenance cycles of the ATR influencing the radiation releases. 


\subsection{Hazardous Substance/Requlated Pollutant Effluent (Facility Total)}

No airborne or liquid hazardous substances or regulated pollutants were released by any of the EG\&G facilities during the first quarter of 1993.

\subsection{Environmental Incidents (Facility Total)}

No environmental incidents occurred at any of the EG\&G facilities during the first quarter of 1993.

\subsection{Solld Low Level Waste Generated (Facility Total)}

The amount of low level radioactive waste generated in this reporting period decreased primarily due to concentrated efforts during the fourth quarter of 1992 by the ATR to collect, characterize, and ship waste from various ATR accumulation areas. In addition, the fourth quarter of 1992 also contained the low level radioactive waste that was generated by RWMC due to decontamination activities at the Certified and Segregated Waste Storage Building. The low level hazardous waste that was generated in the first quarter of CY 1993 was three industrial lead acid batteries from the RWMC that were returned for recycling. No mixed waste was generated at any of the EG\&G facilities during the first quarter of 1993.

\subsection{MANAGEMENI}

\subsection{DOE Audit Issues (Contractor Total)}

This indicator was previously defined as a facility total of the number of open DOE Audit Issues at the end of the quarter. It is now defined as a contractor total of the number of DOE Audit Issues that have been open greater than 90 days at the end of the quarter. It was not possible to backfit data for this indicator as the information has been kept at the facilities and only as the number of issues open rather than the number of issues open greater than 90 days. Therefore, data are only presented in this report for first quarter 1993. A total of 199 contractor issues that had been open greater.than 90 days at the end of the first quarter were identified. Trend determinations will be made once sufficient data exist for this indicator as currently defined.

\subsection{External Organization_lssues (Contractor Total)}

The two open external organization recommendations were identified at RWMC during the Waste Isolation Pilot Plant (WIPP) audits by the Waste Acceptance Criteria Certification Committeo (WACCC) in the third quarter of 1991. This PI was previously a facility total of the number of open External Organization Issues at the end of the quarter. It is now a contractor total of the number of External Organization Issues that have been open greater than 90 days at the end of the quarter. No additional issues were identified when this indicator became a contractor total. However, the data for the third quarter of 1991 is now 0 instead of 2 , since these issues had not yet been open greater than 90 days.

\subsection{OSH Noncompllance (Facility Total)}

The definition for the OSH Noncompliance PI was changed from the number of OSH violations identified at the facilities during the quarter to the number of OSH noncompliances open greater than 90 days for the contractor at the end of the quarter. It was not possible to backfit this indicator as the information has been kept at the facilities and only as the number of issues identified during the current quarter rather than the number of issues open greater than 90 days. Additionally, no company level system exists to track the information as currently required. Therefore, reporting for this indicator will continue to be a facility total until such time as a system is in place to track these issues at a company level. It is currently planned to have a tracking system in place and functional by the first quarter of 1994. For first quarter 1993, 131 issues remained open greater than 90 days at the end of the quarter . 


\subsection{Correctlve Malntenance Backlea (Facility Total)}

During the fourth quarter of 1992 at EG\&G facilities, there were $142 \mathrm{CM}$ items open greater than three months versus a total of 413 open (34\%). For the first quarter of 1993, the total number of open itoms increased to 423 , with $237 \mathrm{CM}$ items open longer than three months $(56 \%)$. The corrective maintenance backlog increased during the first quarter of 1993 because the ATR assigned priority work towards the preparation for the Process Control Upgrade outage in the second quarter of 1993.

\subsection{Preventlve Maintenance Qverdue (Facility Total)}

During the fourth quarter of 1992 at EG\&G facilities, 3.04\% of the scheduled PM items were not completed within the originally scheduled interval (25 of 822). For the first quarter of $1993,4.05 \%$ of the scheduled PM items were not completed within the originally scheduled interval (24 of 592).

\subsection{Occurrence Reports With Open Correctlve Actlons (Facility Total)}

At the close of the first quarter, 24 Final Occurrence Reports (ORs) had open corrective actions at EG\&G facilities (ATR-14, RWMC-6, and WERF-4). The increased number of occurrence reports reflects the increased emphasis on finalizing ORs. 


\section{Appendix B - Performance Indicator Charts for the ATR Facility}

This appendix provides charts and descriptions of performance indicators for the ATR facility performance. The performance indicators are identified consistent with the numbering in DOESTD-1048-92. Note that PIs 1.5, 1.6, 2.5, 4.1, and 4.2 are only reported at the contractor level and are not included in the facility appendices.

\subsection{PERSONNEL SAFETY}

\subsection{Collective Radiation Dose}

\subsubsection{Shallow Dose}

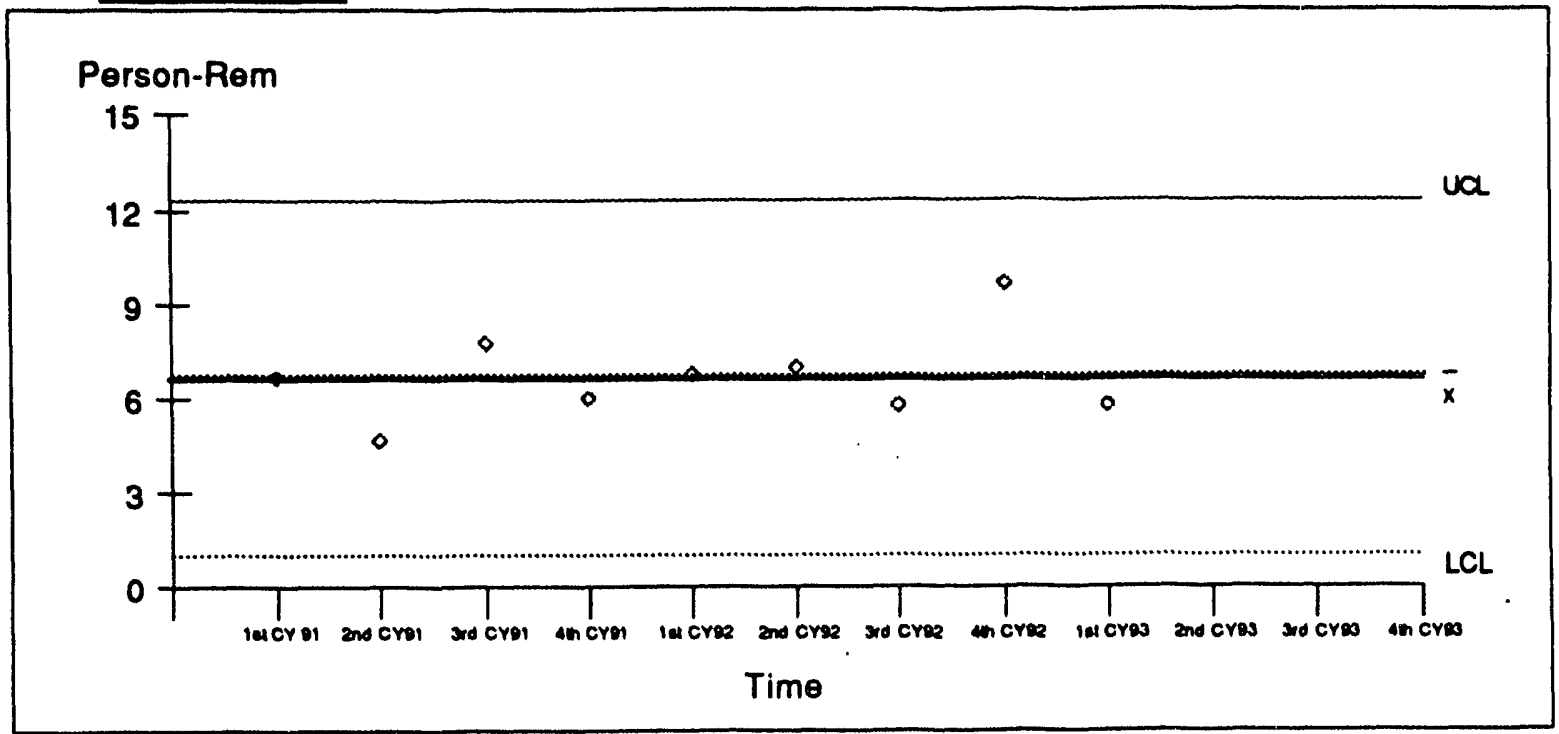

- The decrease in shallow dose radiation exposures reflects the types and quantity of outage work at the ATR during the first quarter of 1993. The radiation exposures remain at levels below the ALARA goals for the year.

\subsubsection{Deep Dose}

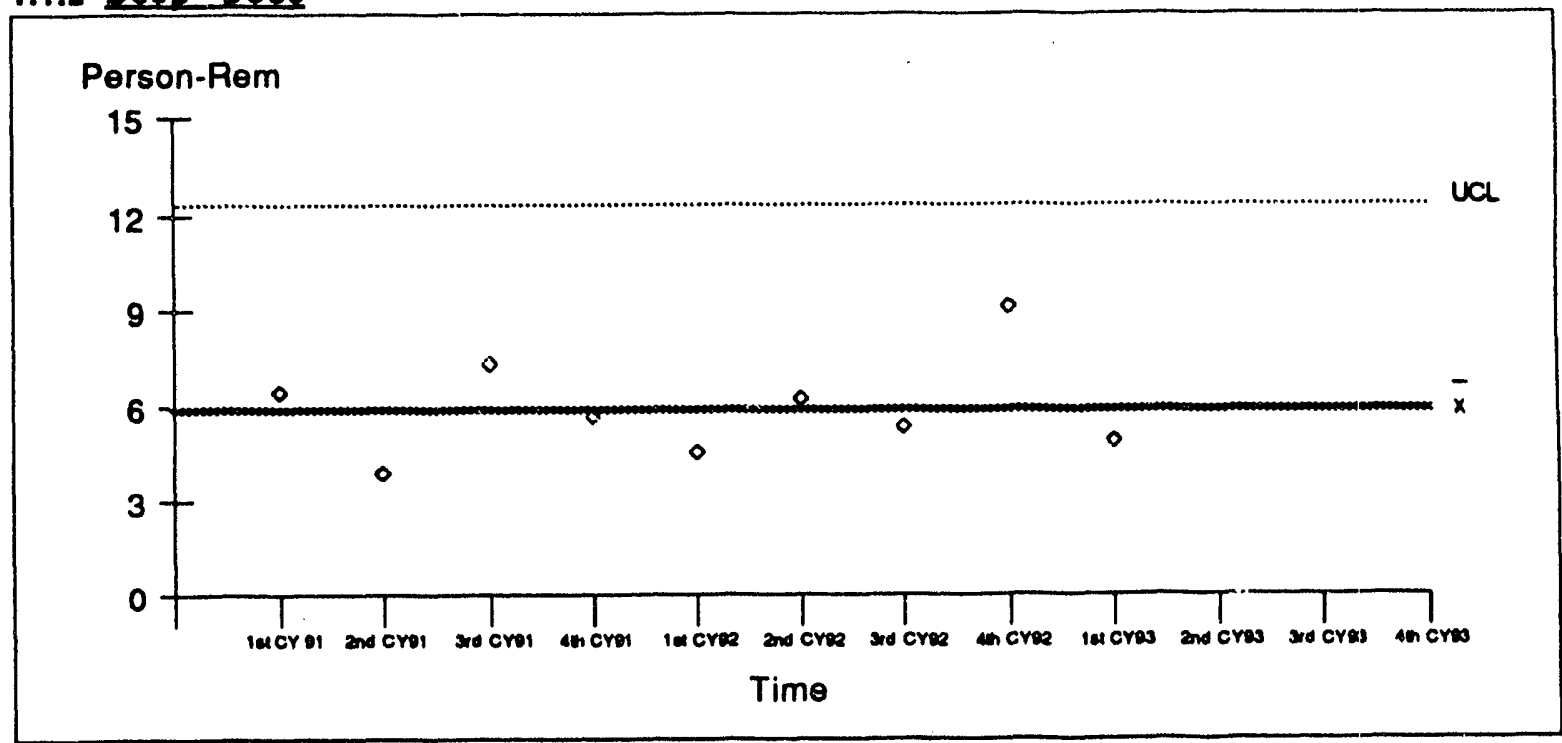

- The decrease in deep dose radiation exposures reflects the types and quantity of outage work at the ATR during the first quarter of 1993. The radiation exposures remain at levels below the ALARA goals for the year. 


\section{Skiniclothing Contaminations}

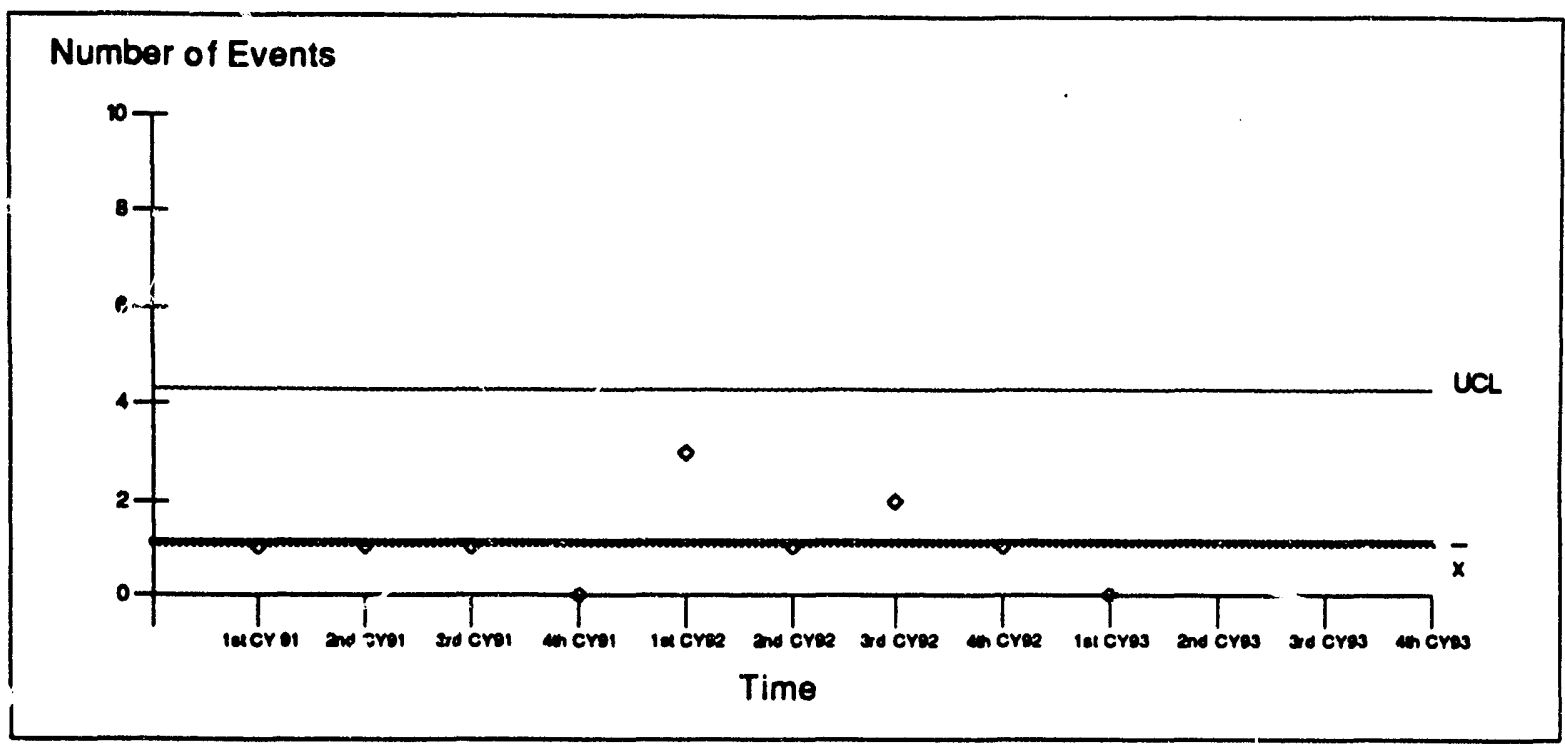

- No skin/clothing contamination events occurred at the ATR during the first quarter of 1993.

\subsection{Internal Contaminations}

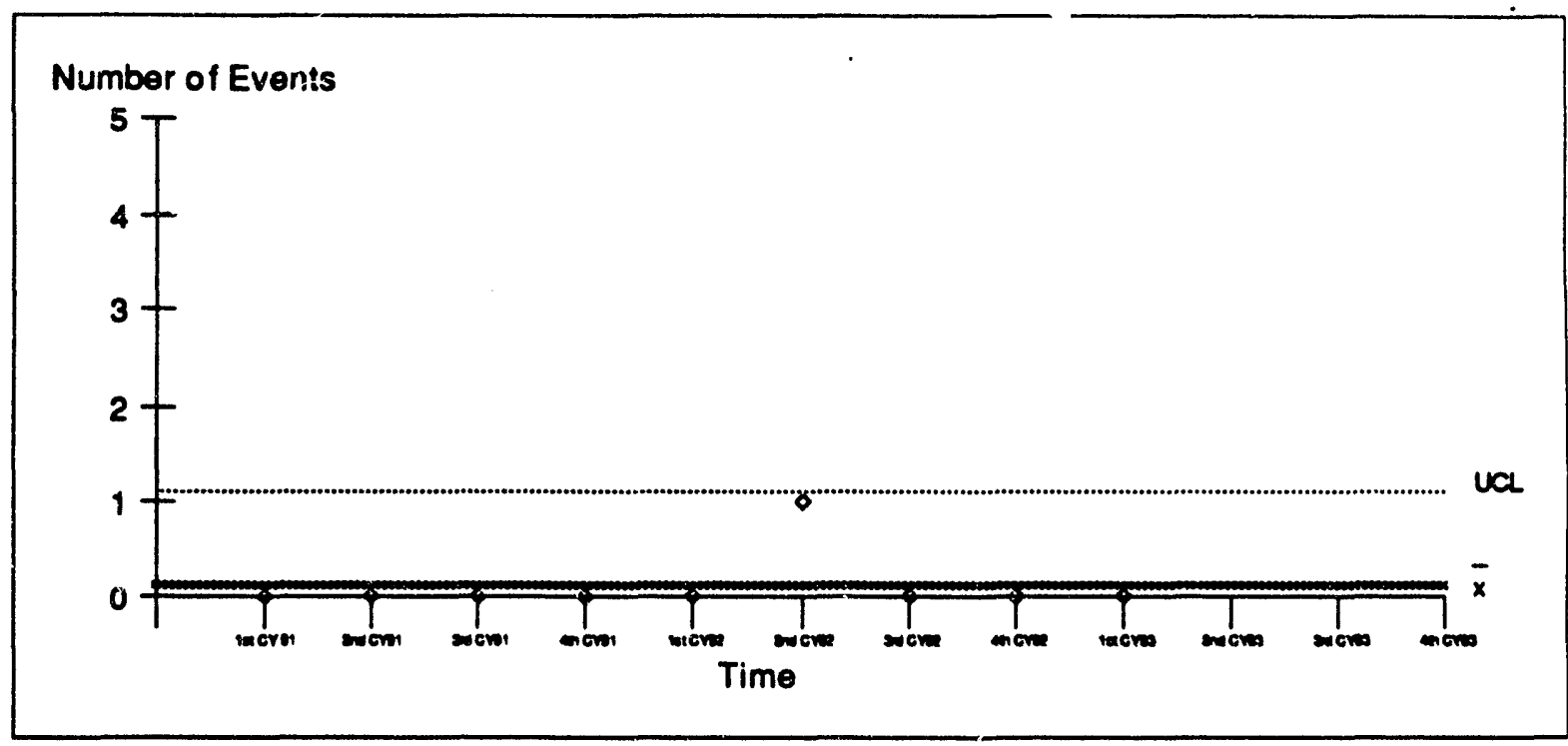

- No internal contamination events occurred at the ATR during the first qLi irter of 1993. 
DOE Performance Indicators - EG\&G Idaho. Inc. Appendix B Performance Indicator Charts for the ATR Facility

\subsection{Radloactive Or Hazardous MaterlaL Overexposures}

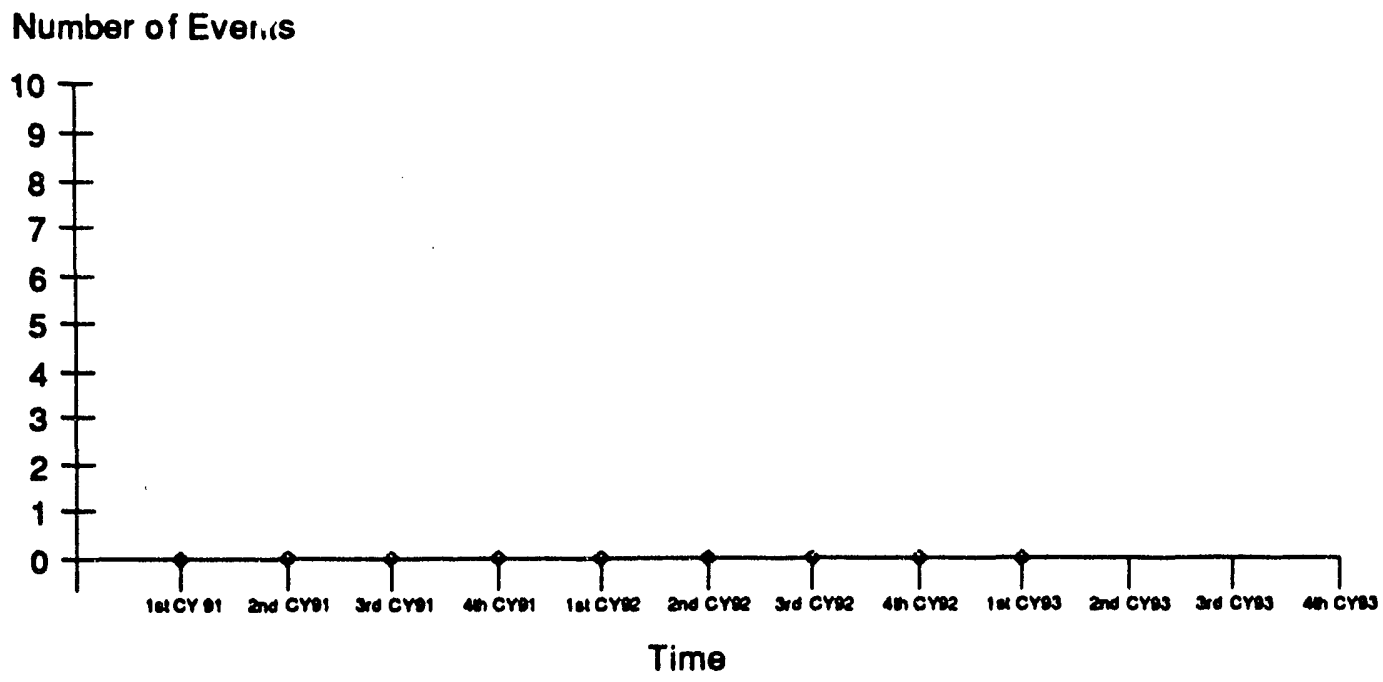

- No radicuactive or hazardous material overexposures occurred at the ATR during the first quarter of 1993. 
Appendix B

Performance Indicator Charts for the ATR Facility

DOE Performance Indicators - EG\&G Idaho. Inc. 


\subsection{OPERATIONAL INCIDENTS}

\subsection{Unplanned Safety Function Actuations}

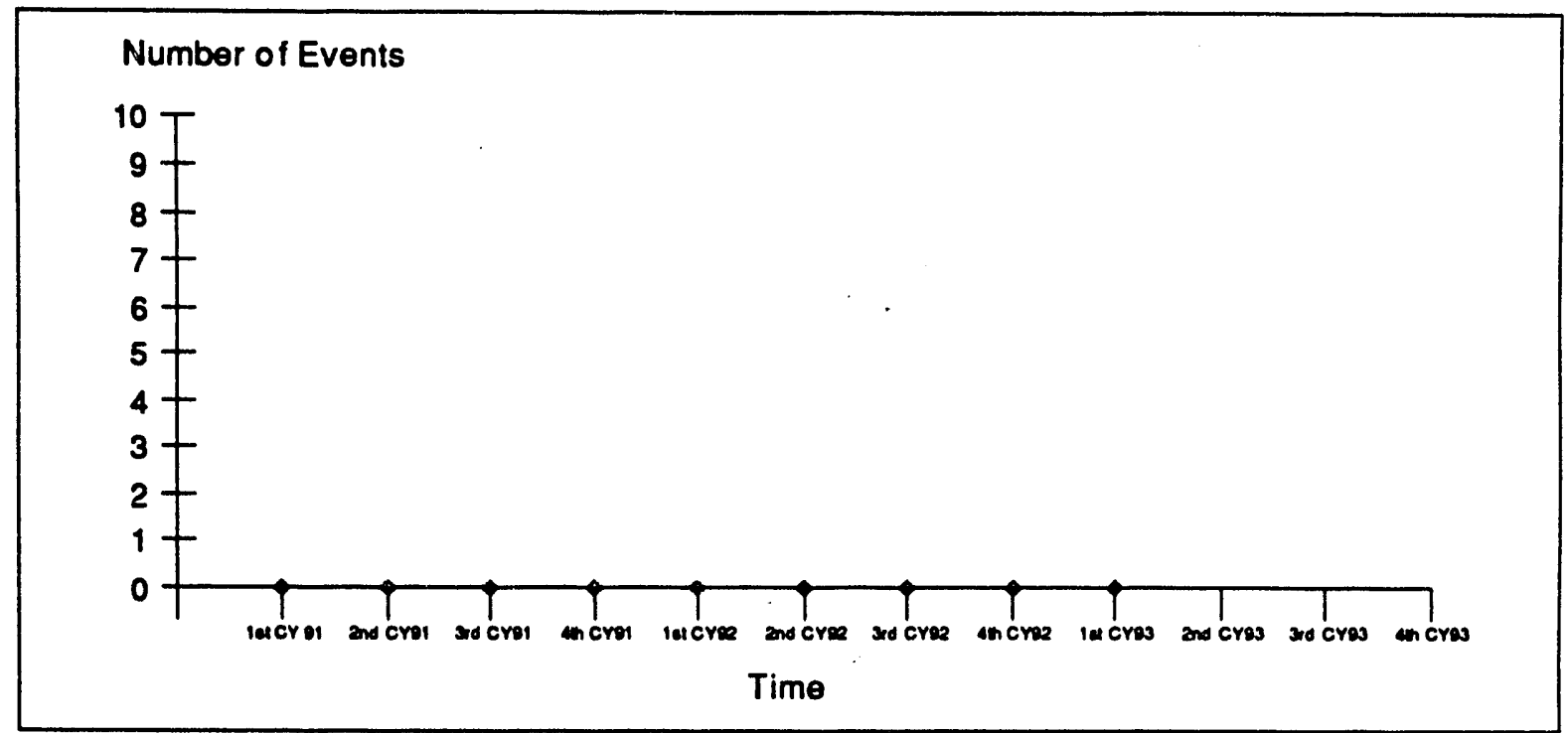

- No unplanned safety function actuations occurred at the ATR during the first quarter of 1993.

\subsection{Violations of Operating Procedures}

Number of Events

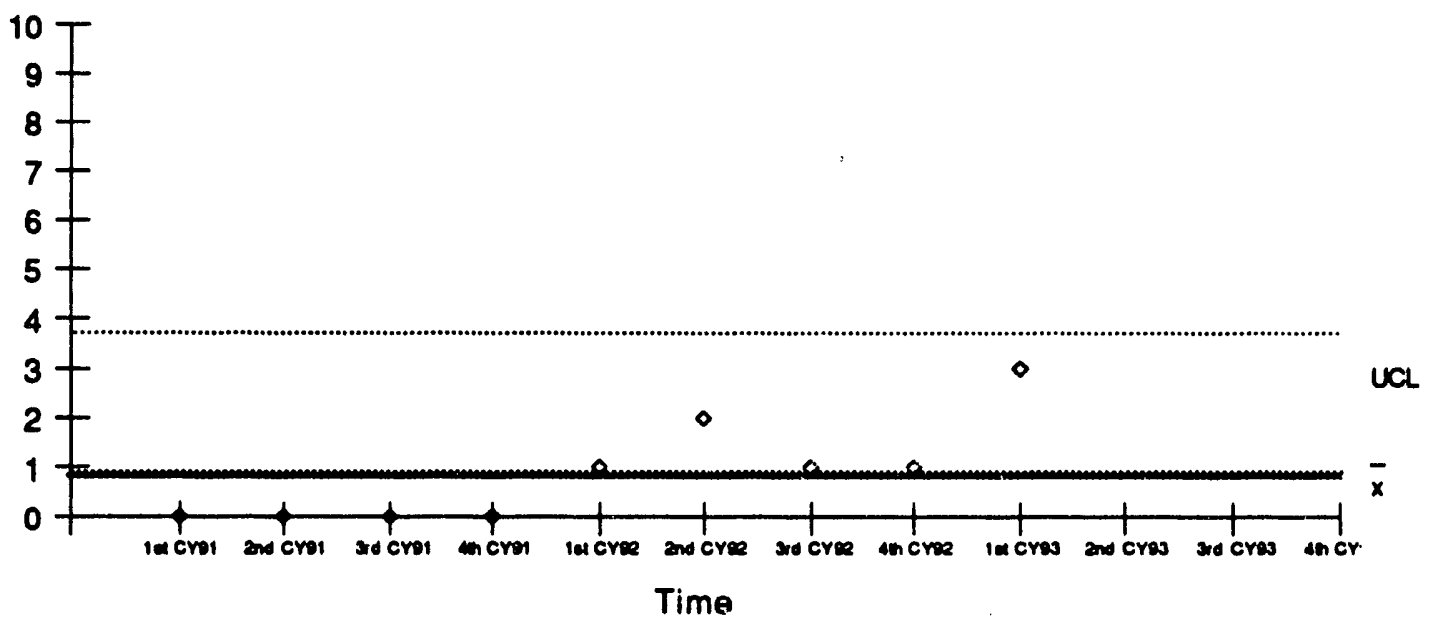

- The number of violations of operating procedures increased from one event in the previous two quarters to three violations at the ATR in the first quarter of 1993 . The three violations involved 1) the improper mounting of an experimental loop pump base (ID--EGG-ATR-1993-0004); 2) a failure to fully understand and perform a loop shutdown test (ID--EGG-ATR-1993-0008); and 3) the inadvertent removal of a check source (ID--EGG-ATR-1993-0009). The increase from one to three violations is not significant and can not be attributed to any generic cause. 


\subsection{Unplanned Shutdowns}

Number of Events

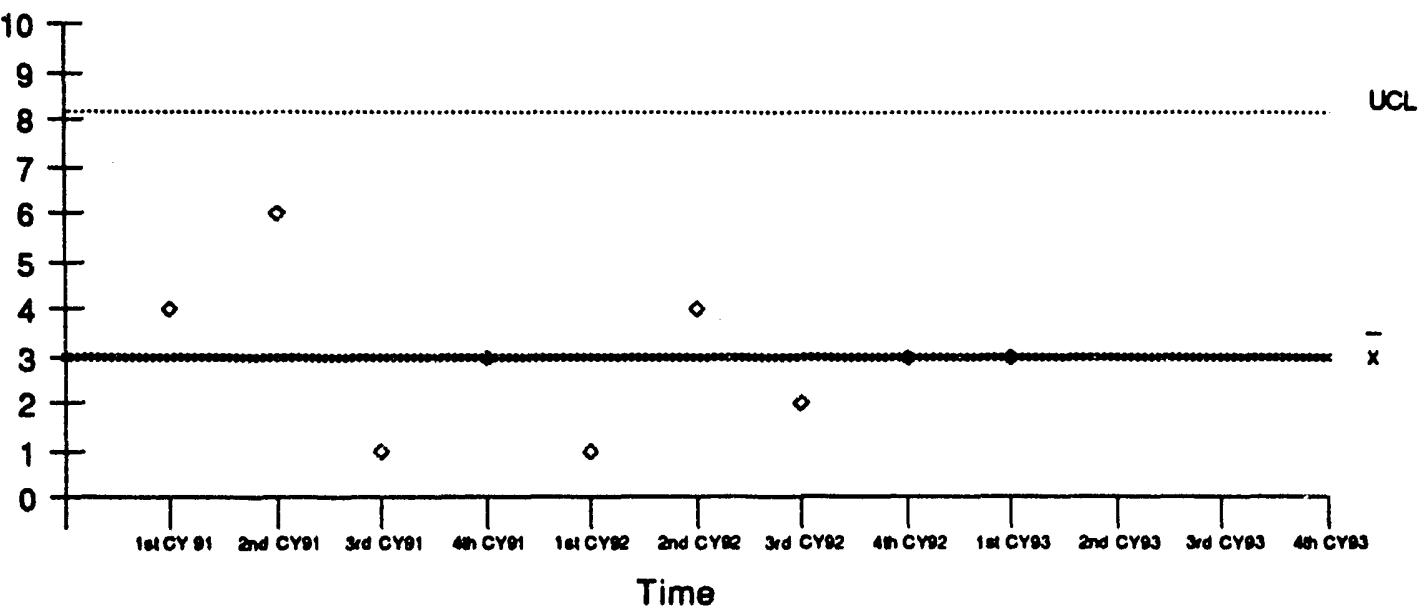

- The number of unplanned shutdowns at the ATR remained at three for the first quarter of 1993. Two of the three reactor shutdowns resulted from equipment failures. One of the equipment failures was a manually initiated shutdown of the ATR when the reactor control cylinders failed to function normally (ID--EGG-ATR1993-0006) and was also reported as an Unusual Occurrence (PI 2.4). The other equipment failure involved the failure of an experimental loop instrument (ID--EGG-ATR-1993-0005). The third ATR outage was a reactor scram initiated from an experimental loop as a result of an operator error due to a training deficiency (ID--EG\&G-1993-0001).

\subsection{Emeraency And Unusual Occurrences}

\section{Number of Events}

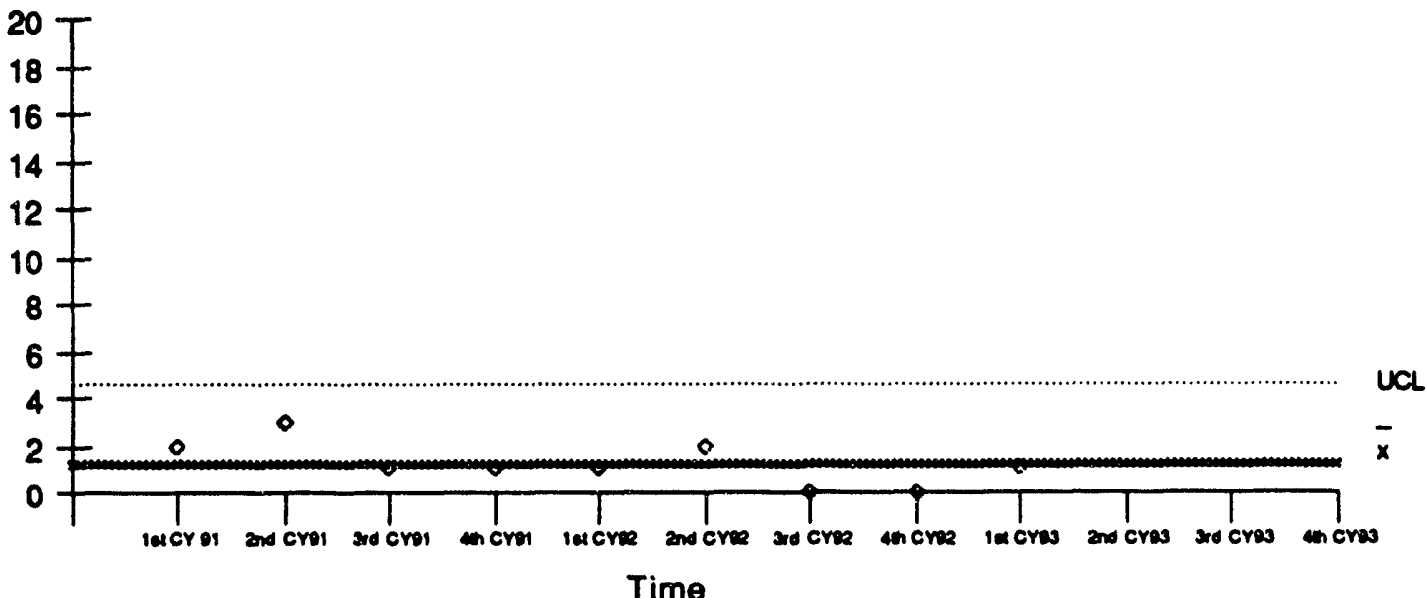

Time

A single Unusual Occurrence Report (UOR) was issued by the ATR during the first quarter of 1993. The single UOR was the result of an equipment failure which necessitated a manual shutdown of the ATR when the reactor control cylinders failed to function normally (ID--EGG-ATR-1993-0006). This was also reported as an unplanned shutdown (PI 2.3). 


\subsection{ENVIRONMENT}

\subsection{Radlonucllde Effluent}

\subsubsection{Alrborne}

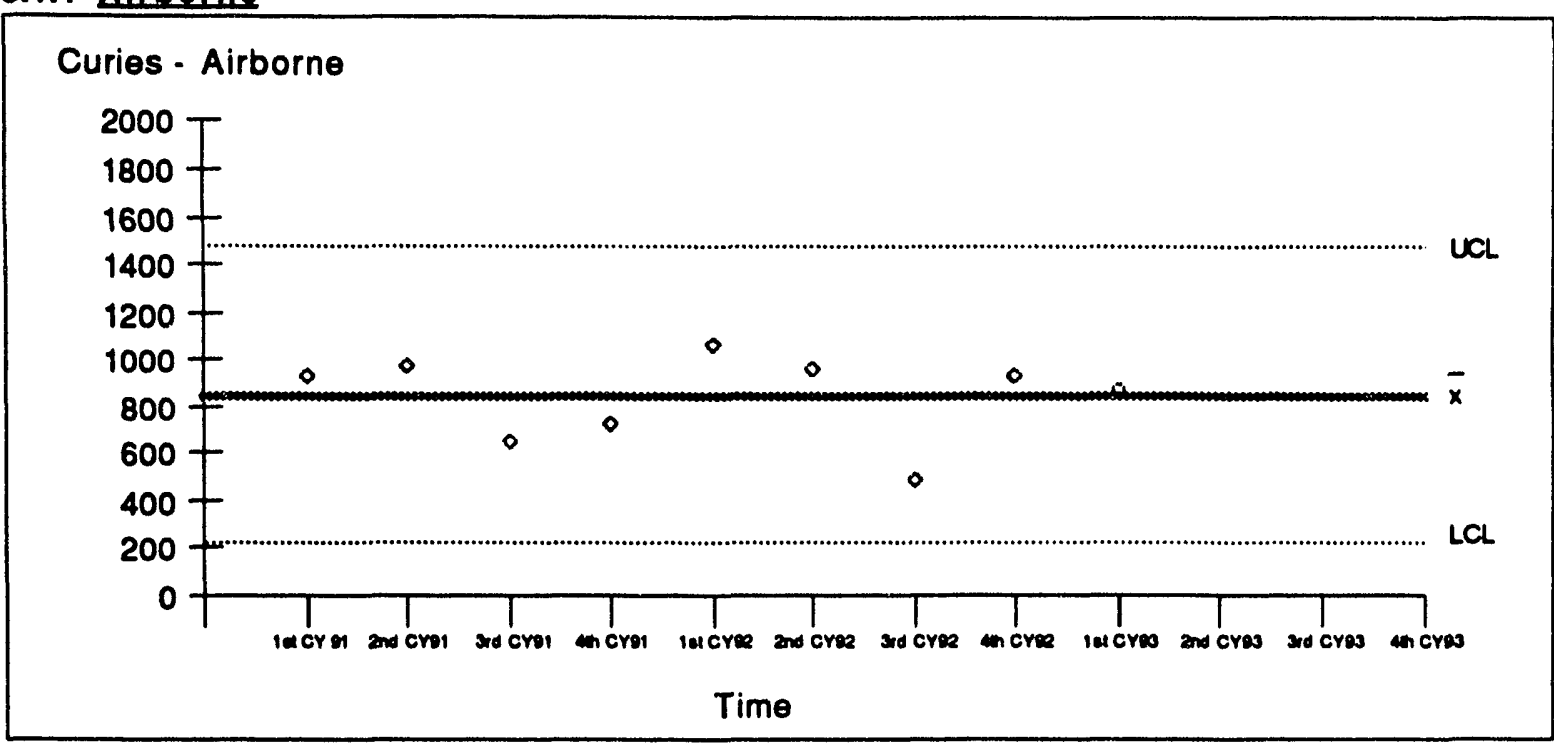

The majority of the aiborne effluent is from the ATR nuclear fission reactor and is due to the activated argon-41 in the low pressure, low temperature primary coolant system water. The activated argon has a short half-life of 1.82 hours. An ATR design change in process will delay the release of argon allowing a substantial amount to decay before being released. Even though the ATR experienced increased megawatt-day production (power and on-stream time), the slightly lower releases during the first quarter of CY 1993 were due to the previous higher releases due to a pinhole leak in the cladding of a fuel element in Cycle 98B-1 during the fourth quarter of 1992.

\subsection{2 hlould}

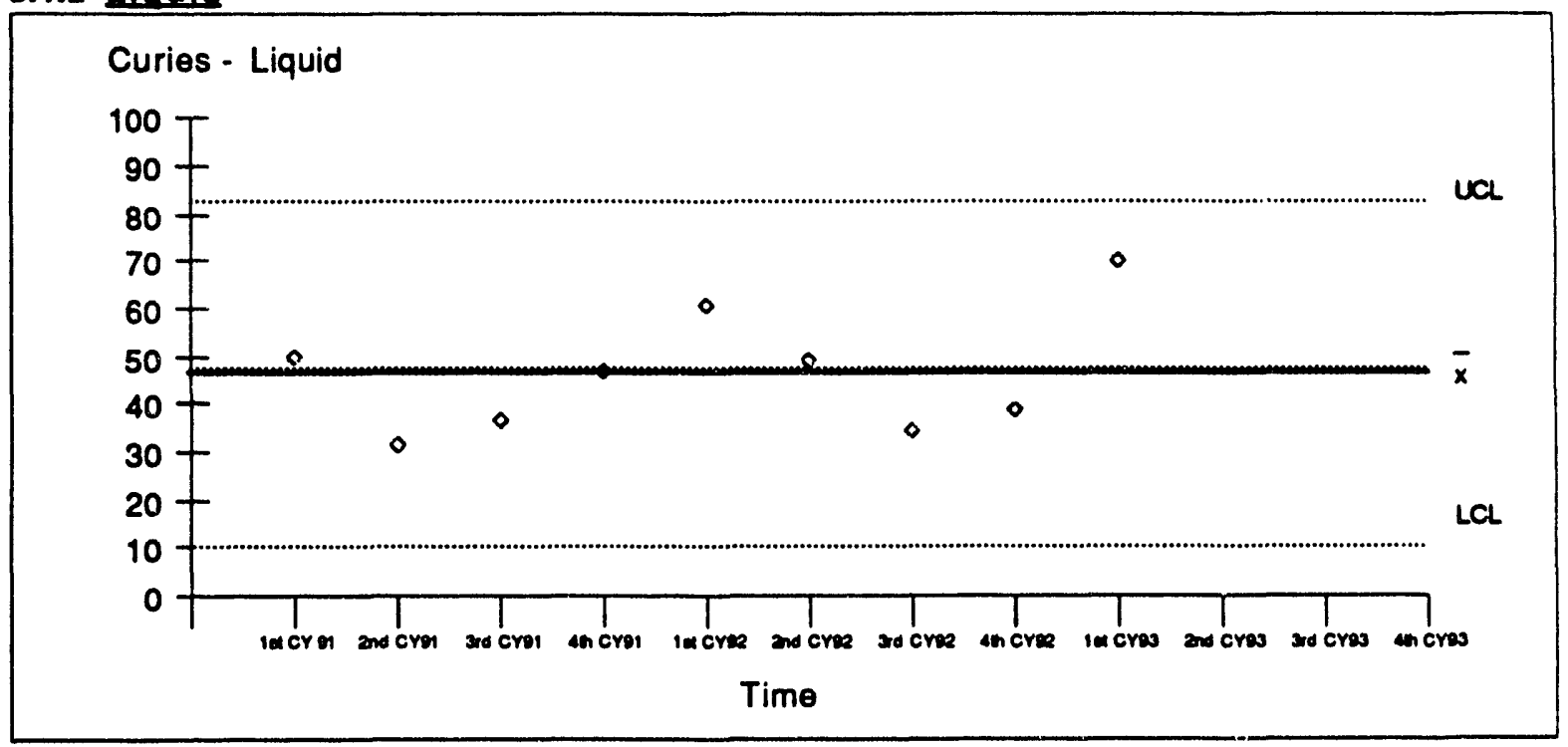

The liquid radioactive effluent release is from the ATR nuclear fission reactor and is due to the tritium (96\%) in the primary coolant system water. The tritium levels are expected to continue to increase due to the beryllium reflector continuing its predicted aging and cracking. The higher releases during the first quarter of CY 1993 were due to increased megawatt-day production (power and on-stream time). 


\subsection{Hazardous Substance/Regulated Pollutant Effluent}

\subsubsection{Alrborne}

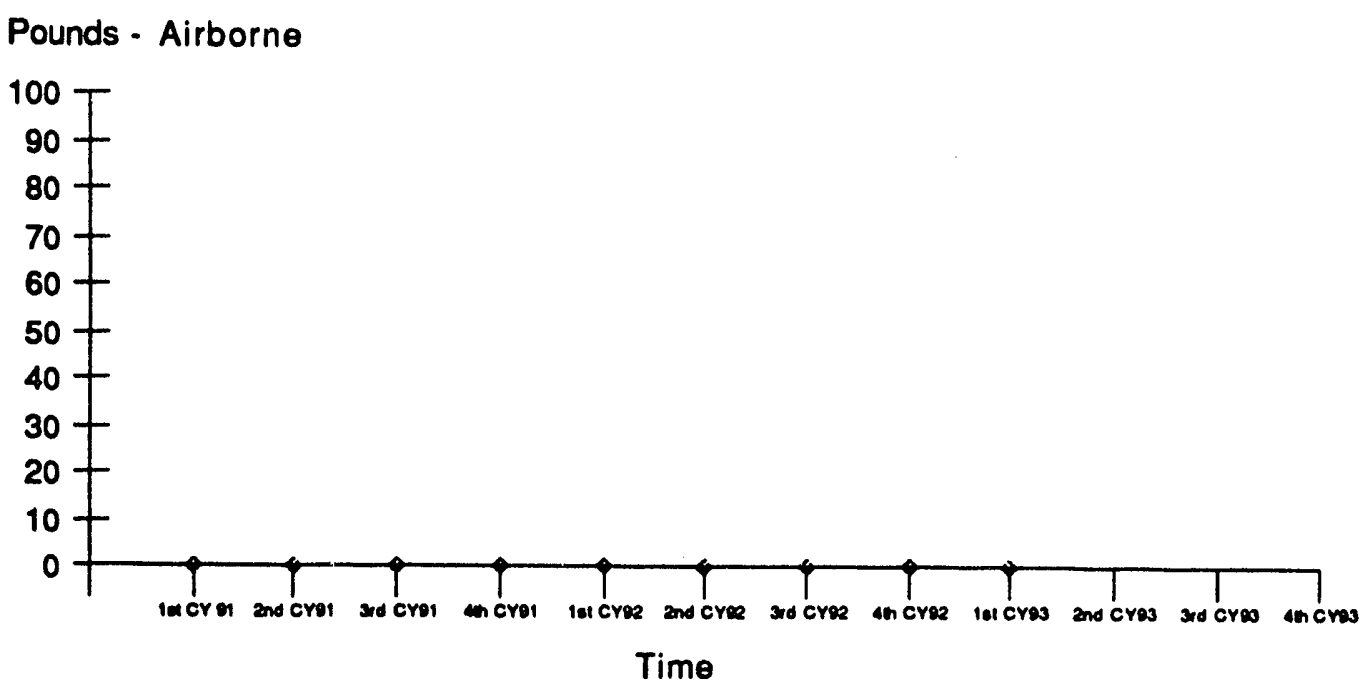

- No airborne hazardous substances or regulated pollutants were released by the ATR during the first quarter of 1993.

\subsubsection{Llauld}

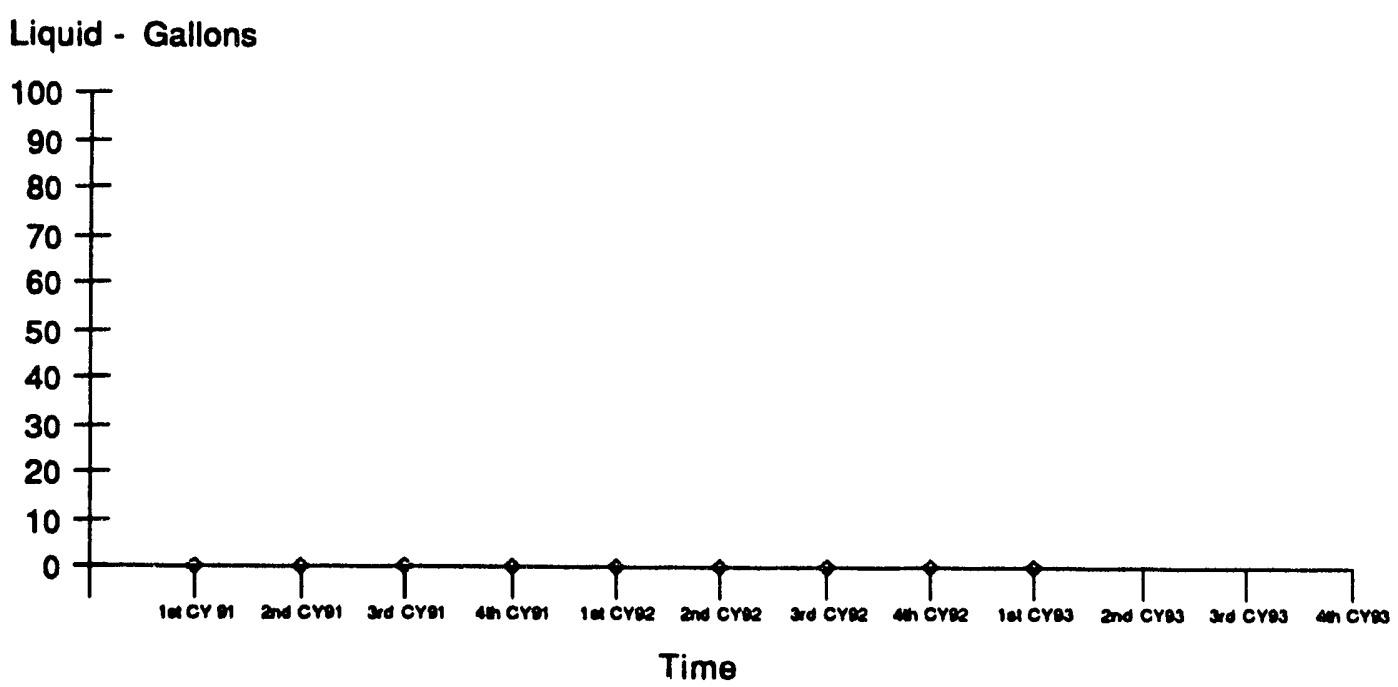

No liquid hazardous substances or regulated pollutants were released by the ATR during the first quarter of 1993. 


\subsection{Environmental Incidents}

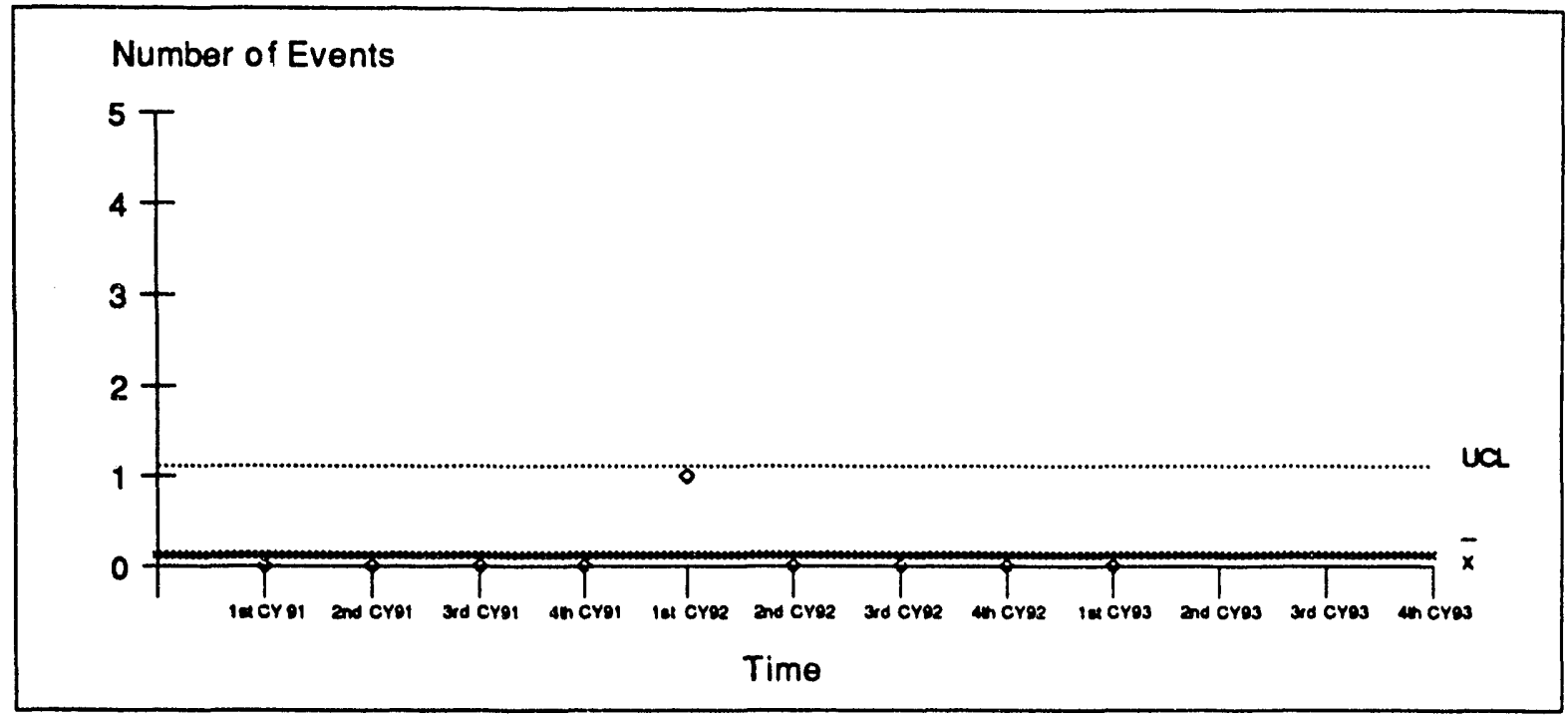

- No environmental incidents occurred at the ATR during the first quarter of 1993.

\subsection{Solld Low Level Waste Generated}

\subsubsection{Radioactive Waste}

Cubic Feot

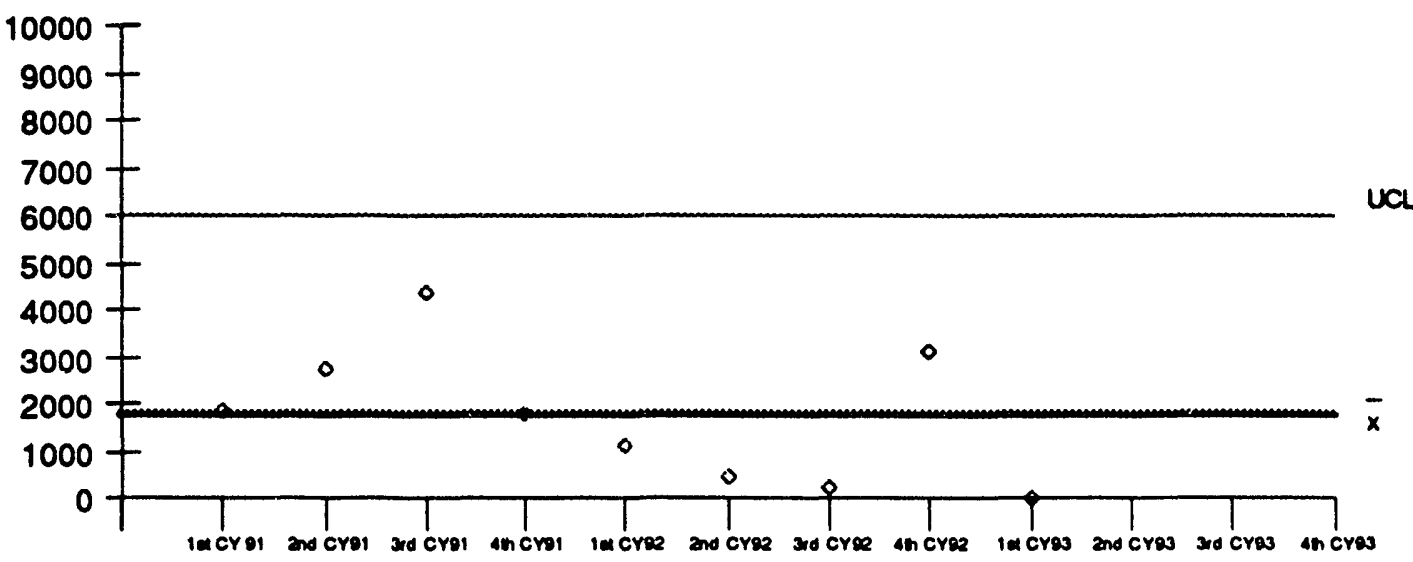

Time

- The amount of low level radioactive waste generated in this reporting period decreased primarily due to concentrated efforts during the fourth quarter of 1992 by the ATR to collect, characterize, and ship waste from various ATR accumulation areas. 


\subsubsection{Hazardous Waste}

\section{Cubic Feet}

$$
\begin{aligned}
& 10 \\
& 9 \\
& 8 \\
& 7 \\
& 7 \\
& 6 \\
& 5 \\
& 4 \\
& 3 \\
& 3 \\
& 2 \\
& 1
\end{aligned}
$$

$7+$

$6+$

$5-$

$4-$

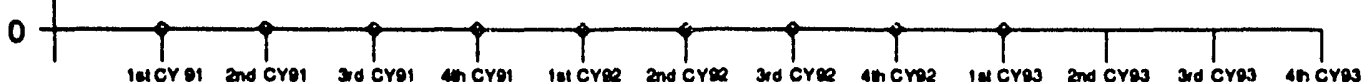

Time

- No low level hazardous waste was generated by the ATR in the first quarter of CY 1993.

\subsubsection{Mlxed Woste}

\section{Cubic Feet}

$\begin{aligned} & 10 \\ & 9 \\ & 8 \\ & 7 \\ & 6 \\ & 5 \\ & 4 \\ & 3 \\ & 2 \\ & 1 \\ & 0\end{aligned}-$

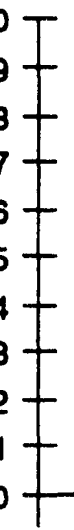




\subsection{MANAGEMENT}

\subsection{OSH Noncompllances}

\section{Number of Events}

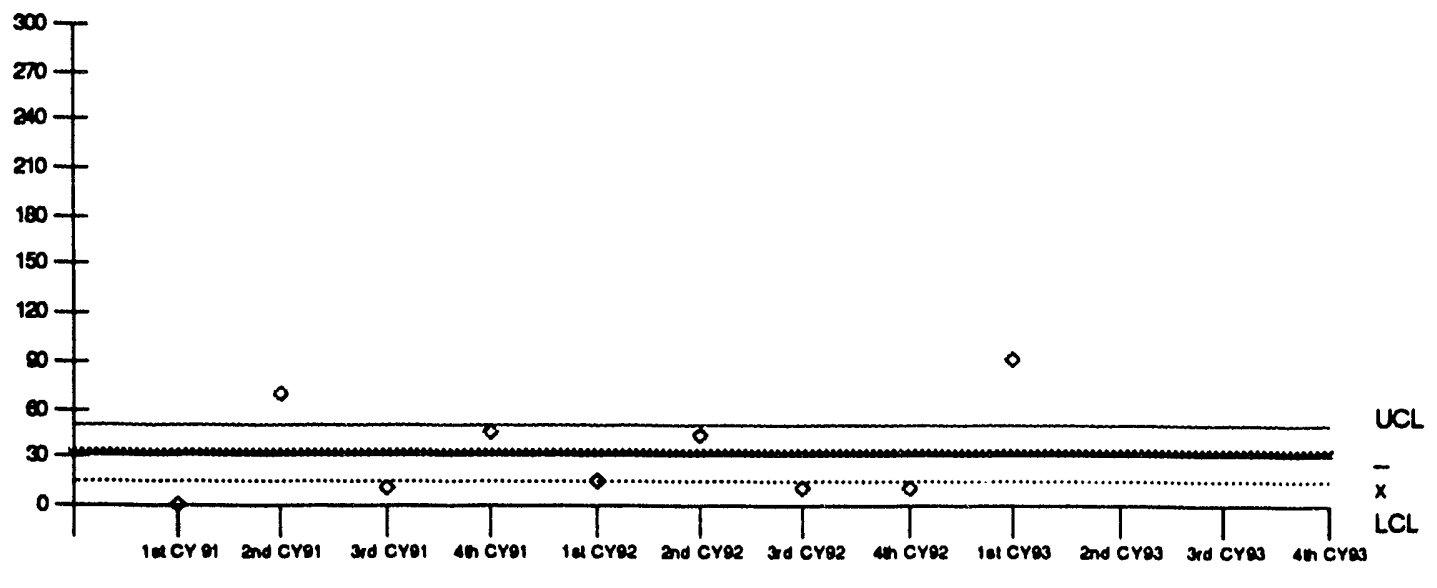

Time

This indicator was changed from the number of OSH violations identified at the facilities during the quarter to the number of OSH noncompliances open greater than 90 days for the contractor at the end of the quarter. It was not possible to backfit this indicator as the information has been kept as the number of issues identified during the current quarter rather than the number of issues open greater than 90 days. The information on the graph is of two types. The first eight data points (CY-91 and CY-92) are facility totals of issues identified during the quarter, while the final data point (first quarter of 1993) is the facility total of issues open greater than 90 days. As expected, the number of OSH violations increased from 10 identified in the fourth quarter of 1993 to 93 issues that remained open greater than 90 days at the end of the first quarter of 1993. No conclusions can be made about the ATRs performance based on the difference in the way the data points have been derived.

\subsection{Corrective Maintenance Backlog}

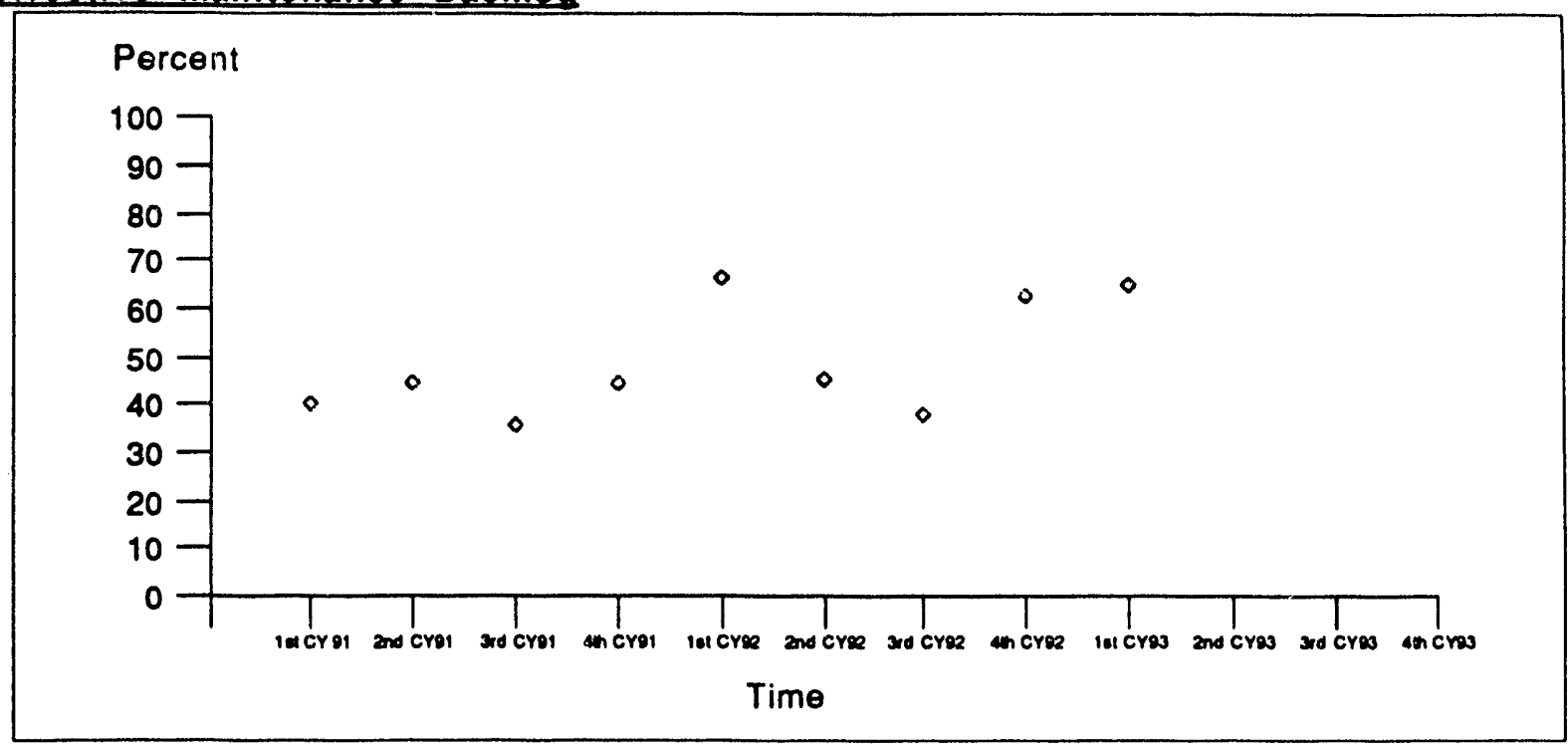

During the fourth quarter of 1992 at the ATR there were 52 CM items open greater than three months versus a total of 83 open (63\%). For the first quarter of 1993, the total number of open items increased to 204, with $133 \mathrm{CM}$ items open longer than three months $(65 \%)$. The corrective maintenance backlog increased during the first quarter of 1993 because the ATR assigned priority work towards the preparation for the Process Control Upgrade outage in the second quarter of 1993. 


\subsection{Preventive Malntenance Overdue}

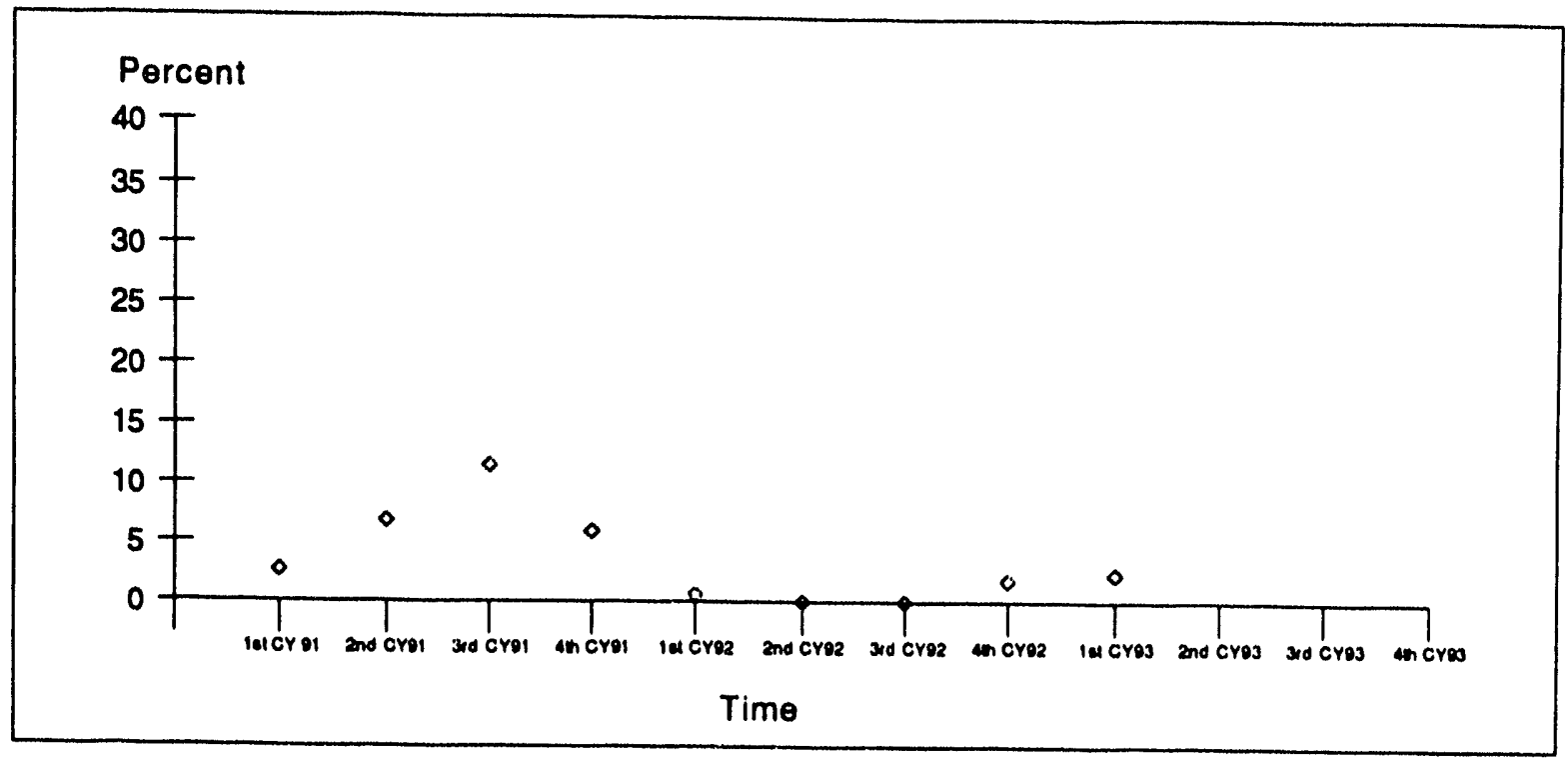

- During the fourth quarter of 1992 at the ATR, $1.8 \%$ of the scheduled PM items were not completed within the originally scheduled interval (4 of 220). For the first quarter of $1993,2.2 \%$ of the scheduled PM items were not completed within the originally scheduled interval ( 4 of 182).

\subsection{Occurrence Beports with Open Corrective Actions}

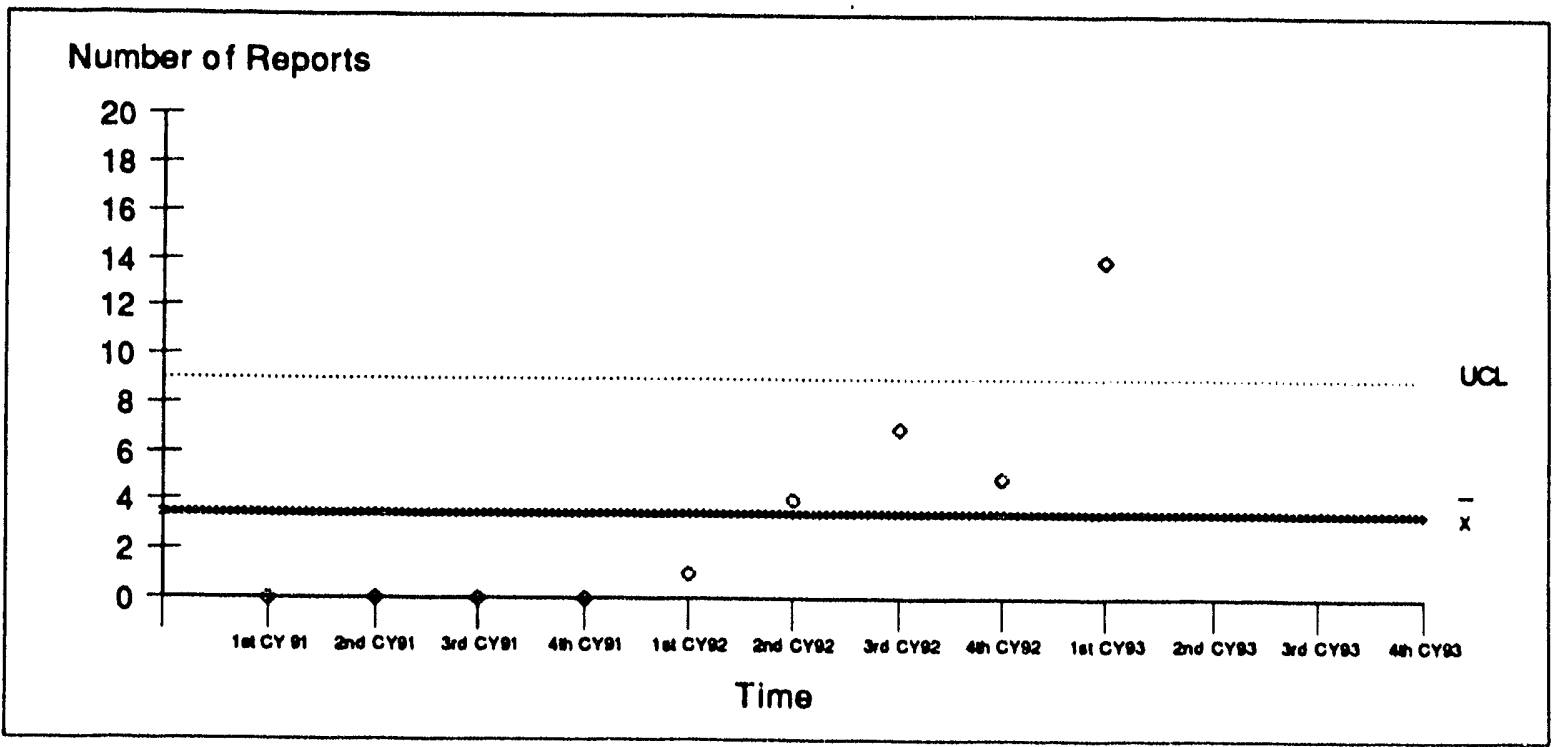

At the close of the first quarter, 14 Final Oocurrence Reports (ORs) had open corrective actions at the ATR. The increased number of occurrence reports reflects the increased emphasis on finalizing ORs. 


\section{Appendix C - Performance Indicator Charts for the RWMC Facility}

This appendix provides charts and descriptions of pertormance indicators for the RWMC facility performance. The performance indicators are identified consistent with the numbering in DOESTD-1048-92. Note that PIs 1.5, 1.6, 2.5, 4.1, and 4.2 are only reported at the contractor level and are not included in the facility appendices.

\subsection{PERSONNEL SAFETY}

\section{Collectlve Radlation Dose}

\subsubsection{Shallow Dose}

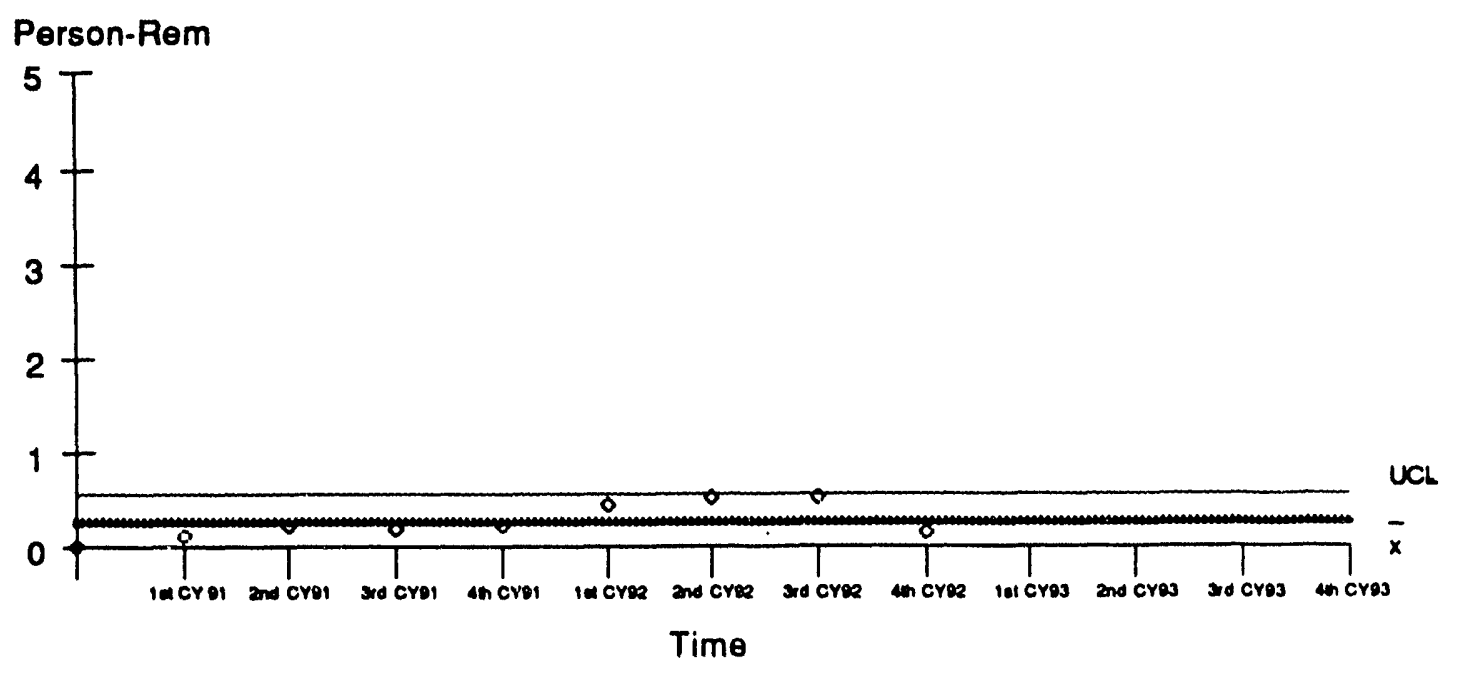

- The radiation exposures remain at levels below the ALARA goals for the year.

\subsubsection{Degp Dose}

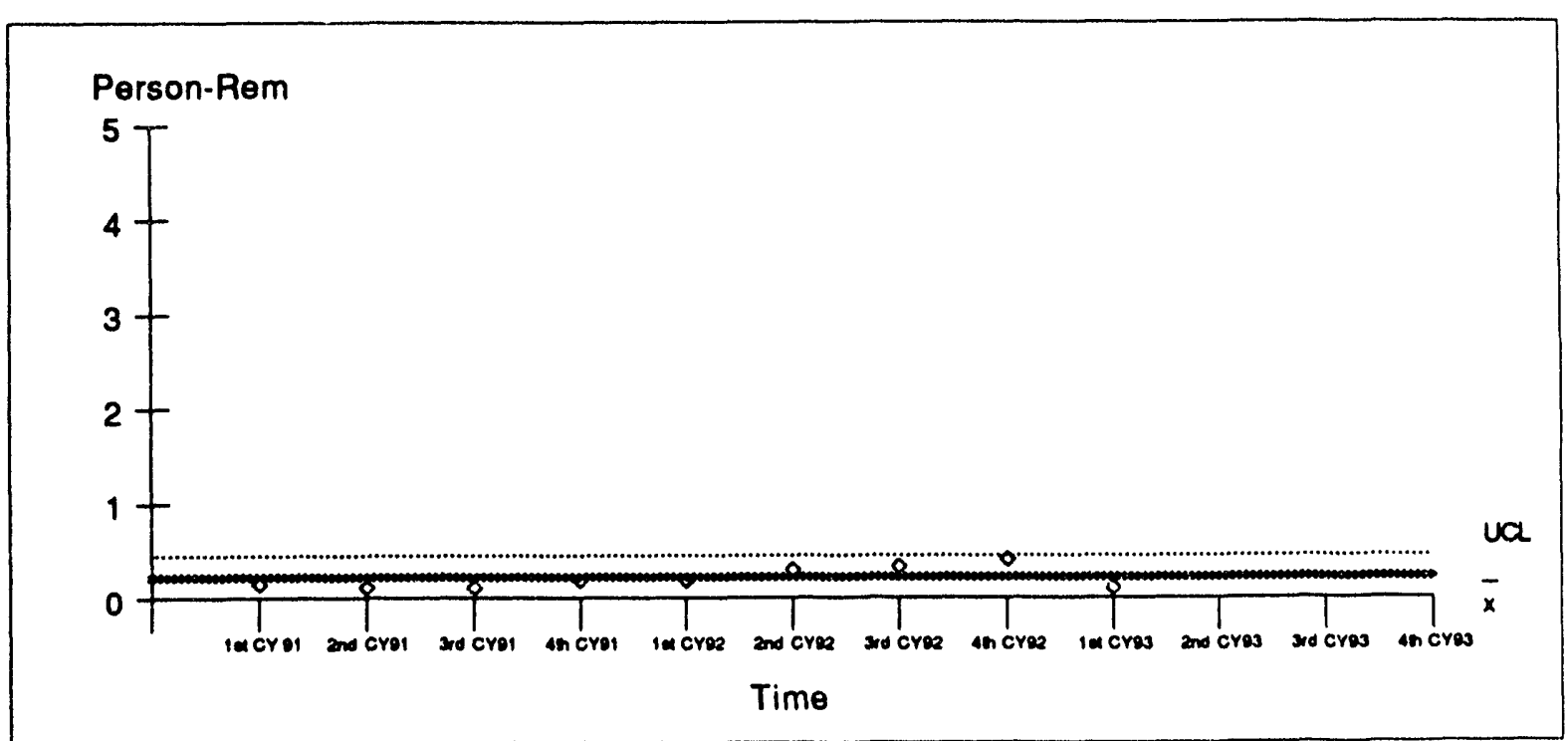

- The radiation exposures remain at levels below the ALARA goals for the year. 


\subsection{Skin/Clothing Contaminatlons}

Number of Events
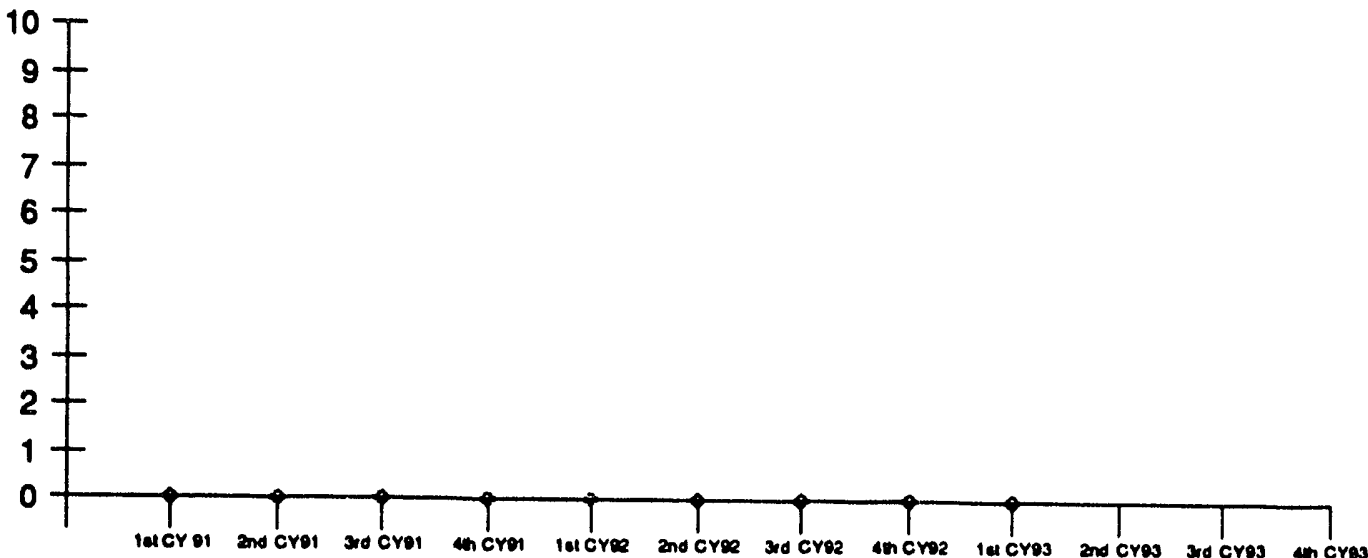

Time

- No skinclothing contamination events occurred at the RWMC during the first quartei of 1993.

\subsection{Internal Contaminations}

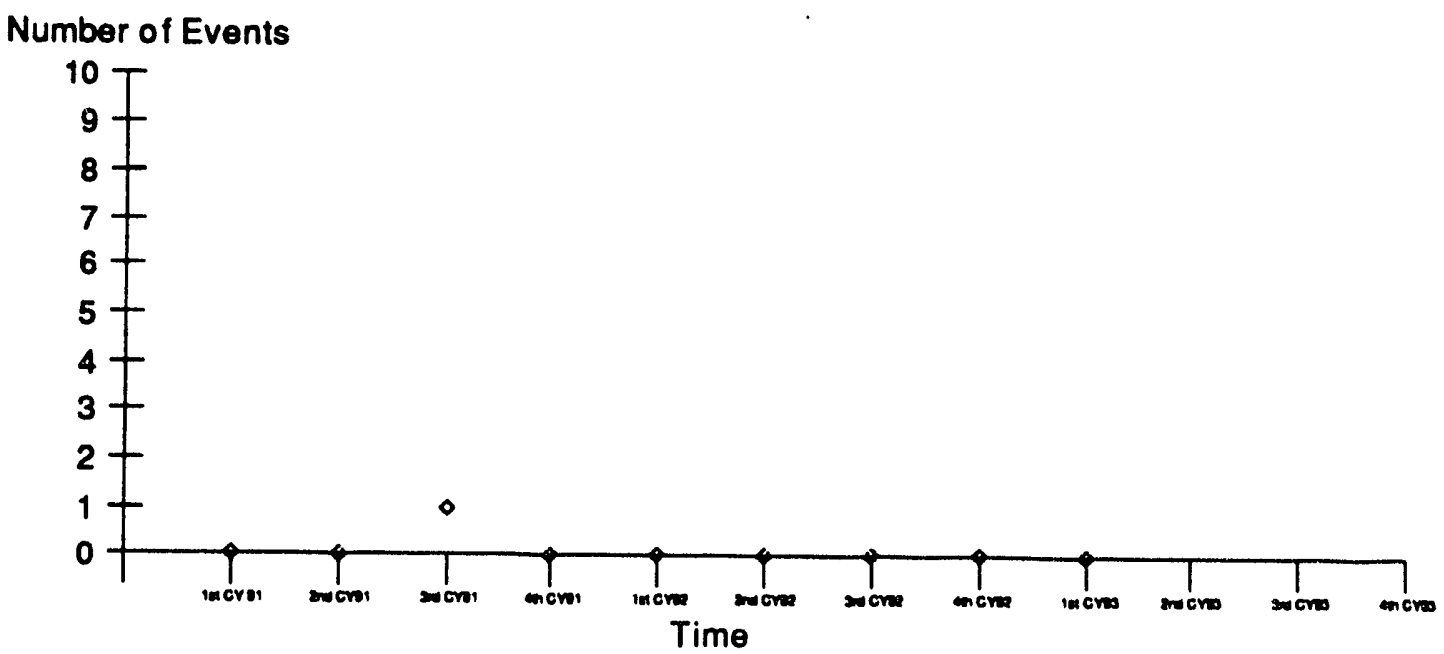

- No internal contamination events occurred at the RWMC during the first quarter of 1993. 
DOE Performance Indicators - EG\&G Idaho, Inc.

\subsection{Radloactlve or Hazardous Materlal Overexposures}

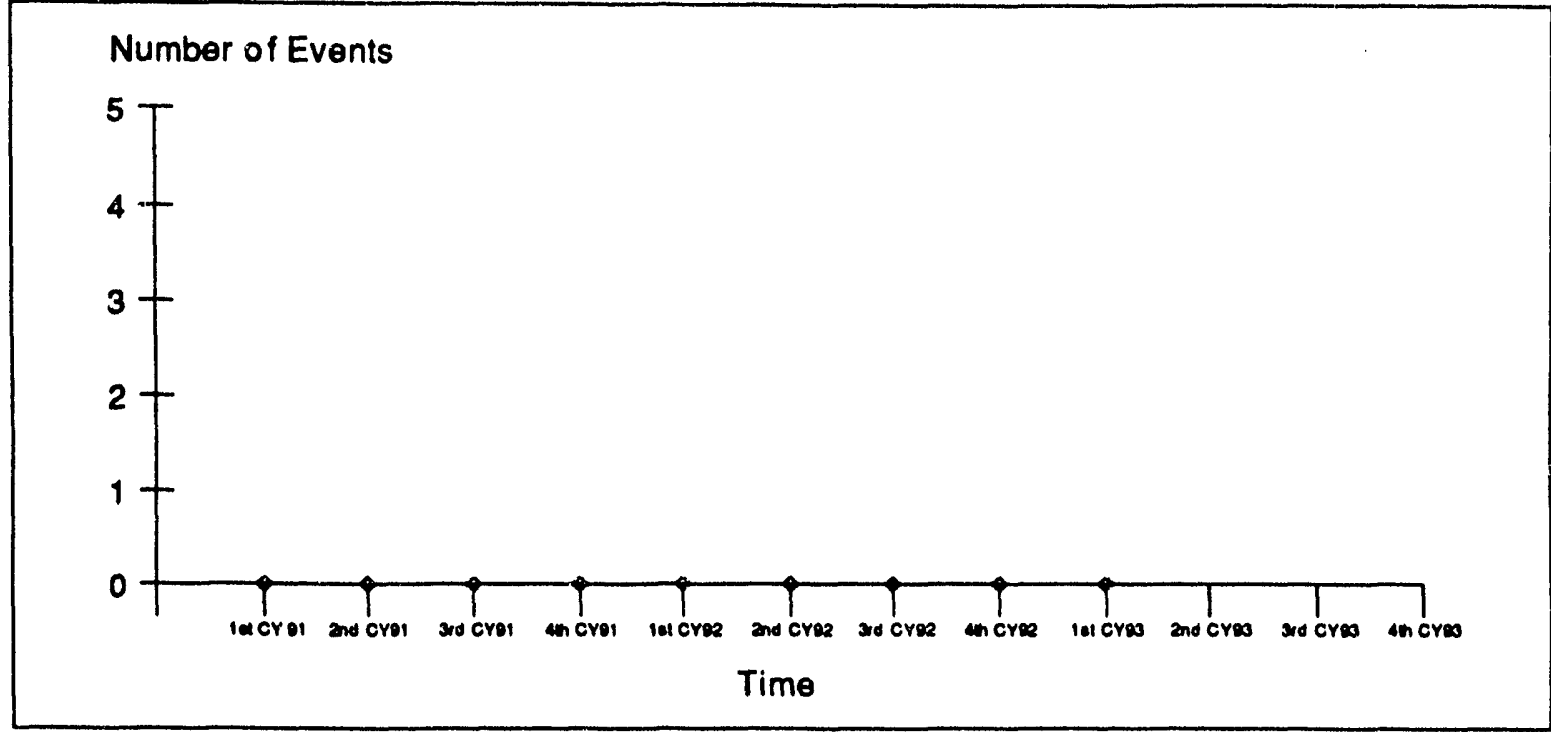

- No radioactive or hazardous material overexposures occurr6 $d$ at the RWMC during the first quarter of 1993. 
Appendix C DOE Performanc Indicators - EG\&G Idaho Inc. Performance Indlcator Charts for the RWMC Faclity 
DOE Performance Indicators - EG\&G Idaho, Inc.

\subsection{OPERATIONAL INCIDENTS}

\subsection{Unolanned Safety Functlon Actuations}

Number of Events

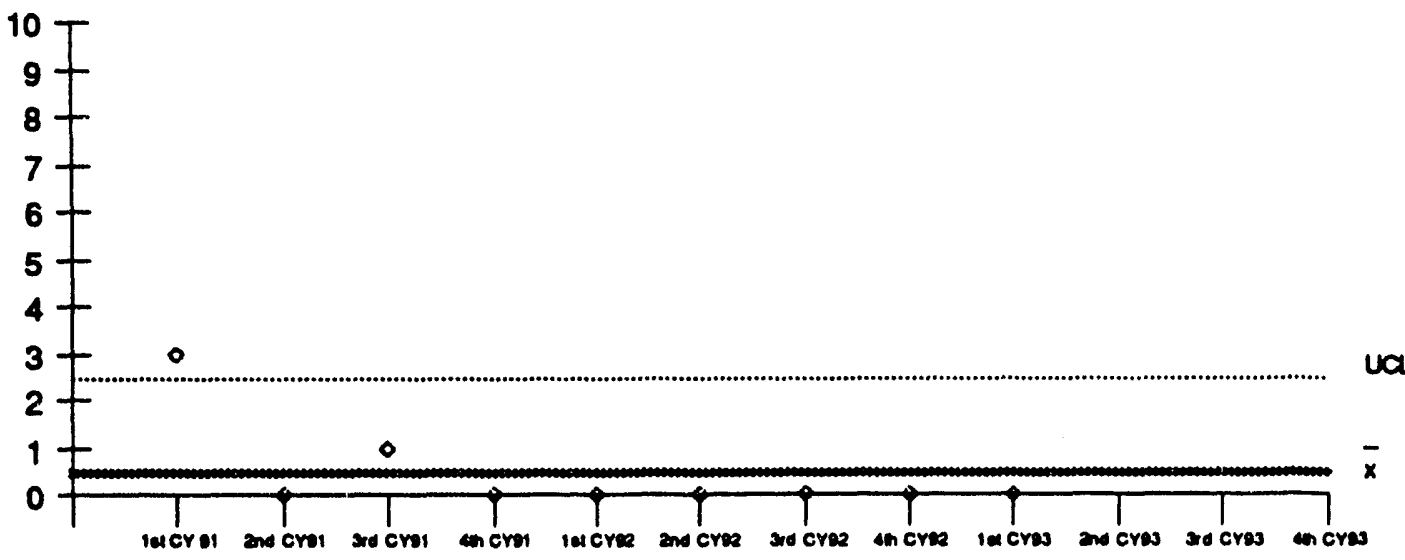

Time

- No unplanned safety function actuations occurred at the RWMC during the first quarter of 1993.

\subsection{Vlolatlons of Operating Procedures}

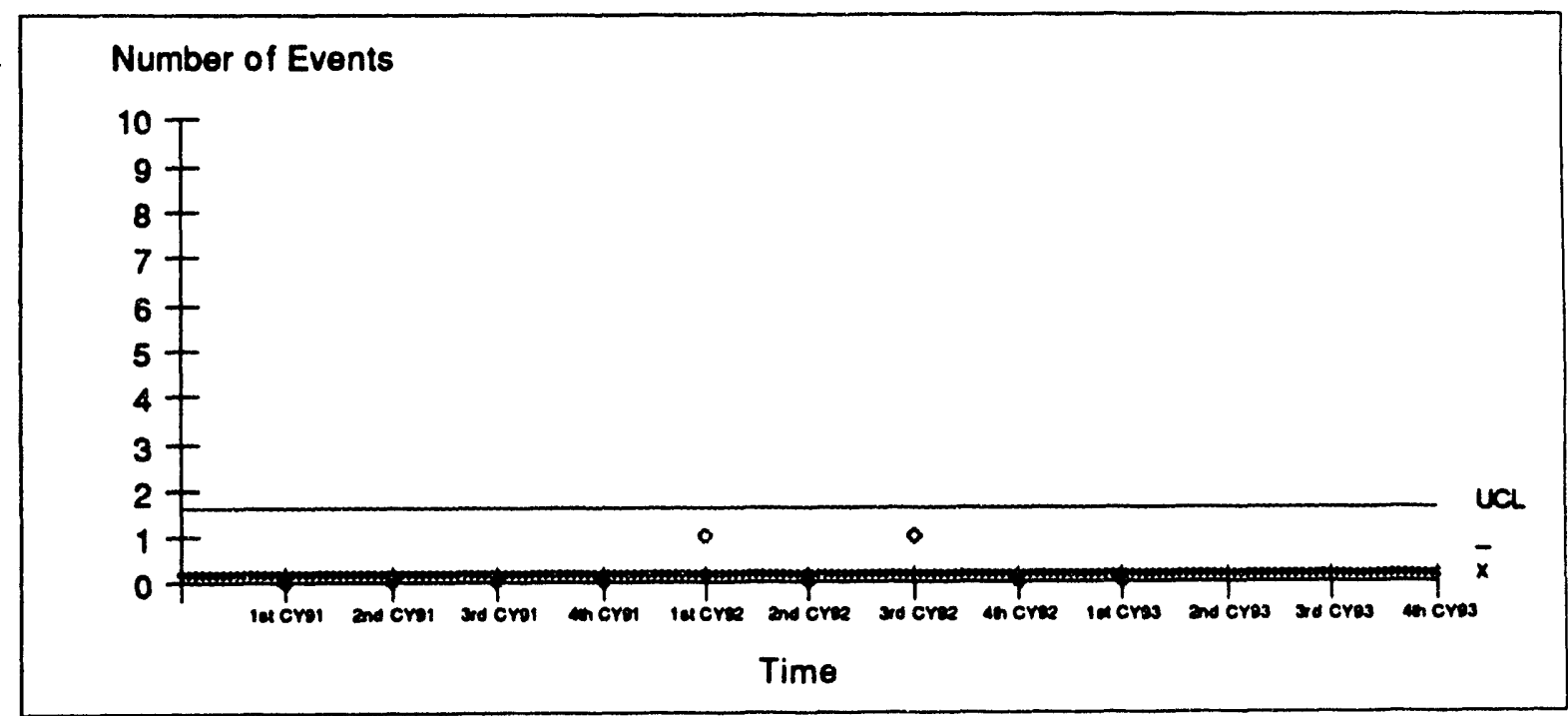

- No violations of operating procedures occurred at the RWMC during the first quarter of 1993. 


\subsection{Unplanned Shutdowns}

Number of Events

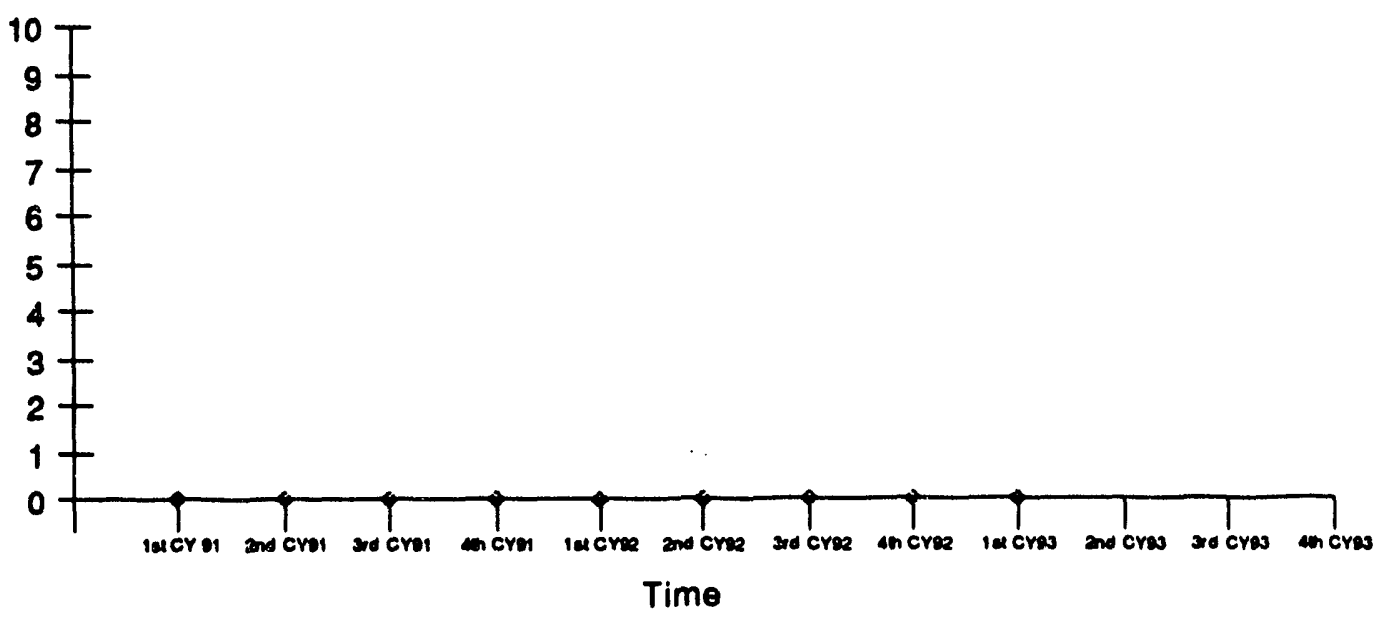

- No unplanned shutdowns occurred at the RWMC during the first quarter of 1993.

\subsection{Emergency And Unusual Occurrences}

\section{Number of Events}

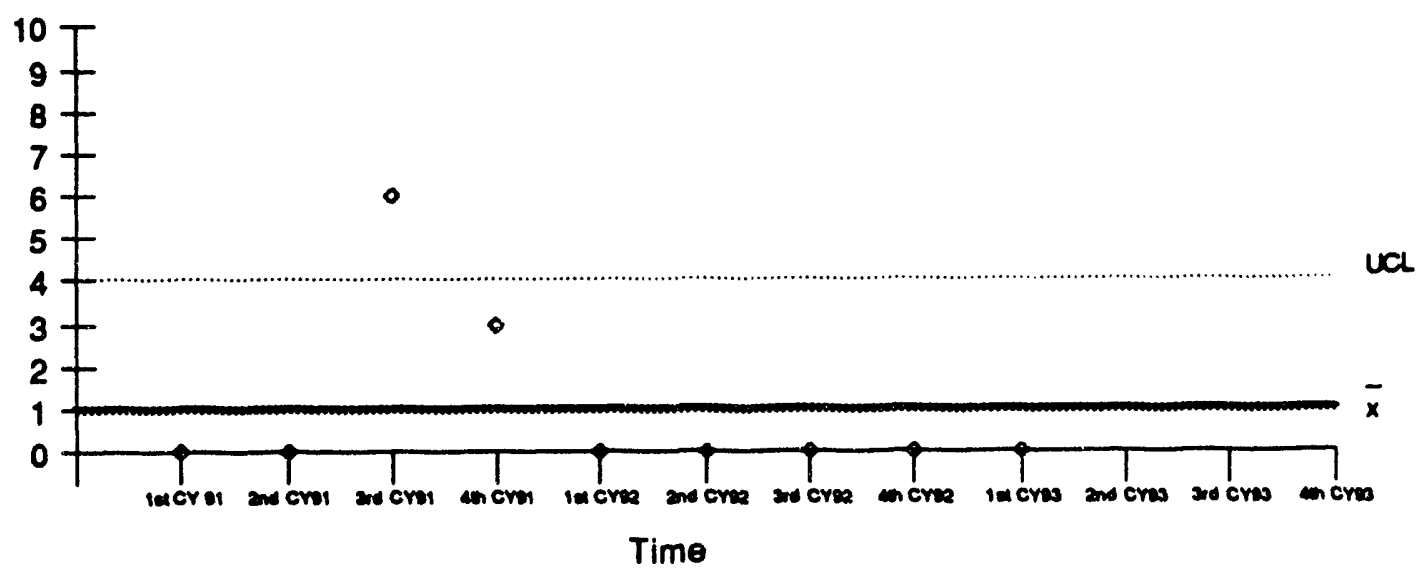

- No emergency or unusual occurrences ocsurred at the RWMC during the first quarter of 1993. 
DOE Performance Indicators - EG\&G Idaho. Inc. Appendix C

\subsection{ENVIRONMENT}

\subsection{Radionucllde Effluent}

\subsubsection{Alrborne}

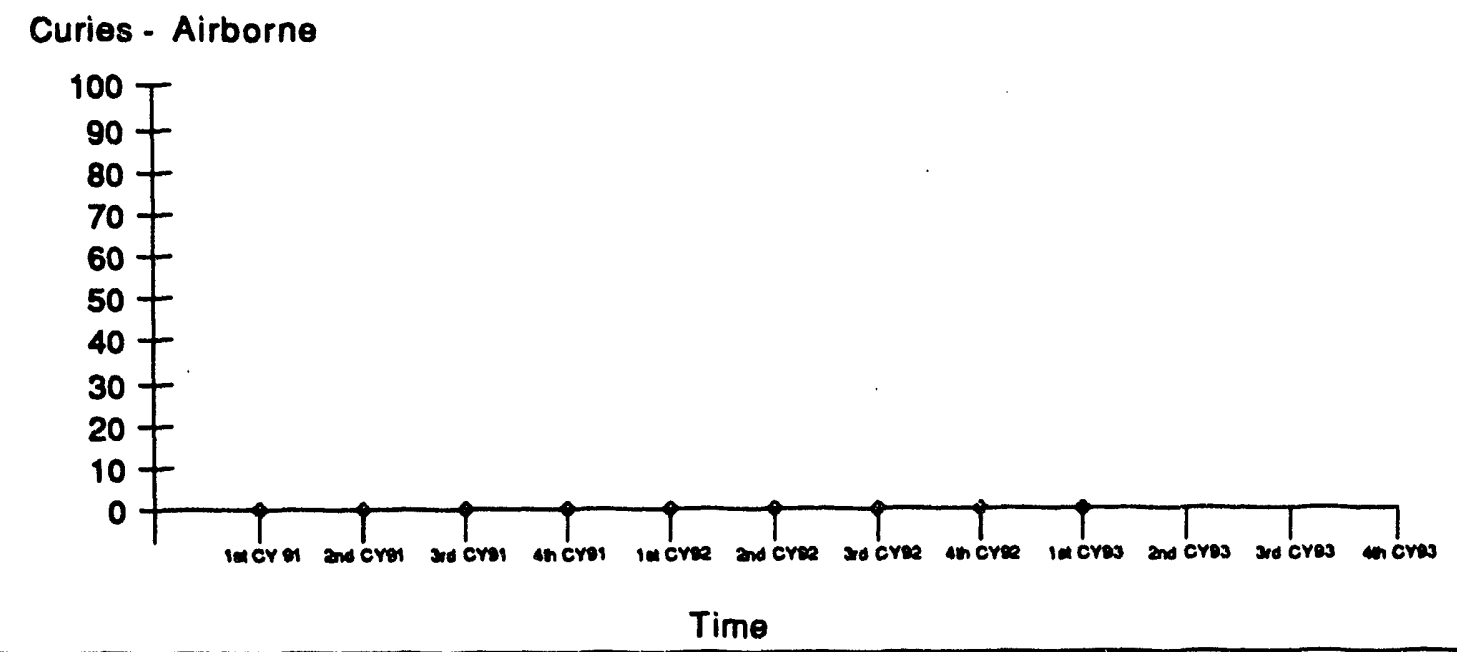

- No aiborne radionuclide effluent was released from the RWMC during the first quarter of 1993.

\subsubsection{Hould}

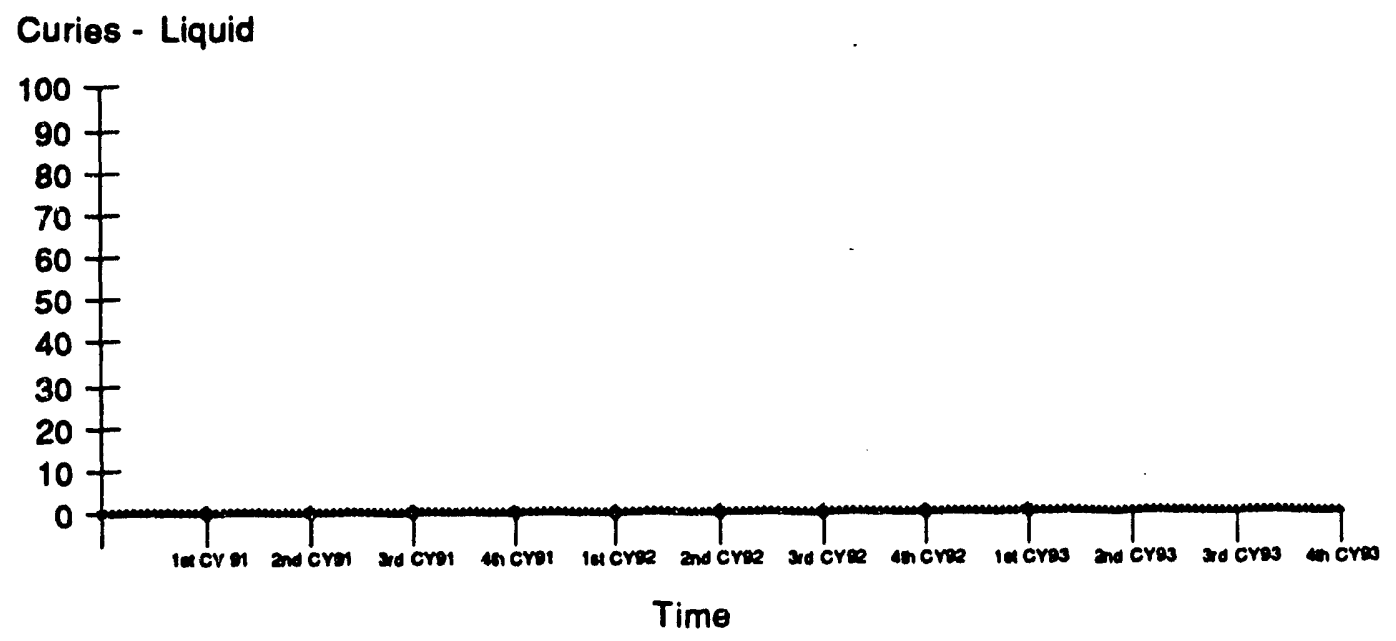

- No liquid radionuclide effluent was released from the RWMC during the first quarter of 1993. 


\subsection{Hazardous Substance/Requlated Pollutant Effluent}

\subsubsection{Airborne}

\section{Pounds - Airborne}

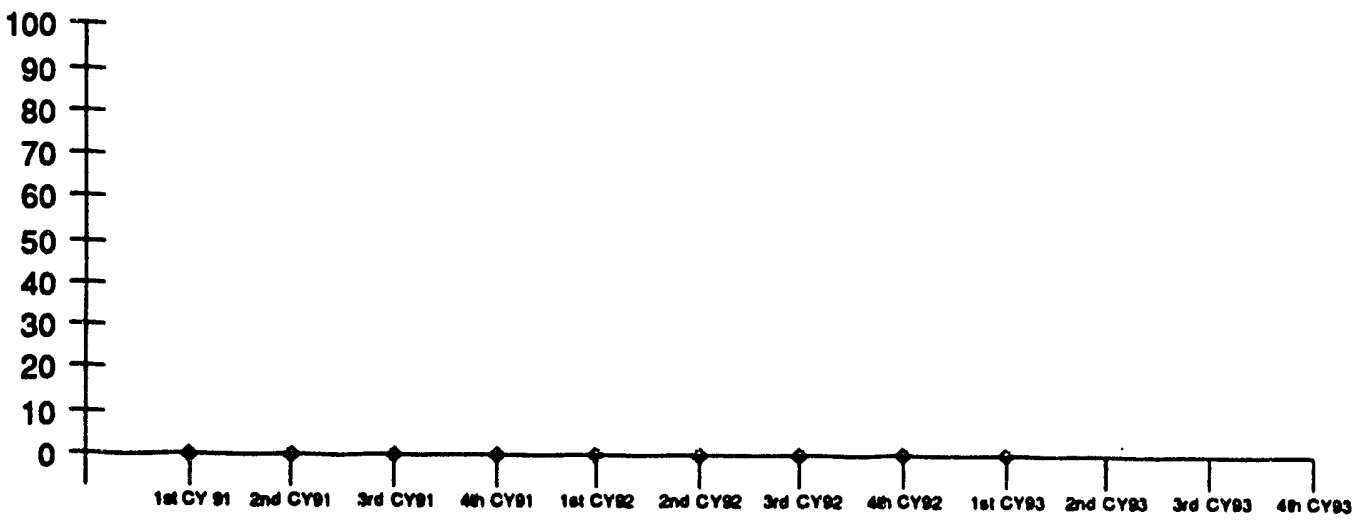

Time

No airborne hazardous substances or regulated pollutants were released by the RWMC during the first quarter of 1993.

\subsubsection{Liauld}

Liquid - Gallons

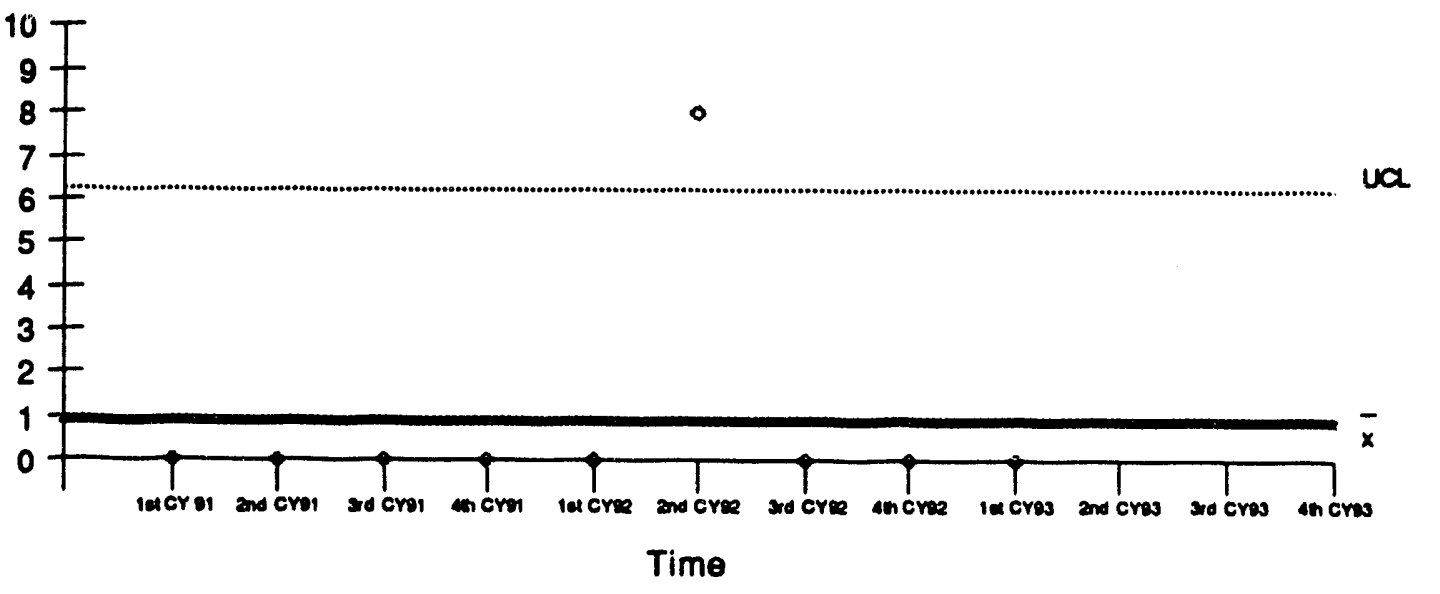

No liquid hazardous substances or regulated pollutants were released by the RWMC during the first quarter of 1993. 


\subsection{EnvilonmentaL_Incidents}

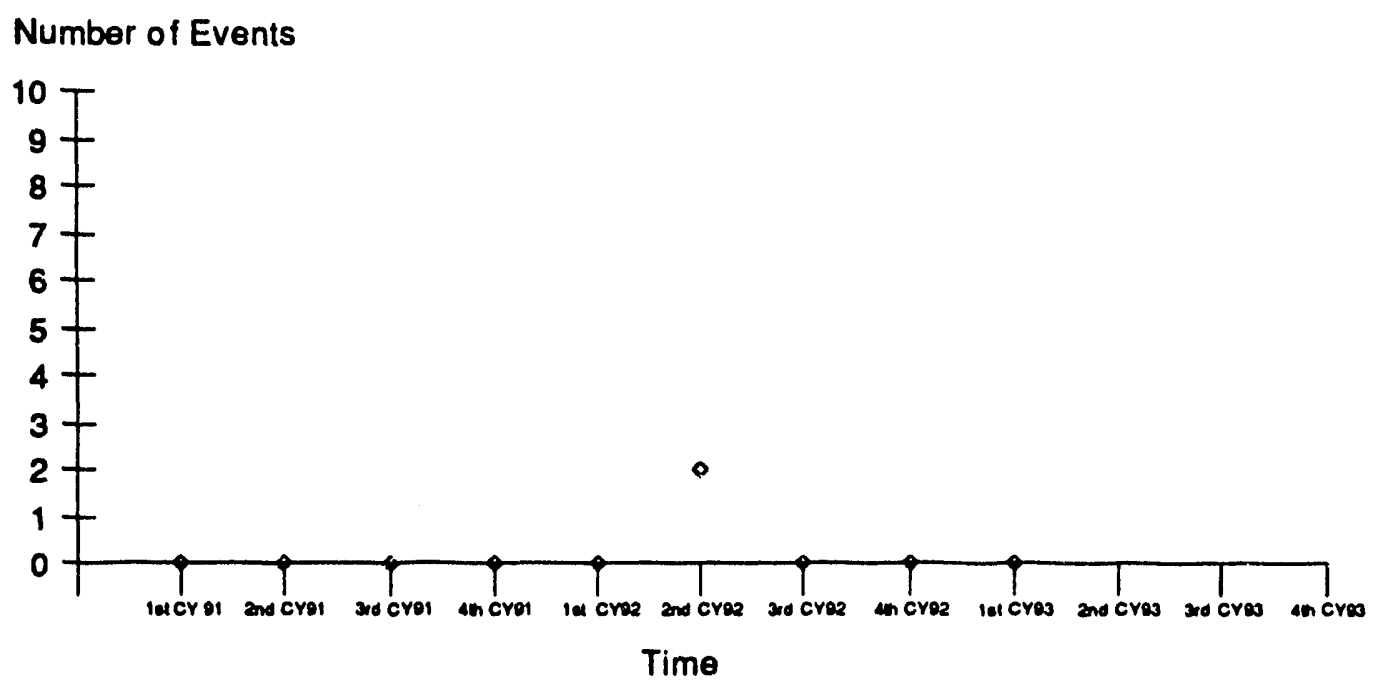

- No environmental incidents occurred at the RWMC during the first quarter of 1993.

\subsection{Solld Low Level Waste Generated}

\subsubsection{Radloactlve Waste}

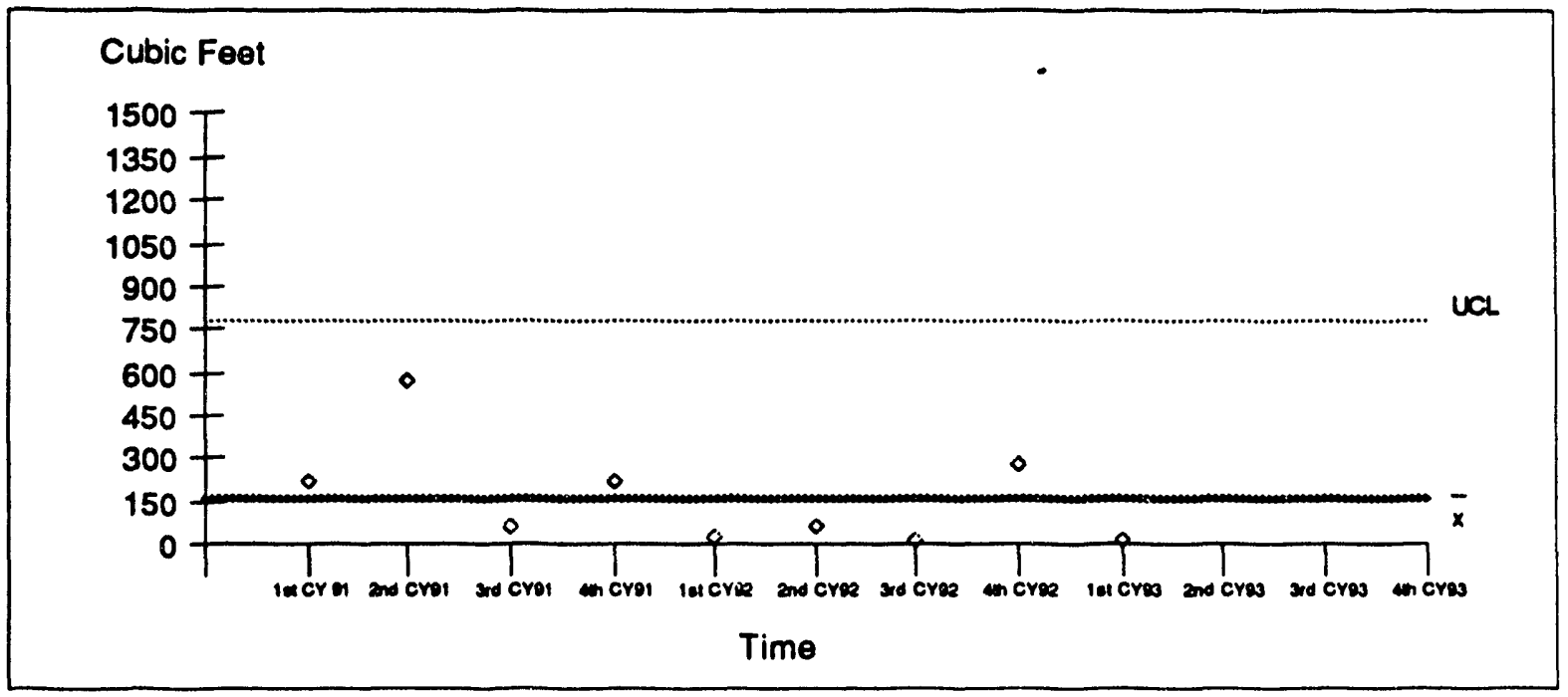

- The low level radioactive waste generated at the RWMC in the first quarter of CY 1993 was waste generated during routine operations. 


\subsubsection{Hazardous Waste}

\section{Cubic Feet}

10
9
8
7
6
5
4
3
2
1
0

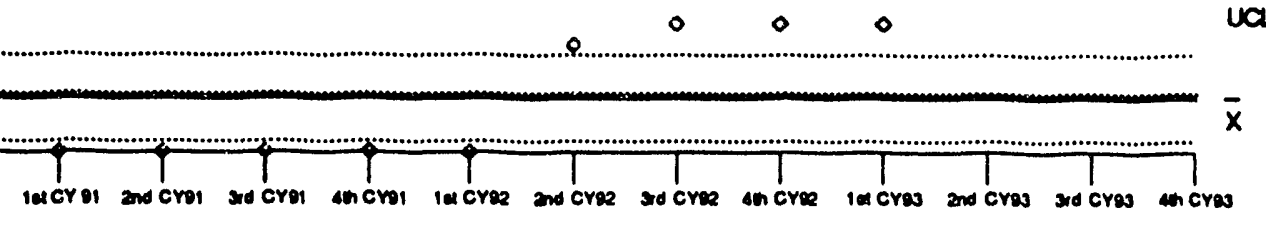

Time

The low level hazardous waste that was generated at the RWMC in the first quarter of CY 1993 was three industrial lead acid batteries that were returned for recycling.

\subsubsection{Mlxed Waste}

\section{Cubic Feet}

100
90
80
70
60
50
40
30
20
10
0

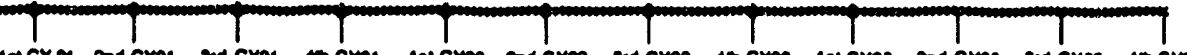

Time

No low level mixed waste was generated by the RWMC in the first quarter of CY 1993. 


\subsection{MANAGEMENT}

\subsection{OSH Noncompllance}

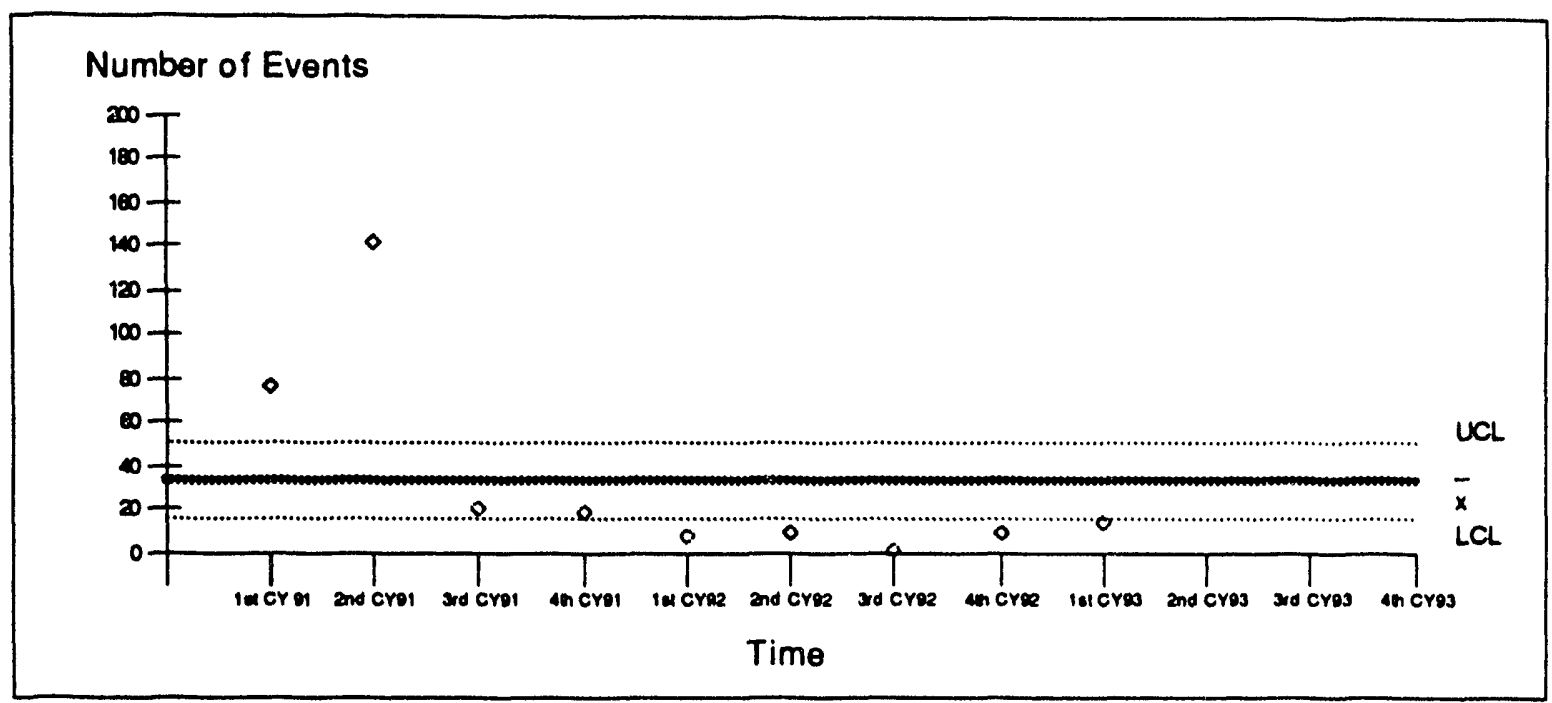

This indicator was changed from the number of OSH violations identified at the facilities during the quarter to the number of OSH noncompliances open greater than 90 days for the contractor at the end of the quarter. It was not possible to backfit this indicator as the information has been kept as the number of issues identified during the current quarter rather than the number of issues open greater than 90 days. The information on the graph is of two types. The first eight data points (CY-91 and CY-92) are facility totals of issues identified during the quarter, while the final data point (first quarter of 1993) is the facility total of issues open greater than 90 days. As expected, the number of OSH violations increased from 10 identified in the fourth quarter of 1993 to 15 issues that remained open greater than 90 days at the end of the first quarter of 1993. No conclusions can be made about the RWMCs performance based on the difference in the way the data points have been derived. All of the open items are ranked as low priority.

\subsection{Corrective Maintenance Backlog}

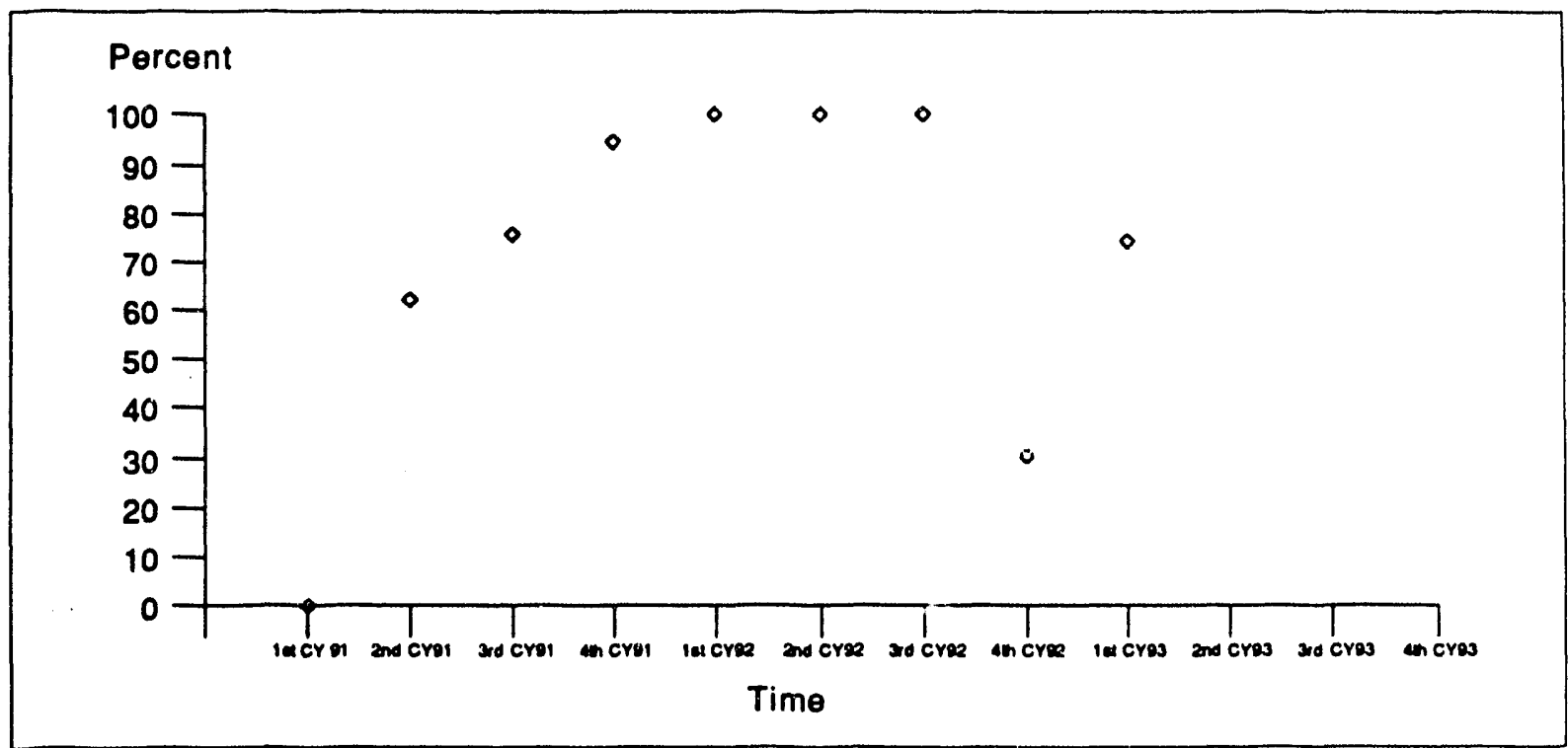

During the fourth quarter of 1992 at the RWMC there were 52 CM items open greater than three months versus a total of 170 open (31\%). For the first quarter of 1993, the total number of open items decreased to 81 , with $60 \mathrm{CM}$ items open longer than three months (74\%). 

Performance Indlcator Charts for the RWMC Facilly

\subsection{Preventlve Maintenance Overdue}

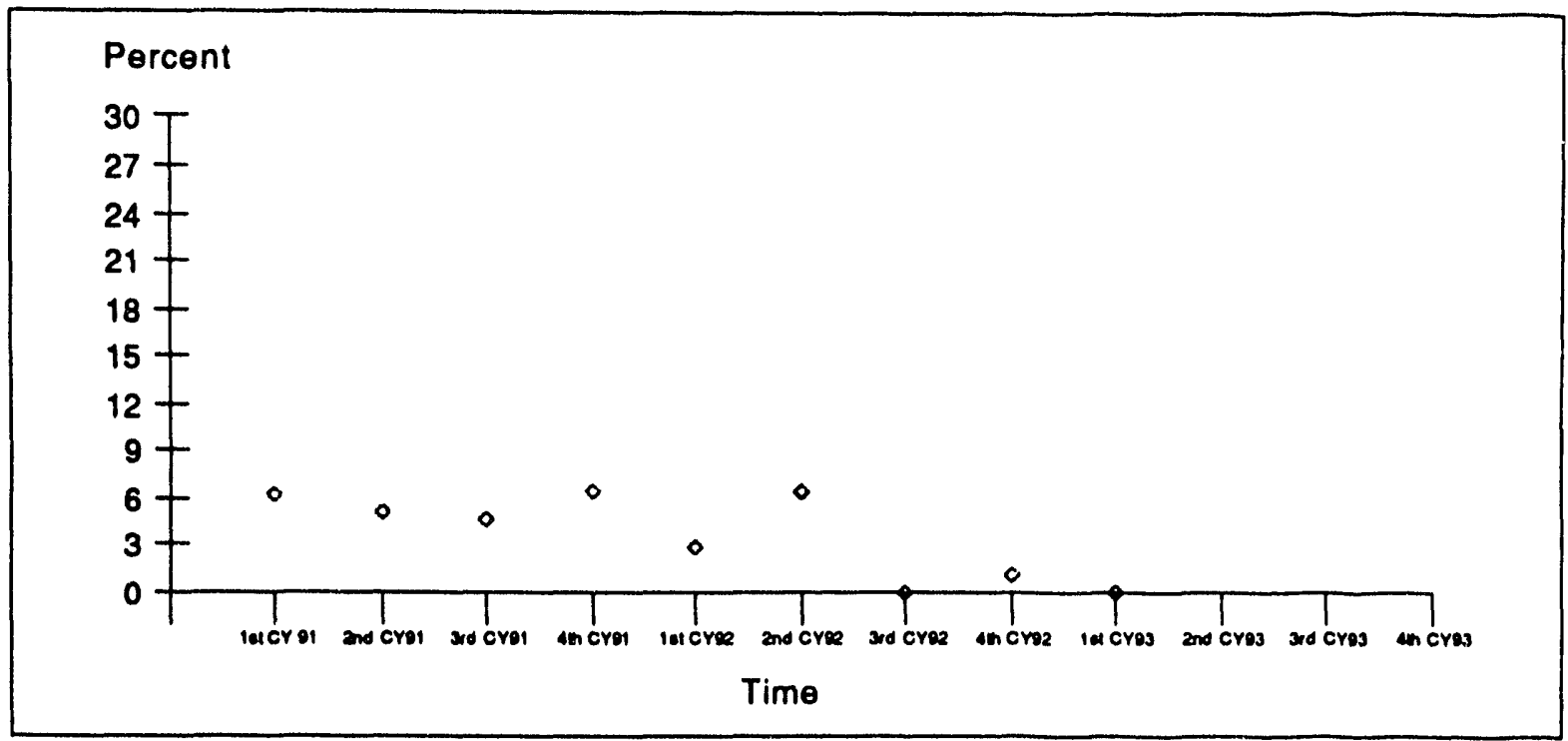

During the fourth quarter of 1992 at the RWinC, $1.2 \%$ of the scheduled PM items were not completed within the originally scheduled interval ( 3 of 248). For the first quarter of 1993, none of the scheduled PM items were not completed within the originally scheduled interval ( 0 of 265).

\subsection{Occurrence Reports With Open Corrective Actions}

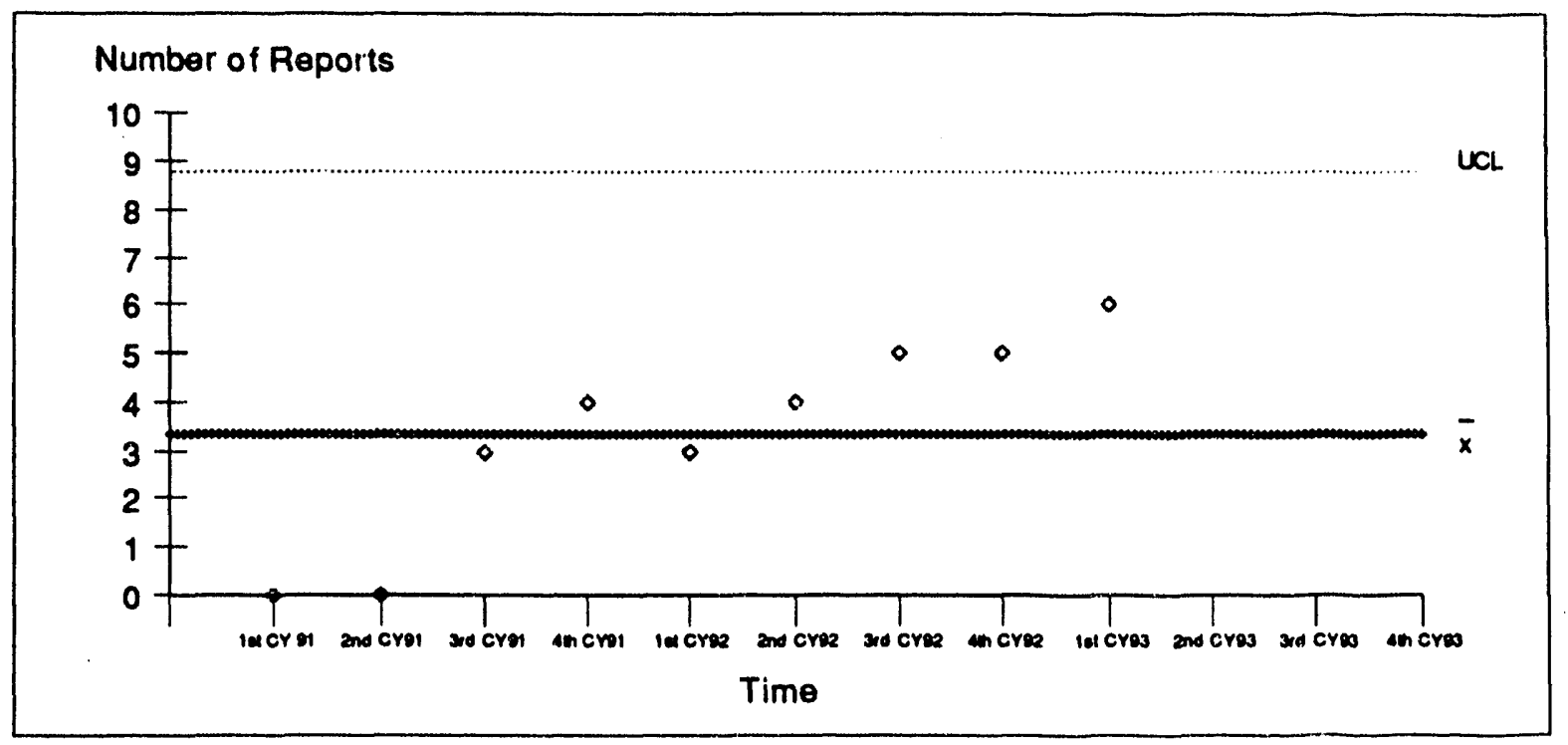

At the close of the first quarter, 6 Final Occurrence Reports (ORs) had open corrective actions at the RWMC. The increased number of occurrence reports reflects the increased emphasis on finalizing ORs. 


\section{Appendix D - Performance Indicator Charts for the WERF Facility}

This appendix provides charts and descriptions of performance indicators for the WERF facility performance. The performance indicators are identified consistent with the numbering in DOESTD-1048-92. Note that PIs $1.5,1.6,2.5,4.1$, and 4.2 are only reported at the contractor level and are not included in the facility appendices.

\subsection{PERSONNEL SAFETY}

\subsection{Collectlve Radiation Dose}

\subsubsection{Shallow Dose}

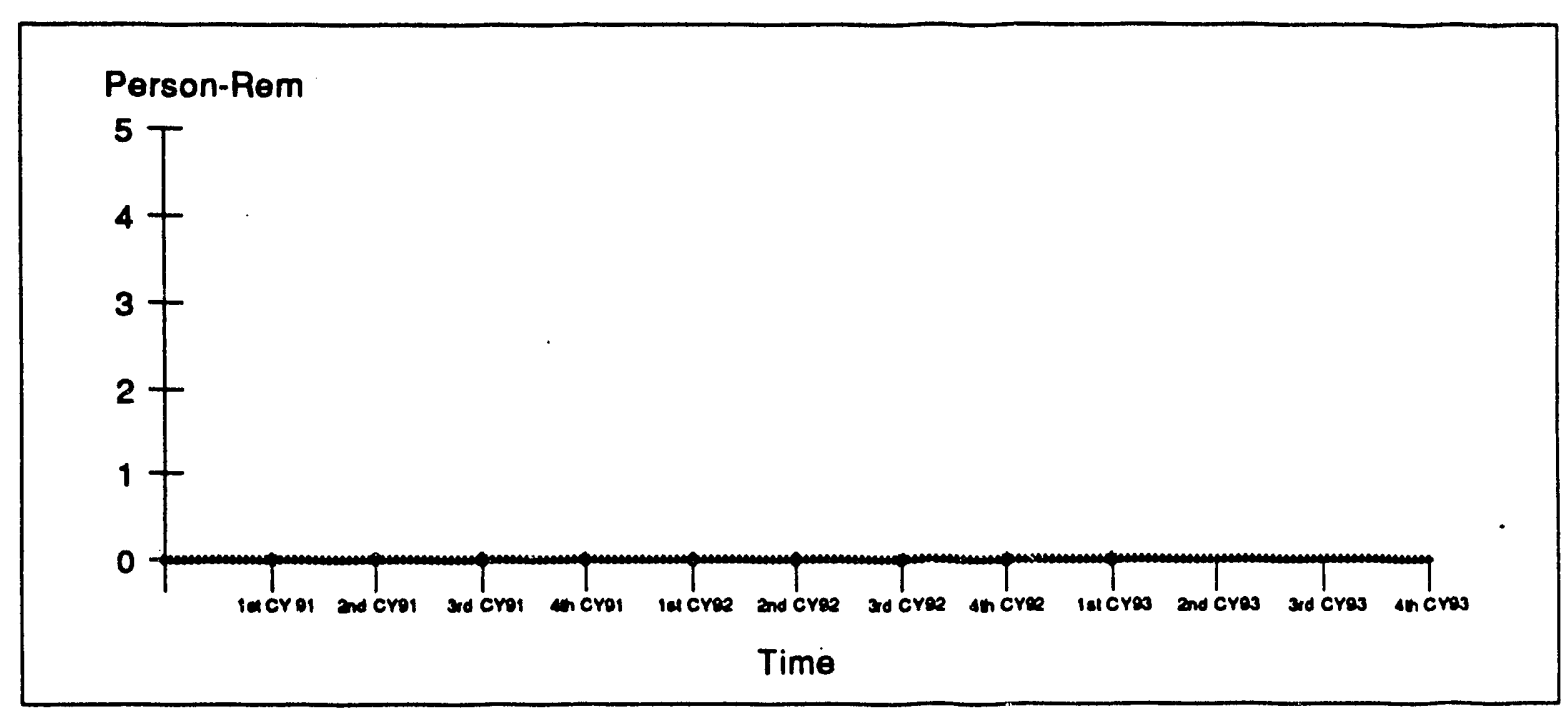

The radiation exposures remain at levels below the ALARA goals for the year.

\subsubsection{Deep Dose}

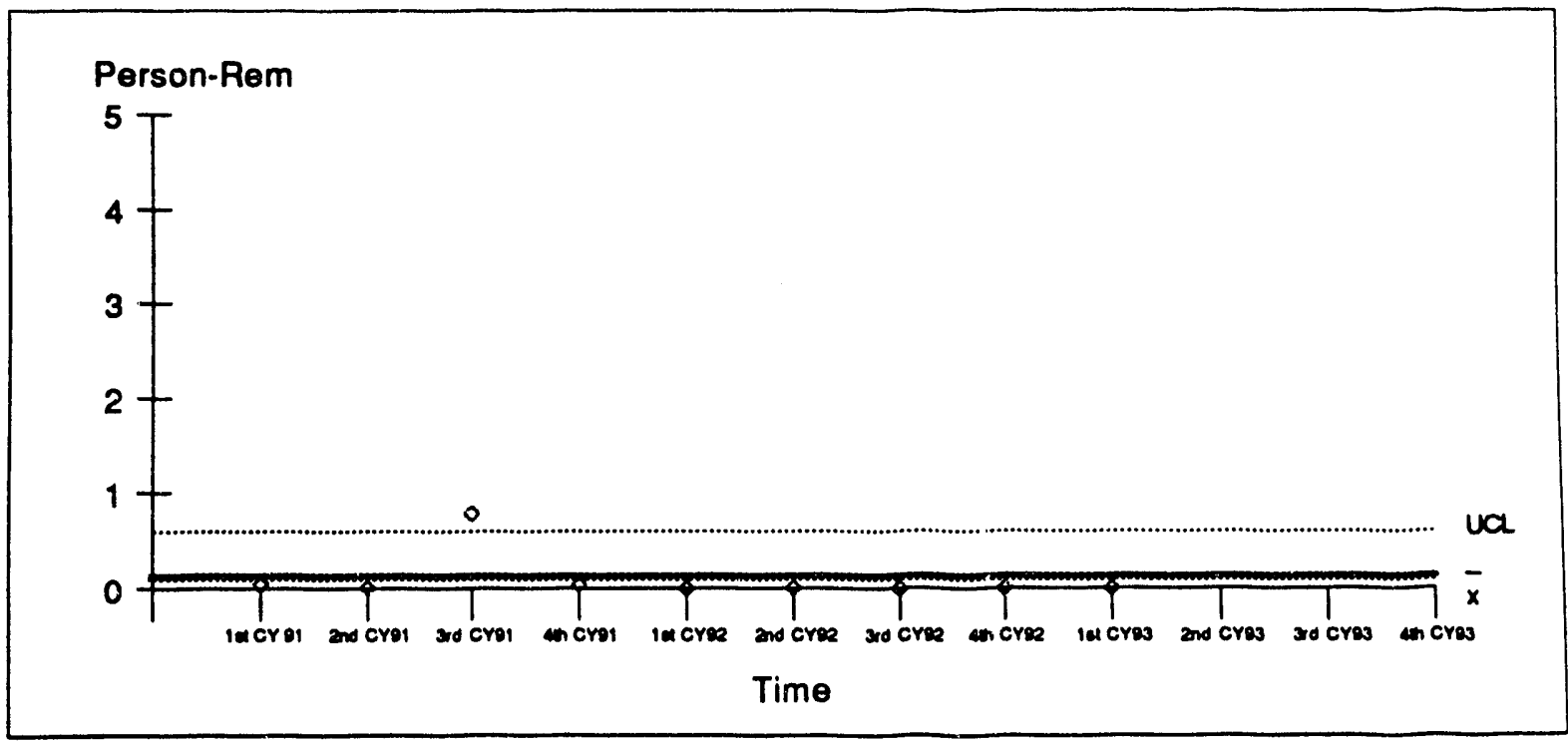

- The radiation exposures remain at levels below the ALARA goals for the year. 
Appendix D DOE Performance Indicators - EG\&G Idaho. Inc. Performance Indicator Charts for the WERF Facility

\subsection{Skln/Clothing Contaminations}

\section{Number of Events}

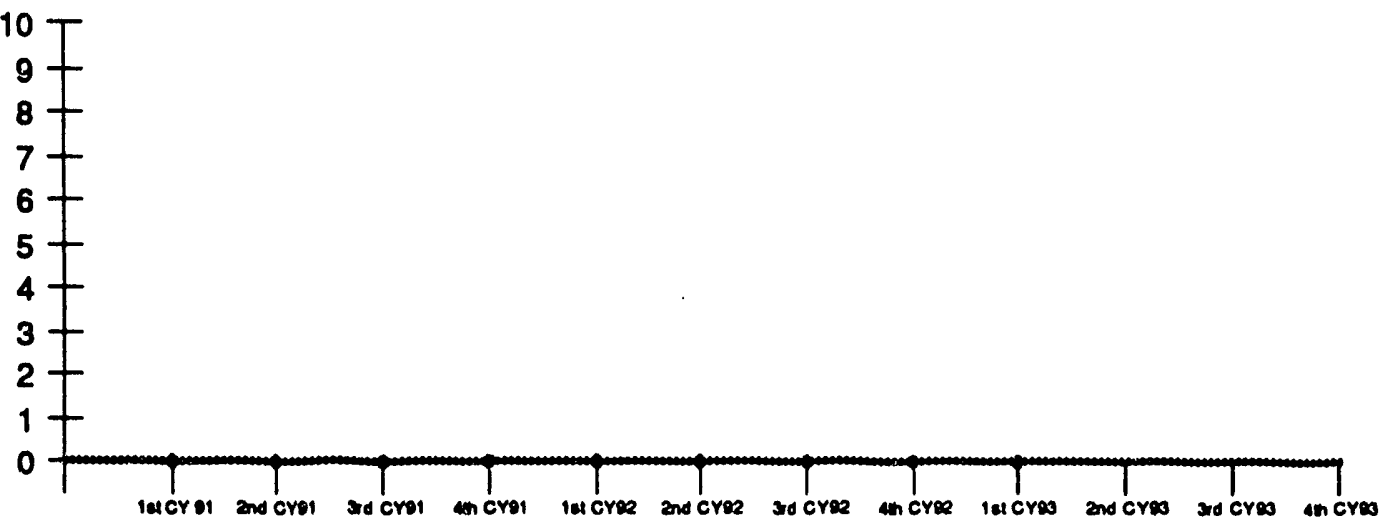

Time

- No skin/clothing contamination events occurred at the WERF during the first quarter of 1993.

\section{1,3 Internal Contaminations}

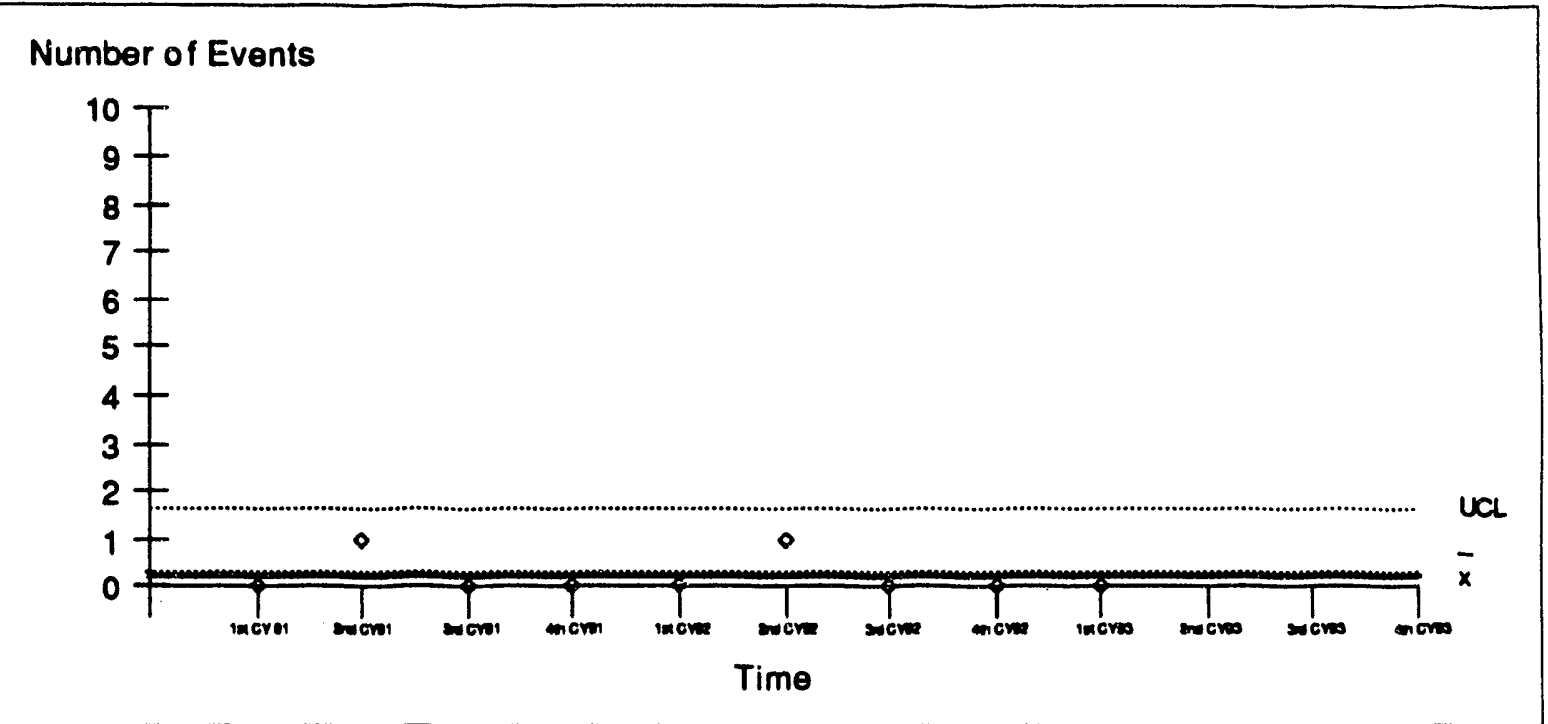

- No internal contamination events occurred at the WERF during the first quarter of 1993. 
DOE Performance Indicators - EG\&G Idaho, Inc.

\subsection{Radloactive or Hazardous Materlal Overexposures}

Number of Events

10
9
8
7
7
6
5
4
3
2
1
1
0

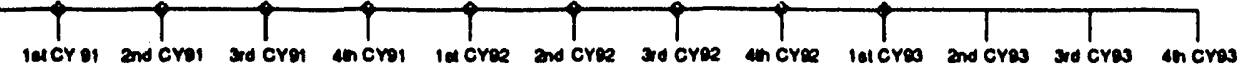

Time

- No radioactive or hazardous material overexposures occurred at the WERF during the first quarter of 1993. 
Appendix D

DOE Performance Indicators - EG\&G Idaho, Inc.

Performance Indicator Charts for the WERF Facility 


\subsection{OPERATIONAL INCIDENTS}

\subsection{Unplanned Safety Function Actuations}

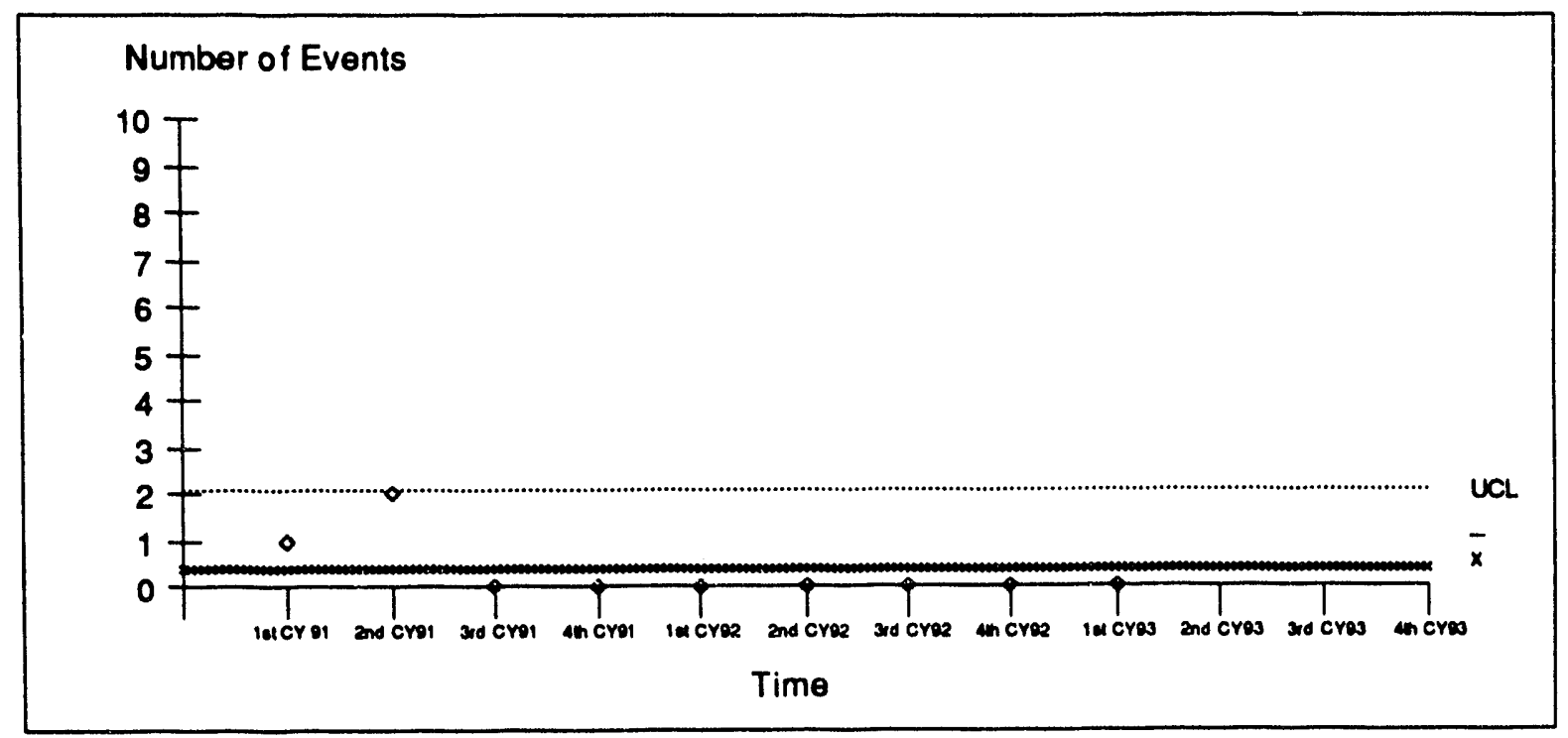

- No unplanned safety function actuations occurred at the WERF during the first quarter of 1993.

\subsection{Violations of Operating Procedures}

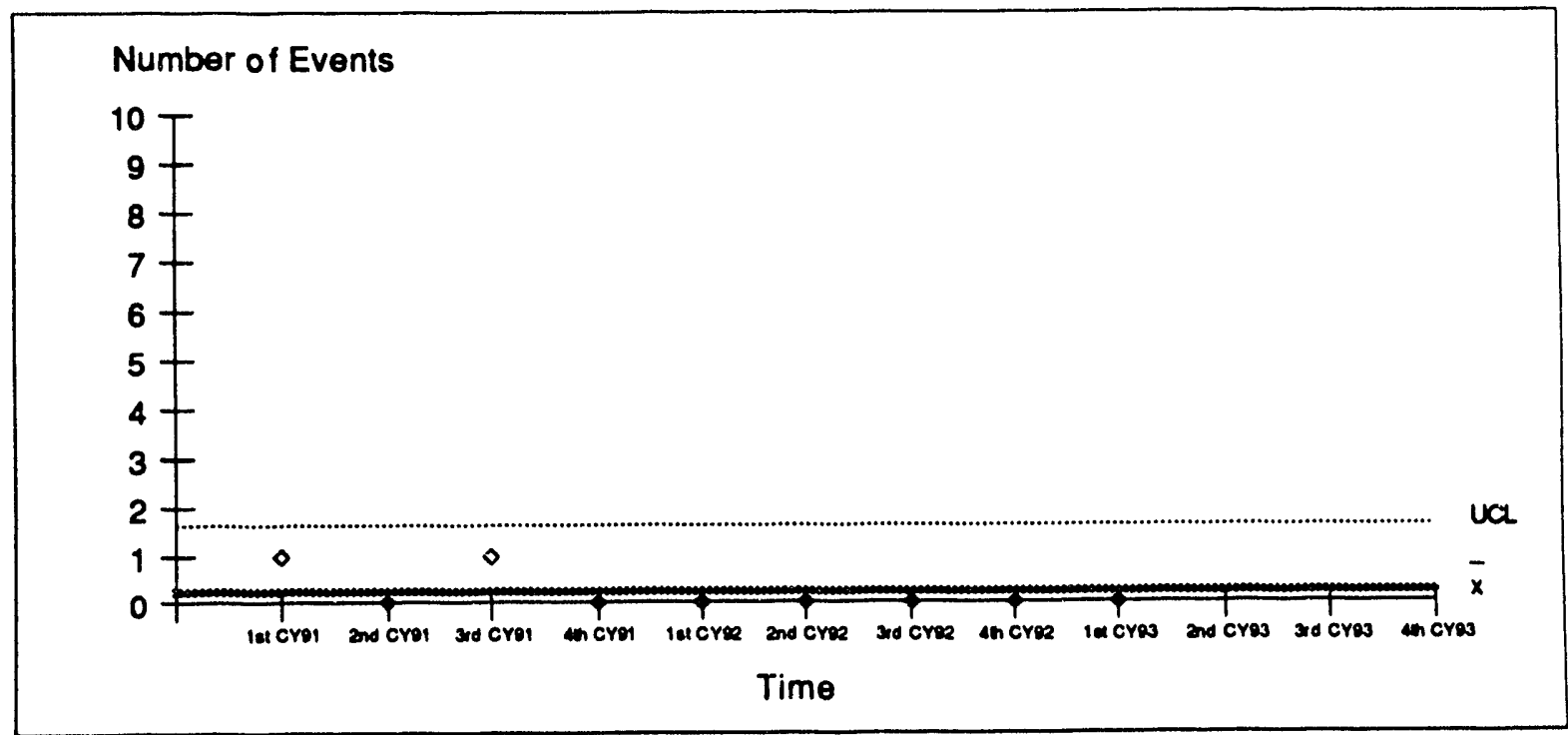

- No violations of operating procedures occurred at the WERF during the first quarter of 1993. 


\subsection{Unplanned Shutdowns}

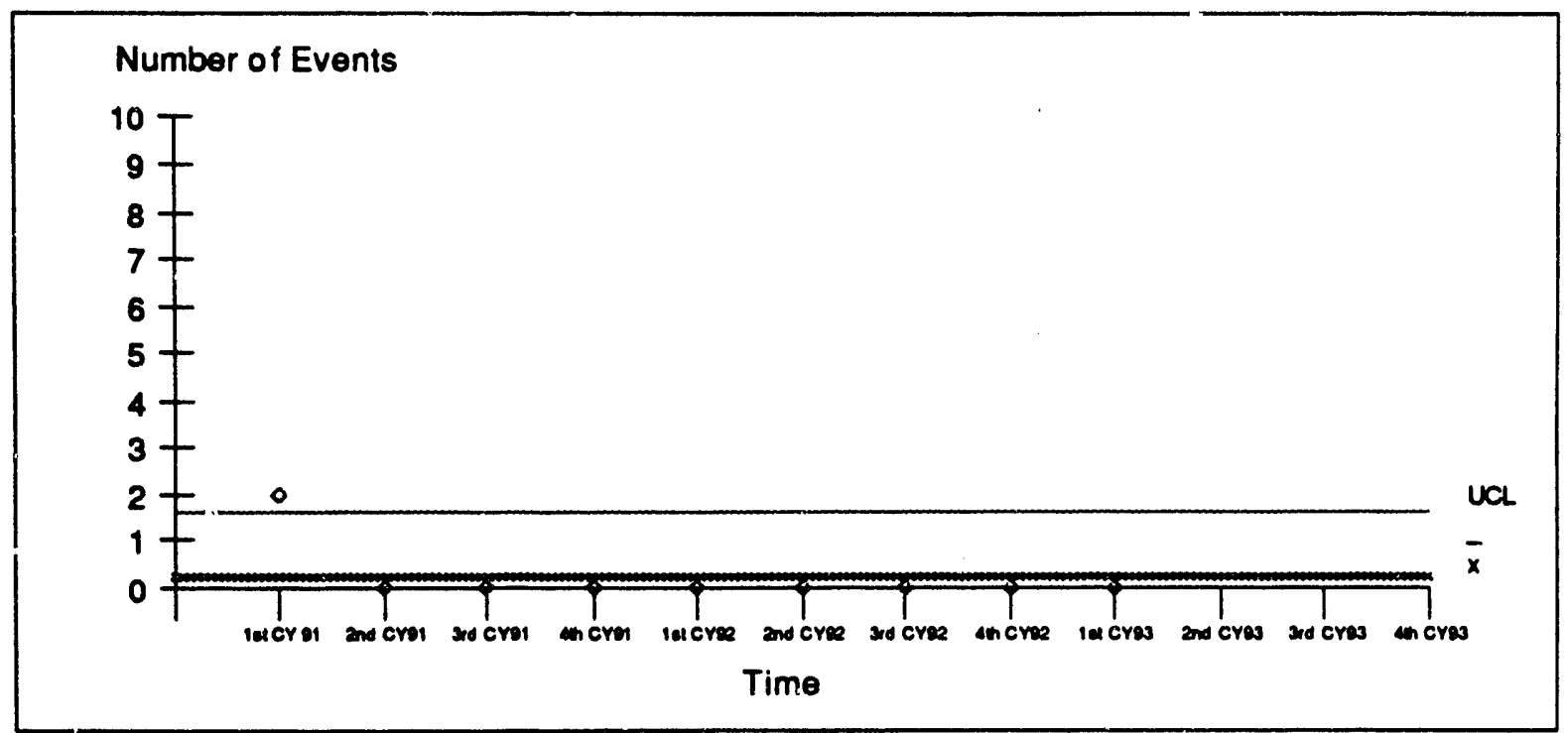

- No unplanned shutdowns occurred at the WERF during the first quarier of 1993.

\subsection{Emergency And Unusual Occurrences}

\section{Number of Events}

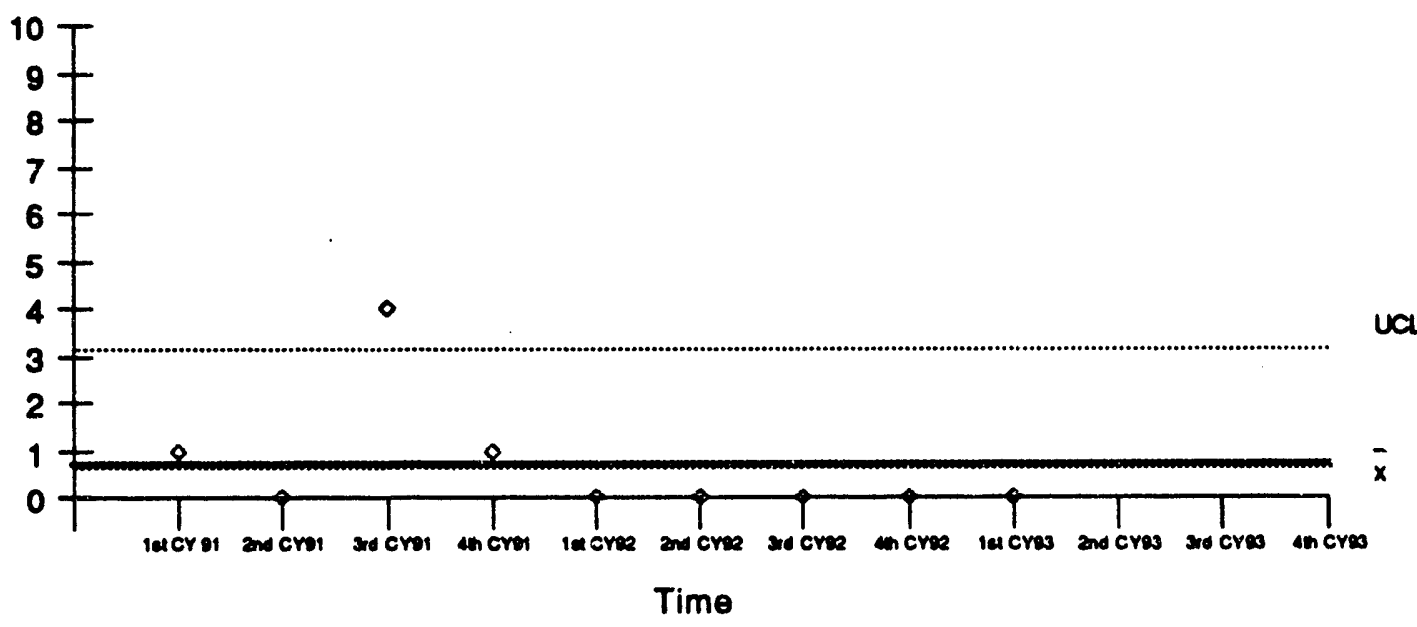

- No emergency or unusual occurrences occurred at the WERF during the first quarter of 1993. 
DOE Performance Indicators - EG\&G Idaho, Inc.

\subsection{ENVIRONMENT}

\subsection{Radlonucllde Effluent}

\subsubsection{Alrborne}

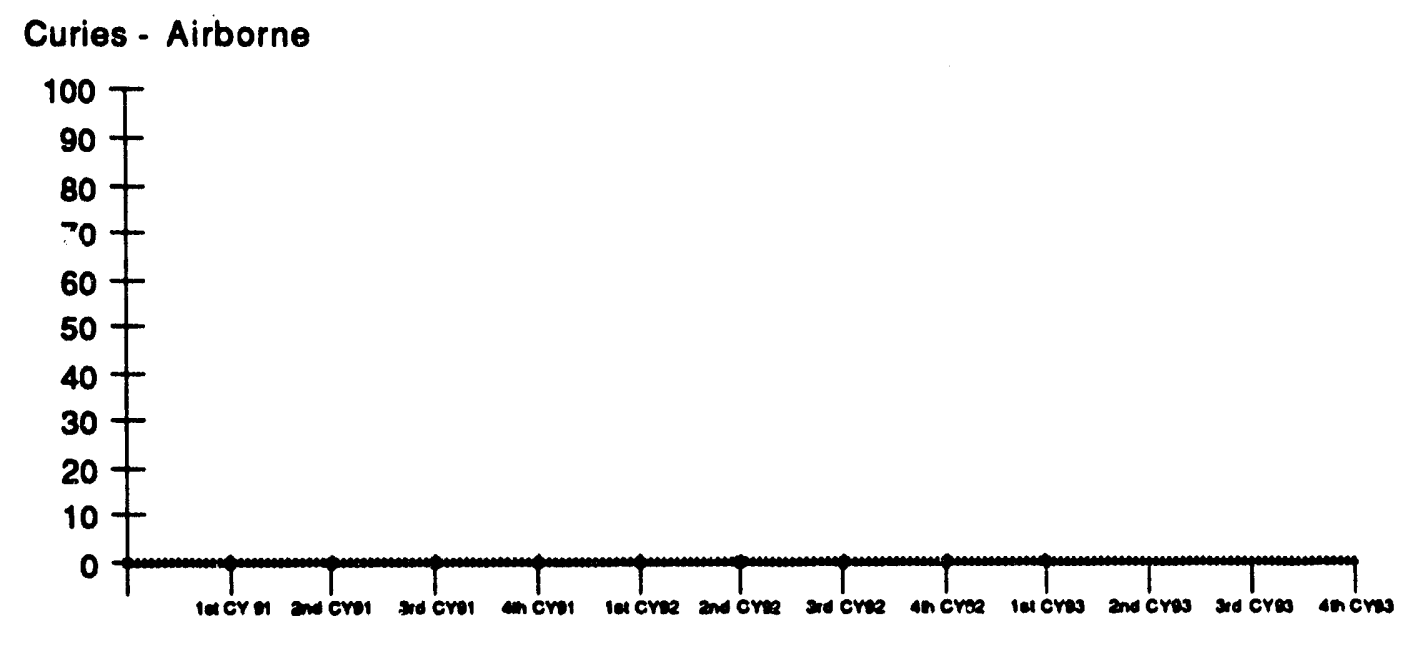

Time

- No airborne radionuclide effluent was released from the WERF during the first quarter of 1993.

\subsubsection{Llauld}

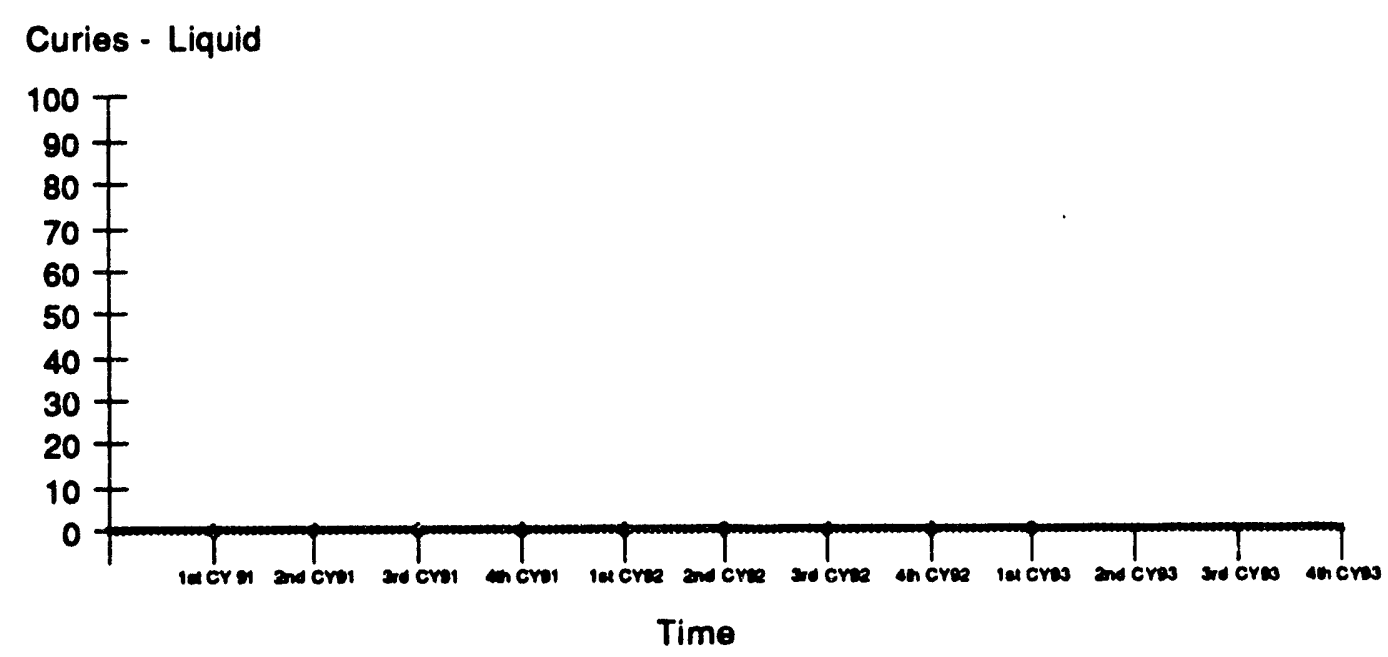

- No liquid radionuclide effluent was released from the WERF during the first quarter of 1993. 


\subsection{Hazardous Substance/Requlated Pollutant Effluent}

\subsubsection{Alrberne}

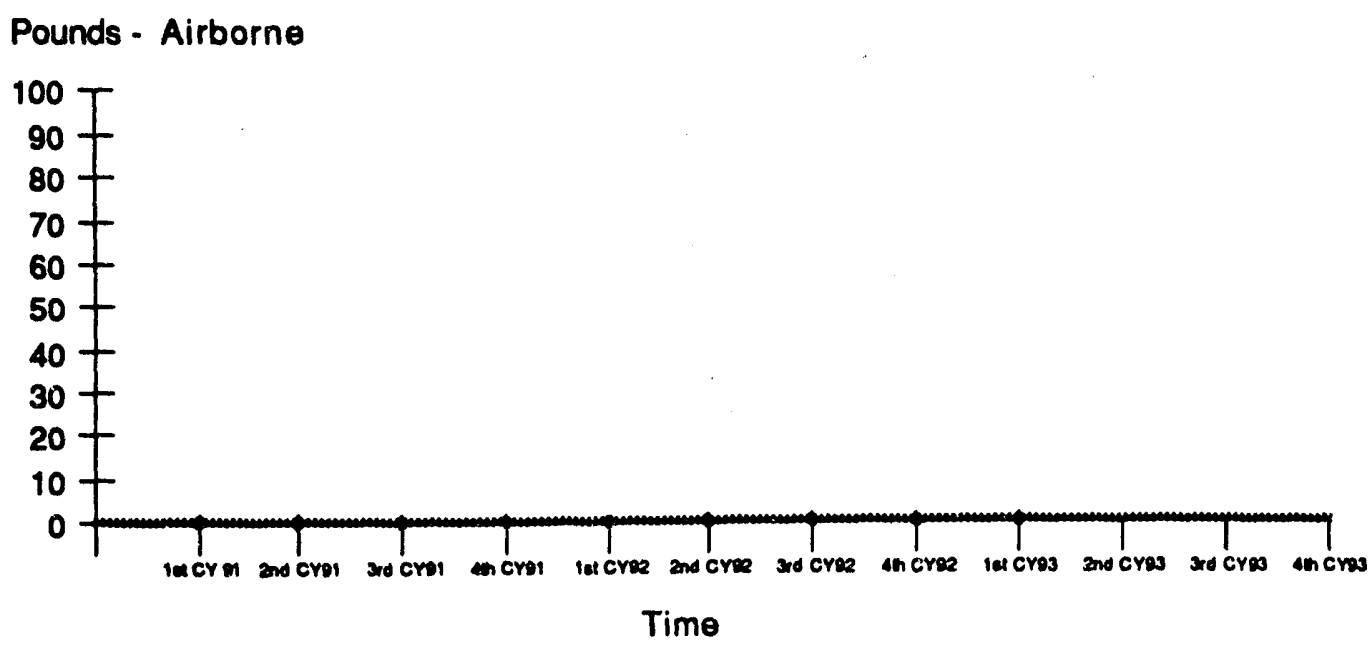

No airborne hazardous substances or regulated pollutants were released by the WERF during the first quarter of 1993.

\subsubsection{Hould}

Liquid - Gallons

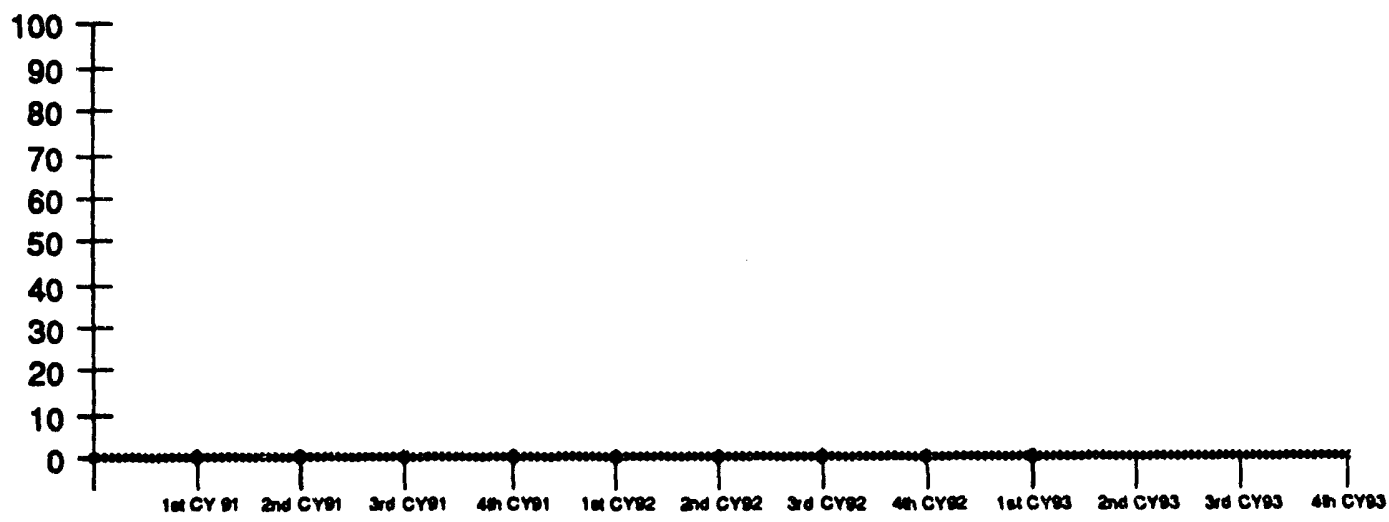

Time

No liquid hazardous substances or regulated pollutants were released by the WERF during the first quarter of 1993. 


\subsection{Environmental Jucldents}

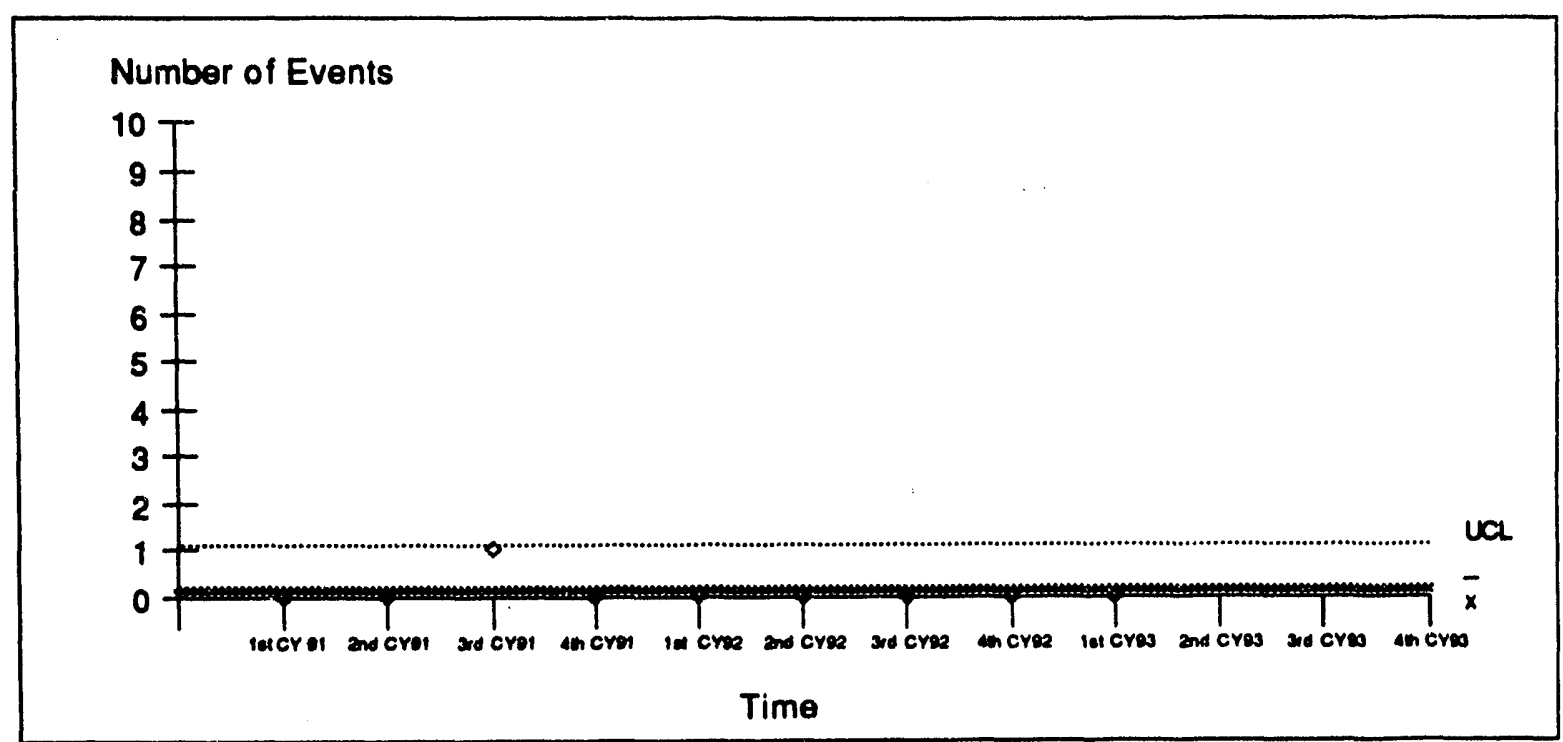

- No environmental incidents occurred at the WERF during the first quarter of 1993.

\subsection{Solld Low Level Waste Generated}

\subsubsection{Badloactlye Waste}

Cubic Feet

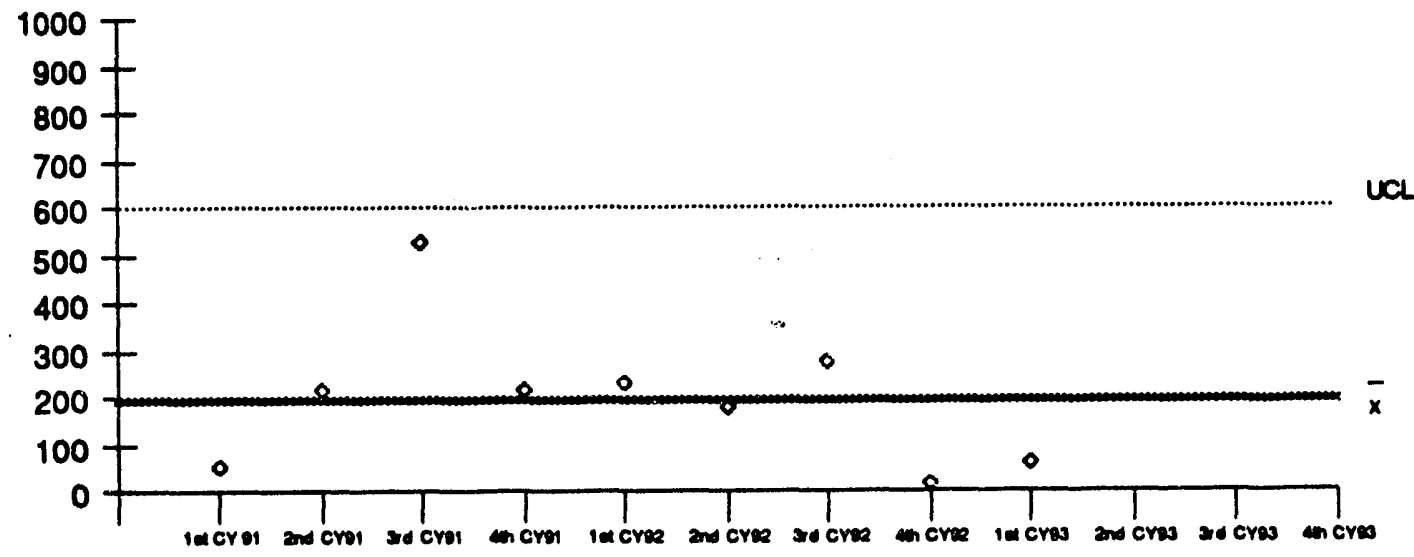

Time

- The first quarter of 1993 low level radioactive waste was generated by the WERF during incinerator refractory replacement. 


\subsubsection{Hazardous Waste}

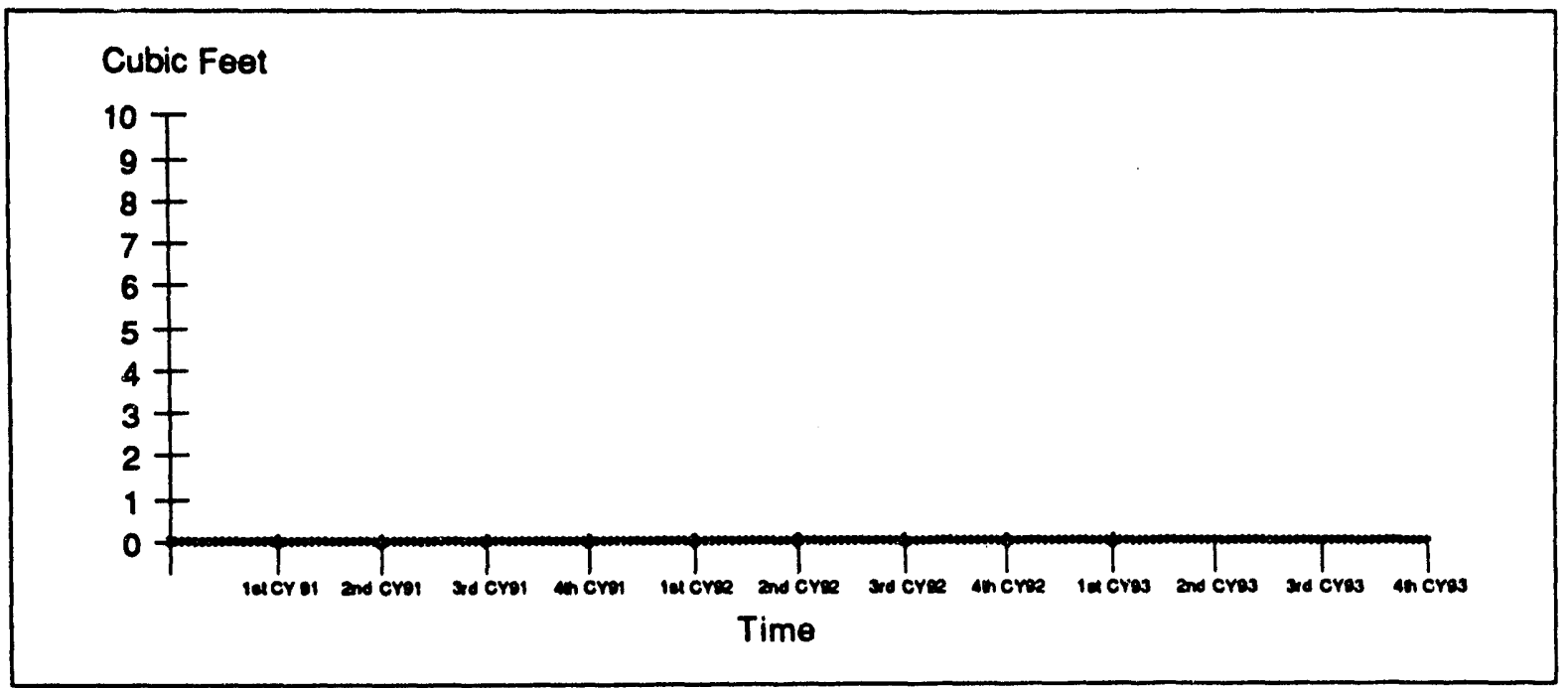

- No low level hazardous waste was generated by the WERF in the first quarter of CY 1993.

\subsubsection{Mlxed Waste}

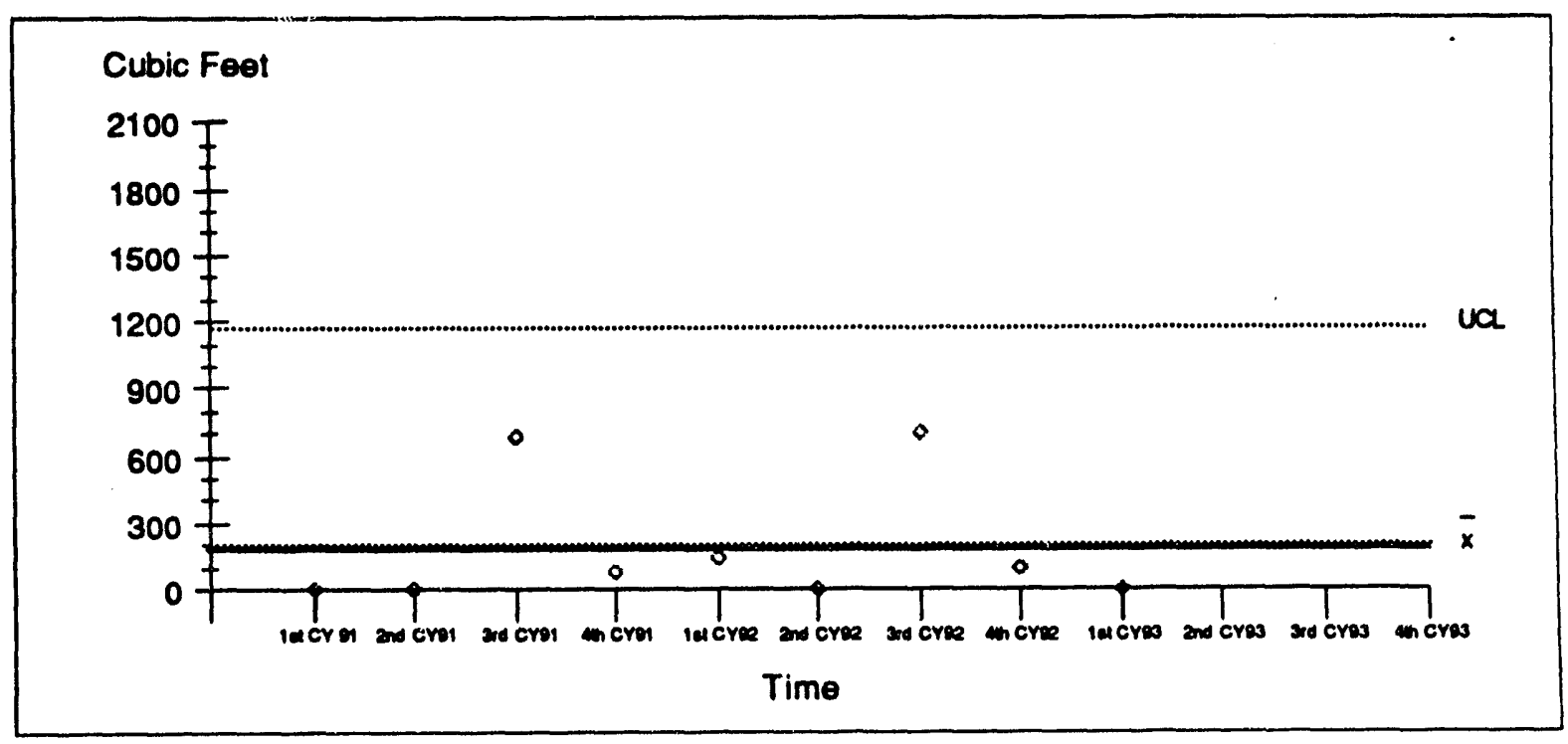

- No low level mixed waste was generated by the WERF in the first quarter of CY 1993. 


\subsection{MANAGEMENT}

\subsection{OSH Noncompllance}

Number of Events

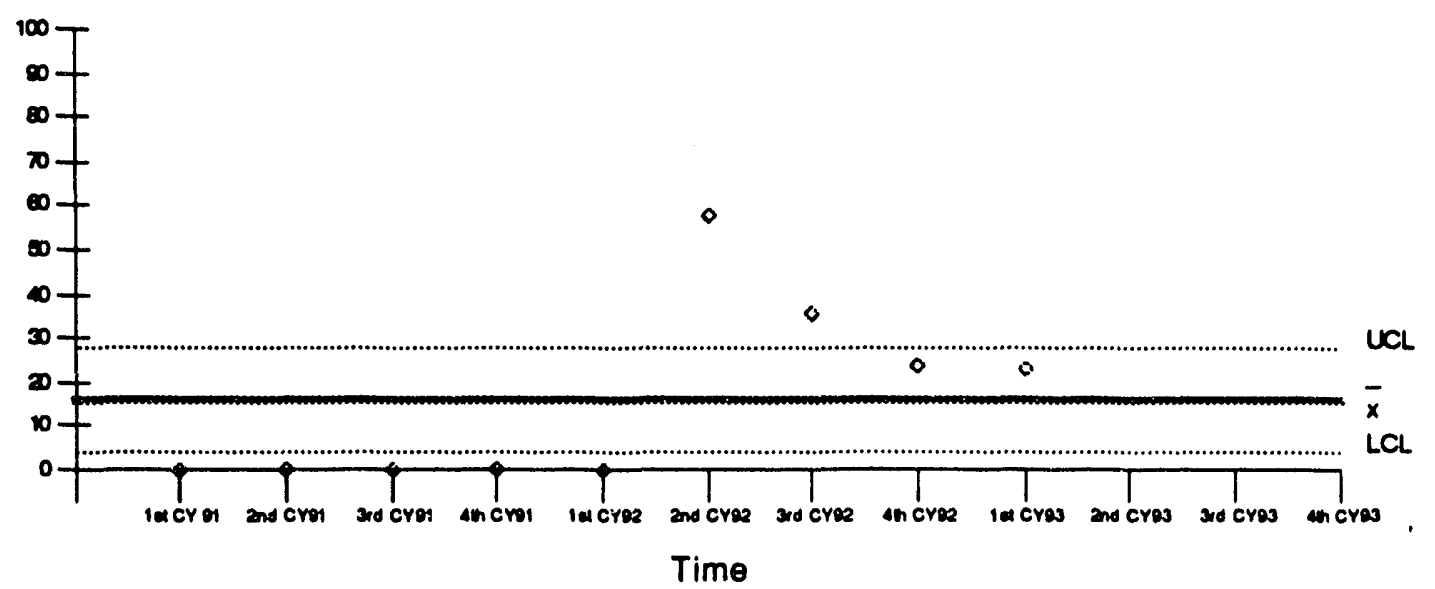

This indicator was changed from the number of OSH violations identified at the facilities during the quarter to the number of OSH noncompliances open greater than 90 days for the contractor at the end of the quarter. It was not possible to backfit this indicator as the information has been kept as the number of issues identified during the current quarter rather than the number of issues open greater than 90 days. The information on the graph is of two types. The first eight data points (CY-91 and CY-92) are facility totals of issues identified during the quarter, while the final data point (first quarter of 1993) is the facility total of issues open greater than 90 days. The number of OSH violations decreased from 24 identified in the fourth quarter of 1993 to 23 issues that remained open greater than 90 days at the end of the first quarter of 1993. No conclusions can be made about the WERFs performance based on the difference in the way the data points have been derived. All of the open items are ranked as low priority.

\subsection{Correctlve Malntenance Backlog}

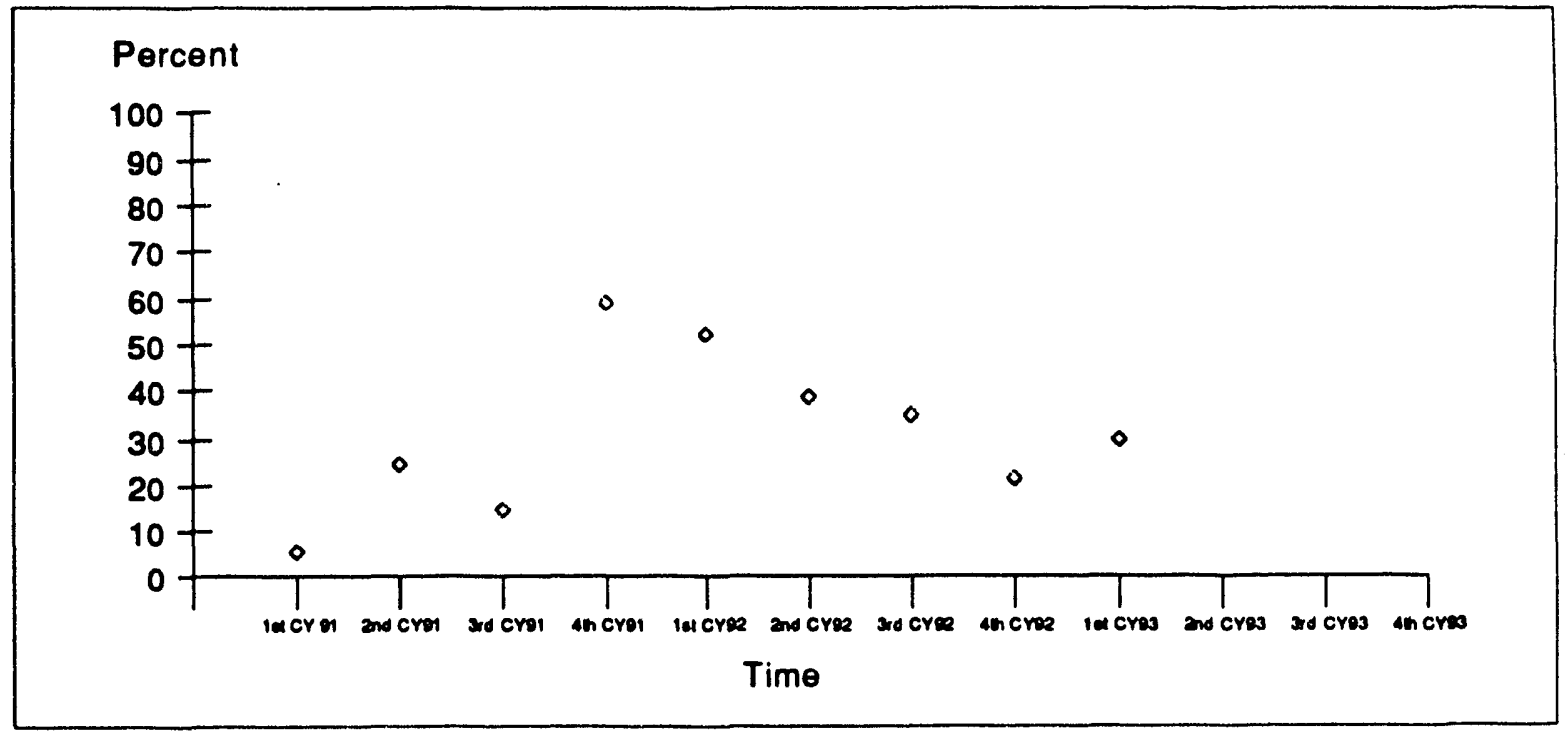

- During the fourth quarter of 1992 at the WERF there were 32 CM items open greater than three months versus a total of 150 open $(21 \%)$. For the first quarter of 1993 , the total number of open items increased to 132, with $39 \mathrm{CM}$ items open longer than three months (30\%). The number of items open greater than 90 days increased slightly because of efforts to comply with DOE Order $4330.3 \mathrm{~A}$ while getting the WERF ready for restart. 


\subsection{Preventlve Maintenance Overdue}

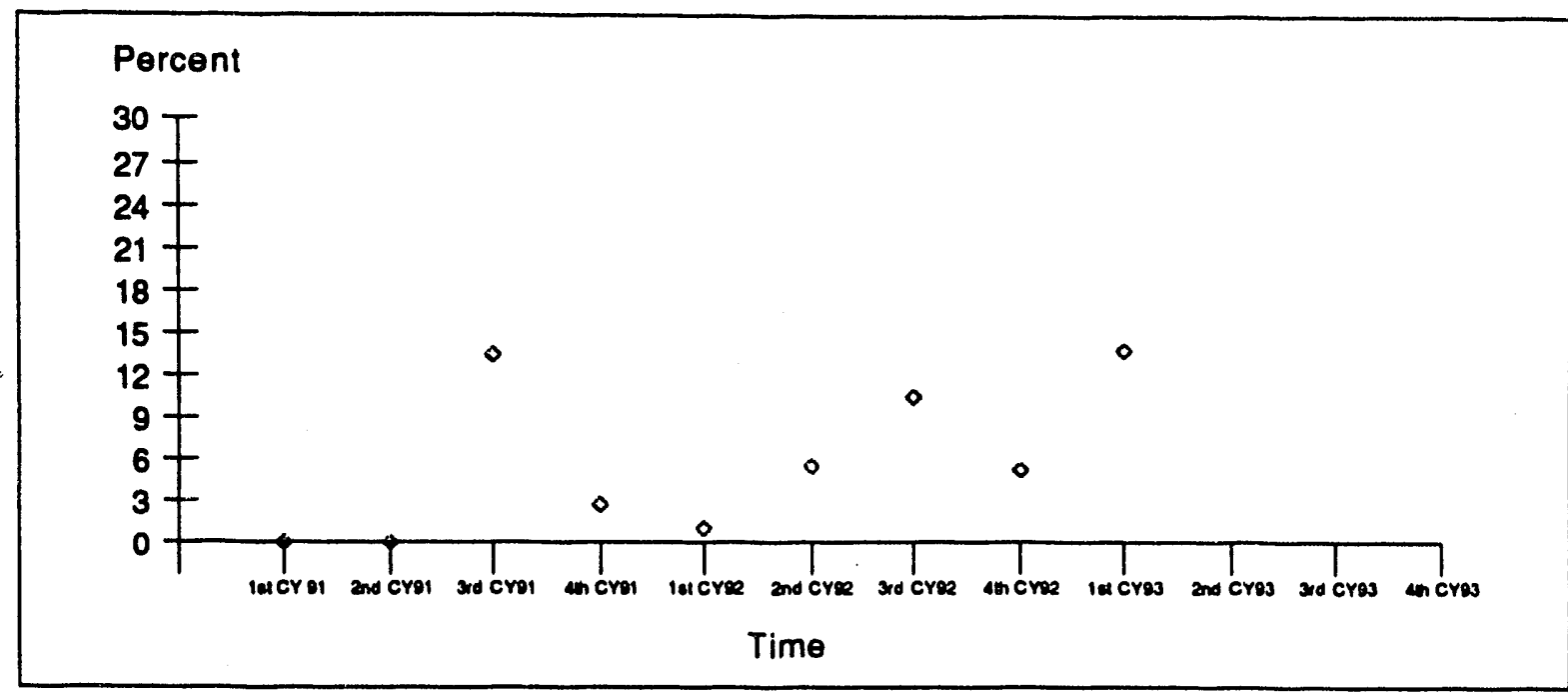

- During the fourth quarter of 1992 at the WERF, 5.1\% of the scheduled PM items were not completed within the originally scheduled interval (18 of 352 ). For the first quarter of $1993,13.8 \%$ of the scheduled PM items were not completed within the originally scheduled interval (20 of 145). The number of items open greater than 90 days increased slightly because of efforts to comply with DOE Order $4330.3 \mathrm{~A}$ while getting the WERF ready for restart.

\subsection{Occurrence Reports With Open Correctlve Actions}

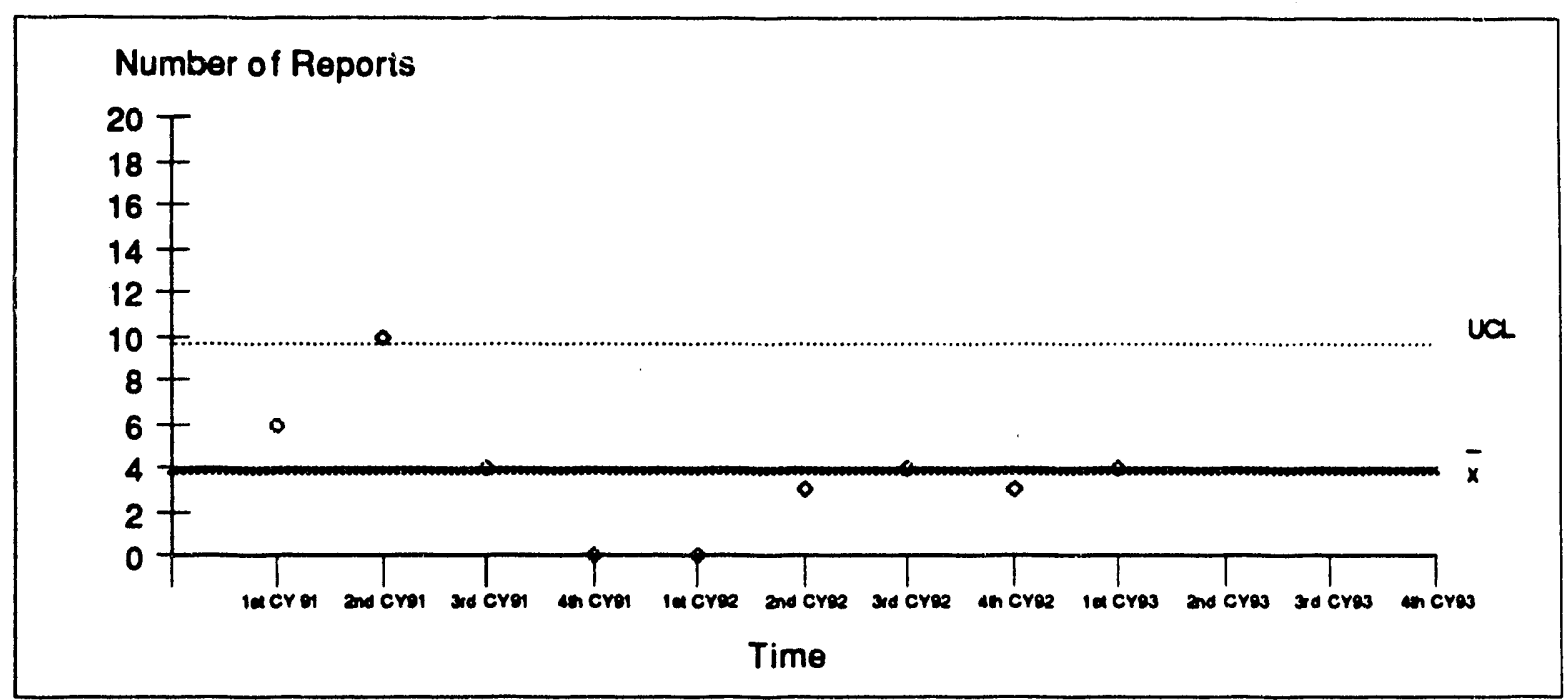

At the close of the first quarter, 4 Final Occurrence Reports (ORs) had open corrective actions at the WERF. The increased number of occurrence reports reflects the increased emphasis on finalizing ORs. 


\section{Appendix E - Performance Indicator Charts for the TRA Hot Cells Facility}

This appendix provides charts and descriptions of performance indicators for the TRA Hot Cells facility performance. The performance indicators are identified consistent with the numbering in DOE-STD-1048-92. Note that PIs 1.5, 1.6, 2.5, 4.1, and 4.2 are only reported at the contractor level and are not included in the facility appendices.

\subsection{PERSONNEL SAFETY}

\subsection{Collectlve Radiation Dose}

\subsubsection{Shallow Dose}

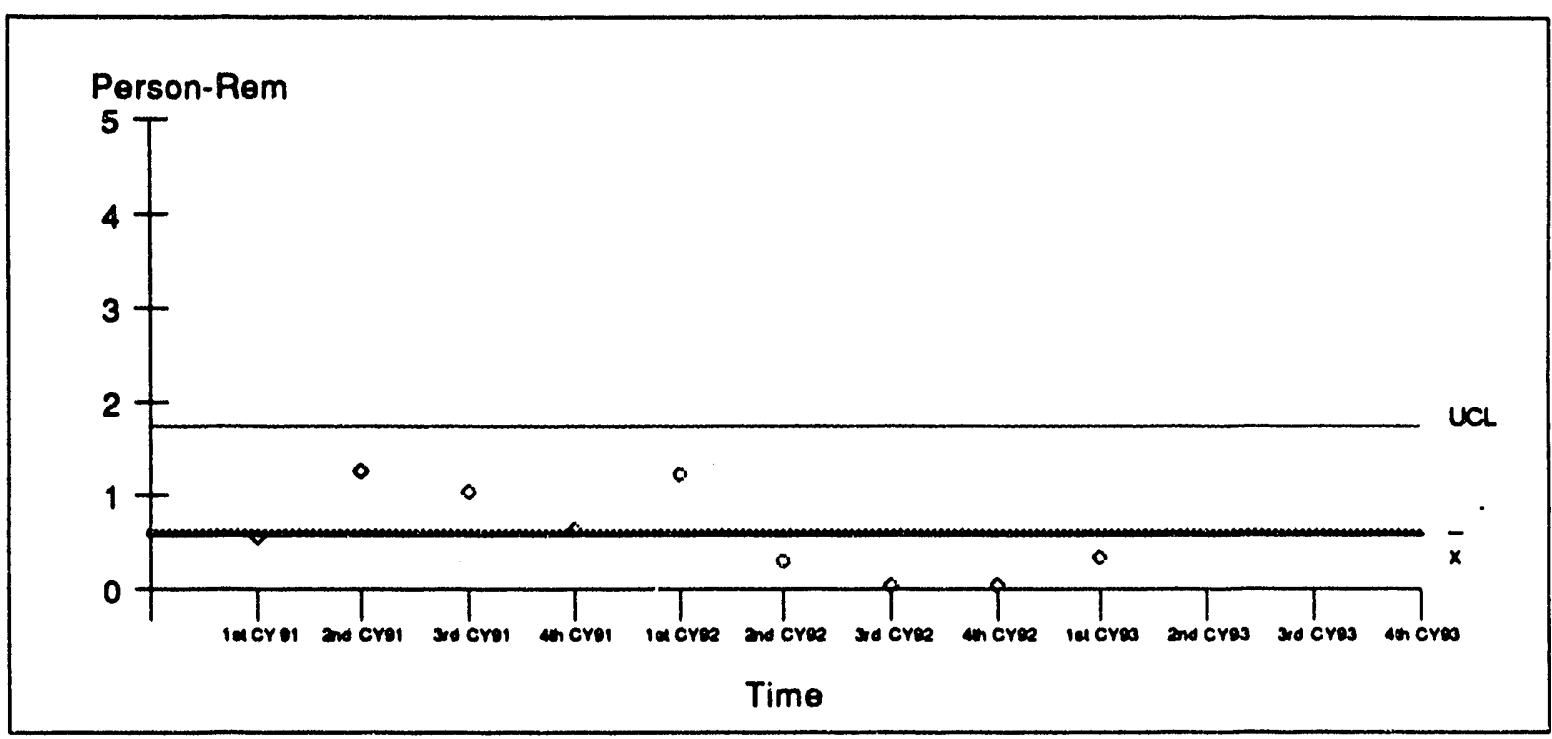

- The radiation exposures remain at levels below the ALARA goals for the year.

\subsubsection{Deep Dese}

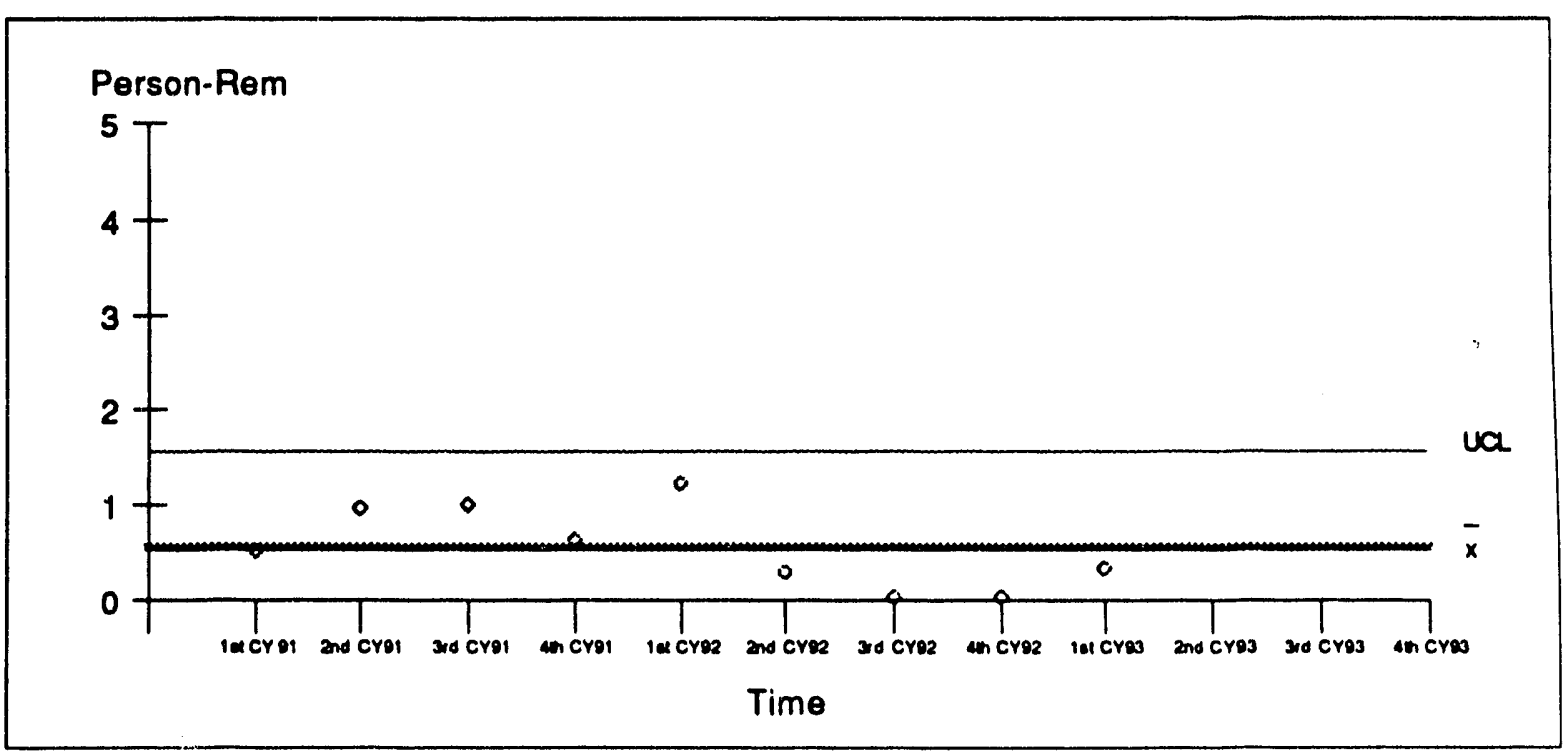

The radiation exposures remain at levels below the ALARA goals for the year. 


\subsection{Skin/Clothing Contaminations}

Number of Events

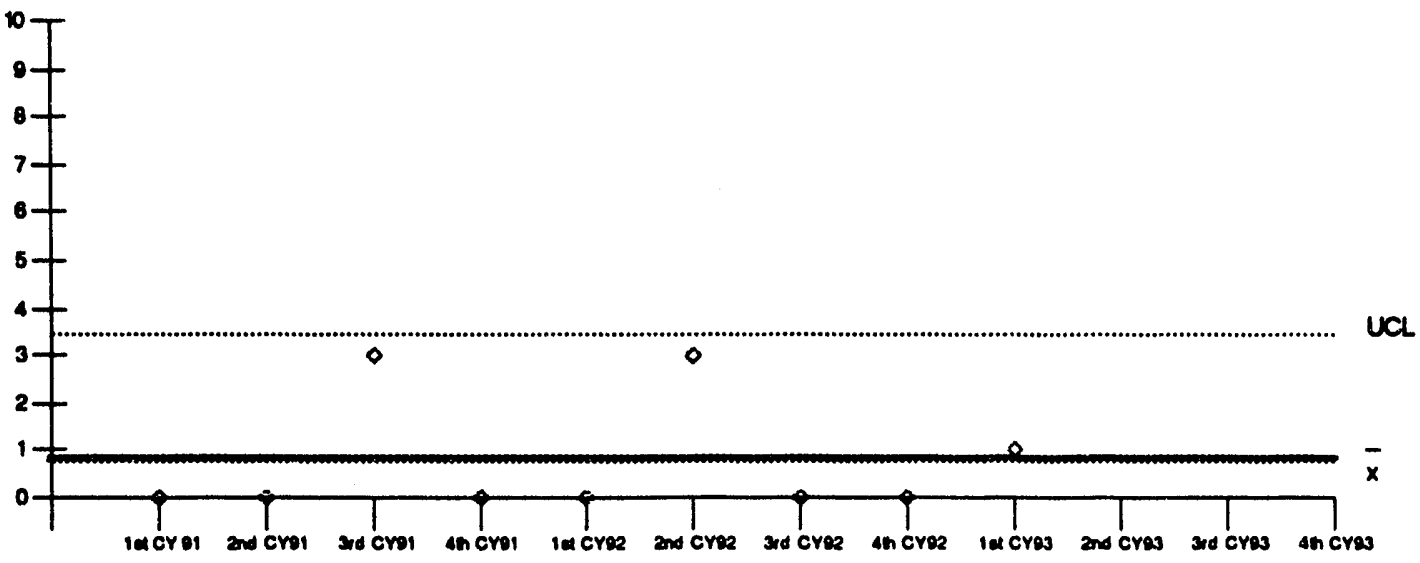

Time

- A single skin/clothing contamination event occurred at the TRA Hot Cells during the first quarter of 1993. The event was attributed to inadequate procedures resulting in several particles being picked up on a worker's company furnished clothes during the discharge of a sample from the Hot Cells (ID--EGG-TRAHC1993-0002). The relatively low number of skin contamination events is reflective of the increased EG\&G radiological control activities.

\subsection{Internal Contaminatlons}

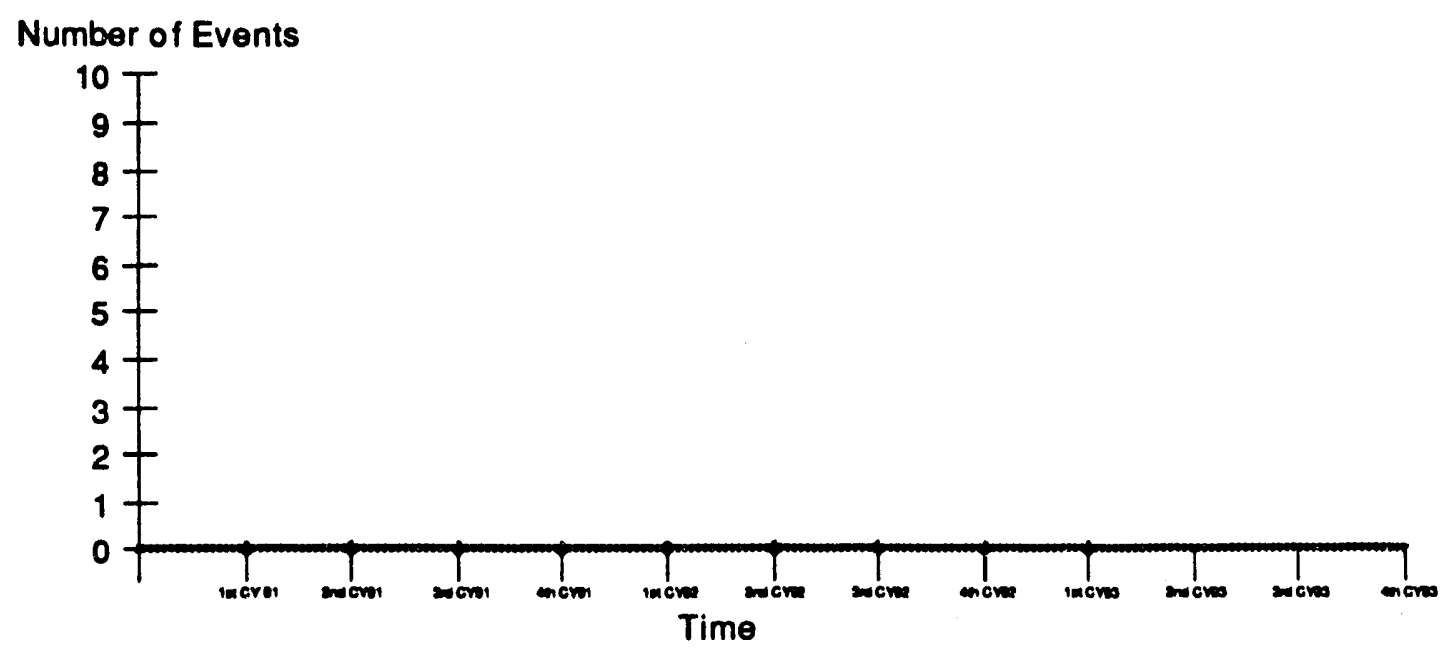

- No internal contamination events occurred at the TRA Hot Cells during the first quarter of 1993. 


\subsection{Radloactlve Or Hazardous Materlal Overexposures}

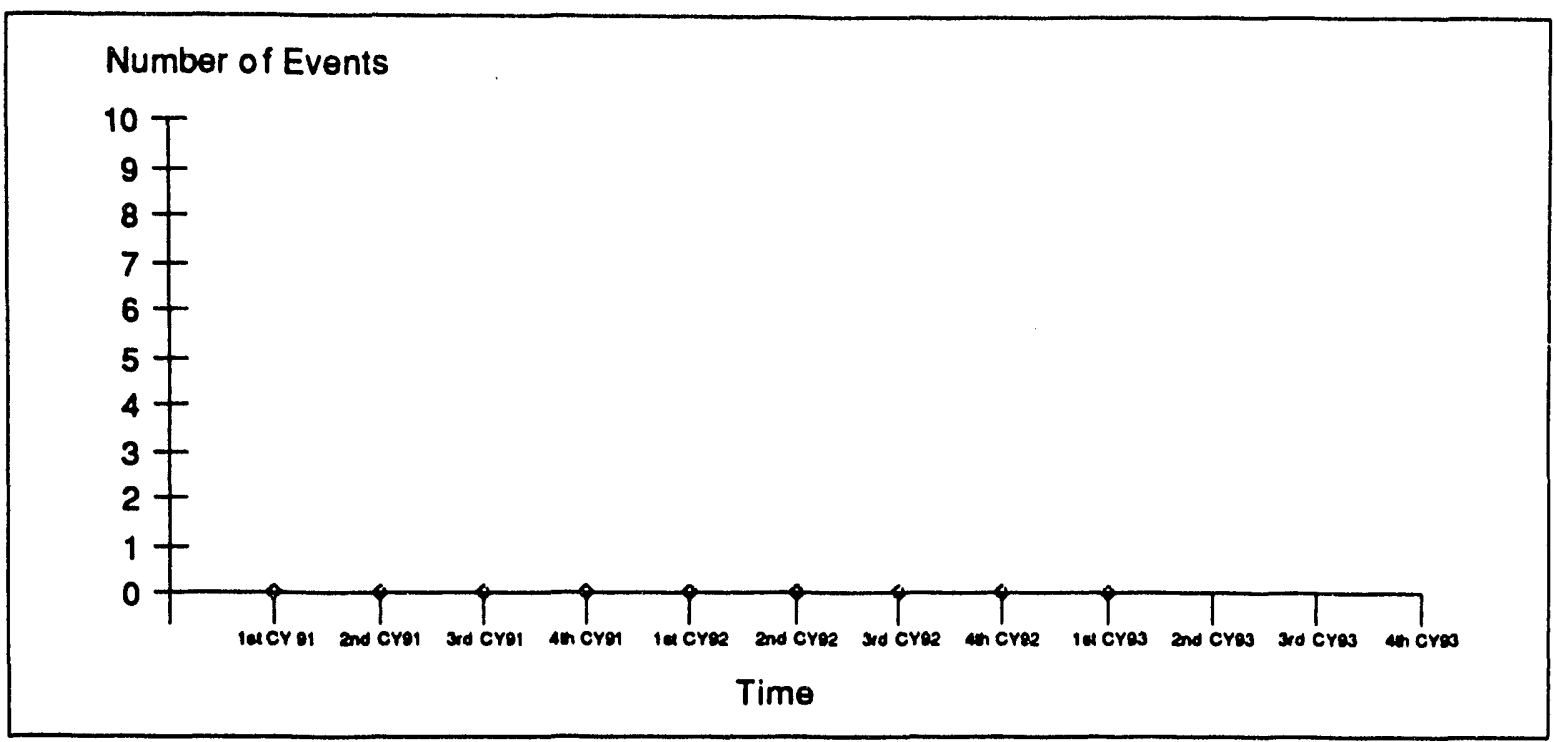

No radioactive or hazardous material overexposures occurred at the TRA Hot Cells during the first quarter of 1993. 


\subsection{OPERATIONAL INCIDENTS}

\subsection{Unplanned Safety Function Actuations}

Number of Events

$\begin{aligned} & 10 \\ & 9 \\ & 8 \\ & 7 \\ & 6 \\ & 5 \\ & 4 \\ & 3 \\ & 2 \\ & 1 \\ & 0\end{aligned}-$ I
f
f
f
t

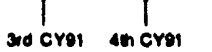

1at Cyo2

Time

- No unplanned safety function actuations occurred at the TRA Hot Cells during the first quarter of 1993.

\subsection{Vlolations of Operating Procedures}

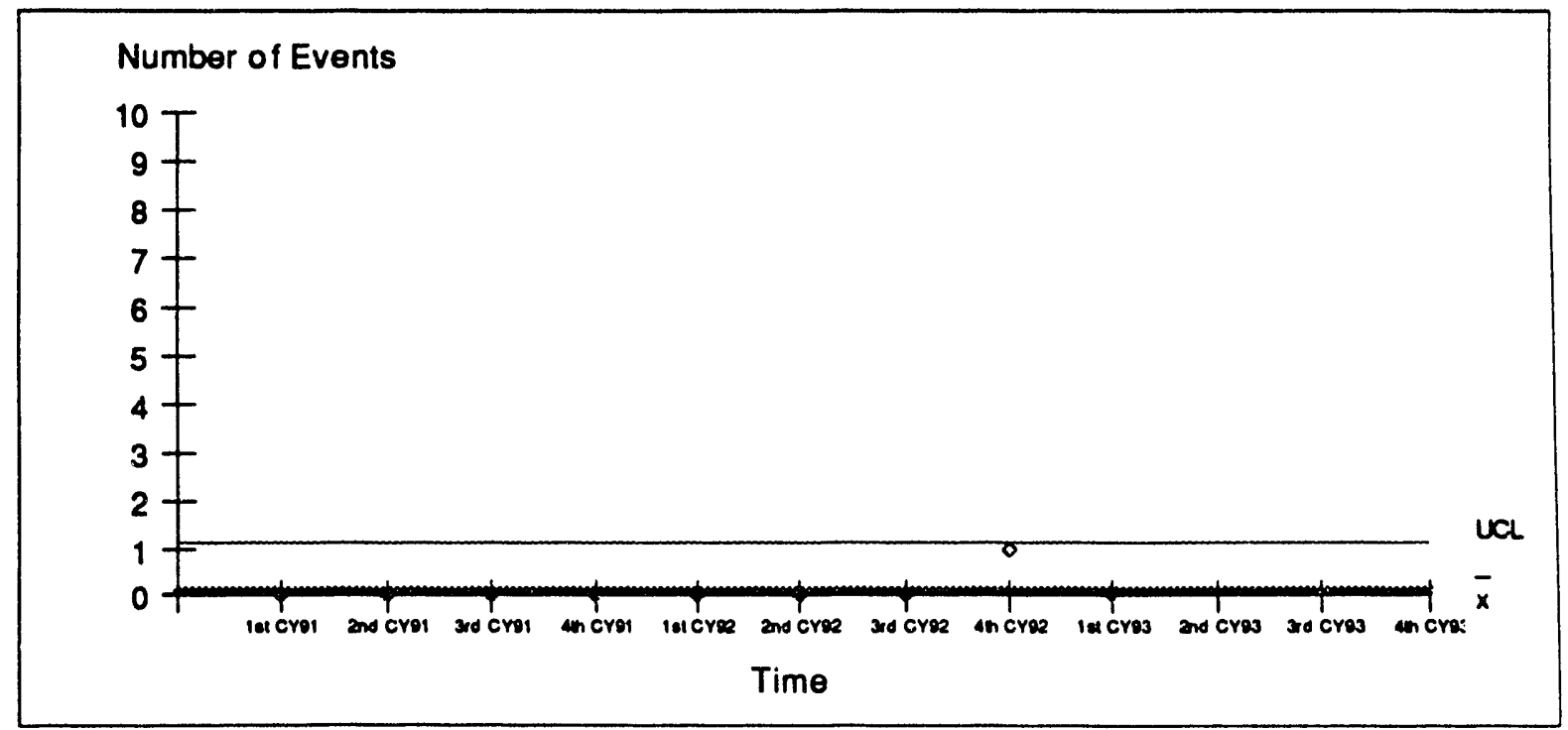

- No violations of operating procedures occurred at the TRA Hot Cells during the first quarter of 1993. 


\subsection{Unolanned Shutdowns}

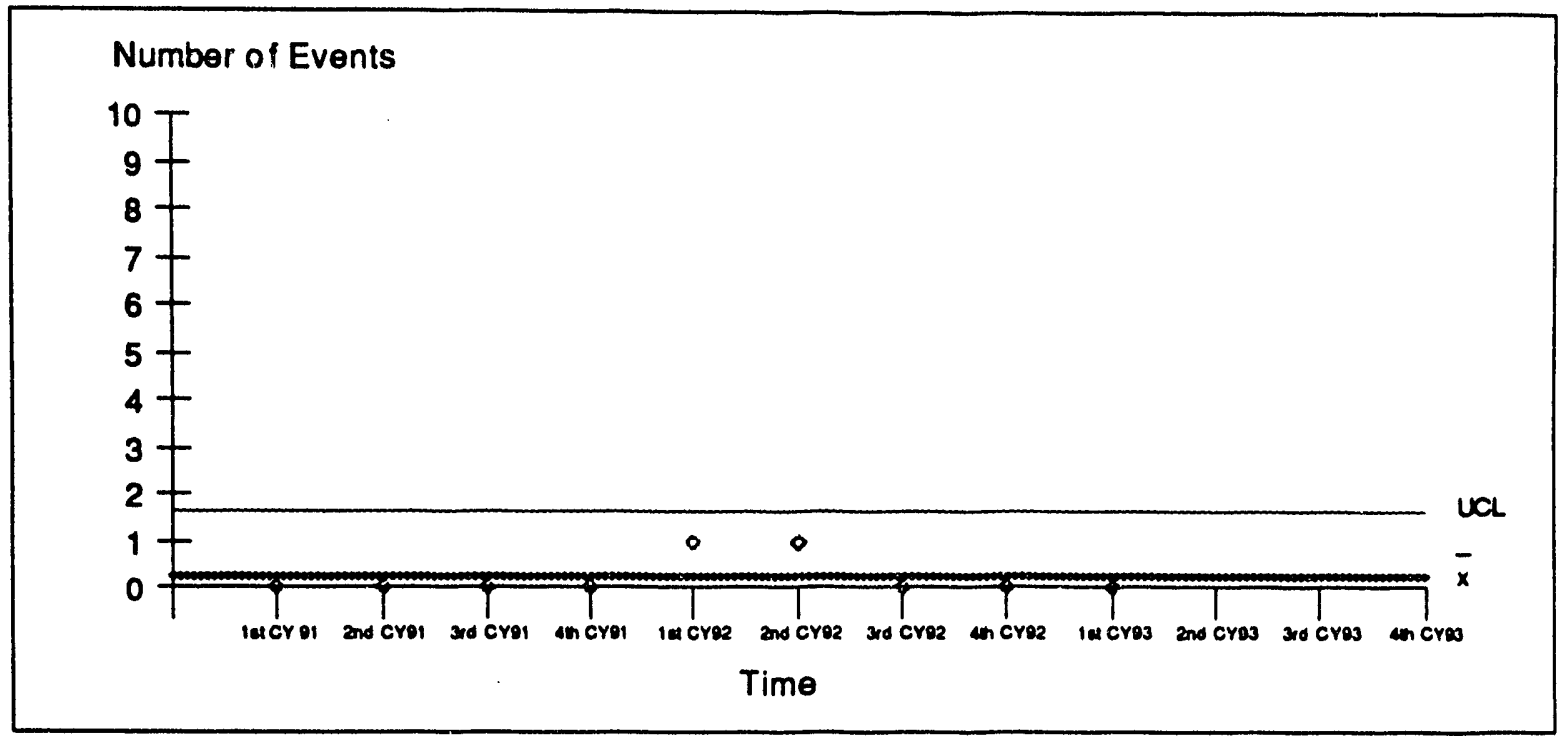

- No unplanned shutdowns occurred at the TRA Hot Cells during the first quarter of 1993.

\subsection{Emergency And Unusual Occurrences}

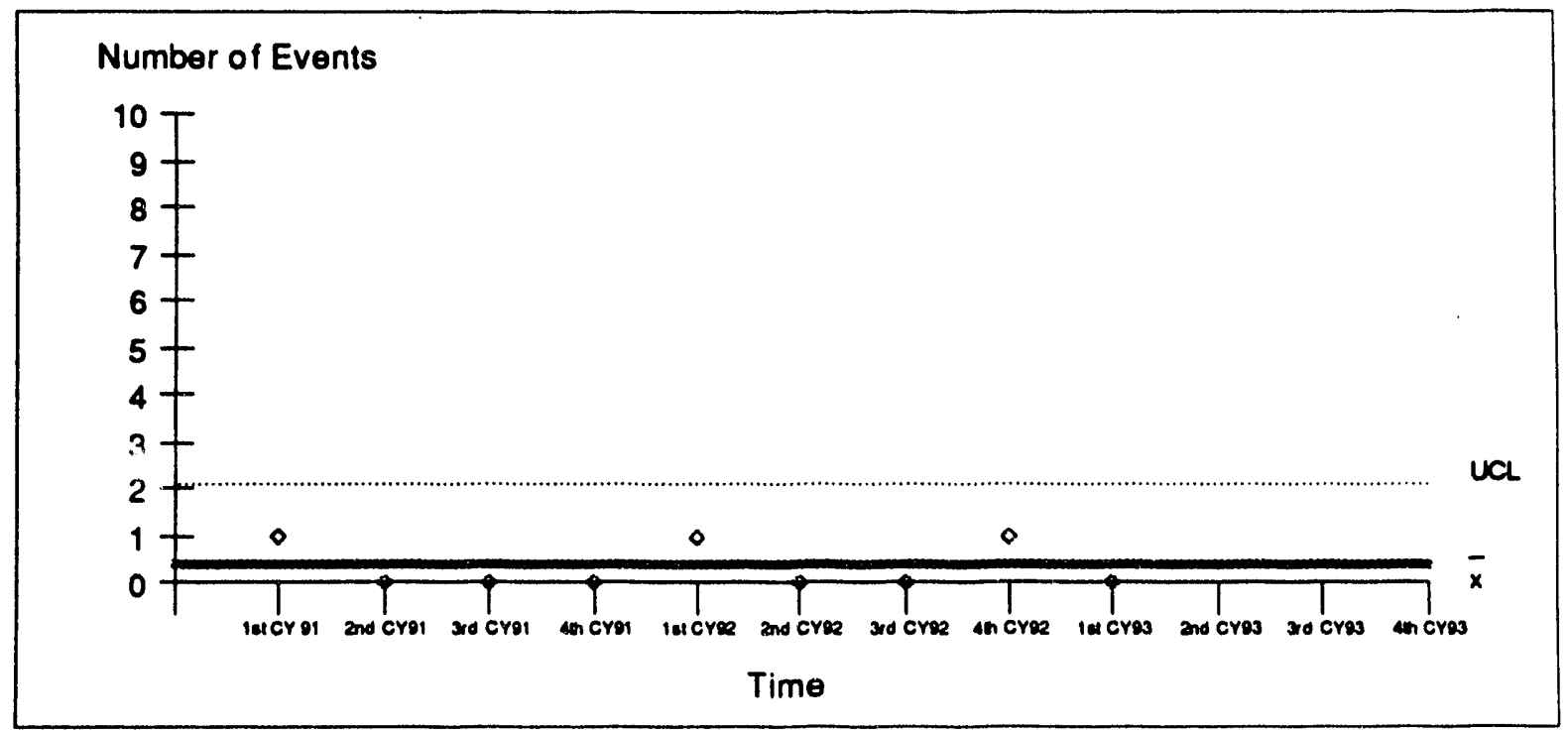

- No emergency or unusual occurrences occurred at the TRA Hot Cells during the first quarter of 1993. 


\subsection{ENVIRONMENT}

\subsection{Radlonuclide Effluent}

\subsubsection{Alrborne}

\section{Curies - Airborne}

1.00E-06

9.00E-07 -

8.00E-07 -

7.00E-07

$6.00 E-07-$

5.00E-07 -

4.00E-07 -

3.00E-07 -

2.00E-07

1.00E-07

$0.00 E+00$

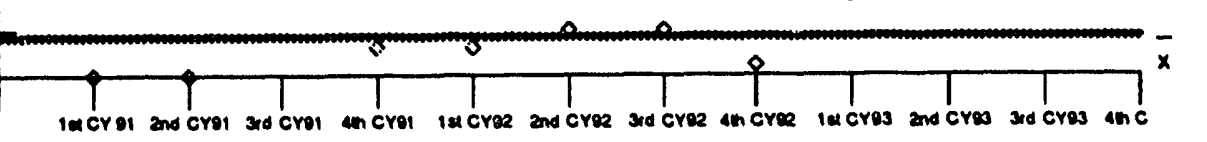

Time 


\subsection{Hazardous Substance/Regulated Pollutant Effluent}

\subsubsection{Alrberne}

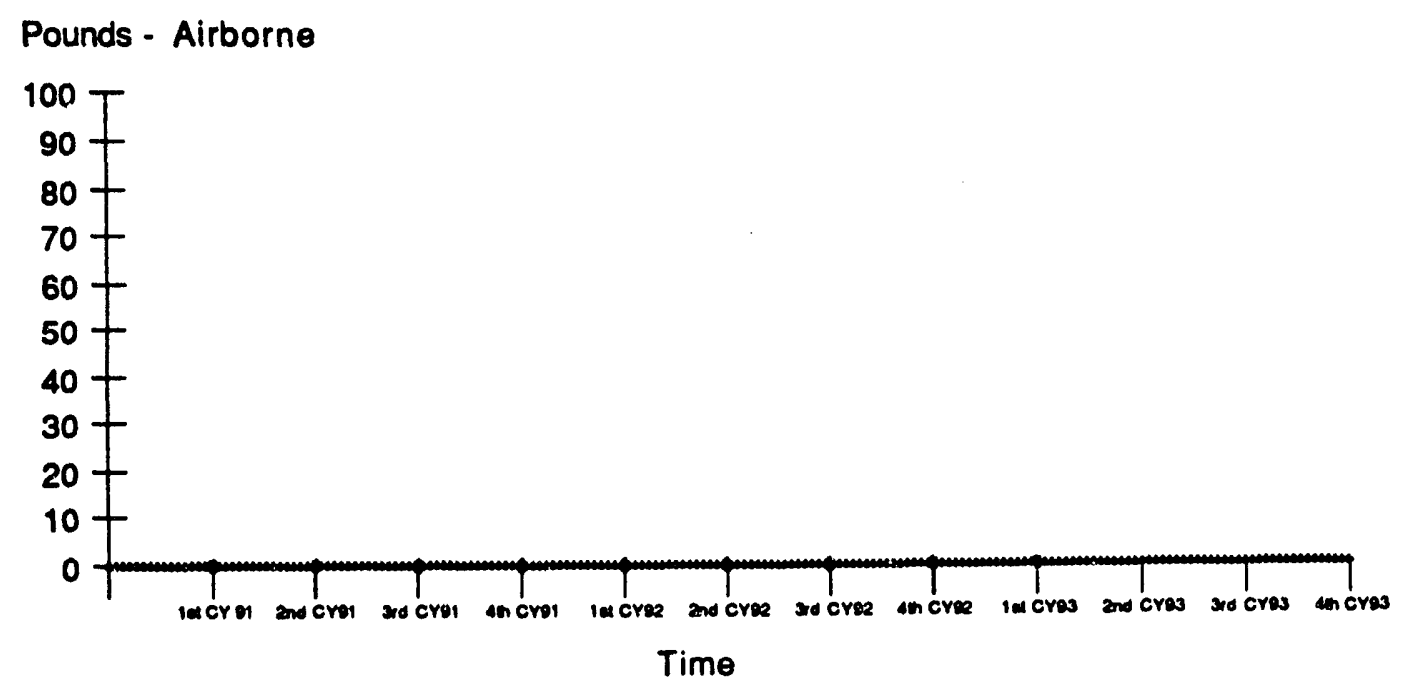

- No aiborr - hazardous substances or regulated pollutants were released by the TRA Hot Cells during the first quarte, of 1993.

\subsubsection{Hauld}

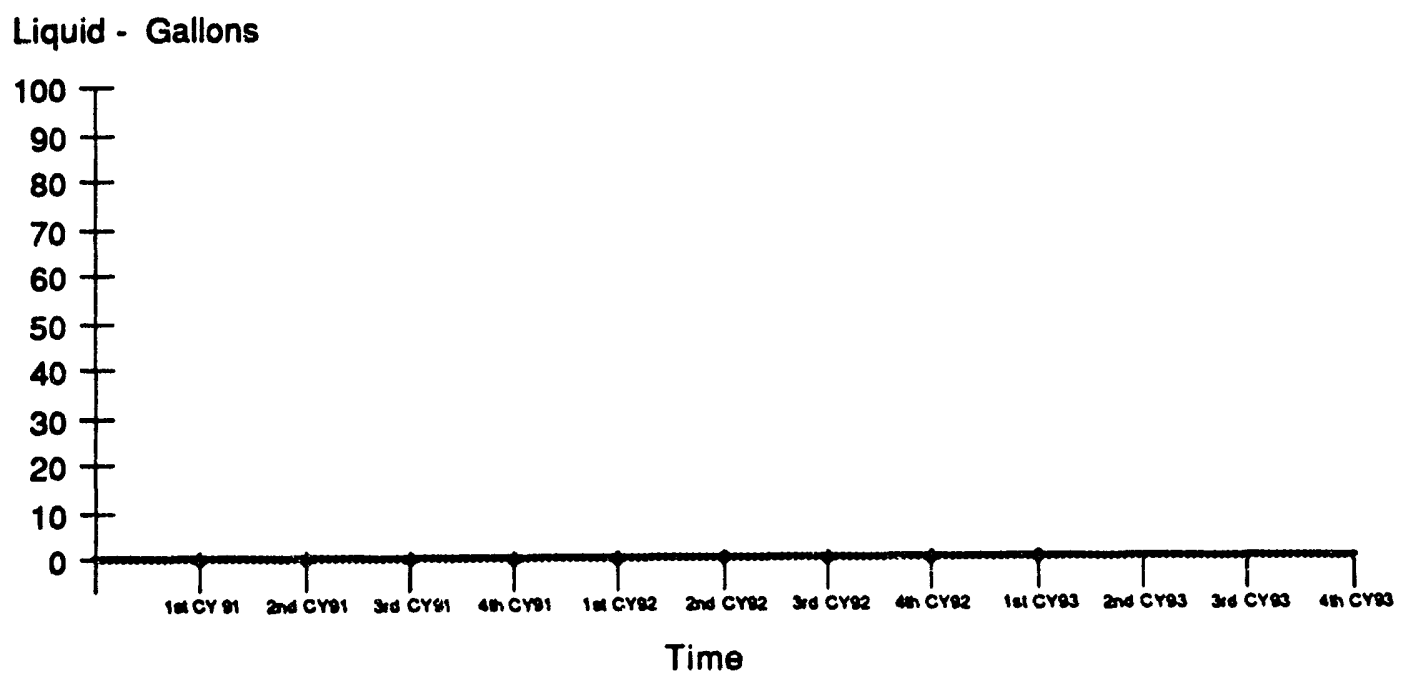

- No liquid hazardous substances or regulated follutants were released by the TRA Hot Cells during the first quarter of 1993. 


\subsection{Environmental_incidents}

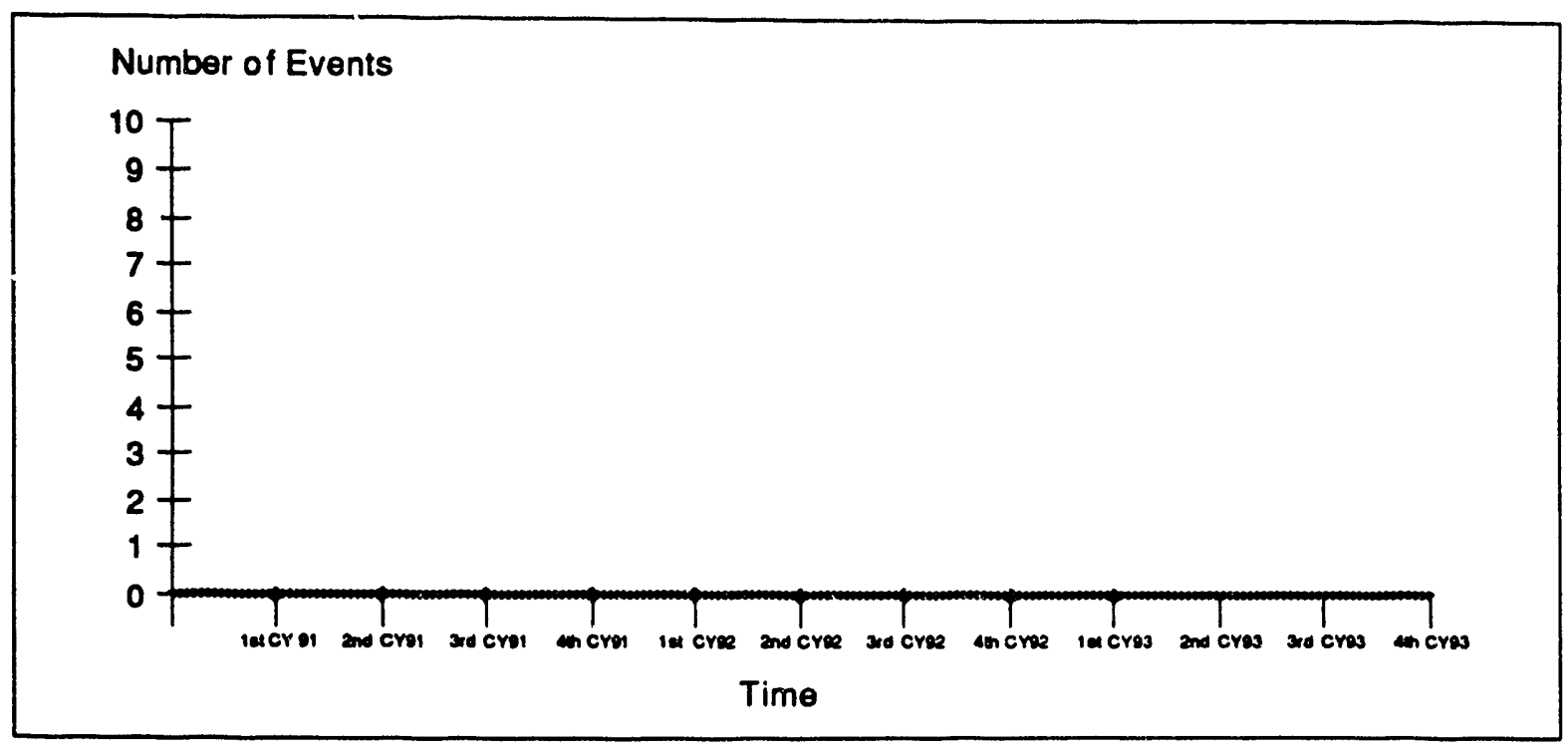

- No environmental incidents occurred at the TRA Hot Cells during the first quarter of 1993.

\subsection{Solld Low Level Waste Generated}

\subsubsection{Badloactlve Waste}

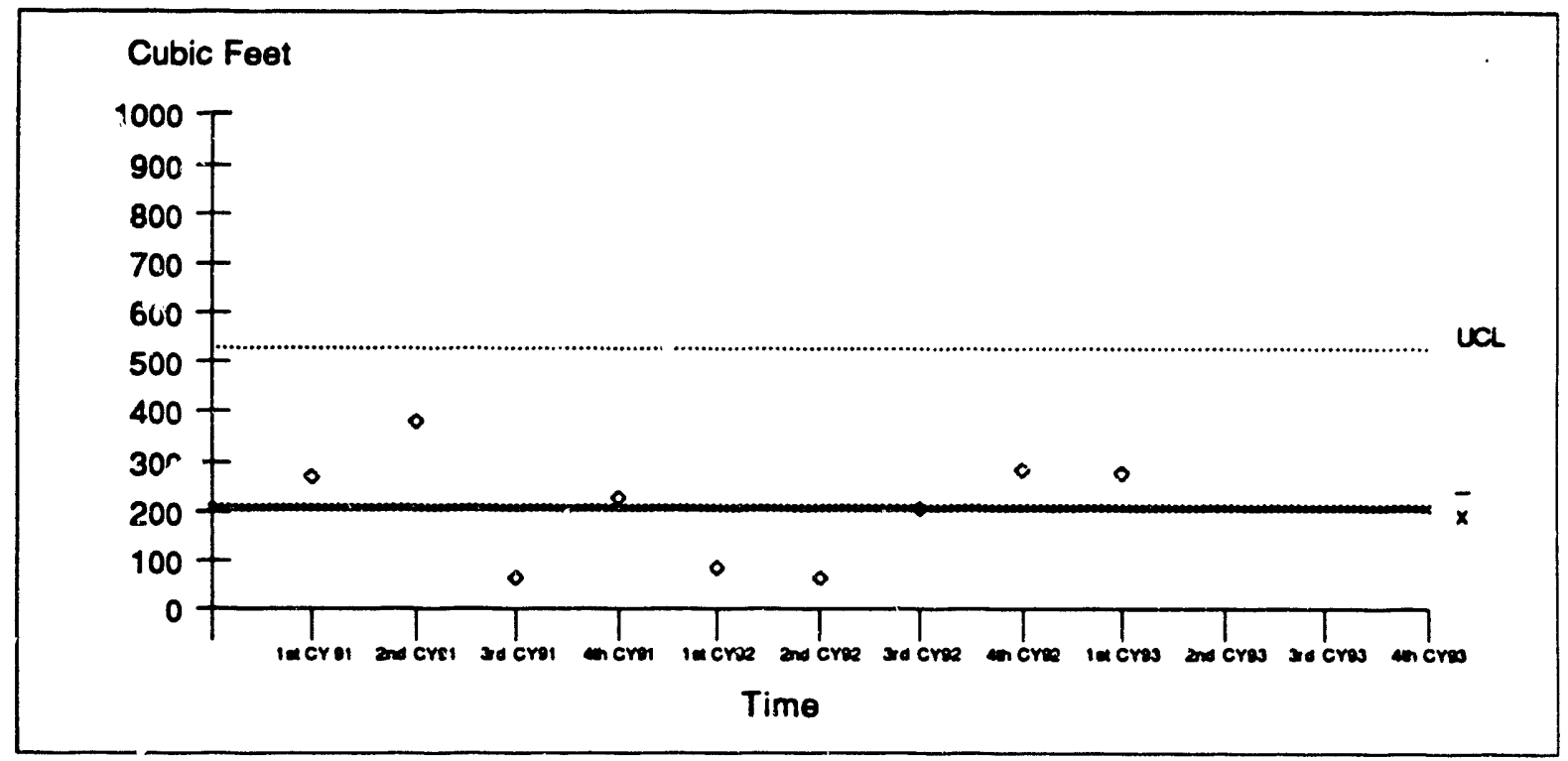

- The first quarter of 1993 low level radioactive waste was generated by the TRA Hot Cells during routine operations. 


\subsubsection{Hazardous Waste}

Cubic Feet

10
9
8
7
6
5
4
3
2
1
0

0
9
8
7
6
5
4
3
2
1
0

Time

- No bow level hazardous waste was generated by the TRA Hot Cells in the first quarter of CY 1993.

\subsubsection{Mlxed Waste}

Cubic Feet

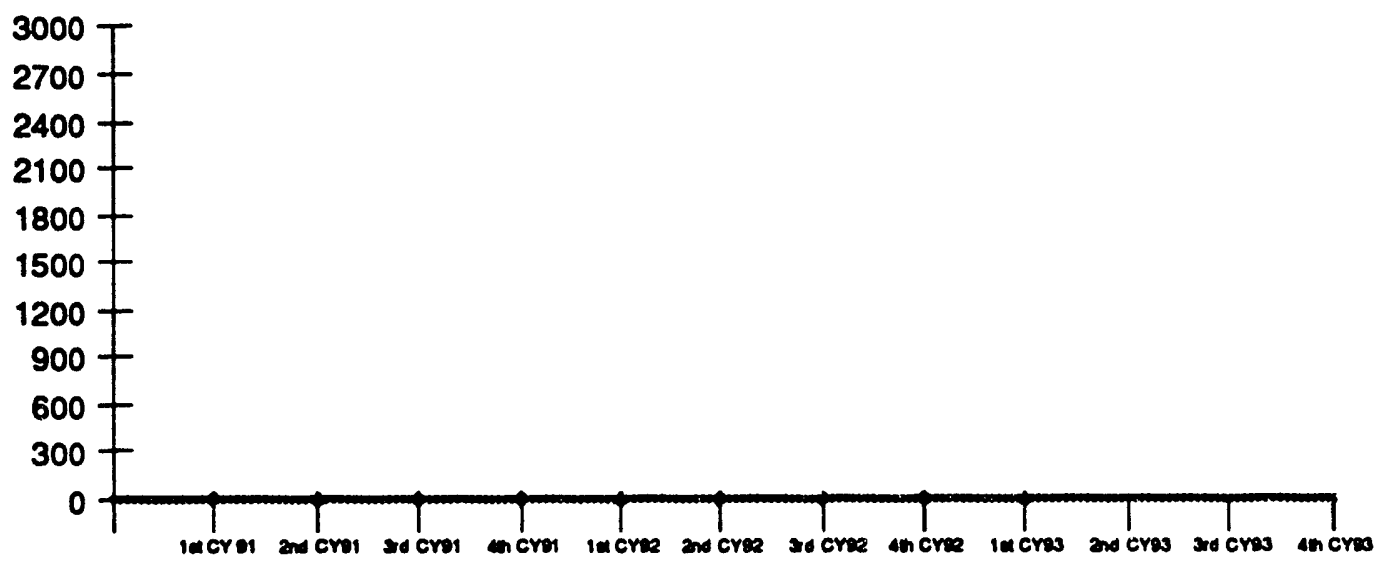

Time

- No low level mixed waste was generated by the TRA Hot Cells in the first quarter of CY 1993. 


\subsection{MANAGEMENT}

\subsection{OSH Noncompllance}

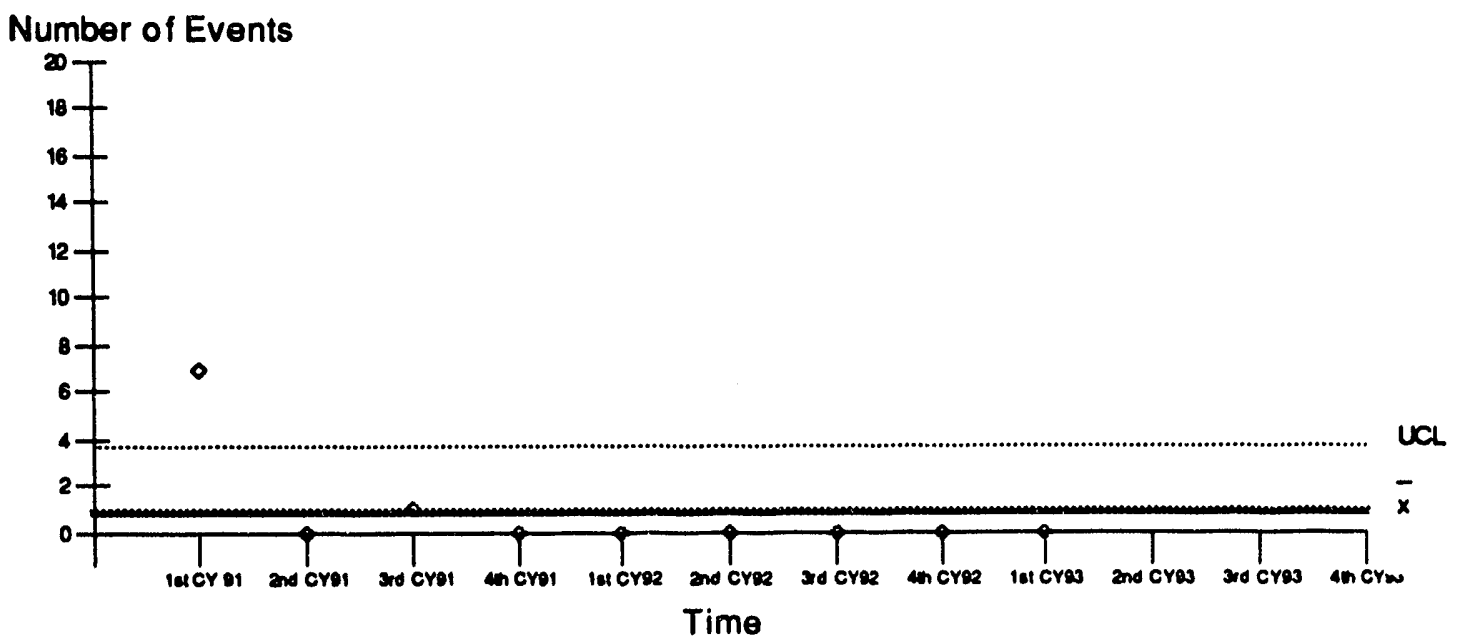

- This indicator was changed from the number of OSH violations identified at the facilities during the quarter to the number of OSH noncompliances open greater than 90 days for the contractor at the end of the quarter. It was not possible to backfit this indicator as the information has been kept as the number of issues identified during the current quarter rather than the number of issues open greater than 90 days. The information on the graph is of two types. The first eight data points (CY-91 and CY-92) are facility totals of issues identified during the quarter, while the final data point (first quarter of 1993) is the facility total of issues open greater than 90 days. No OSH violations remained open at the TRA Hot Cells in the first quarter of 1993.

\subsection{Correctlve Maintenance Backlog}

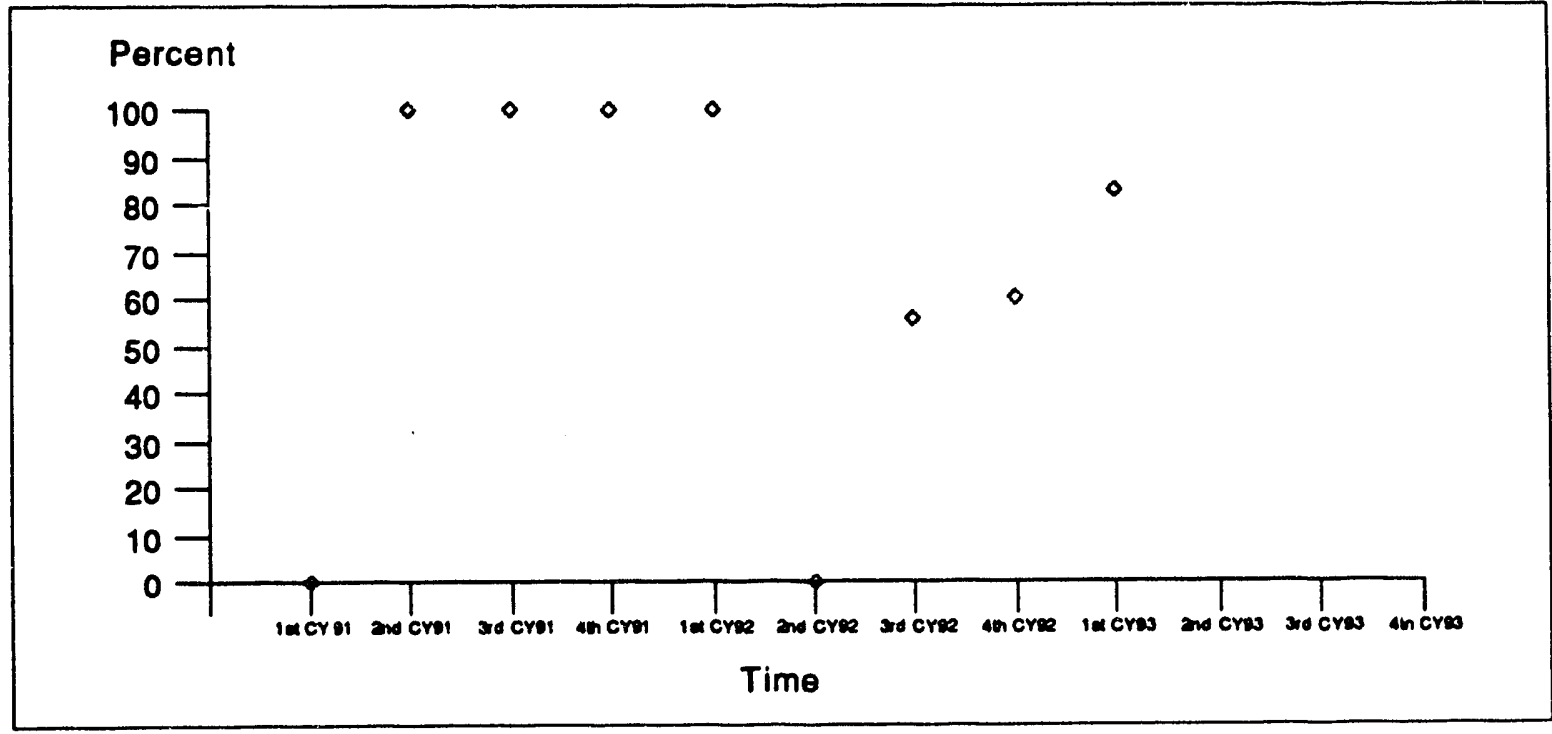

During the fourth quarter of 1992 at the TRA Hot Cells there were 6 CM items open greater than three menths versus a total of 10 open $(60 \%)$. For the first quarter of 1993, the total number of open items decreased to 6 , with $5 \mathrm{CM}$ items open longer than three months (83\%). 


\subsection{Preventlve Malntenance Overdue}

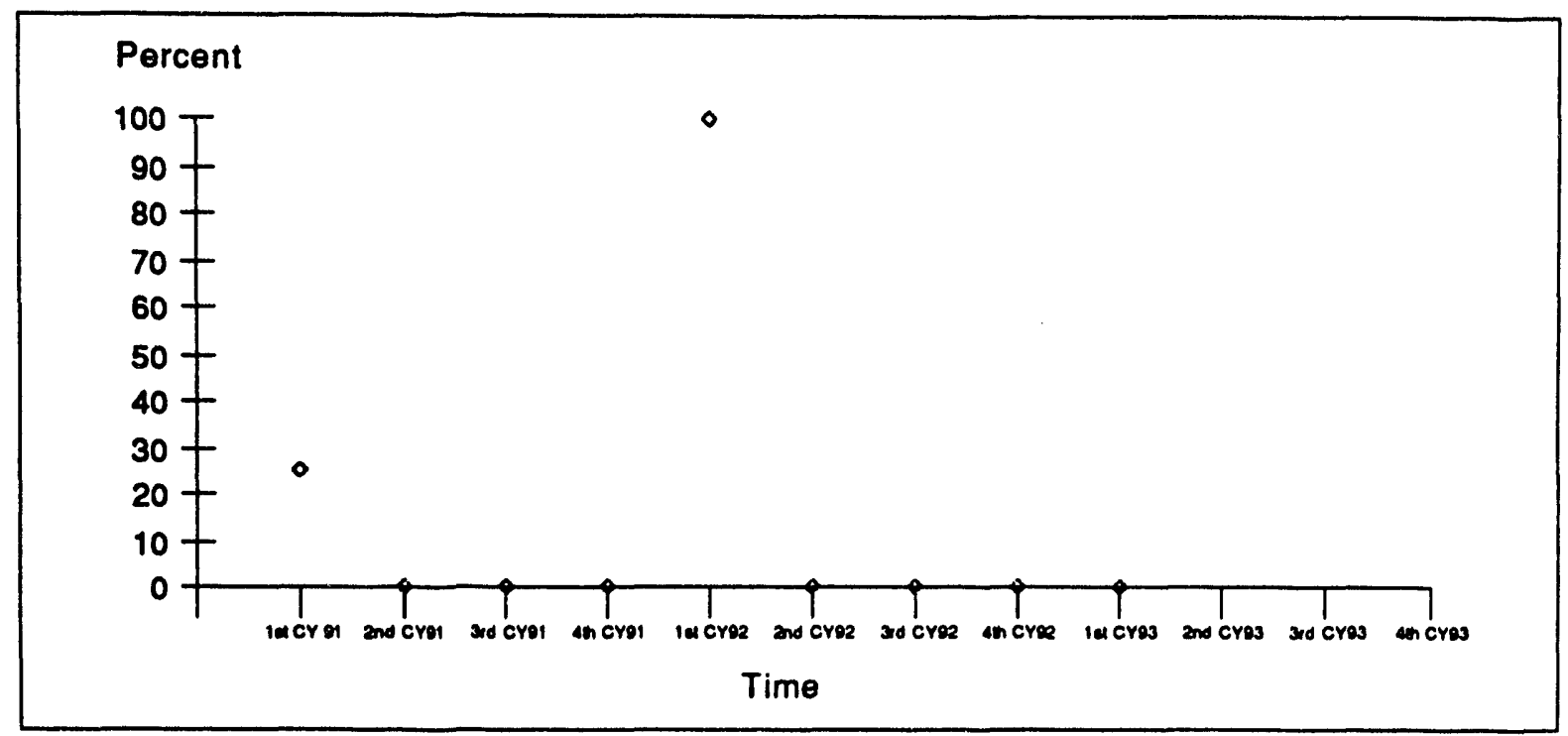

- During the first quarter of 1993 at the TRA Hot Cells, none of the scheduled PM items were not completed within the originally scheduled interval.

\subsection{Occurrence Beponts With Open Correctlve Actlons}

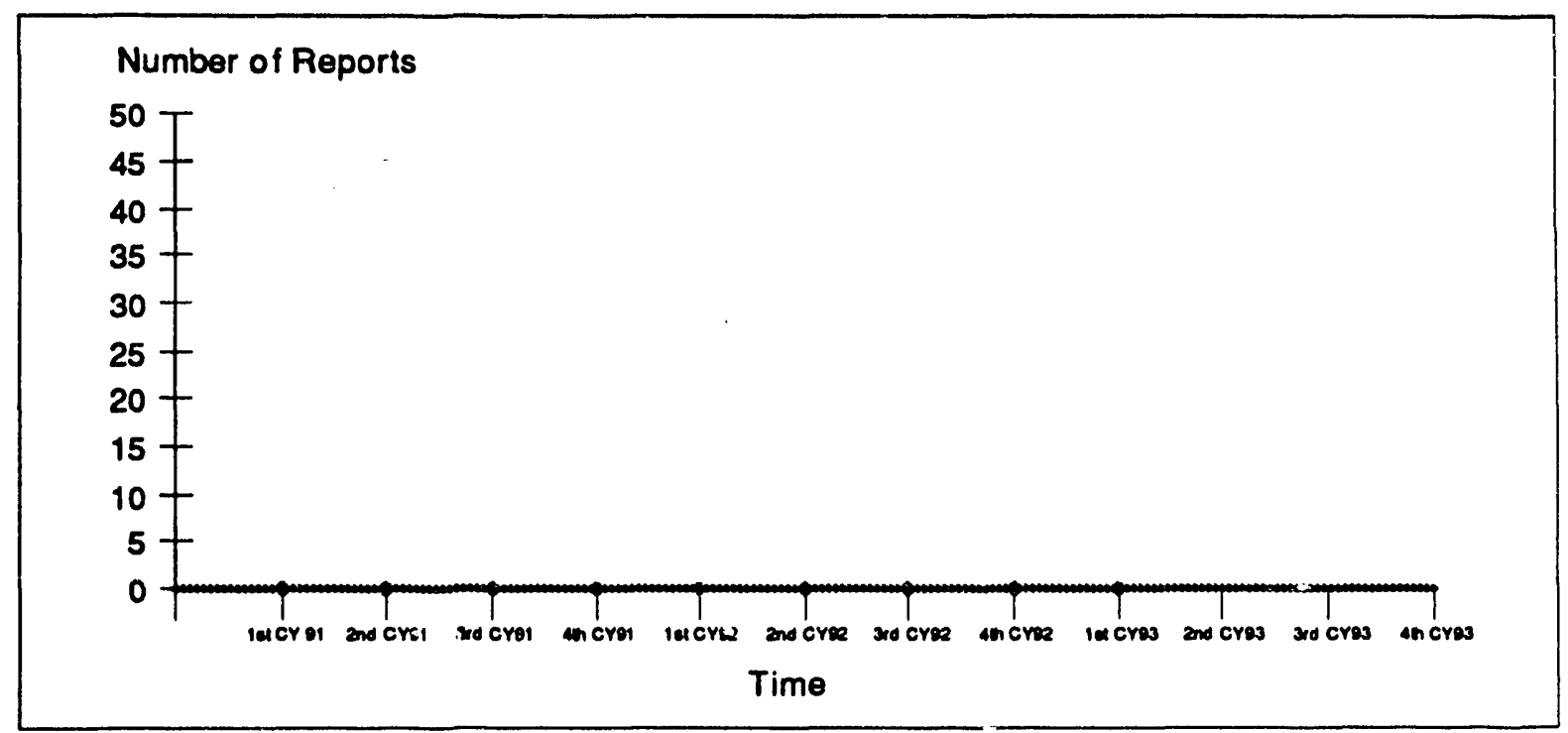

- At the close of the first quarter, no Final Occurrence Reports (ORs) had open corrective actions at the TRA Hot Colls. 


\section{Appendix F - DATA SUMMARY}

Tabulated quarterly data summaries are presented in the following section for EG\&G Idaho, Inc. Performance indicator data is provided for all nine quarters of the PI Program. A summary of root cause data is presented for the current quarter only.

These tables, represent the most current data from the EG\&G facilities and contractor and are used as the basis for the charts and text accompanying this report. 


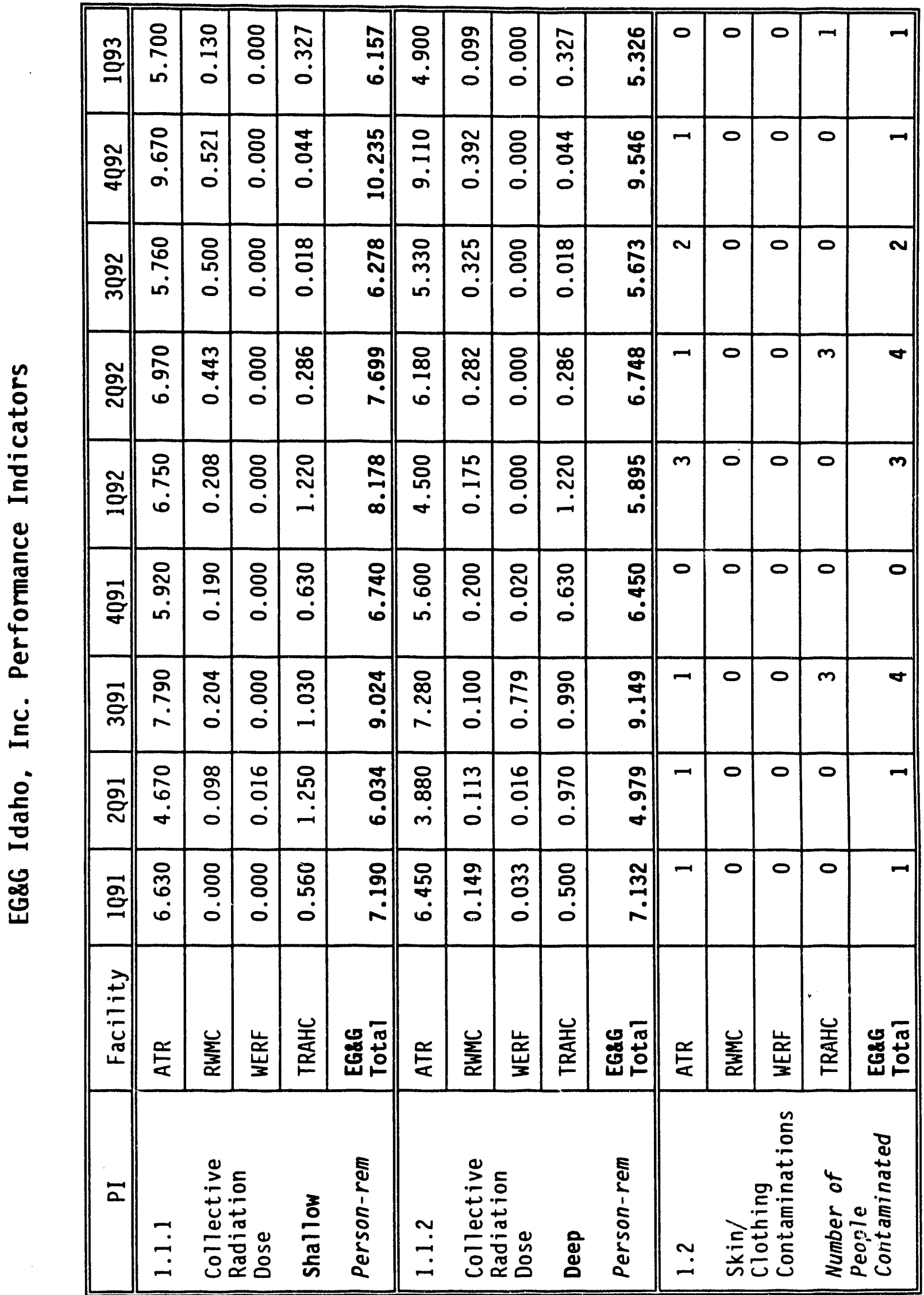




\begin{tabular}{|c|c|c|c|c|c|c|c|c|c|c|c|c|c|}
\hline פ్ & 0 & 0 & 0 & 0 & 0 & 0 & 0 & 0 & 0 & $\stackrel{\infty}{-\infty}$ & & 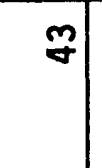 & 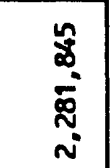 \\
\hline $\begin{array}{l}\tilde{y} \\
\text { gे } \\
\text { d }\end{array}$ & 0 & 0 & 0 & 이 & 이 & 0 & 0 & 0 & 이 & 9 & & $\mathscr{8}$ & $\begin{array}{l}\text { Rू } \\
\stackrel{N}{N} \\
\text { N }\end{array}$ \\
\hline ฐ్ & 0 & 0 & 0 & 0 & 0 & 0 & 0 & 0 & 0 & $\vec{N}$ & & 8 & 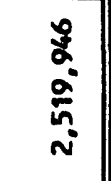 \\
\hline ฉั & -1 & 0 & -1 & 0 & $\sim$ & 0 & 0 & 0 & 0 & $\approx$ & & $q$ & 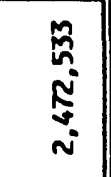 \\
\hline ฮั & 0 & 0 & 0 & 이 & 0 & 0 & 0 & 0 & 0 & 9 & & $\stackrel{\infty}{\infty}$ & 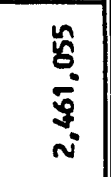 \\
\hline $\bar{a}$ & 0 & 0 & 010 & 0 & 이 & 0 & 0 & 0 & 0 & $\vec{m}$ & & F & 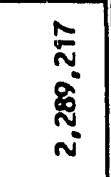 \\
\hline$\overline{\mathrm{a}}$ & 0 & -1 & 0 & 0 & -1 & 0 & 0 & 0 & 0 & a) & & $\stackrel{m}{m}$ & 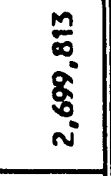 \\
\hline$\overline{\check{\nu}}$ & 0 & 0 & -1 & 0 & -1 & 0 & 0 & 0 & 0 & $\stackrel{\infty}{\mathbf{N}}$ & & $\mathcal{F}$ & 怘 \\
\hline 흥 & 0 & 0 & 0 & 0 & 0 & 0 & 0 & 0 & 0 & 이 & & $\stackrel{\infty}{\infty}$ & 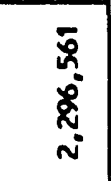 \\
\hline 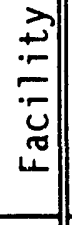 & $\underset{\mathbb{L}}{\mathbb{\alpha}}$ & 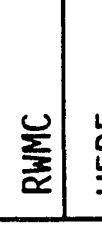 & 薆 & 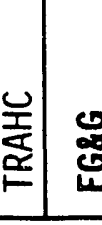 & 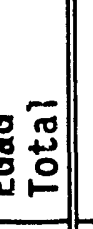 & 品 & $\sum_{x}^{U}$ & 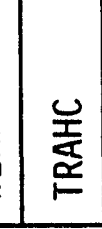 & 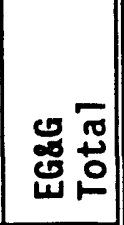 & 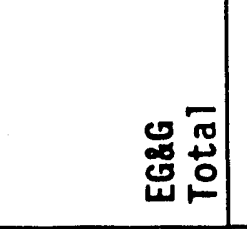 & & 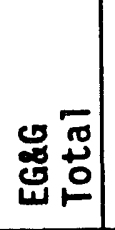 & \begin{tabular}{l}
0 \\
\multirow{0}{0}{}
\end{tabular} \\
\hline $\bar{a}$ & $\stackrel{m}{-}$ & 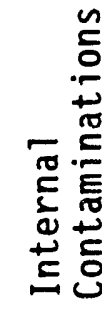 & 竞 & 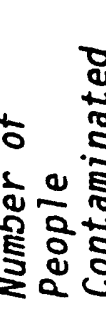 & D. & $\begin{array}{l}0 \\
\dot{0}\end{array}$ & 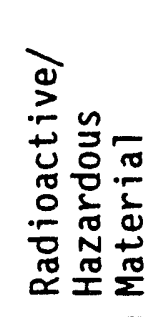 & 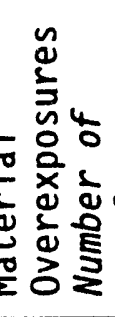 & 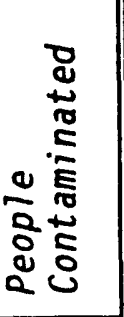 & 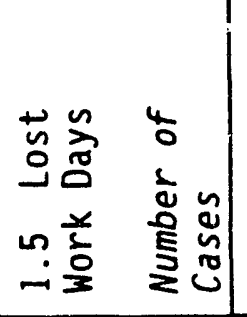 & 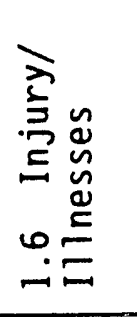 & 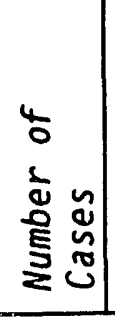 & 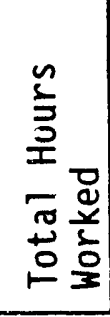 \\
\hline
\end{tabular}




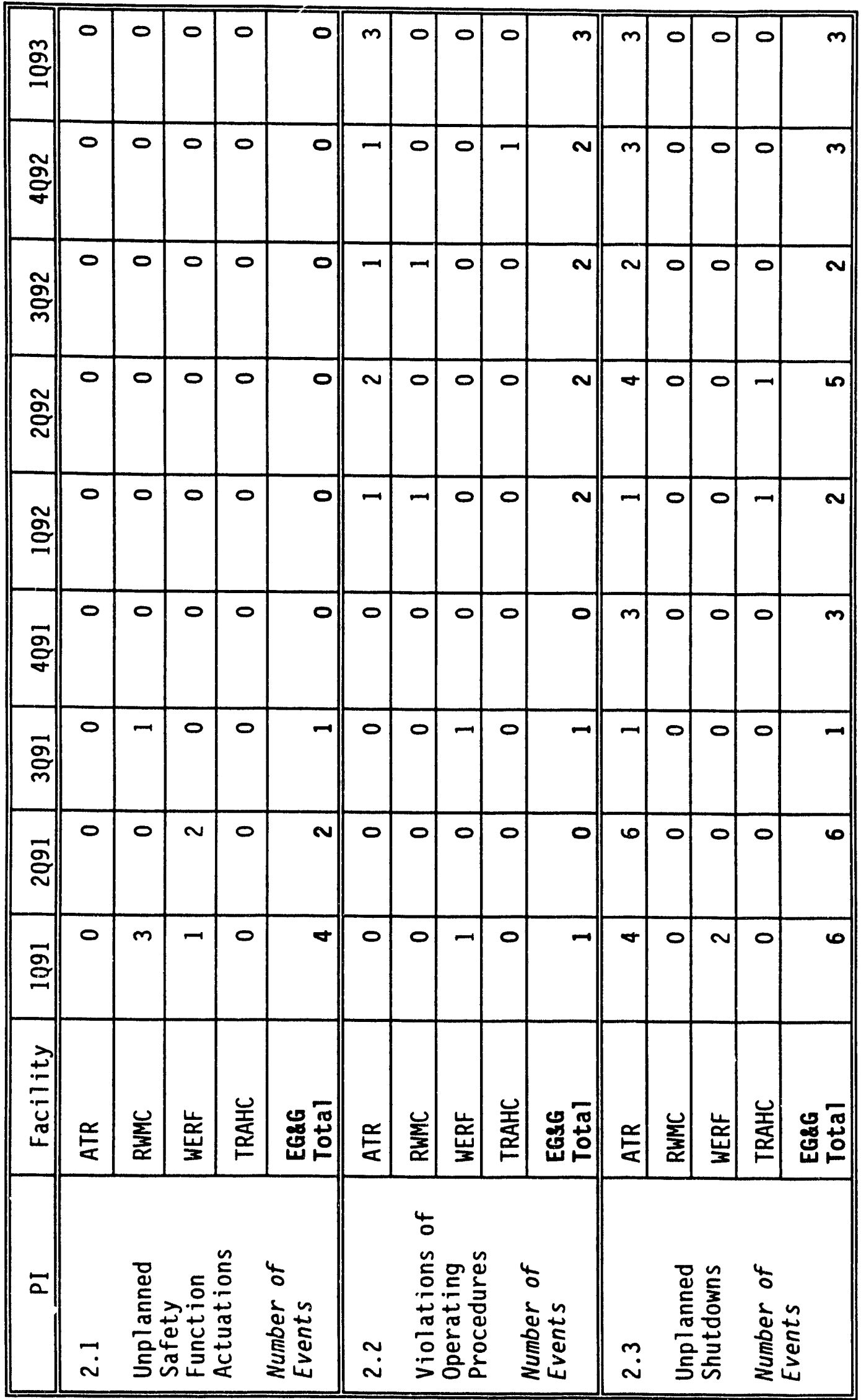




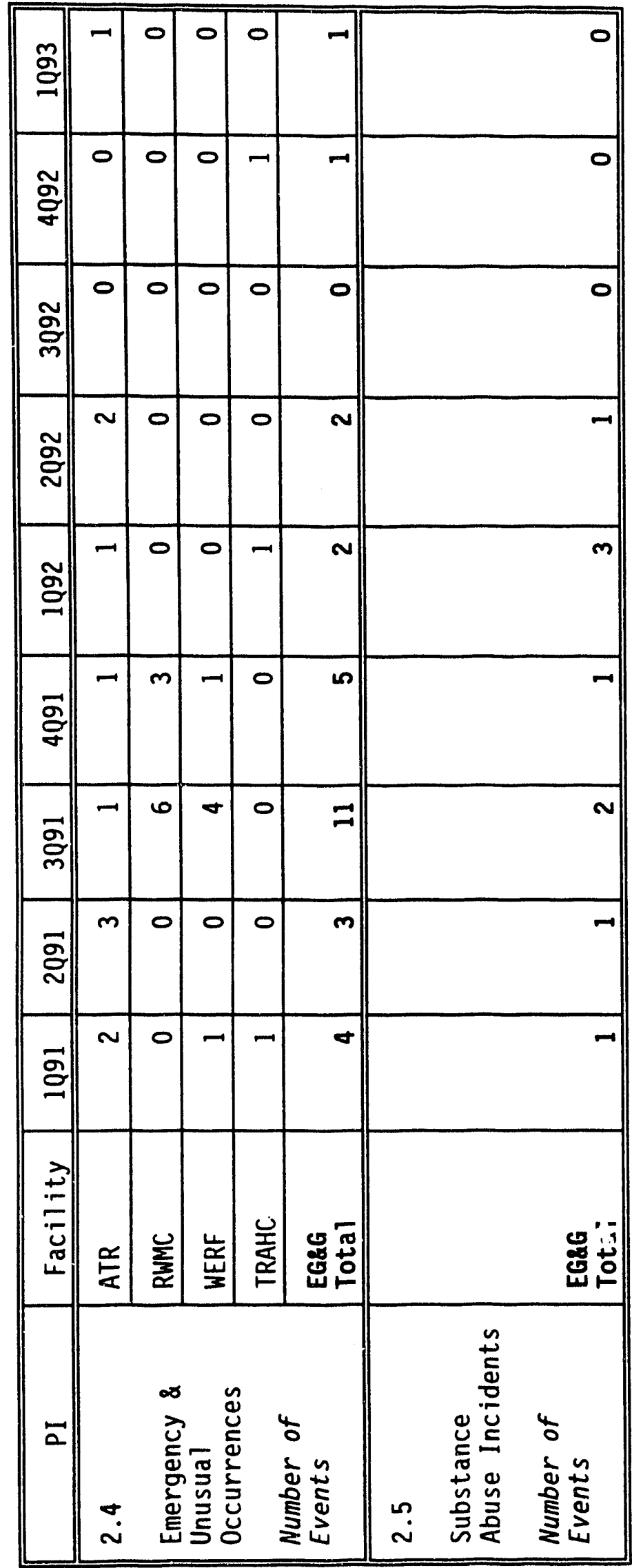




\begin{tabular}{|c|c|c|c|c|c|c|c|c|c|c|c|c|c|c|c|c|}
\hline ğ & $\begin{array}{l}0 \\
\dot{0} \\
\dot{\infty}\end{array}$ & $\begin{array}{l}0 \\
0\end{array}$ & $\begin{array}{l}0 \\
0\end{array}$ & 0 & $\begin{array}{l}0 \\
\dot{0} \\
\mathscr{0} \\
\infty\end{array}$ & ஸ் & $\begin{array}{l}0 \\
0\end{array}$ & $\begin{array}{l}0 \\
0\end{array}$ & $\begin{array}{l}0 \\
0\end{array}$ & $\stackrel{\sim}{\stackrel{N}{N}}$ & 0 & 0 & 0 & 0 & & 0 \\
\hline ๙ั. & $\begin{array}{l}\tilde{m} \\
\tilde{m}\end{array}$ & $\begin{array}{l}0 \\
0\end{array}$ & $\begin{array}{l}0 \\
0\end{array}$ & Oئ & $\begin{array}{l}n \\
\stackrel{n}{\tilde{m}}\end{array}$ & $\begin{array}{l}\mathscr{D} \\
\infty \\
\infty \\
\infty\end{array}$ & $\begin{array}{l}8 \\
0 \\
0\end{array}$ & $\begin{array}{l}8 \\
\circ \\
0\end{array}$ & $\begin{array}{l}8 \\
\\
0\end{array}$ & $\begin{array}{l}\mathscr{0} \\
\infty \\
\infty \\
\infty \\
0\end{array}$ & 0 & 0 & 0 & 0 & & 0 \\
\hline 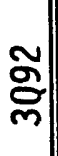 & $\begin{array}{l}+ \\
\dot{\dot{W}} \\
\dot{\sigma}\end{array}$ & $\begin{array}{l}0 \\
0\end{array}$ & $\begin{array}{l}0 \\
0\end{array}$ & مُ & $\begin{array}{l}\dot{0} \\
\dot{0} \\
\dot{g}\end{array}$ & $\begin{array}{l}n \\
\stackrel{n}{n} \\
\dot{m}\end{array}$ & $\begin{array}{l}8 \\
\\
0\end{array}$ & $\begin{array}{l}8 \\
\circ \\
0\end{array}$ & $\begin{array}{l}\text { 이 } \\
0\end{array}$ & 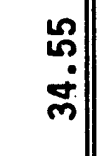 & 0 & 0 & 0 & 0 & & 0 \\
\hline ๙̃ & \begin{tabular}{l}
$\sim$ \\
\multirow{\leftarrow}{\sigma}{} \\
ஸे
\end{tabular} & $\begin{array}{l}0 \\
0\end{array}$ & $\begin{array}{l}0 \\
0\end{array}$ & 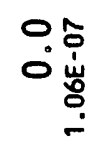 & $\begin{array}{l}\sim \\
\dot{5} \\
\text { مे }\end{array}$ & $\begin{array}{l}\stackrel{m}{m} \\
\dot{\sigma}\end{array}$ & $\begin{array}{l}8 \\
\\
0\end{array}$ & $\begin{array}{l}\text { 영 } \\
\dot{0}\end{array}$ & $\begin{array}{l}8 \\
8 \\
0\end{array}$ & $\begin{array}{l}0 \\
\text { p. } \\
\dot{q}\end{array}$ & 0 & 0 & 0 & 0 & & 0 \\
\hline ฐ̃ & 뭉 & : & $\begin{array}{l}0 \\
0\end{array}$ & 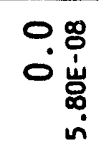 & $\begin{array}{l}- \\
\dot{g} \\
\stackrel{\sigma}{0}\end{array}$ & $\begin{array}{l}8 \\
8 \\
8\end{array}$ & $\begin{array}{l}\text { 임 } \\
\circ\end{array}$ & $\begin{array}{l}\circ \\
\circ \\
0\end{array}$ & $\begin{array}{l}8 \\
\\
0\end{array}$ & $\begin{array}{l}8 \\
8 \\
8\end{array}$ & 0 & 0 & 0 & 0 & & 0 \\
\hline के & $\begin{array}{l}0 \\
\dot{N} \\
\end{array}$ & $\begin{array}{l}0 \\
0\end{array}$ & $\stackrel{0}{0}$ & 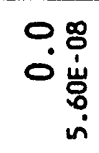 & $\begin{array}{l}0 \\
\dot{0} \\
\end{array}$ & $\begin{array}{l}8 \\
\infty \\
\dot{\sigma}\end{array}$ & $\begin{array}{l}8 \\
\\
\circ\end{array}$ & $\begin{array}{l}8 \\
0 \\
0\end{array}$ & $\begin{array}{l}8 \\
0 \\
\circ\end{array}$ & $\begin{array}{l}\dot{8} \\
\dot{0} \\
\dot{\sigma}\end{array}$ & 0 & 0 & 0 & 0 & & 0 \\
\hline $\bar{g}$ & $\begin{array}{l}\tilde{\sigma} \\
\dot{\sigma}\end{array}$ & $\stackrel{0}{0}$ & $\stackrel{0}{\circ}$ & نَّ & $\begin{array}{l}- \\
\dot{g} \\
\dot{f}\end{array}$ & $\begin{array}{l}\text { 口̆ } \\
\dot{0}\end{array}$ & $\begin{array}{l}\text { 영 } \\
0\end{array}$ & $\begin{array}{l}\text { 용 } \\
0\end{array}$ & $\begin{array}{l}\text { 영 } \\
\dot{0}\end{array}$ & $\begin{array}{l}\text { \%ి } \\
\dot{0}\end{array}$ & 0 & 0 & 0 & 0 & & 0 \\
\hline ్ㅗㅇ & $\begin{array}{l}m \\
\frac{m}{\sigma}\end{array}$ & $\stackrel{0}{0}$ & . & $\begin{array}{r}0.8 \\
0 \\
0 \\
\stackrel{+}{4} \\
0 \\
0\end{array}$ & $\begin{array}{l}m \\
\infty \\
\infty \\
\sigma\end{array}$ & $\begin{array}{l}\boldsymbol{\Omega} \\
\dot{\boldsymbol{m}} \\
\dot{m}\end{array}$ & $\begin{array}{l}8 \\
\circ \\
0\end{array}$ & $\begin{array}{l}8 \\
0 \\
0\end{array}$ & $\begin{array}{l}8 \\
\\
0\end{array}$ & $\begin{array}{l}n \\
0 \\
\dot{m}\end{array}$ & 0 & 0 & 0 & 0 & & 0 \\
\hline 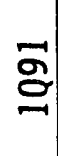 & $\begin{array}{l}\text { ஜ் } \\
\text { ஸू }\end{array}$ & $\begin{array}{l}0 \\
0\end{array}$ & $\stackrel{0}{0}$ & $\begin{array}{r}0.8 \\
0 \\
0 \\
\stackrel{4}{0} \\
0 \\
0\end{array}$ & $\begin{array}{l}0 \\
\text { ஸे. } \\
\text { o. }\end{array}$ & $\begin{array}{l}8 \\
g \\
g\end{array}$ & $\begin{array}{l}8 \\
0 \\
0\end{array}$ & $\begin{array}{l}8 \\
0 \\
0\end{array}$ & $\begin{array}{l}8 \\
\\
0\end{array}$ & $\begin{array}{l}8 \\
8 \\
g \\
8\end{array}$ & 0 & 0 & 0 & 0 & & 0 \\
\hline 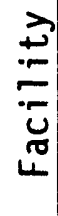 & $\underset{\leftarrow}{\mathbb{E}}$ & $\frac{\sum}{\frac{\sum}{z}}$ & $\begin{array}{l}\text { 岁 } \\
\frac{4}{3}\end{array}$ & ㄴㅗㅗ & $\begin{array}{l}0 \\
0 \\
\mathbb{8}\end{array}$ & $\underset{\mathbb{E}}{\stackrel{a}{E}}$ & $\sum_{\bar{x}}^{U}$ & $\begin{array}{l}\frac{\mathrm{w}}{\sigma} \\
\frac{\mathrm{w}}{\underline{I}}\end{array}$ & 产 & 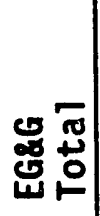 & 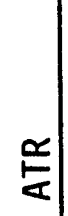 & $\sum_{\bar{x}}^{\stackrel{U}{x}}$ & 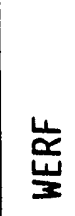 & 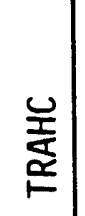 & & 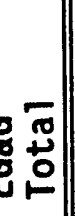 \\
\hline$\vec{a}$ & $\dot{\vec{m}}$ & $\begin{array}{l}\frac{0}{0} \\
0 \\
0 \\
0 \\
0 \\
0\end{array}$ & 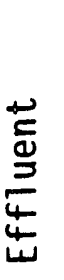 & 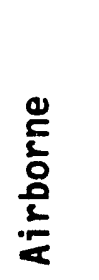 & $\stackrel{\mathscr{c}}{\mathfrak{\vdots}}$ & $\stackrel{\sim}{\ddot{m}}$ & 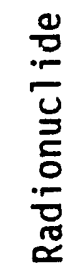 & 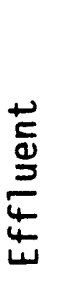 & $\frac{0}{\frac{0}{3}}$ & $\frac{n}{5}$ & $\ddot{\sim}$ & 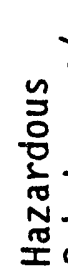 & 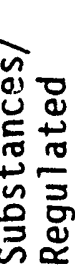 & 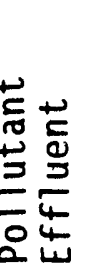 & $\begin{array}{l}\stackrel{0}{2} \\
\frac{2}{\delta} \\
\frac{1}{2} \\
\frac{2}{\alpha}\end{array}$ & 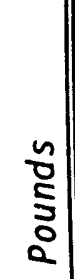 \\
\hline
\end{tabular}




\begin{tabular}{|c|c|c|c|c|c|c|c|c|c|c|c|c|c|c|c|c|c|}
\hline $\begin{array}{c}m \\
\mathscr{g}\end{array}$ & 0 & 0 & 0 & 0 & & 0 & 0 & 0 & 0 & 0 & 0 & $\stackrel{\dot{D}}{\sim}$ & $\stackrel{\stackrel{0}{\dddot{n}}}{ }$ & 官 & $\underset{\sim}{\stackrel{0}{N}}$ & & $\stackrel{0}{\dot{R}}$ \\
\hline $\begin{array}{l}\widetilde{\gamma} \\
\text { वे } \\
\text { | }\end{array}$ & 0 & 0 & 0 & 0 & & 0 & 0 & 0 & 0 & 0 & 0 & $\begin{array}{l}0 \\
0 \\
0 \\
\vdots \\
m\end{array}$ & $\stackrel{0}{\stackrel{i}{N}}$ & $\stackrel{0}{\check{n}}$ & $\begin{array}{l}0 \\
\stackrel{d}{d} \\
\stackrel{\sim}{~}\end{array}$ & & 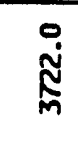 \\
\hline 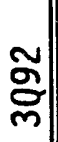 & 0 & 0 & 0 & 0 & & 0 & 0 & 0 & 0 & 0 & 0 & $\stackrel{\circ}{\stackrel{0}{\sim}}$ & $\stackrel{n}{\check{n}}$ & $\underset{\sim}{\stackrel{0}{\sim}}$ & $\begin{array}{l}0 \\
\dot{\sim}\end{array}$ & & $\hat{\tilde{R}}$ \\
\hline §ั & 0 & $\infty$ & 0 & 0 & & $\infty$ & 0 & $\sim$ & 0 & 0 & $N$ & $\stackrel{0}{\circ}$ & : & $\stackrel{0}{\frac{1}{\infty}}$ & iे & & $\frac{i}{N}$ \\
\hline ป̊ & 0 & 0 & 0 & 0 & & 0 & 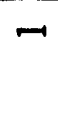 & 0 & 0 & 0 & $\rightarrow$ & $\stackrel{\infty}{\stackrel{\infty}{\cong}}$ & i. & $\dot{\tilde{N}}$ & $\begin{array}{l}\circ \\
\dot{\infty}\end{array}$ & & ڤ̊ \\
\hline $\begin{array}{l}\vec{g} \\
\dot{\sigma}\end{array}$ & 0 & 0 & 0 & 0 & & 0 & 0 & 0 & 0 & 0 & 0 & $\begin{array}{l}\infty \\
\dot{0} \\
\stackrel{0}{\not}\end{array}$ & $\frac{\dot{d}}{\mathbf{N}}$ & $\begin{array}{l}0 \\
\stackrel{\dot{\omega}}{\sim}\end{array}$ & $\begin{array}{l}0 \\
\stackrel{\sim}{\sim}\end{array}$ & & $\stackrel{\infty}{\stackrel{\infty}{*}}$ \\
\hline$\vec{\sigma}$ & 0 & 0 & 0 & 0 & & 0 & 0 & 0 & $\rightarrow$ & 0 & $\rightarrow$ & ه̊․ㅇ & 吕 & 竨 & i̊ & & ڤั̀ \\
\hline $\begin{array}{c}\bar{\sigma} \\
\stackrel{\sim}{\sim}\end{array}$ & 0 & 0 & 0 & 0 & & 0 & 0 & 0 & 0 & 0 & 0 & 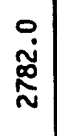 & $\begin{array}{l}0 \\
\dot{N} \\
\text { n }\end{array}$ & $\stackrel{\circ}{\dot{j}}$ & 品 & & 总 \\
\hline $\bar{\sigma}$ & 0 & 0 & 0 & 0 & & 0 & 0 & 0 & 0 & 0 & 0 & $\begin{array}{l}\infty \\
\ddot{\infty} \\
\ddot{\infty}\end{array}$ & $\begin{array}{l}\stackrel{0}{\dot{\omega}} \\
\stackrel{0}{N}\end{array}$ & $\begin{array}{l}\ddot{0} \\
\text { in }\end{array}$ & 品 & & $\stackrel{\infty}{\stackrel{\infty}{\alpha}}$ \\
\hline 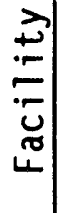 & $\underset{\mathbb{E}}{\mathbb{E}}$ & $\sum_{\frac{1}{x}}^{\frac{U}{x}}$ & $\begin{array}{l}\text { 宸 } \\
\end{array}$ & 옹 & & 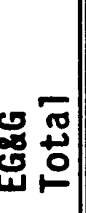 & $\underset{\leftarrow}{\stackrel{\alpha}{\leftarrow}}$ & $\underset{\frac{\sum}{x}}{\frac{\omega}{x}}$ & 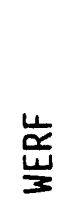 & 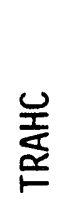 & 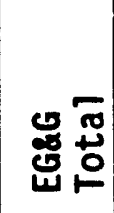 & $\underset{\frac{x}{}}{\mathbb{\alpha}}$ & $\sum_{\frac{2}{\alpha}}^{u}$ & $\begin{array}{l}\frac{u}{\mathbf{z}} \\
\frac{u}{3}\end{array}$ & 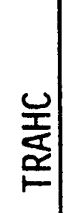 & & 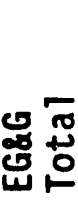 \\
\hline$\vec{a}$ & $\stackrel{\sim}{\sim}$ & 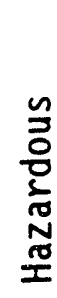 & 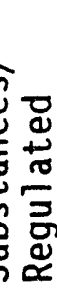 & 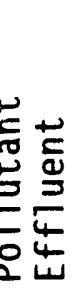 & $\begin{array}{l}\frac{\mathscr{2}}{2} \\
\frac{8}{8} \\
\frac{8}{2} \\
\frac{2}{2}\end{array}$ & $\begin{array}{l}\mathfrak{v} \\
\stackrel{5}{5} \\
0\end{array}$ & $\dot{m}$ & 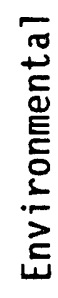 & & & 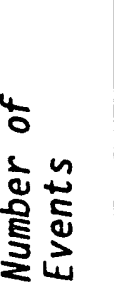 & $\begin{array}{l}\dot{\nabla} \\
\dot{m}\end{array}$ & $\begin{array}{l}3 \\
0 \\
0 \\
i \\
0 \\
0\end{array}$ & 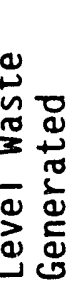 & & 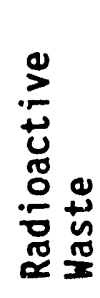 & 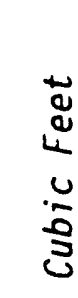 \\
\hline
\end{tabular}




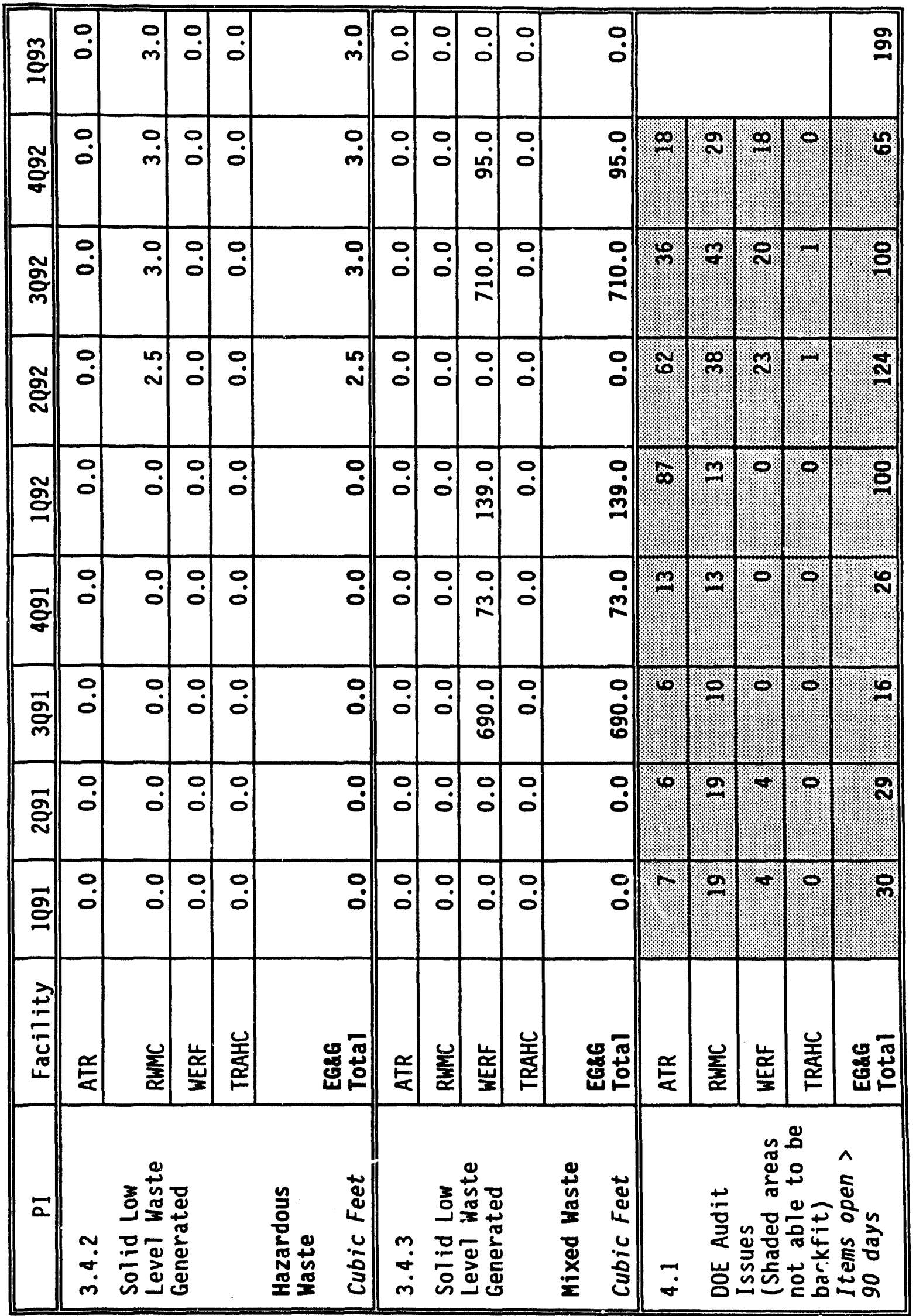




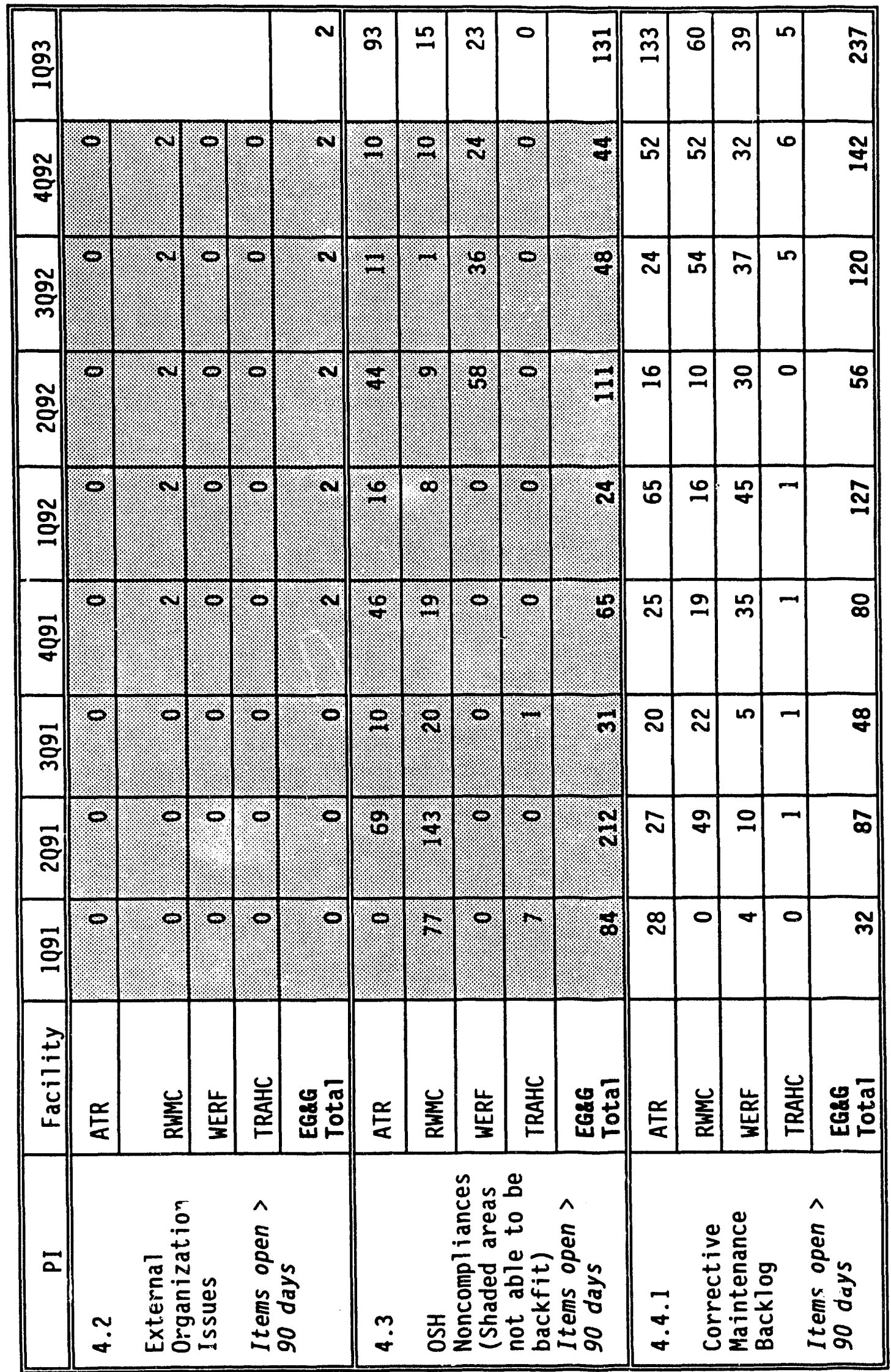




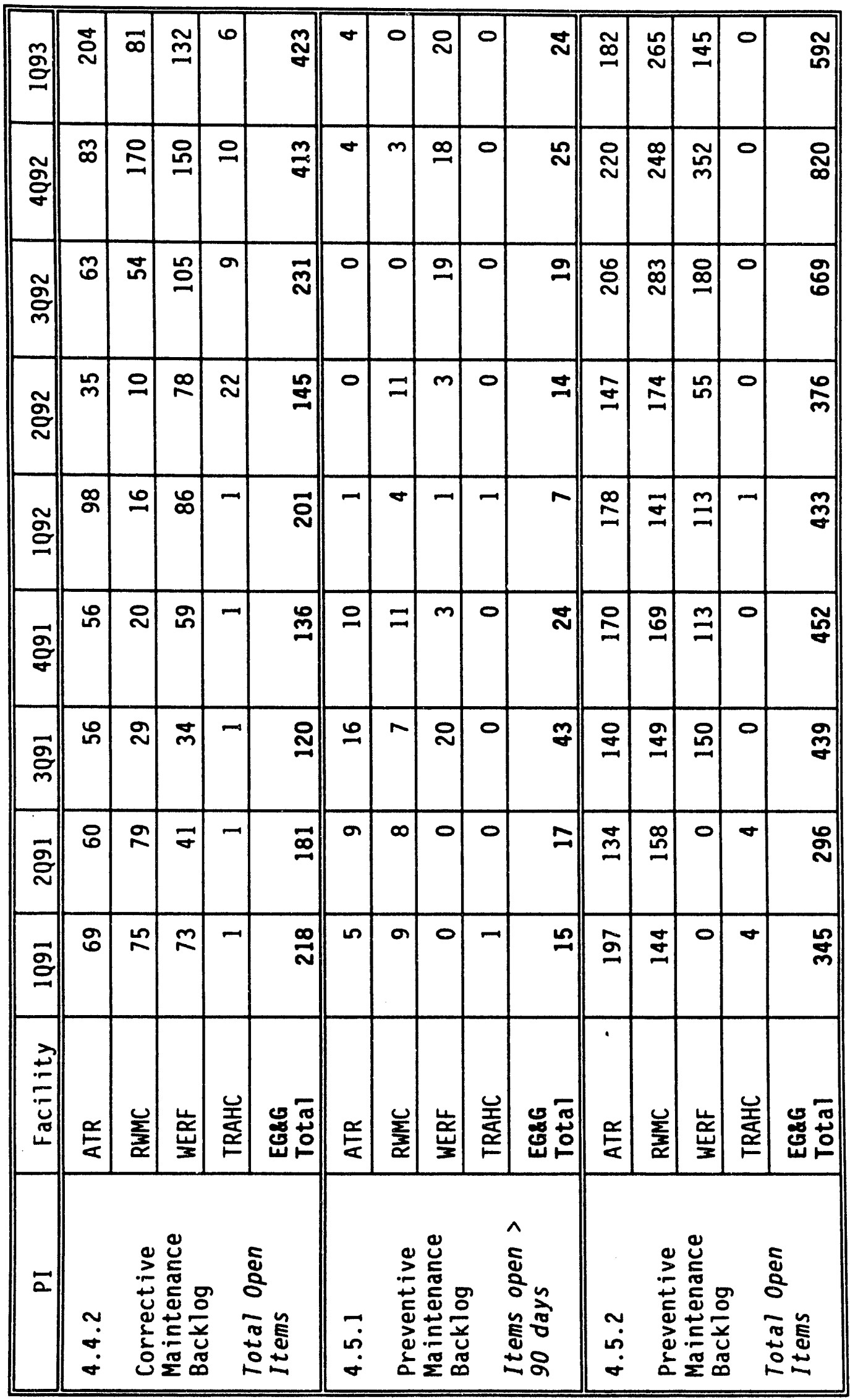




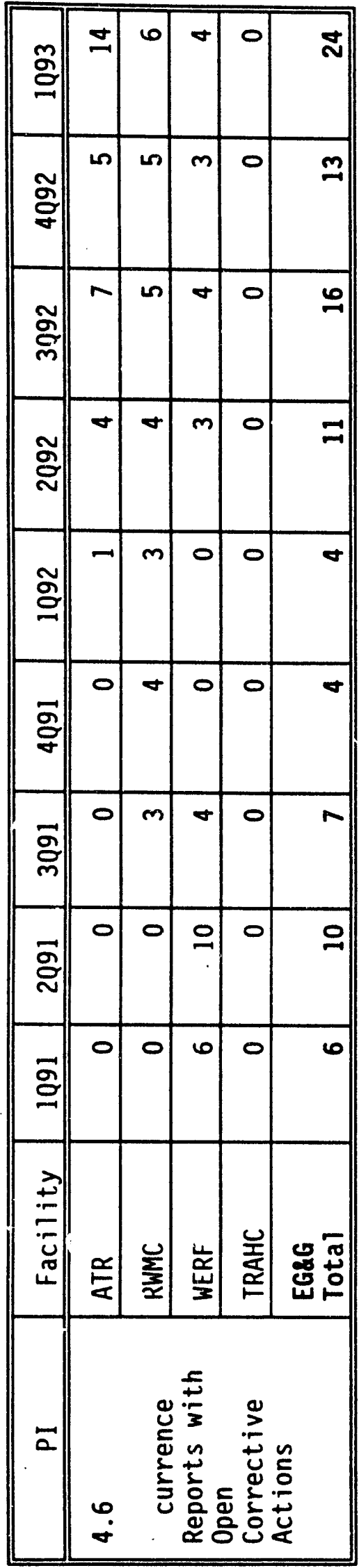




\section{CURRENT QUARTER ROOT CAUSE DATA SUMMARY}

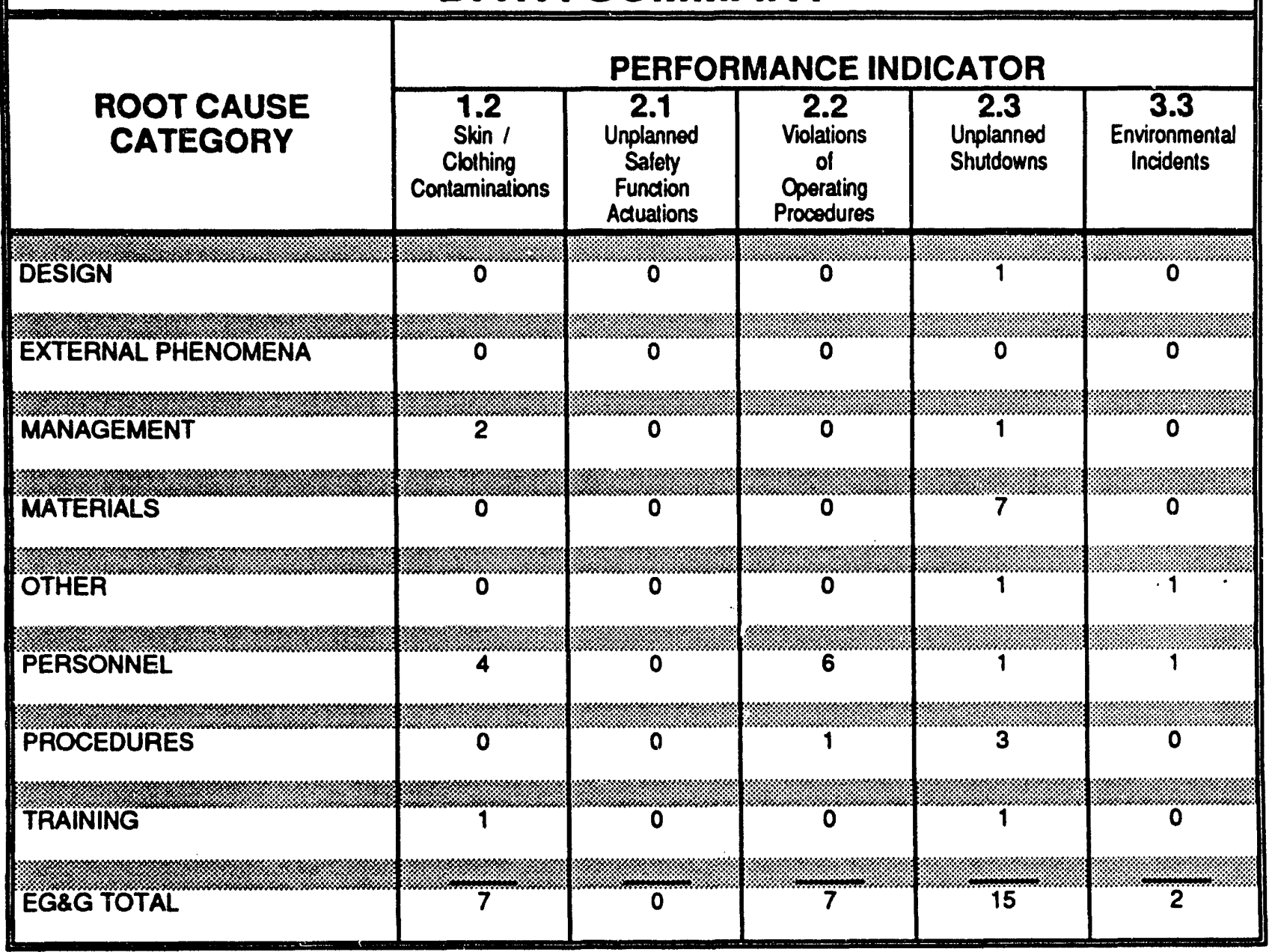




\section{Appendix G - Performance Indicator Definitions}

This appendix provides descriptions of the 26 performance indicators of DOE facility performance. Comments on these definitions are anticipated from DOE contractors, Operations Offices and Headquarters organizations. Based on the resolution of these comments, the performance indicator definitions may be revised for future reports. The performance indicators are identified consistent with the numbering in DOE-STD-1048-92.

\subsection{PERSONNEL SAFETY}

\subsection{Collective Radiation Dose}

Purpose: The purpose of this indicator is to measure the effectiveness of the facility radiation control program in maintaining facility personnel radiation exposures as low as reasonably achievable (ALARA).

Definilien: The total external whole-body dose (deep and shallow) received by all facility personnel (including subcontractors and visitors) as measured by the primary dosimeter, i.e., thermoluminescent dosimeter (TLD), or film badge. Exposure measured by direct reading dosimeters should be included only for those periods or situations when more accurate data are not available.

Netes: Data for this indicator are mainly collected quarterly by contractor. For reporting under this indicator, the data should be collected on a facility basis. It is recognized that the collective radiation dose for certain personnel (maintenance, health physicists, construction, etc.), due to their site-wide services, may be difficult to identify as resulting from exposure at a given facility. How these personnel are handled in each specific facility case should be discussed in written descriptive statements that are provided with the data.

Data Needed: PI 1.1.1 Shallow dose.

PI 1.1.2 Deep dose.

Units: Person-rem.

\subsection{Skin/Clothing Contaminatlens}

Purpese: The purpose of this indicator is to monitor progress in controlling radioactive contamination as a measure of the effectiveness of radiological work practices. A low number of contaminations indicates good radiological work practices, minimum contamination in areas intended to be free of contamination, and/or effective precautions for work in contaminated areas. This indicator is valuable for identifying adverse trends so that corrective actions can be taken.

Definttion: The total number of confirmed skin and personal clothing contaminations (reportable under DOE order 5000.3B, Attachment 1, Group 4.B all) for all facility personnel, including subcontractors and visitors. Skin or clothing contamination due to radioactive noble gases or naturally occurring radon gas will not be included.

Notes: The intent of this $\mathrm{PI}$ is to count the number of personnel contaminated, not the number of related occurrence reports. It is emphasized that, since one occurrence report can involve more than one PI event, care must be taken when using the Occurrence Report Processing System as a source for PI data. Individual occurrence reports must be reviewed to determine the PIs involved.

Date Needed: PI 1.2 Number of personnel contaminated. 


\subsection{Internal Contaminations}

Purpese: The purpose of this indicator is to monitor the effectiveness of radiological control programs to limit the internal intake and deposit of radiological materials by facility personnel.

Definitlon: The total number of intakes of radioactive material (positive bioassays reportable under DOE Order 5000.3B Attachment 1, Group 4-C all) confirmed during the reporting period for all facility personnel, including subcontractors and visitors.

Notes: Verification of contamination of an indiviaual through multiple bioassays will be reported as 1 personnel contamination. The intent of this $\mathrm{PI}$ is to count the number of personnel contaminated, not the number of related occurrence reports. It is emphasized that, since one occurrence report can involve more than one PI event, care must be taken when using the Occurrence Report Processing System as a source for PI data. Individual occurrence reports must be reviewed to determine the Pls involved.

Data_Neededi PI 1.3 Number of personnel contaminated.

\subsection{Radloactive or Hazardous Material Overexposures}

Rurpose: The purpose of this indicator is to measure the overall effectiveness of the facility radiation and hazardous material control programs that are established to ensure the prevention of overexposures.

Definlition: The number of personnel exposed to radioactive or hazardous materials in excess of limits established in DOE Orders (reportable occurrences per DOE order 5000.3B Attachment 1. Group $3 C$ and $4 A$, all). Includes all facility personnel, including subcontractors and visitors.

Netsis: The intent of this PI is to count the number of personnel overexposed, not the number of related ciccurrence reports. It is emphasized that, since one occurrence report can involve more than one PI event, care must be taken when using the Occurrence Report Processing System as a source for PI data. Individual occurrence reports must be reviewed to determine the PIs involved.

Dara Needed: PI 1.4 Number of personnel exposed. 


\subsection{Lost Work Day Case Rate}

Purpose: The purpose of this indicator is to measure the progress in improving occupational safety and health performance for contractor personnel. This indicator measures the number of accidents that are serious enough to require time off from work.

Definitien: Number of lost work day cases per 200,000 hours worked (100 person years). Subcontractors and visitors will be excluded.

Notes: Report case in the period that it is confirmed as OSH reportable (similar to reporting internal contaminations based on date of confirmation).

Subcontractors and visitors are excluded because it is consistent with OSH and it would be impossible to determine the hours worked contribution. Accidents and illnesses will be counted against the permanent assignment location rather than where the accident occurred because of the difficulty in determining the hours worked contribution. The facility is responsible for the employee independent of the temporary work location.

This PI is intended to report only lost work day cases and will not include restricted work cases.

Rate $=(200,000$ hours $X$ number of cases $) /$ (total hours worked)

Data Needed: PI 1.5.1 Number of cases.

PI 1.5.2 Total hours worked.

Contractor total.

\subsection{Recordable Iniury/liness Rate}

Purpose: The purpose of this indicator is to measure the progress in improving the occupational safety and health for contractor personnel. By measuring all work-related injuries and illnesses meeting OSH Standards, this indicator measures all instances where work restrictions occur.

Definition: Number of personnel injury or illness cases resulting from on-the-job activities recordable in accordance with OSH standards, per 200,000 person-hours worked (100 personyears). Subcontractors and visitors will be excluded.

Notes: Report case in the period that it is confirmed as OSHA reportable (similar to reporting internal contaminations based on date of confirmation:).

Subcontractors and visitors are excluded because it is consistent with OSHA and it would be impossible to determine the hours worked contribution. Accidents and illnesses will be counted against the permanent assignment location rather than where the accident occurred because of the difficulty in determining the hours worked contribution. The facility is responsible for the employee independent of the temporary work location.

Data Needed: $\quad$ PI 1.6.1 Number of cases

[The total hours worked is reported under PI 1.5.2]

Contractor total. 


\subsection{OPERATIONAL INCIDENTS}

\subsection{Unolanned Safety Function Actuations}

Purpose: The purpose of this indicator is to monitor progress in reducing the number of instances of significant abnormal facility conditions, requiring the actuation of facility safety functions (equipment/systems). In addition, this indicator monitors the unnecessary exercising of facility safety functions, due to spurious or inadvertent signals, which could result in those functions not being available when needed. Limiting the number of unplanned safety function actuations indicates that an adequate margin of safety is being maintained.

Definltion: The number of unplanned actuations of any safety function or facility safety systems that occur when an actuation setpoint for a safety function is reached or when a spurious or inadvertent signal is generated. Unplanned means that the actuation was not part of a planned test or evolution. Specifically, those incidents reportable under Order $5000.3 b$ Attachment 1 , Group 1-1-(U-(a), ON-(g)).

Notes: Although not included in the definition of safety systems, actuation of a system designed, installed, and operated for the protection of facility or co-located facility workers shall also be included (e.g., fire protection, excluding those in office spaces; radiation monitoring systems such as continuous air monitors; criticality alarm system; etc.). For the purposes of this program, a safety function of system shall be defined to be consistent with the DOE Order 5000.3 definition of "Class A Equipment" - any active or passive safety device/system of any primany environmental monitor.

It is emphasized that, since one occurrence report can involve more than one PI event, care must be taken when using the Occurrence Report Processing System as a source for PI data. Individual occurrence reports must be reviewed to determine the PIs involved.

Data Needed: PI 2.1 Number of events.

\subsection{Violations of Operatino Procedures}

Purpose: The purpose of this indicator is to monitor the adequacy of facility training programs which emphasize compliance with procedures that are intended to ensure safe, healthy, and effective facility operations. This indicator is a measure of the effectiveness of the safety and heatth culture and discipline of the management and staff of the facility.

Definttion: The number of instances where a failure of personnel to follow operating procedures resulted in a reportable occurrence ((per Order DOE 5000.3B Attachment 1, Group 1-F-U, -ON and/or those reportable occurrences whose root, direct, or contributing cause category is Personnel Error, Item C Violation of requirement or procedure).

Netes: It is emphasized that, since one occurrence report can involve more than one PI event, care must be taken when using the Occurrence Report Processing System as a source for PI data. Individual occurrence reports must be reviewed to determine the PIs involved.

Data Needed: PI 2.2 Number of events. 


\subsection{Unolanned Shutdowns}

Purpose: The purpose of this indicator is to measure progress in minimizing unplanned shutdowns that result from equipment failures, personnel errors, and other causes. This indicator reflects the effectiveness of facility programs that support operations and permit the facility to meet its intended mission. These facility programs include, but are not limited to, maintenance, training, and engineering support for correction of design problems. Experience has generally shown that facilities that operate with a high availability rate (i.e., minimal number of unplanned shutdowns are usually well-maintained, are managed and staffed by personnel that are competent and follow good operating practices, and can be expected to have a high margin of safety.

Definltion: The number of unscheduled shutdowns of a facility, process or operation that result in a reportable occurrence (per DOE Order 5000.3B Attachment 1, Group 8, all U and all ON).

Notes: It is emphasized that, since one occurrence report can involve more than one PI event, care must be taken when using the Occurrence Report Processing System as a source for PI data. Individual occurrence reports must be reviewed to determine the Pls involved.

Data Needed: PI 2.3 Number of events.

\subsection{Emergency And Unusual Occurrences}

Purpose: The purpose of this indicator is to provide an overall measure of the frequency of significant problems that arise at a facility. Reporting in accordance with DOE Order 5000.3 provides the details of each occurrence. This indicator provides a measure of the safety culture existing at the facility and the degree of control being maintained over the activities being conducted. Repeated significant problems are an indication of potentially reduced margins of safety for facility operations.

Definltion: The number of Emergency and Unusual Occurrences reported in accordance with DOE Order 5000.3, "Occurrence Reporting and Processing of Operations Information".

Notes: Off-normal occurrences are excluded from this PI.

Data Needed: PI 2.4 Number of events.

\subsection{Substance Abuse Incidents}

Purpose: The purpose of this indicator is to measure the effectiveness of DOE and contractor specific fitness-for-duty programs. Individuals involved with controlled substances contribute to unsafe operating conditions and undermine efforts to accomplish the facility mission.

Definition: The number of reportable occurrences (Order 5000.3B Attachment 1, Group 5-C all) involving personnel use, possession or involvement of/with controlled substances (e.g., drugs, alcohol, etc.).

Notes: It is emphasized that, since one occurrence report can involve more than one PI event, care must be taken when using the Occurrence Report Processing System as a source for PI data. Individual occurrence reports must be reviewed to determine the PIs involved.

Data Needed:

PI 2.5 Number of events.

Contractor total. 


\subsection{ENVIRONMENT}

\subsection{Radionuclide Effluent}

Purpose: The purpose of this indicator is to measure the effectiveness of radiological effluent control programs in place to minimize radionuclide releases to the environment.

Definitten: Separate reporting for total airborne and liquid releases to the environment, as measured at the point of release, for the following radionuclides: plutonium, uranium, noble gases, particulates (including radiocesiums and radiostrontium, and activation products), radioiodine, tritium, and other actinides.

Notes: Some facilities do not directly release effluent to the environment, but transport their effluent to a central treatment facility. The facility shall report 0 (zero) curies released, if the central treatment facility reports under the PI program. The facility shall report the PI as "Not Available", if the central treatment facility does not report under the PI Program. Identification of major constituents in the narrative is consistent with current guidance. Trending individual constituents is recommended at a local level.

Data will be the total released during the quarter.

Data Needed: $\quad$ PI 3.1.1 Airborne Effluent.

PI 3.1.2 Liquid Effluent.

Units: Curies.

\subsection{Hazardous Substance/Regulated Pollutant Effluent}

Puroose: The purpose of this indicator is to measure the effectiveness of the facility programs in place to control and minimize releases to the environment of hazardous substances and regulated pollutants.

Definition: The quantity of hazardous constituent released through "permitted" airborne and liquid non-radioactive effluents during the reporting period. All hazardous substances/regulated pollutants that are listed in permits or otherwise reported to regulators reports are included (e.g., Clear Air Act, NPDES permits, SARA Title III Section 313 reporting requirements).

Netes: This indicator is to reflect the total quantity of hazardous material released and is not limited to only the amount exceeding permitted levels.

Brine, drilling mud, cemient washout, sewage treatment eifluent, non-hazardous constituent of steam emissions and cooling water, and rain water runoff are ex:-nuded.

Some facilities do not directly release effluent to the environment, but transport their effluent to a central treatment facility. The facility shall report 0 (zero) pounds released, if the central treatment facility reports under the PI Program. The facility shall report the PI as "Not Available", if the central treatment facility does not report under the PI Program. Identification of major constituents in the narrative is consistent with current guidance. Trending individual constituents is recommended at a local level.

Date Needed: $\quad$ PI 3.2.1 Airborne Effluent.

PI 3.2.2 Liquid Effluent.

Units: Pounds. 


\subsection{Environmental Incidents}

Purpose: The purpose of this indicator is to measure the effectiveness of the facility programs and controls in place to minimize inadvertent releases of radioactive or hazardous materials to the environment.

Definlition: The number of reportable occurrences (per DOE Order 5000.3B Attachmen: 1, Group 2-A thru -D, all), both on-site and off-site, involving an inadvertent radioactive or hazardsus material spill or release.

Notes: It is emphasized that, since one occurrence report can involve more than one PI event, care must be taken when using the Occurrence Report Processing System as a source for PI data. Individual occurrence reports must be reviewed to determine the PIs involved.

Date Needed: PI 3.3 Number of events

\subsection{Solld Low Level Waste Generated}

Purpese: The purpose of this indicator is to monitor generation of solid low-level radioactive, hazardous and mixed waste. Reducing the volume will decrease storage, transportation, and disposal needs and will decrease the environmental impact of such operations.

Definition: The total volume, in cubic feet, of solid low level radioactive and/or hazardous and/or mixed waste generated during the reported period, separately reported.

Note: It is understood that all hazardous waste, regardless of the form, is considered to be solid waste. Process waste is defined as waste generated as a result of an on-going process line or operations, excluding waste generated as a result of environmental restoration activities. Environmental management/restoration waste is defined as all waste other than process waste.

Process and environmental management/restoration wastes shall be differentiated in the data narrative, since management actions in responding to trends differ significantly depending on the type of waste and the maturity of the program.

Uncharacterized waste should be reported as environmental management/restoration Mixed Waste in the quarter during which it was generated. Since uncharacterized waste is not likely to be a product of ongoing process lines or operations, it should be considered environmental management waste. Based on discussions at the 1-Year-Review meeting, it should be categorized as mixed waste (consistent with general practice). If uncharacterized waste is subsequently' characterized as something other than mixed waste, it shall not be reported as generated a second time under the PI program, nor shall previously reported data be revised. Recategorization of significant amounts of waste shall be discussed in the PI report management summary.

Date Neededi $\quad$ PI 3.4.1 Radioactive Waste Generated.

PI 3.4.2 Hazardous Waste Generated.

PI 3.4.3 Mixed Waste Generated.

Units: cubic feet. 


\subsection{MANAGEMENT}

\subsection{DOE Audit Issues}

Purpose: The purpose of this indicator is to measure the responsiveness of management and staff to findings, concerns, and recommendations from oversight and line program assessments. This PI provides an indication of the management control and staff attitude toward improvements in the conduct of contractor activities and openness to suggestions of outside DOE organizations.

Definitien: The number of DOE audit issues open longer than 90 days at the end of the reporting period. Open issues are defined as DOE audit issues (including findings, concerns, recommendations, etc.) for which all associated contractor corrective actions have not been completed.

Notes: This PI includes ES\&H related issues identified by DOE or DOE-sponsored oversight assessments and line program self-assessments. All Tiger Team findings and ES\&H related security/quality assurance issues for which contractor corrective actions were identified are to be included. OSH noncompliances and contractor-identified audit issues are excluded.

Data Needed: PI 4.1 Number of issues open longer than 90 days.

Contractor total.

\subsection{External Oroanization Issues}

Purpose: The purpose of this indicator is to measure the responsiveness of management and staff to findings, concerns, and recommendations from external organizations. This PI provides an indication of the management control and staff attitude toward improvements in the conduct of contractor activities and openness to suggestions of external organizations.

Definition: The number of external organization issues open longer than 90 days at the end of the reporting period. Open issues are defined as external organization issues (including findings, concerns and recommendations) for which all associated contractor corrective actions have not been completed.

Notes: This PI includes ES\&H related issues identified by external organizations (e.g., Defense Nuclear Facility Safety Board, the National Academy of Sciences, EPA, state and local agencies). Issues identified by M\&O contractor corporate organizations are to be included. ES\&H related security/quality assurance issues for which contractor corrective actions were identified are to be included. OSH noncompliances are excluded.

Data Needed: Number of issues open longer than 90 days, contractor total. 


\subsection{OSH Nencomollance}

Purpose: The purpose of this indicator is to measure the responsiveness of management and staff to resolve identified occupational safety and health (OSH) concerns.

Definition: The number of OSH noncompliance items open longer than 90 days at the end of the reporting period. Open items are defined as $\mathrm{OSH}$ noncompliance items for which all associated contractor corrective actions have not been completed.

Netes: OSH noncompliance items to be counted are those identified by anyone, not just those identified during OSH inspections. This is considered consistent with OSH requirements. Noncompliance items are to be counted separately to reflect instances of noncompliance; instances identified by more than one organization will not duplicate existing open items.

Data Needed: PI 4.3 Number of items open longer than 90 days.

Contractor total.

\subsection{Correatlve Maintenance Backlog}

Purpose: The purpose of this indicator is to measure the effectiveness of the programs in place to ensure necessary and timely repairs are made to facility equipment. Maintaining a small backlog is an indication of management control and staff concern regarding the material and safety status of the facility. It is a measure of effective planning, scheduling, coordination, and materials management. Keeping long-standing deficiencies to a minimum enhances the ability to operate the facility and encourages facility personnel to report deficiencies.

Definltien: The percentage of open corrective maintenance work requests, including those requiring facility or process shutdown, that are greater than three months old at the end of the reporting period. Corrective maintenance may include minor modifications if performed under a corrective maintenance work request.

Notes: The definition of corrective maintenance is a s follows:

Corrective (Repair) Maintenance: The repair of failed or malfunctioning equipment, systern, or facility to restore the intended function or design condition. This maintenance does not result in a significant extension of the expected useful life.

The 90-day clock starts at the date of item identification.

Data Needed:

PI 4.4.1 Number of open items $>90$ days old.

PI 4.4.2 Total number of open items. 


\subsection{Preventlve Maintenance Overdue}

Purpose: The purpose of this indicator is to monitor progress in the administration and execution of facility preventive maintenance programs. A small percentage of preventive maintenance items overdue indicates a management and staff commitment to the preventive maintenance program and an ability to plan, schedule, and pertorm preventive maintenance tasks as programs require. A facility with a good preventive maintenance program should require less.emergency maintenance, which may be reflected in improved safety and reliability and more efficient operation.

Definition: The percentage of preventive maintenance items that were not completed within the original scheduled interval.

Notes: The definition of preventive maintenance is as follows:

Preventive Maintenance: All those systematically planned and scheduled actions performed for the purpose of preventing equipment, system, or facility failure.

In addition, it is the intent that, if a facility maintenance program is such that the scheduled time interval includes a grace period (i.e., $\pm 25 \%$ of the frequency of the maintenance), the item would not be considered overdue until the grace period has expired.

Date Needed: PI 4.5.1 Number of items not completed.

PI 4.5.2 Total items scheduled during the quarter.

\subsection{Occurrence Beports with Open Correctlve Actlons}

Purpese: The purpose of this indicator is to measure the commitment of DOE line program management and facility management and staft to taking timely corrective actions for improving facility operations and safety margins. This PI is an indication of safety culture of the facility personnel by demonstrating follow-up and applying lessons-learned from occurrences.

Defintilen: The siumber of Final Occurrence Reports for which all corrective actions have not been completed at the time of the quarter.

Date Needed: PI 4.6 Number of final reports with open corrective actions. 

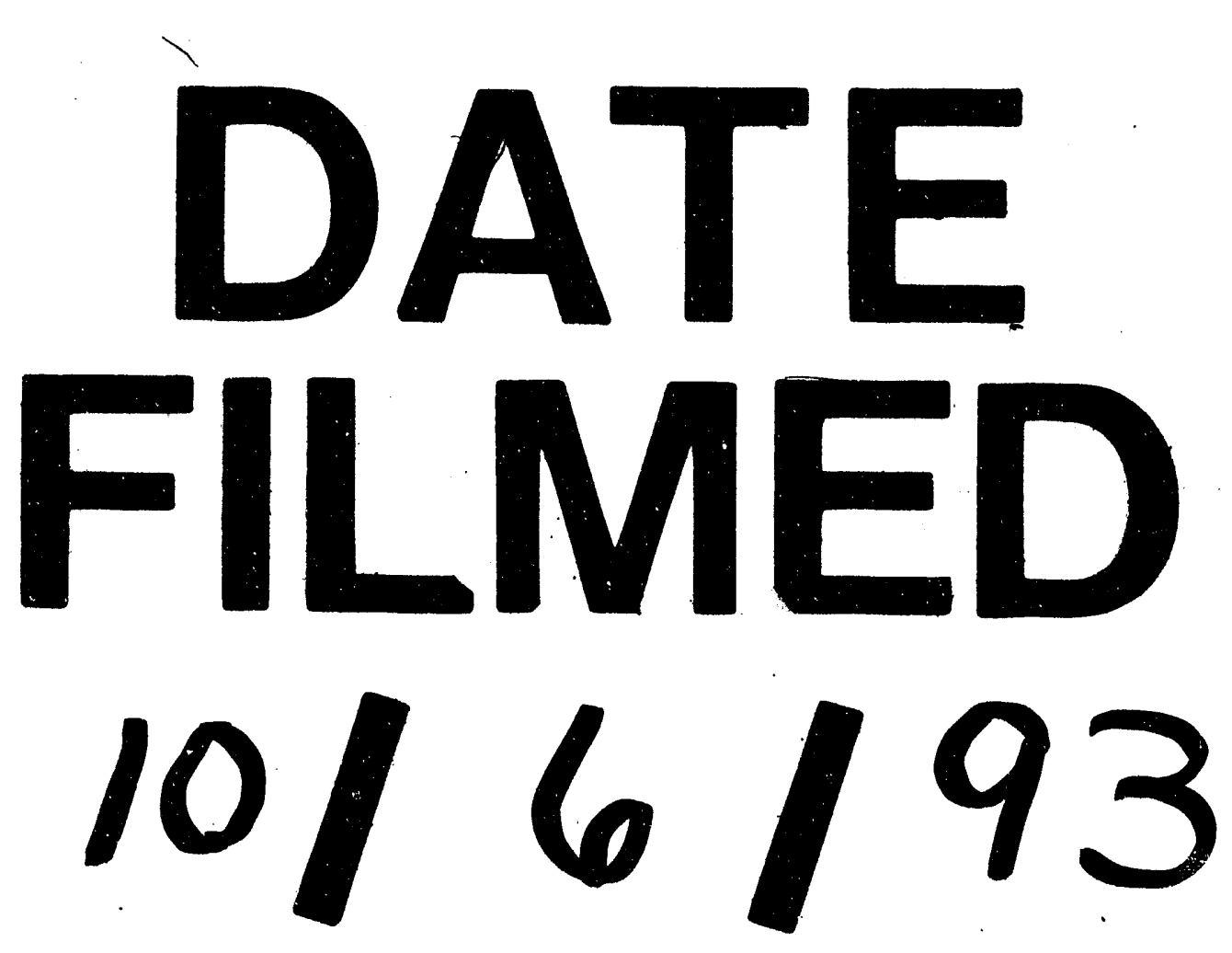
